University of Rhode Island

DigitalCommons@URI

Open Access Master's Theses

1979

\title{
PLANNER'S GUIDE TO COMMUNITY ENERGY CONSERVATION
}

William Ferguson

University of Rhode Island

Follow this and additional works at: https://digitalcommons.uri.edu/theses

\section{Recommended Citation}

Ferguson, William, "PLANNER'S GUIDE TO COMMUNITY ENERGY CONSERVATION" (1979). Open Access Master's Theses. Paper 481.

https://digitalcommons.uri.edu/theses/481

This Thesis is brought to you for free and open access by DigitalCommons@URI. It has been accepted for inclusion in Open Access Master's Theses by an authorized administrator of DigitalCommons@URI. For more information, please contact digitalcommons-group@uri.edu. 
PLANNER'S GUIDE TO COMMUNITY >

ENERGY CONSERVATION

$B Y$

WILLIAM FERGUSON

A RESEARCH PROJECT SUBMITTED IN PARTIAL FULFILLMENT

OF THE REQUIREMENTS FOR THE DEGREE OF MASTER OF COMMUNITY PLANNING

UNIVERSITY OF RHODE ISLAND

1979 
MASTER OF COMMUNITY PLANNING

RESEARCH PROJECT OF

WILLIAM FERGUSON

Approved:

Research Project Advisor) (u) Celle

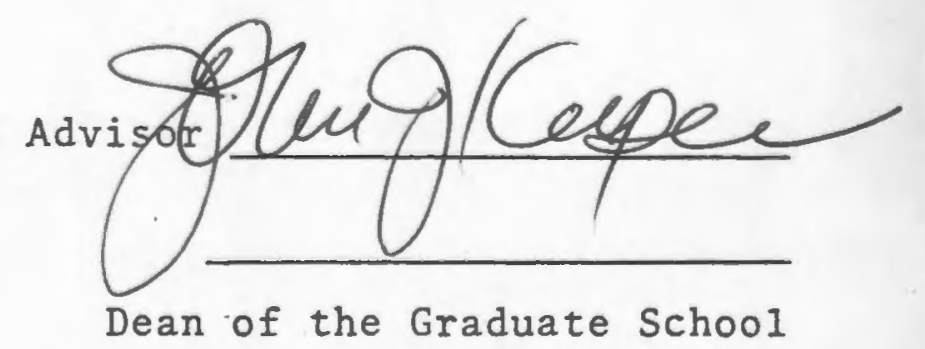

UNIVERSITY OF RHODE ISLAND

1979 


\begin{abstract}
This research paper examines the community planner's role in responding to this country's energy problem. The paper is based on the principle that because final use of energy is ubiquitous, relative to production of energy, that a solution to this problem can be best approached from the grass roots level. As a result, the paper focuses on reduction of energy use rather than other energy considerations. The paper establishes the correlation between physical growth and energy consumption, thereby placing the planner in a key role for energy planning due to his traditional function as manager of physical growth and physical resources. This paper suggests an approach to local energy planning by making it a part of the community master plan. It then proceeds to present facts, tools and implementation resources and mechanisms that can be used by the planner to achieve a more energy efficient community.
\end{abstract}


TABLE OF CONTENTS

CHAPTER I: THE NEED FOR COMMUNITY ENERGY ... page 1 PLANNING

- Introduction

-PROBLEM DEFINITION

-PURPOSE AND INTENT

CHAPTER II: AN APPROACH TO LOCAL ENERGY PLANNING

- Introduction

- LOCAL ENERGY PLANNING

AND THE MASTER PLAN

- COMMUNITY FUNCTIONS

- INTEGRATING ENERGY INTO

THE MASTER PLAN

CHAPTER III: ENERGY USE IN BUILDING AND BUILDINGS

- Introduction

- EMBODIED ENERGY

- ENERGY CONSUMPTION

IN BUILDINGS

- CONCLUSION

CHAPTER IV: ENERGY AND URBAN FORM

- Introduction

- SPATIAL CONSIDERATIONS

-SITE PLANNING AND

BUILDING DESIGN

- CONCLUSION

CHAPTER V: IMPLEMENTATION RESOURCES AND MECHANISMS

- Introduction

- RESOURCES

- MECHANISMS

- CONCLUSION 


\section{APPENDICES}

APPENDIX A

1. AN ORDINANCE PROHIBITING THE ISSUANCE OF PERMITS FOR THE INSTALLATION OF GAS BURNING APPLIANCES WITHIN THE CITY, DIRECTING THE CITY ADMINISTRATION TO APPLY TO THE PUBLIC UTILITIES COMMISSION FOR AUTHORITY TO DENY SUCH PERMITS IN THE UTILITY DEPARTMENT SERVICE AREA OUTSIDE THE CITY, AND DECLARING AN EMERGENCY

APPENDIX C

1. ENERGY INTENSITY (EI) IN STATE AND LOCAL PROCUREMENT FROM INDUSTRY ESTIMATED FOR 1980

2. 1975 ENERGY USE PER DOLLAR OF VALUE ADDED

3. 1975 PURCHASED ENERGY COSTS AS PERCENT OF VALUE ADDED

4. Outline of Census Bureau Energy Related Statistics

5. Industrial energy Assessment Survey

6. ENERGY EMBODIMENT PER UNIT OF MATERIAL

7. Energy Assessment Survey: Residential

8. Building Condition Survey

APPENDIX D

1. GENERAL HIGHWAY AND STREET STANDARDS

2. HIGHWAY CLASSIFICATION

3. Neighborhood Concept

4. Costs of Sprawl Representative Development Patterns 


\section{CHAPTER I}

\section{THE NEED FOR COMMUNITI ENERGY PLANNING}

\section{Introduction}

Beginning with the OPEC oil embargo of 1974 the idea that energy supplies are finite became acknowledged by a large number of Americans. This oil embargo precipitated a concern on the part of many individuals regarding the situation of ourselves and of our country with regard to our energy posture and energy availability. Cheap and available energy provided Americans with a high standard of living and helpedito make the United States the most powerful nation in the world. By comparison to today it seems there was very little regard for or acknowledgement of the importance of energy in the pre embargo era.

A rise in the price of energy is felt in many ways, as this resource is an input to everything we come into contact with in our everyday lives. Energy is a component to manufacturing and production, maintenance and construction, and transportation. It is an input to the house we wake up in the morning, to the breakfast we eat, and to the transportation we take to work. When considering such a pervasive resource it would seem that everyone could and should have a role in solving the energy problem. In a sense everyone created it. Everyone is subject to the implications of it.

Various policies and strategies relative to our energy situation have been posited by government officials, members 
of Congress, and other informed and responsible groups and individuals, including AIP. These have been reflected in programs and statements ${ }^{1}$ that have been promulgated and, in the case of programs, some are being implemented. Policies and strategies center around three broad needs or concerns which in sum, define our energy problem. These are: (1) the need to reduce our dependence on foreign/imported oil so as to remove this country from its precarious position regarding access to energy and its implications for national security, balance of trade, and foreign policy; (2) the need to maintain industrial and economic growth so as to continue to support the standard of living which Americans now enjoy relative to other countries and to ameliorate the effects of high energy costs on the socially disadvantaged; (3) the need to protect and preserve our environment in the face of continued demand for resource extraction, the construction of energy facilities, and the adoption of alternative energy resources. The strategies which have been developed in response to these needs fall under the categories of : petroleum reserve and fuel allocation, ${ }^{2}$ (2) increased domestic energy production primarily through the use of coal, 3 nuclear, and renewable energy resources, (3) energy conservation.

Congress has responded to these needs by employing the above strategies in six seperate pieces of energy legislation since 1974. ${ }^{4}$ The most significant piece of energy legislation to date is the five part National Energy Act which was passed by Congress and signed into $1 \mathrm{aw}$ by the President on 
November 9, 1978. Inclusive of this energy package are:

The National Energy Conservation Policy Act, which provides programs for attaining energy reductions in all end/use sectors; ${ }^{5}$ The Energy Tax Act, which provides incentives and disincentives designed to result in reductions in energy use and a shift from conventional petroleum fuels; ${ }^{6}$ The Powerplant and Industrial Fuel Use Act, which is intended to force utilities and industries to switch from the use of oil and natural gas to the use of other indigenous fuels, particularly coal; The Public Utilities Regulatory Policies Act, which seeks to ensure that'retail rate structures of utilities encourage conservation of energy, efficient use of facilities and resources, and equitable charges to consumers; and The Natural Gas Policy Act, which contains provisions for the phase out of price controls on this fuel type and sets forth fuel allocation guidelines. ${ }^{7}$ Acts passed prior to the National Energy Act laid much of the foundation upon which this five part energy package was ultimately built. Of particular importance in this regard and of particular pertinence to this paper is the Energy Policy and Conservation Act of 1975 which attempts to establish a basis for a comprehensive and concerted conservation ethic in this icountry. ${ }^{8}$

\section{PROBLEM DEFINITION}

The purpose of this paper is to provide the community planner with a guide to local energy planning. The need for energy planning at the local level is beginning to be recognized. The American Institute of Planners points to this need in Planning Policies 177, the AIP annual statement of 
policy. In highlighting pertinent sections of this statement the AIP states that:

1. "Comprehensive energy planning should take place at all levels of government. An energy element should be incorporated into regional, state and local comprehensive planning documents. This can aid in the formulation of policies concerning land use and physical development that are responsibe to the need for better management of our energy resources."

AIP further states that:

2. "States and local governments should develop plans patterned after the National Energy

Plan. The states and multijurisdictional substate organizations should provide technical assistance to local planning agencies, as necessary."

Several local communities have begun to undertake a com-r. prehensive conservation energy planning effort. The most notable examples are Sacramento California and Yamhill County Oregon. Sacramento is trying to undertake a program which will effect the entire region around the state capital. 10 The Sacramento plan seeks to reduce energy consumption by thirty percent while increasing jobs and polulation in the region. Yamhill County has developed a document entitled, "Relationships of Energy to Land Use", which guides the County's planning initiatives to ensure that energy is properly considered. ${ }^{11}$ other local communities have also undertaken less comprehensive energy planning efforts. ${ }^{12}$ These communities include Davis California, which is known for its innovative use of building codes and subdivision regulations; Hobbs New Mexico, which has employed the use of a management plan to mobilize and organize its human resources and Seattle, which has implemented several programs through its municipal 
utility, Seattle City Light. ${ }^{13}$ The communities that have undertaken the development and implementation of piecemeal plans vastly outnumber those which have undertaken partial plans. In view of this the goal of the AIP for comprehensive energy planning at the local level is probably a long way off and the practicality of undertaking a comprehensive energy planning effort on a local basis is most often very dubious.

The constraints to undertaking energy planning on the local level are probably most largely attributed to a lack of resources rather than a lack of interest on the part of the planner. ${ }^{14}$ Some other constraints include a lack of preparedness on the part of the planning profession to deal with the energy situation, a lack of understanding of the planner's role relative to the energy problem, ${ }^{15}$ a lack of adequate information to formulate an approach to community energy planning, lack of manpower, and lack of money. ${ }^{16}$ Another constraint is the question as to whether energy is an appropriate responsibility for the community to take on and commit resources to. 17

Most planners and most community officials probably would have difficulty committing themselves to this cause and in defending it as a community responsibility. This is particular1y difficult when comparing it to other vital community services which must be planned for and maintained and which are more traditional in nature such as education, public works, fire and police, and administration of the government. In a recently printed article one community planner defends undertaking energy planning with the following statements: 
"Conservation would create as many or more jobs as would be produced by constructing new thermal facilities to generate an equivalent amount of energy, and the jobs produced would be of particular benefit to unskilled labor.

It is six times less expensive to produce energy through conservation than through building new power plants.

Saving a portion of our dwindling fossil fuels for such non-energy purposes as lubricants and medicines will afford greater security for future generations." 18

There are other convincing reasons for undertaking local energy planning programs including the reduction of environmental residuals, ${ }^{19}$ reducing municipal budgets, improving housing stock, assisting the socially disadvantaged in the community, as as a show of support for undustry and business in the community. These concerns, coupled with the three areas of national concern outlined previously, provide many reasons for undertaking local energy planning which are consistent and compatable with community goals, other community programs, and provisions of the community master plan.

This paper will focus on energy conservation and is based on the principle that the final use aspect of the energy picture is.most suited to the community planner. There are significant reasons for arriving at this principle. The reasons are scale, scope and jurisdiction. Scale, scope, and jurisdiction are reasons for not addressing areas outside the realm of conservation in this paper. They are also reasons for addressing conservation.

In explanation, power production (for the most part) and petroleum reserve, the "other" strategies mentioned in the in- 
troduction, are large scale undertakings if they are to be developed in an economical manner. The scale required to make these facilities economically sound and reasonable put them beyond the capacity of local government needs in most cases. Related to the question of scale is scope. Energy supply and production necessarily have regional implications. Energy is a commodity which is isolated in supply and ubiquitous in demand. $0 i 1$ is the most extreme example of this with the United States having to go outside the country for fifty percent of its petroleum supply. ${ }^{20}$ This is also true with regard to our elecricity supply where large scale production and pooling of power has been determined to be the most efficient, economical,. and reliable way to produce power. ${ }^{21}$ This thinking is illustrated by the fact that General Electric Company currently has orders for twenty nuclear generating units rated at 1360 Mega Watts, each capable of providing the electric needs of over a million people (approximately the population of Rhode Island). 22

When considering energy conservation the scale and scope of undertaking programs to implement these strategies are appropriate to the capabilities of local government. Because energy consumption is ubiquitous and is a function of each final user the scale of programs only have to be extensive enough to meet the needs of the typical end user in a given end use sector. Their scope need only be as wide as a given end use sector which is contained within the geographical area of the community. To clarify, this explanation is provided. In implementing a conservation program in the res- 
idential end use sector for example a program which can address the needs of each housing type in a cost effective manner can be successful in the remaining houses in the universe. Additionally, the scope of such a program can be limited by defining the universe geographically as a sub unit of the community and spill overs outside of the target area can be limited. Careful definitions of end use sectors and accurate assessment of needs will result in the most valid plans and effective programs. This requires the application of energy planning tools and understanding of energy considerations which are addressed in later chapters.

Jurisdiction is the final reason mentioned for "arriving at the principle which is behind the decision to center upon conservation in this paper. Mostly due to the regional scope of energy production/supply and petroleum reserve as well as the macro economics and national security implications of these strategies, regulatory authority and implementation resources lie at the state and federal levels of government. The National Energy Act provisions, which were briefly described previously, is typical of previous legislation which has placed program resources and jurisdiction, in virtually all instances, in the hands of federal and state government. Up to now this placement of programs in the state and federal levels of government is also true of energy conservation. Our most widely known and significant programs are delivered by state and federal government. These programs include tax credits, 23 utility conservation programs, home retro fit loans, school and hospital energy conservation pro- 
grams, loan guarantees, thermal efficiency standards for new construction, contigency gas tax, $55 \mathrm{mph}$ speed limit and mandatory automobile efficiency standards. Eight other conservation programs have been developed in all fifty states of this country to make them eligible for federal monies for implementation. These programs were provided for by the Energy Production and Conservation Act of 1975, and its amendments, 24 and requires states to; adopt thermal efficiency standards for all new construction, ${ }^{25}$ establish and promulgate lighting efficiency standards for new and existing public buildings, establish energy efficient procurement procedures in state and local government, establish programs which promote the use of public transit, enact a law which allows traffic to make a right turn at a red light, establish programs to create public awareness of the savings which are likely to result from undertaking specific measures and information on how to go about undertaking those measures, establish procedures for ensuring that effective coordination exists among local, state, and federal conservation programs within a state, and estab:lish programs for encouraging and carrying out energy audits in at least one of twelve building types and in at least one political subdivision in the state. Another program which should not be left unmentioned is the low income weatherization assistance program which is run by regional agencies (sub state) and are in force in all fifty states.

The short track record of some of these programs reveal that they have not been as effective in practice as they appear they should be in concept. ${ }^{26}$ Several of these are types 
of programs which lend themselves to implementation at the local level and include public awareness programs, code establishment and enforcement programs, and programs aimed at the building sector. The intent of this writing is not to say that these programs have been a wasted effort but to suggest that they have laid a useful framework from which to follow through to more effective implementation through a local approach in conjunction with the introduction of other programs.

A final reason for focusing on energy conservation as opposed to the other possible areas is that this subject matter is pertinent to all communities. Although the local plan-" ner is expected to have a role in things such as resources extraction, facility siting, and dealing with the impacts of energy related projects on the community, 27 these problems confront a minority of local planners. Additionally, the planing profession is equipped to deal with these considerations with existing tools which are traditional to his trade.

\section{PURPOSE AND INTENT}

As previously stated, the purpose of this paper is to provide the community planner with a guide to local energy planing. This document contains facts, strategies, and considerations to assist the community planner in developing a local energy plan and program. It is intended that this document be employed to eliminate some of the problems and constraints that confront the planner and the planning profession and provide ideas and information that can be employed to solve energy problems from the local level of government. 
The following four chapters address the multitude of considerations for the development and implementation of a comprehensive community energy plan. Chapter two of this document establishes the basis for local energy planning by identifying an approach which draws upon the traditional authorities, tools, and implementation mechanism of the community and the community planner. It illustrates how a local energy plan and program can and must be rooted within these traditional areas for an endeavor to be a success. Chapters three and four present data, data collection tools, and planning considerations to assist the planner in understanding the energy profile of the community and to apply in the formulation of policies goals, objectives, and plans. Chapter three addresses energy for production, construction, and buildings in this regard. Chapter four addresses energy and land use. Finally, Chapter five presents resources and mechanisms for implementation and demonstrates how information presented in the previous chapters can be applied towards implementation. In closing this chapter, although the information presented in this document should ideally be applied in the development of a comprehensive energy plan, earlier discussion in this chapter concedes that most often constraints make this impossible. In view of these constraints, this document is development more as a guide than a recipe or formula and is well suited to application in the development of modified plans or most preferably integrated into the community master plan. The remainder of this ducument will bear this out to the reader. 


\title{
CHAPTER 1
}

\author{
Footnotes
}

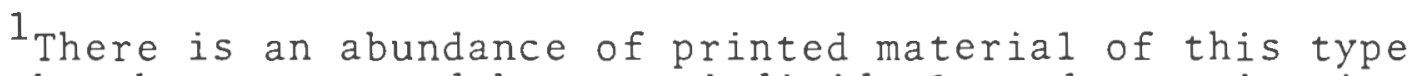
that has been prepared by many individuals and organizations. There are three particular writings in print that are of particular pertinence to this study. The are: American Institute of Planners, Planning Policies 177, (Washington, D.C., 1977 ), pp. 11,12; "New Orleans APA Workshops: How Do You Plan Local Energy", The Energy Planning Report, 3 (Oct. 6, 1978): pp. 6,7; Jeff Forker, "Viewpoint: Will the Real Energy Problem Please Stand Up", Energy Management, ed. Jeff Forker, (Fal1 1978 10-13.

${ }^{2}$ Two acts are of particular significance with relation to petroleum reserve and fuel allocation. The Energy Policy and Conservation Act of 1975 provides for the establishment of a "Strategic Petroleum Reserve" by $12 / 78$ which will contain a reserve of energy suitable to fill this countries energy needs for three months. The Fuel Allocation Act of 1974 .

${ }^{3}$ The Energy Supply and Environmental Coordination Act calls for the conversion of petroleum burning industrial and power plants to coal. The Power Plant and Industrial Fuel Use Act of 1978 reiterates this and expands its scope.

${ }^{4}$ These acts are 1 isted as follows:

The Fuel Allocation Act of 1974, The Energy Supply and Environmental Coordination Act of 1974, The Solar Heating and Cooling Demonstration Act of 1974, The Energy Policy and Conservation Act of 1975, The Energy Conservation and Production Act of 1976, and the five part National Energy Act.

${ }^{5}$ An end use sector is a well defined segment of the economy which consumes energy as a final product. An end use sector could be the buildings sector. Or it could be types of buildings; new, old, residential, commercial, public, and industrial. Or it could be uses within buildings; lighting, heating, appliances and air conditioning.

${ }^{6}$ This Act addresses the residential, business, and transportation end use sectors. Income tax credits are provided to homeowners who purchase energy conservation or solar energy equipment. Businesses are provided with a 10 percent investment tax credit for installing energy conservation equipment. The transportation tax is a tax on gas guzzler cars which imposes gradually higher taxes on less efficient cars.

${ }^{7}$ Several good summaries of the National Energy Act have been developed. The New England Regional Commission developed a lengthy summary with editorial note addressing the ef- 
fects on New England, the U.S. Department of Energy has developed an uneditorialized summary, the National Governor's Association has developed a very succicnt editorialized summary. These summaries can be obtained by contacting the respective agencies: New England Regional Commission, 53 State Street, Boston MA: National Governor's Association, Hall of the States, 444 North Capitol St., Washington, D.C.

${ }^{8}$ Title III, Part C, section 361 of this act provides for the development of State Energy Conservation Plans with the goal of reducing energy consumption in the state by five percent. The Act authorizes 150 million dollars to make available to states for the development and implementation of plans that have been approved by the U.S. Department of Energy. The Energy Production and Conservation Act is also the first piece of legislation to address energy in a comprehensive manner by covering production, conservation, petroleum reserve, pricing, and planning and management data aquisition.

\section{${ }^{9}$ American Institute of Planners, Planning Policies 177,} (Washington, D.C.) pp. 1112.

${ }^{10}$ Dennis Dickman and Lee Stephen Windheim, "Saçramento Can Do More With A Lot Less Energy", Planning, vol. 43 no. 11 (Dec. 1977) pp. 24,25.

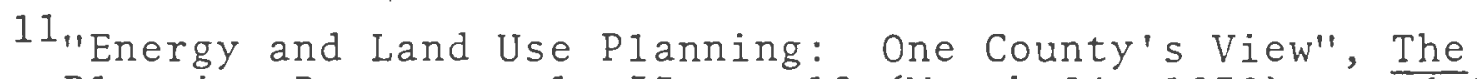
Energy Planning Report, vol. II no. 12 (March 24, 1978) pp. 6-8.

12 Robert Cassidy, "A Few Cities Aren't Waiting For The Next Energy Crisis", Planning, vol. 43 no. 11 (February 1977): pp. 24,25 .

13 Robin C. Calhoun andSam R. Sperry, "Seattle's Energy 1990 Program Conservation Today and for the Future", Technology for Energy Conservation, Information Transfer Inc. (Rockvilie Maryland), pp. 25-36.

${ }^{14} \mathrm{~A}$ number of articles in planning publications in recent years demonstrates the interest of the planner in local energy planning. See, Comer L. Taylor Jr., "Planning and Energy Conservation", Practicing Planner, vol. 8, no. 2, (June 1978), pp. $6-7$.

15 Edgar A. Imhoff, "Planners Can Improve Responsiveness to Surface Mining Reclamation Issues", Practicing Planner, vol. VI, no. 2, (Sept. 1974), pp. 20-22.

${ }^{16}$ For more discussion of these points see, Robert Cassidy, "A Few Cities Aren't Waiting For The Next Energy Crisis", Planning, vol. 43 no. 11 (Feb. 1977) pp. 24,25.

${ }^{17}$ In the Fall of 1978 the American Institute of Planners met in New Orleans for a three day workshop on "Community 
Energy Planning-Defining Achievable Alternatives". During this workshop all of the issues mentioned in this paragraph were discussed. A summary of the highlights of this workshop can be found in, "New Orleans APA Workshops: How Do You Plan Local Energy". The Energy Planning Report, ed. David L. Howe11, vol. II, no 12, (March 24 1978): pp. 6,7.

${ }^{18}$ Energy and Land Use Planning: One County's View", The Energy Planning Report, ed. David L. Howell, vol. II, no $\overline{12}$, (March 24 1978): pp 6,7.

${ }^{19}$ The Office of State And Local Programs, Office of Energy Conservation and Environment, Federal Energy Administration, "Final Assessment of the Environmental Impacts of the State Energy Conservation Program", April 1976.

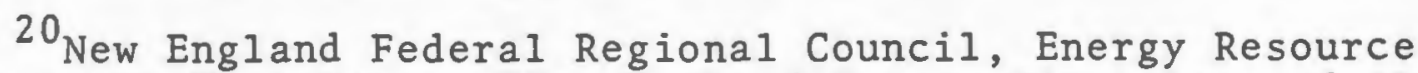
Development Task Force, "New England Energy Situation and Alternatives for 1985", (August 1977): p. 12 .

${ }^{21}$ New England Regional Commission, New England Power Pool: Description, Analysis, Implications, Energy Program rechnical Report: 76-2 (March 1976): pp. 3-1 3-8.

${ }^{22}$ To further illustrate this point, only two states in New England generate all their own power. These two states, Massachusetts and Connecticut, produce a surplus which it makes available to other New England States through the New England Power Pool. Rhode Island is very dependent on this power pool, generating only about 10 percent of the power it consumes within the state. Also, the evolution of the size of generators in power production is discussed in, "Generation: From the Curtis Turbine to Combined-Cycle Configurations", Electric Forum vol. 4 no. 3, ed. D.E. Wilcock, pp. 6-10.

${ }^{23}$ See Appendix A for a brief description of the programs listed in this paragraph and the following paragraph.

${ }^{24}$ Title IV, Part B, section 432 makes a major amendment to the State Energy Conservation Plan program originally provided under the Energy Policy and Conservation Act of 1975 .

25 There are two provisions in seperate pieces of legislation which address thermal efficiency standards for new construction. A provision in the Energy Policy and Conservation Act of 1975 makes statewide adoption of an acceptable standard a prerequisite for funding of State Energy Conservation Plans under section 362 of that act. Title III of the Energy Conservation and Production Act of 1976 provides for the development of standards by HUD and once developed this or an equivalent standard will have to be adopted for an entity to be eligible for any HUD funds.

${ }^{26}$ States that have received funding under Title III of the 
Energy Policy and Conservation Act of 1975 are required to make annual BTU assessments of progress of the state towards their energy conservation goal. The most recent assessments for calendar year 1978, show that most states are lagging behind.

${ }^{27}$ For more information on energy project impacts see, U.S. Department of Housing and Urban Development, Office of Community Planning and Development, Rapid Growth from Energy Projects: Ideas for State and Local Action, (March 1976). 


\section{West German City Planners Exper With a Community Set Up to Save En.}

By BiLl Paúl

Staff Reporter of THE WALL STREET JoURNAL

ERLANGEN, West Germany-When it's built, probably within the next two years, the new suburb of this squthern German city will look like any other residential community.

But there will be an important difference. Part of the suburb will have been designed and bullt specifically to save energy-the first "energy-planned" community in the world. U.S. energy officials will be among the interested observers.

What is an eneroy-planned community? It's a community where home owmers must abide by tough city ordinances on positioning of homes for maximum exposure to the sun. It's a community where homeowners must plant tall shrubbery to lessen the coolIng effects of the wind and must heat their homes in officially prescribed ways, using nonoil energy sources.

In exchange for abiding by these and other rules, homeowners will save $20 \%$ or more on their annual home-heating bills. At least that's the estimate of researchers at Battelle Institute of Frankfurt, an economics and environmental research organization that designed the community.

\section{A Sufficient Sample}

Nothing in the Battelle plan represents new technology. Rather, Battelle took many simple energy-saving ideas, such as utilizing solar power, and incorporated them into a town plan that has the legal backing of the local authorities. Erlangen officials are betting that people won't mind conforming to a more stringent building code if it means a substantial energy saving.

To be sure, Erlangen officials aren't certain that people will want to live in the energy-saving development. Thus, despite finan cial assistance from Bonn, they are settlng aside only a small part of the privately developed suburb for the project. About 1,000 people of the 15,000 eventually expected to live in the community will reside in the en. ergy-saving section.

Still, officials in Bonn think that will be a sufficient sample to indicate whether energy saving can be carried out through town planning. (Houses in the test area probably won't go on sale to the public for several more months.)

\section{Every Tree and Bush}

The Erlangen project is part of a four-nation study on energy saving under the auspices of the Intemational Energy Agency, a Paris-based intergovernmental body that promotes ways to reduce dependence on oil. Other countries taking part are the U.S., Greece and Italy. Greece and Italy are focusing on energy saving in rural areas, while the U.S., like Germany, is working on urban energy planning. *

An official of the U.S. Department of Energy says the department hopes to turn the

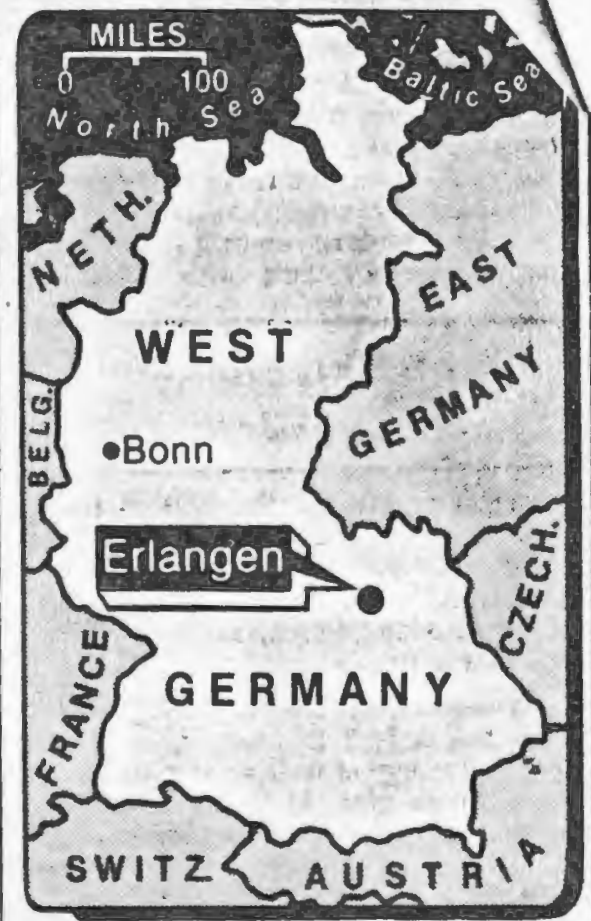

South Bronx area of New York City into another Erlangen, the only difference being that the strict energy-saving rules would be applied to offices and factories instead of homes.

But the South Bronx and other U.S. projects are farther off than the Erlangen project, which already has been planned down to the location of every tree and bush.

Among the features of the community is a system incorporating a variety of homeheating methods. Individual homes far away from the gas line will use heat pumps that can be driven either by solar power or by electricity. Battelle researchers say that if a homeowner installs solar panels on his roof, the heat pump will run on solar power most of the time, saving as much as $50 \%$ on the annual heating bill.

For homes nearer the gas line, gas alone will be used.

Waste water from a local power station will heat muttifamily dwellings.

Battelle estimates that planting trees and bushes in the proper places throughout the community can cut the average homeowner's heating bill $5 \%$ a year by reducing the cooling effect of wind currents, especially in winter. Homeowners must plant the bushes; the city will plant the trees.

The Battelle plan aiso dictates the maximum height of homes and multifamily dwellings according to location. Battelle worked all this out on a machine called a hellograph, which simulates the position of the sun on the community in any month. By using the hellograph, the researchers were able to locate buildings so as to prevent one from carting a shadow on another. 


\section{outrace town's ability to plan for them}

\section{- By LARRY BRUNELI SowneBalleth Staff Witte}

NORTH ATTLEBORO, Mass. - Town Department heads, who had to estimate next year's gasoline budget about five months ago, may find themselves asking the Finance Committee for more money before the end of fiscal 1980.

The cost of premiun gasoline, which was 56.8 cents a gallon last November, when most budgets were being prepared, has now risen to 67.8 cents. Three weeks ago the cost of the premium gasoline, which is used in most of the town vehicles, was 61.1 cents.

Town vehicles using unleaded gasoline, which includes about 25 from eight lown departments including 13 police cars, are being filled at a cost of about 64 cents a gallon. On March 27, the price of a gallon of unleaded gasoline was 60.54 cents. On March 21, 1978, the town paid 47.14 cents a gallon for unleaded gasoline.

"I just can't imagine that they (the department heads) would have put in for such drastic increases," Selettman John Drury said. "I would expect they'd put in for some, but I don't know if they put in for this much."

DRURY SAID HE EXPECTS that by this time next year, some officials may have to ask the Finance Committee for a reserve fund transfer to cover the steadily in creasing cost of gasoline.

James McKeon, a member of the Board of Public Works and the former highway superintendent, also thinks that some town departments might not have allowed enough money to meet their gasoline needs.

"ft's tough, you just can't figure it anymore." McKeon said. "You can say I'll figure on 80 cents a gallon and by the end of the year. it's 85."

"We're going to try to start conserving as much gasoline as possible," he said "but you can't put all the trucks in the garage."

Police Chief John D. Coyle Jr", whose department is the largest consumer of gasoline, says he is concerned not only with the rising cost of gasoline but also the allocations.

A spokesman for the Texaco Co., the town's gasoline distributor, said he recently received the town's new monthly gasoline requests. He said the departments would receive 85 percent of these new figures.

$$
\text { - },-\bullet
$$

HE SAID HE DD NOT KNOW how much gasoline the police department ordered last year but added that its new requirements average about 5,200 gallons a month.

1. - noid nrins tn rerpiving the new gasoline require 


\section{CHAPTER I I \\ AN APPROACH TO LOCAL ENERGY PLANNING}

Introduction

A local energy plan should have its beginnings in and derive its basis from functions, tools and authorities that are already within the repertoire of the planner. Much can be done to initiate the adoption of energy considerations on the local level because energy considerations permeate every community function. Phased and incremental adoption and introduction of energy considerations into master plans can test the community reaction to energy involvement and serve as a useful trial baloon to the adoption of more specific and meaningful energy planning.

Identification of those community functions which most lend themselves to intervention on the part of the planner should be the first step when considering an energy program. Having a broad understanding of how these functions relate to energy is part and parcel to this first step. These considerations set the tone for this chapter. This chapter seeks to set out the framework for approaching energy planning. It sets out this framework in a broad and comprehensive manner with an eye toward total integration into a community master plan. However it also attempts to establish a universally valid approach from which communities can pluck selected portions to establish an energy program on an incremental basis without loosing site of the comprehensive context from whence it came. 


\section{LOCAL ENERGY PLANNING AND THE MASTER PLAN}

The comprehensive plan has been defined by the planning profession as, "an official public document adopted by a local government as a policy guide to decisions about the physical development of the community". 1 Further definition and explanation of the comprehensive plan depicts it as:

1. consisting of three technical elements; the private uses of land, community facilities, and circulation.

2. being comprehensive in scope, long range, general, focusing on physical development, relating physical design proposals to community goals and social and economic policies, primarily a policy instrument and and secondarily a technical instrument.

3. functioning to facilitate policy formulation. and effectuation by legislative bodies and chief executives establish communication and coordination among government agencies, provide a forum for conveying advice from the government technicians to the policy formulators, educate the public about community issues and conditions, solicit public viewpoints, provide government agencies with a context into which each one can place its own plans and programs.

4. a process which requires continual review and appraisal and from which benefits flow rather than an end in itself. It depends upon carefully drafted programs, zoning ordinances, budgets, and capital investment programs for its implementation and the collection and review of technical data for its development. 2

Recognizing the distinction between the plan, planning tools, and implementation is important to the planner and to the reader of this document. These are concepts which have historically been confused and used synonamously when in fact they are very distinct. These are three seperate concepts which together make up the planning process and are addressed in seperate chapters in this document. This chapter, Chapter II, addresses the plan. Chapter III and IV address the tools, 
Chapter $V$ addresses implementation.

Energy components can be integrated into the comprehensive plan to meet specific energy goals and/or as a means of attaining related community goals. Establishing provisions for energy in the plan which are consistent with and contribute towards the attainment of other goals of the community may be the best way to assure that progress is made in ultimately effectuating policies and plans for energy. For example, this has become a recommended course of action within the 208 program. 4208 is a federal program aimed at reduction of water pollution and bringing water bodies and waterways up to fishable and swimmable levels by 1983. The success of the program is to a great extent dependent on performance at the local level. One 208 expert advocates that, "One way to almost assure local implementation of 208 is to show how it can accomplish some of the existing desires of the community". "This will help planners to build the coalition necessary to implement 208. The same can be said for energy, with master planning advocated as the best mechanism from which to begin the building of this coalition.

The traditional focus of comprehensive planning on private uses of land, community facilities, and circulation are clearly the appropriate areas for which to link energy planning. The level and type of energy consumption is clearly a function of the physical size and make up of the community. Like any other resource which is consumed in the community it has its social and economic implications. Whether the goals of the community are explicitly energy goals or not, the form- 


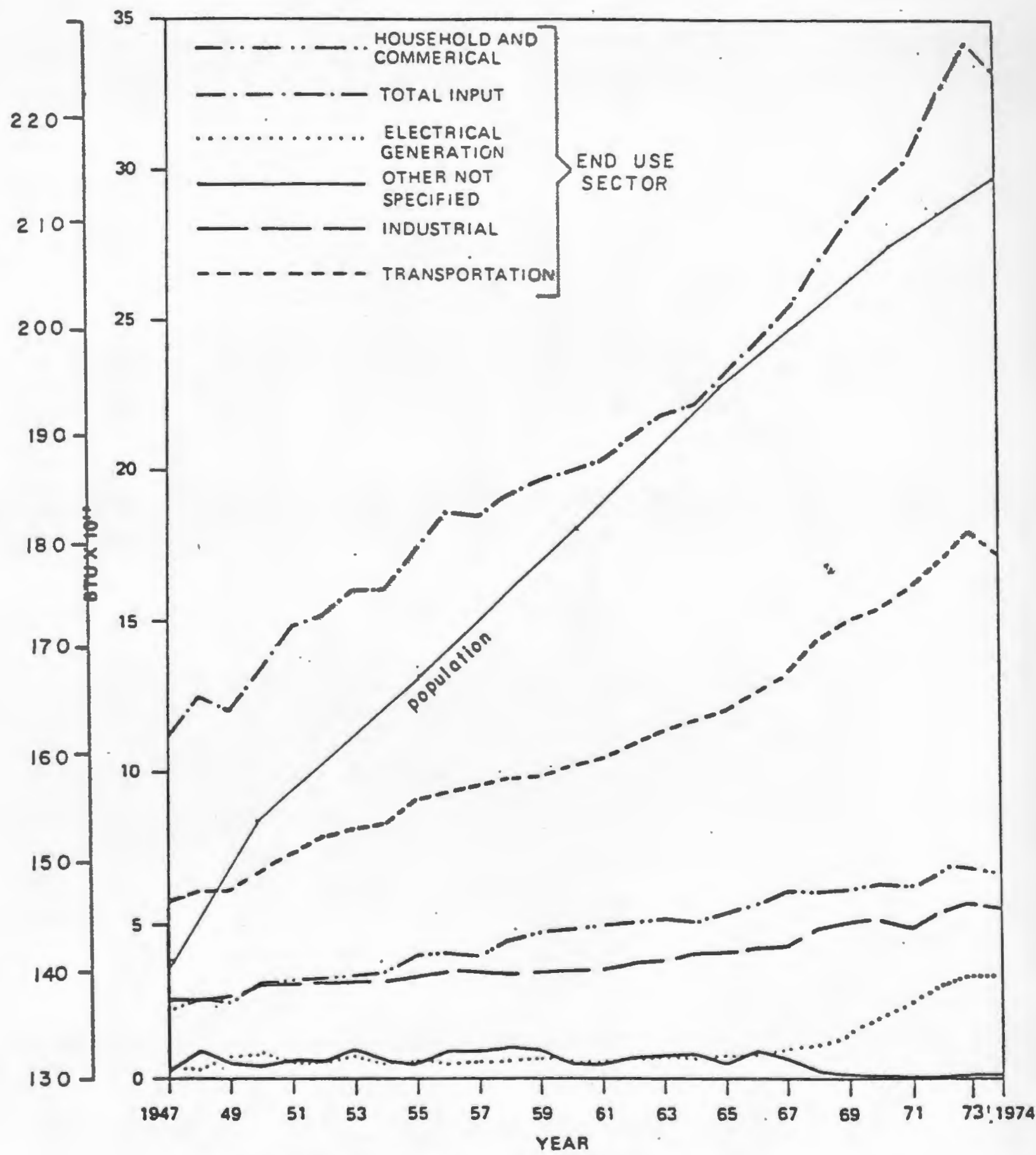

I1Eare II-1 Petroleum Consumption by Sector, 1947-1974

U. S. POPULATION, 1947-1974

source:U.S. Department of Comerce, Bureau of the Census, Current Population Reports: Population Estimates and Projections, Series P-25, No. 704, washington, D.C. Jan. I977.Table D; U.S. Dept. of Interior, U.S. Energy through the Year 2000, Dec. 1972, tables 2, 6a, 6b. 


\begin{tabular}{lcc}
\multicolumn{2}{c}{ SECTOR END-USE OF ENERGY - 1974} \\
& $\frac{\text { New England }}{258}$ & $\frac{\text { United States }}{188}$ \\
Residential & 278 & 148 \\
Commercial & 138 & 358 \\
Industrial & 358 & 328 \\
Transportation & - & 18 \\
Agriculture & &
\end{tabular}

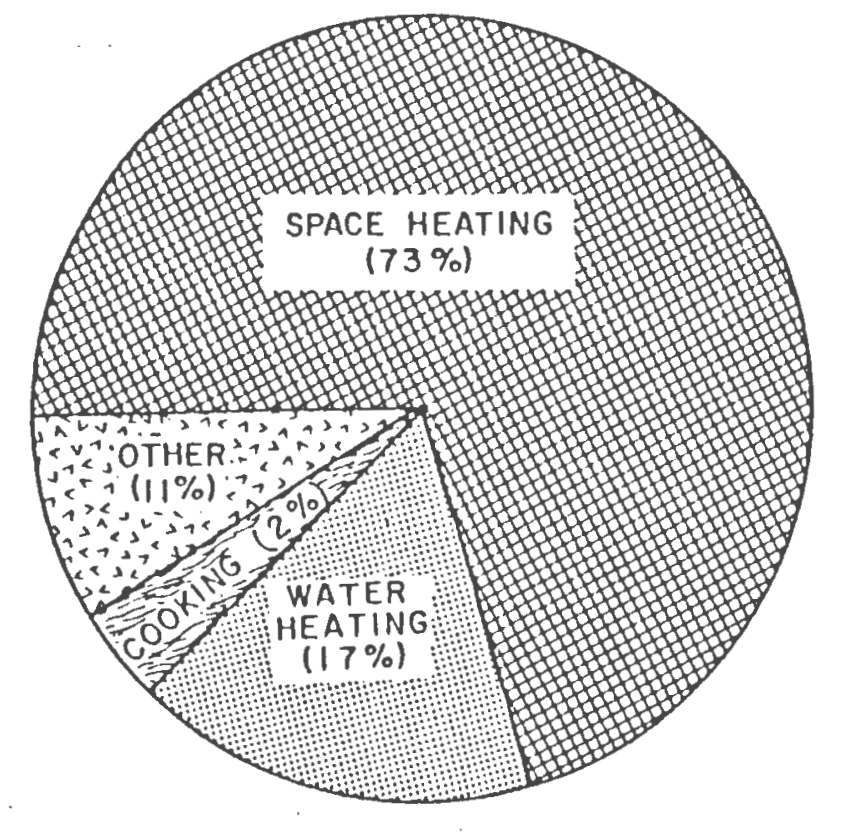

Residential and commercial energy use in the Northeast, 1972.

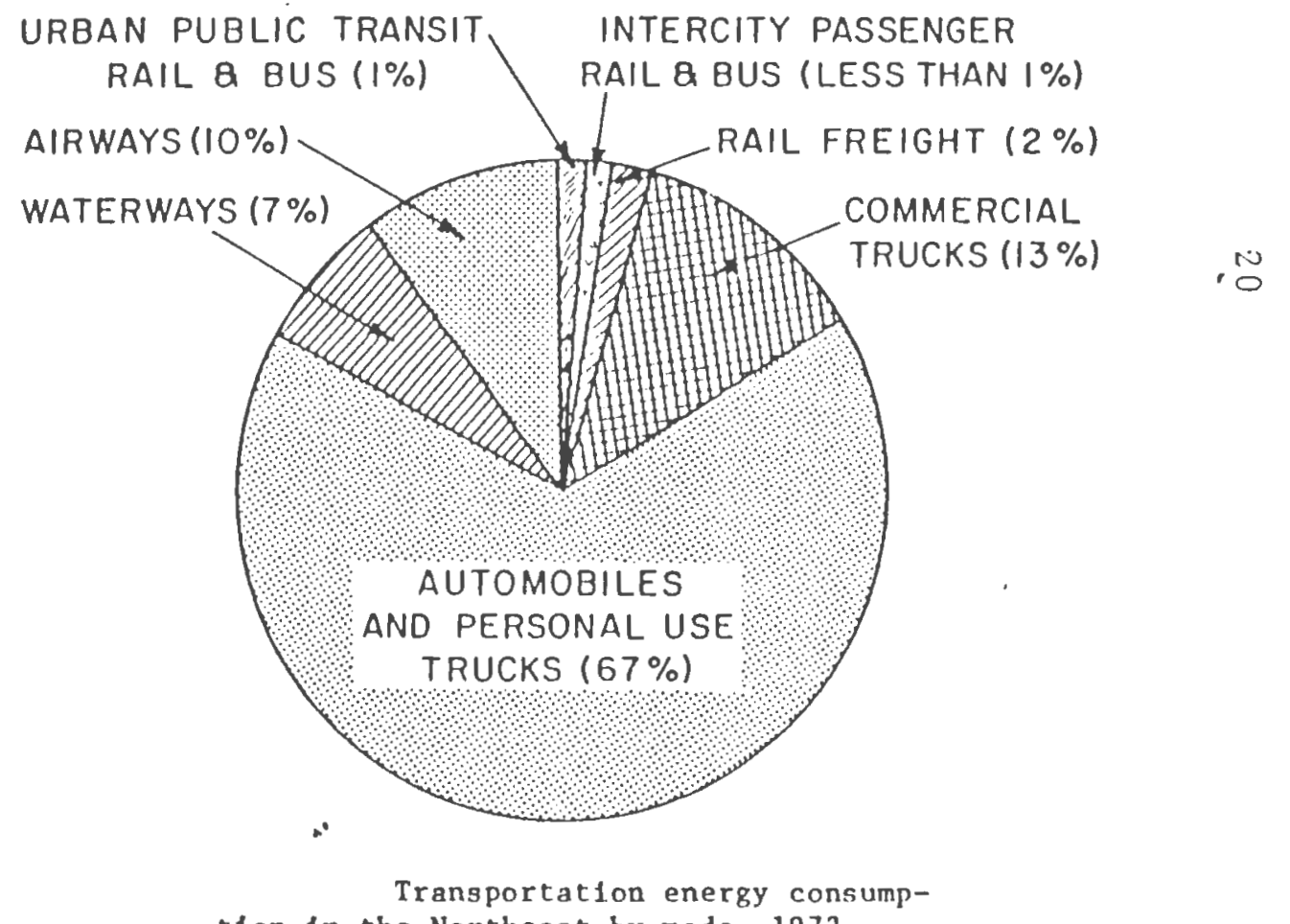

t1on In the Northesat by mode, 1972. 
ulation of energy policies and objectives can be done to enhance the probability of achieving these goals.

Figure II-1 is offered to illustrate how physical growth necessarily means an increase in energy consumption. The functions, or aspects, of the community which comprise its physical make up are presented subsequantly.

\section{COMMUNITY FUNCTIONS}

Identification of those functions of the community which most lend themselves to intervention on the part of the planner is important because it provides the planner with a perspective as to what extent he can influence the direction of the community's growth and, therefore, the way energy is usèd. By examining the community functions, establishing what individuals have a role, and establishing its relationship to energy, the planner can better assess what his role should be and how particular community functions fit into the overall scheme of community energy planning. This will help the planner in a number of ways It will help him to establish a coalition of support, it will help him in making an early identification of barriers to implementation (political, financial, bureaucratic barriers), it will help identify areas where a vacuum in planning or responsibility exists which he may be able to influence, and it will provide him with a framework of ideas to consider for integration into the master plan.

Table II-1 presents the typical functions of the community and important characteristics of each function. This matrix is a tool which can be applied by the planner in doing preliminary analysis of any community. The community functions 


\begin{tabular}{|c|c|c|c|}
\hline \multirow[b]{2}{*}{ FUNCTIONS } & \multicolumn{2}{|c|}{ PRESENT LOOKING FUNCTIONS } & \multirow[b]{2}{*}{$\begin{array}{l}\text { IMPLEMENTATION } \\
\text { FUNDING SOURCES }\end{array}$} \\
\hline & $\begin{array}{l}\text { IMPLEMENTATION } \\
\text { MECHANISMS }\end{array}$ & nCTORS & \\
\hline $\begin{array}{l}\text { malntenance of housing } \\
\text { stock }\end{array}$ & minlmum housing code & $\begin{array}{l}\text { housing inspector, hous- } \\
\text { ing authority, landlords }\end{array}$ & $\begin{array}{l}\text { private, HUD, EDA, CSA, DOE, } \\
\text { state and local revenues }\end{array}$ \\
\hline $\begin{array}{l}\text { maintenance of govern- } \\
\text { ment bulldings }\end{array}$ & $\begin{array}{l}\text { budget, capital improve- } \\
\text { ments program }\end{array}$ & $\begin{array}{l}\text { department heads, build- } \\
\text { ing authority, chief exed }\end{array}$ & $\begin{array}{l}\text { local and state revenues, } \\
\text { HuD, EDA }\end{array}$ \\
\hline $\begin{array}{l}\text { matntenance of economic. } \\
\text { base }\end{array}$ & taxation & $\begin{array}{l}\text { chief exec. economic } \\
\text { development department }\end{array}$ & $\begin{array}{l}\text { private, Eon,llud, state } \\
\text { and local revenues }\end{array}$ \\
\hline $\begin{array}{l}\text { public transit and high- } \\
\text { way malntenance }\end{array}$ & $\begin{array}{l}\text { budget, pricing, regula- } \\
\text { tory powers }\end{array}$ & $\begin{array}{l}\text { public works dept...city } \\
\text { englneer, transit auth. }\end{array}$ & $\begin{array}{l}\text { HUD, EDA, DOT, UMTA, state } \\
\text { and local revenues }\end{array}$ \\
\hline $\begin{array}{l}\text { maintenance of pubilc } \\
\text { utilities }\end{array}$ & $\begin{array}{l}\text { budget, pricling, regula- } \\
\text { tory powers }\end{array}$ & $\begin{array}{l}\text { public works dept., ut ll } \\
\text { lty. commission, chicf ex. }\end{array}$ & utility revenues, taxes \\
\hline waste disposal & $\begin{array}{l}\text { budget, capital 1mprove- } \\
\text { ments program, pricing }\end{array}$ & public works dept. & $\begin{array}{l}\text { fees, local ancl state } \\
\text { revenues }\end{array}$ \\
\hline & FUTURE LOOKI & NG FUNCTIONS & \\
\hline $\begin{array}{l}\text { future use of vacant } \\
\text { land }\end{array}$ & land use plan, zoning & $\begin{array}{l}\text { planner, planning ba. } \\
\text { cons, com., Ind.dev. auth. }\end{array}$ & $\begin{array}{l}\text { private, BOR, BLM, HUD, } \\
\text { foundations }\end{array}$ \\
\hline site design & subdivision regulations & $\begin{array}{l}\text { planner,building Insp., } \\
\text { city eng., health dept. }\end{array}$ & local,private \\
\hline new construction & bullding code & $\begin{array}{l}\text { planner, blag. insp., } \\
\text { planning bd. }\end{array}$ & local,private, HUD,EDA \\
\hline $\begin{array}{l}\text { transportation and } \\
\text { highways }\end{array}$ & $\begin{array}{l}\text { land use plan, subdivi- } \\
\text { slon regulalons, }\end{array}$ & $\begin{array}{l}\text { planner, city enginecr, } \\
\text { planning bd. }\end{array}$ & $\begin{array}{l}\text { IMTA, FHWn, local and } \\
\text { state revenues }\end{array}$ \\
\hline municipal facilities & $\begin{array}{l}\text { land use plan, capital } \\
\text { lmprovements program }\end{array}$ & $\begin{array}{l}\text { planner, dept. heads, } \\
\text { chicf exec. }\end{array}$ & $\begin{array}{l}\text { local and state rever } \\
\text { EDA, llud }\end{array}$ \\
\hline
\end{tabular}


presented are physical aspects 'of the community. Altering these aspects of the community will affect long term changes in energy growth because it is the structural and developmental components of the community which most affect the manner in which growth in energy consumption takes place. The information presented in this matrix can be used as a guide to the planner or the matrix format can be used as a tool to apply to specific communities.

The functions which are identified are those functions over which the community/local government has traditionally had a role in shaping either through its explicit responsibilities and controls or due to less explicit influence:such as the overall community values and attitudes. Shaping these values and attitudes is perhaps as important in guiding the direction of the community as planning itself, especially with regard to energy. ${ }^{6}$ The controls and the responsibilities of the local government are exerted or tended to through many mechanisms such as building codes and maintenance agencies, such as the public works department. Values and attitudes of the community are expressed in many ways including the community master plan. A more detailed discussion of implementation mechanisms and resources available to the community will take place in Chapter V.

The community functions in table II- 1 are considered under two headings. These are "present looking functions" and "future looking functions". Future looking functions encompass those physical aspects of the community that will ultimately exist and must be planned for but, in fact, do not exist at 
at present. Present looking functions are those aspects of the community which are existing, thus the role of the community/local government is to maintain these aspects of the community. Future looking community functions are greatly subject to community influences because they lend themselves to full conceptualization, whereas present looking functions lend themselves to limited conceptualization. This idea is important, particularly to the planner who is most often involved in future looking functions. The temporal nature of the community function is a large factor in determining the approach to implementation and the extent of results in any type of community program, including energy conservation.

These eleven functions encompas the end use sectors within which the greatest energy savings in the community are possible and which most lend themselves to implementation through resources and mechanisms which have traditionally been applied by the planner and the community to obtain community goals and objectives. Community energy conservaiton goals and objectives should be integrated within the overall goals and objectives of the community in order to be given proper and thorough consideration. Some means for integrating community energy management goals and objectives with other compatable goals and objectives of the community are addressed subsequent$1 y$.

\section{INTEGRATING ENERGY INTO THE MASTER PLAN}

Prior to presenting approaches to integrating energy into the comprehensive plan it is necessary to establish a clear definition of the terms goal, policy and objective. These are 
terms which are loosely used in the planning profession. A lack of clear definition of these terms can make the task of plan development much more complex than it has to be. Although definitions of these terms do vary slightly from planner to planner and from plan to plan, the most workable definitions come from Morris Hill. Hill's definitions are as follows:

1. Goal - and end to which a planned course of action is directed.

2. Objective - denotes an attainable goal that has instrumental value in that it is believed to lead to another valued goal rather than having intrinsic value in itslef. Objectives are defined operationally so that either the existence or nonexistence of a desired state or the degree of achievment of this state can be established.

3. Policy - the specification in concrete details of ways and means for the attainment of planned objectives. 7

Other terms which are frequently used by the planner in master planning and which could benefit by definition are as follows:

1. Ideal - a horizon allowing for infinite progression in its direction.8

2. Values - the system of preferences which governs action in society. 9

To the planner, the relationship of the concepts depicted by these terms is fundamental. The concepts of ideal, goal, value, objective, and policy relate to one another on a continuum. This relationship has been dubbed by one planner as a system of interlocking circles and spirals depicting "planning in action". 10 The task of identifying and establishing the specific make up of these concepts, along with the implementation strategies appropriate to them, is the essence of planning. Figure II-3 is one way of depicting the relationship 


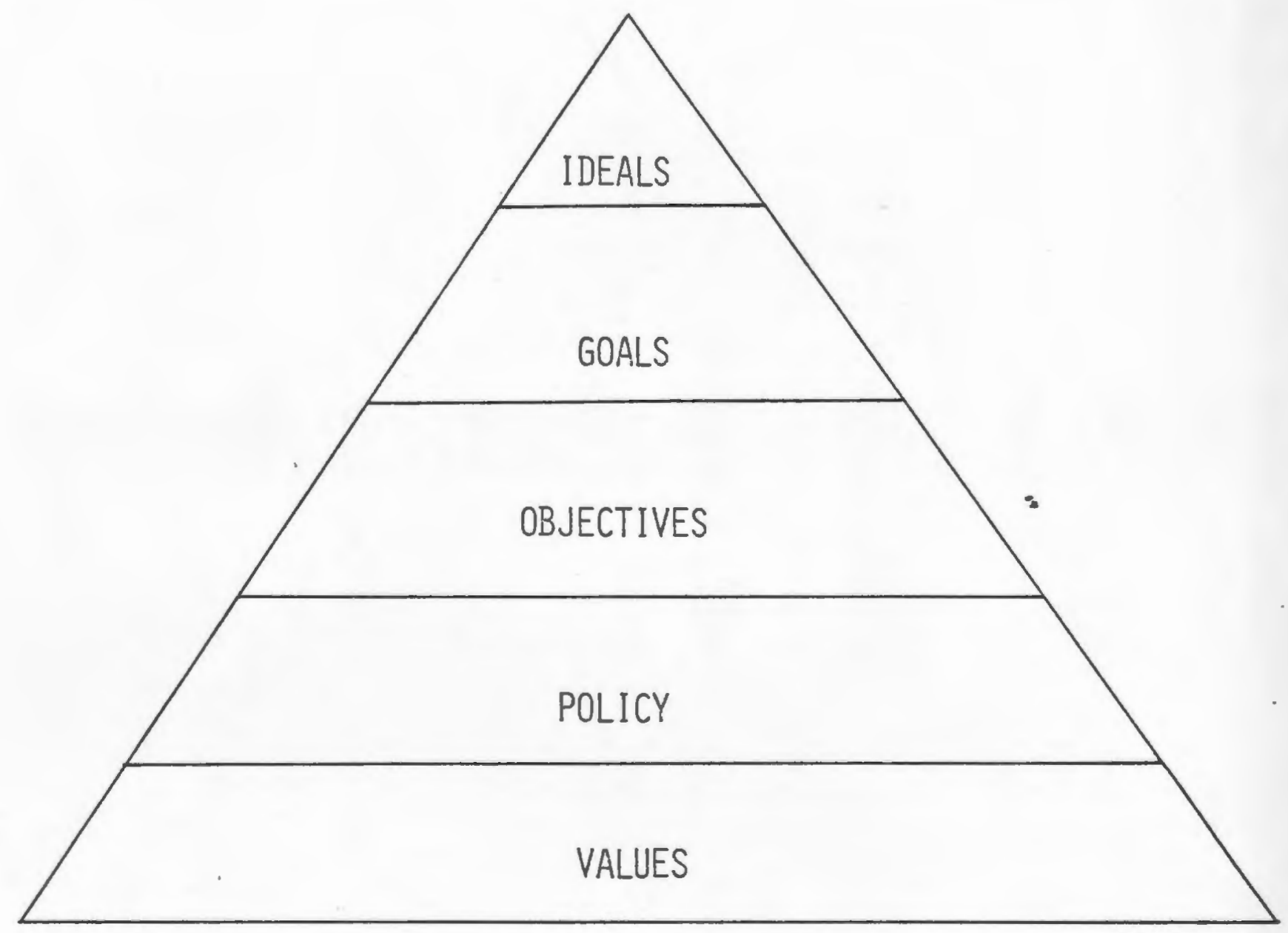

Figure II-3 One way of depicting the relationship between values,policy, objectives, goals, and ideals. Ideals are depicted as the pinnacle of the triangle, while its base is made up of the values of the community. Any change in the base will change the shape of the entire triangle. 
of these concepts. The examination of an actual community master plan will help to specify the possible linkages between energy concerns and other concerns and components of the master plan. The document to be examined, forthwith, is a comprehensive plan for a suburban community which is fairly typical of New England. It is developed and presented in the traditional mode, with a focus on three major elements: land use, community facilities, and highways. The community has a population of 15,000 and is 15 square miles in size.

This community has established the following goals in its comprehensive community plan:

1. To encourage population growth providing such growth takes place in an orderly and efficient manner.

2. To provide a range of possible housing densities based on the availability of public utilities, physical conditions, community facilities and existing patterns of development.

3. To broaden the employment base by promoting gowth of established firms and location of new industries.

4. To promote and insure the use of physically sound and safe structures for human habitation.

5. To accomodate the expansion of business activities by providing viable primary shopping complexes and highway and service areas.

6. To provide an efficient and economical program of community facilities and services commensurate with population gowth, in accordance with accepted standards and in locations designed to best serve the needs of the community.

7. To provide an efficient uninterrupted flow of both through and local traffic throughout the Town.

8. To coordinate the development of the town with those of adjacent communities.

9. To enable the Town to qualify for State and Federal financial and technical assistance for planning, 
public works, and other development programs.

10. To provide recreation areas for all age groups in each district of the Town, and to preserve and improve water courses and adjacent natural areas. 12

Table II- 2 presents a framework for analysis of the implications of the goals which have been established by the case community in its comprehensive plan. This analytical tool can be used to establish linkages between the goals of the master plan and its implications for other characteristics and resources of the community. Figure II-2 provides an assessment of the case community's goals based on their face value, that is, out of the context of the comprehensive plan. This first cut analysis enables the identification of only the obvious linkages which are explicitly expressed in the goal statement. Use of this matrix allows for the identification of the main thrust of individual goals and the cumulative impacts of the goals. Placing these goals within the context of statements of objectives and policies will enable more detailed and meanin analysis of each goal and more specific identification of the impacts. Without knowing these objectives and policies the goals remain somewhat nebulous and any further attempt to make judgements about their impacts would be erroneous.

This tool should be used during plan development to identify those characteristics of the community which are affected by master plan goals, determine the level of their energy implications, and generate alternatives for achieving the desired goals in an energy efficient manner and through the attainment of energy objectives. For example, table II-2 points to increasing accessibility as a desirable objective for the achiev- 
Table II-2 IMPNCTS OF CASE COMMUNITY'S GONLS

\begin{tabular}{|c|c|c|c|c|c|c|}
\hline & ECONOMIC & $\begin{array}{l}\text { PUYSTCD } \\
\text { GROTTR } \\
\text { AND MORE } \\
\text { STRUCTUES }\end{array}$ & $\begin{array}{l}\text { ACCESS } \\
\text { IND POX- } \\
\text { IMITYOF } \\
\text { LAND USE } \\
\end{array}$ & $\begin{array}{l}\text { INTEN- } \\
\text { SITY OF } \\
\text { LAND USE }\end{array}$ & $\begin{array}{l}\text { DIRECT EN- } \\
\text { ERGY USE E }\end{array}$ & $\begin{array}{r}\text { INDIRECT } \\
\text { ENERGY USE } \\
\end{array}$ \\
\hline $\begin{array}{l}\text { 1. Encourage orderly and efficient } \\
\text { population growth. }\end{array}$ & related & strong & strong & $\begin{array}{c}\text { indetermin- } \\
\text { ate }\end{array}$ & strong & strong \\
\hline $\begin{array}{l}\text { 2. Provide a range of housing densities } \\
\text { considering utilitics, community fa- } \\
\text { cilitics and current land uses. }\end{array}$ & $\begin{array}{c}\text { indetermin- } \\
\text { ate }\end{array}$ & strong & strong & strong & potentially & potentially \\
\hline $\begin{array}{l}\text { 3. Broaden employment base by promoting } \\
\text { growth of present industry and loca- } \\
\text { tion of new industries. }\end{array}$ & strong & strong & $\begin{array}{c}\text { indetermin- } \\
\text { ate }\end{array}$ & $\begin{array}{c}\text { indetermin- } \\
\text { ate }\end{array}$ & related & related \\
\hline $\begin{array}{l}\text { 4. Promote and ensure the use of phys- } \\
\text {. ically sound and safe housing. }\end{array}$ & $\begin{array}{c}\text { indetermin- } \\
\text { ate }\end{array}$ & strong & $\begin{array}{c}\text { Indetermin- } \\
\text { ate }\end{array}$ & $\begin{array}{c}\text { indetermin- } \\
\text { ate }\end{array}$ & strong & strong \\
\hline $\begin{array}{l}\text { 5. Accomodate the cxpansion of business } \\
\text { activities by providing viable shop- } \\
\text { ping arcas and lighway service areas. }\end{array}$ & strong & strong & strong & related & $\begin{array}{l}\text { strong } \\
\text { (transp.) }\end{array}$ & related \\
\hline $\begin{array}{l}\text { 6. Provide efficient community facili- } \\
\text { tics and services in good locations } \\
\text { and which serve community needs. }\end{array}$ & weak & related & strong & related & $\begin{array}{l}\text { strong } \\
\text { (transp.) }\end{array}$ & related \\
\hline $\begin{array}{l}\text { 7. Provide and cfficient flow of thro- } \\
\text { ugh and local traffic. }\end{array}$ & weak & related & strong & related & $\begin{array}{l}\text { strong } \\
\text { (transp.) }\end{array}$ & related \\
\hline $\begin{array}{l}\text { 8. Coordinate development with adja- } \\
\text { cont communities. }\end{array}$ & related & related & related & $\begin{array}{c}\text { indetermin- } \\
\text { ate }\end{array} \mid$ & related & related \\
\hline $\begin{array}{l}\text { 9. Enable the town to apply for TA } \\
\text { runds for planning, public works, } \\
\text { and development programs. }\end{array}$ & strong & strong & & & & \\
\hline $\begin{array}{l}\text { 10. Provide recreation areas in a } 11 \\
\text { parts of the community and preserve } \\
\text { natural resources. }\end{array}$ & weak & strong & strong & $\begin{array}{c}\text { Indetermin- } \\
\text { ate }\end{array}$ & strong & related \\
\hline
\end{tabular}


ment of three of the ten goals listed. The strong correlation between energy consumption and accessibility is apparent from the matrix. Establishing a goal of reducing energy consumption in the transportation sector through promotion of mass transit and accomodation of alternative transportation modes would be very compatable with these goals. This goal would result in the same implications for accessibility as the other three goals, but for different purposes. In fact, this community could very well have improved the organization of its master plan by making accessibility the goal for the purposes of servicing commercial districts, accomodating through and local traffic, and achieving energy reductions in the transportation sector. Objectives could then more easily be established to achieve the goal which is common to these purposes. Other examples can be culled from this matrix.

The terms "direct energy use" and "indirect energy use" are explained in the next chapter. A knowledge of the facts of energy consumption, both generic facts and community specific facts, is very important in energy planning and in the effective application of the analytical tool provided by table II-2. Chapters III and IV will address these facts as well as tools for collecting community specific data. 
'Alan Black, "The Comprehensive Plan". In Principles and Practices of Urban Planning, ch. 15; p. 349. Edited by William I. Goodman and Eric C. Freund. (Hashington, D.C.: International City Managers Association, 1968).

2 Ibid. pp. $349-371$.

${ }^{3}$ Me1 Scott, American City Planning, (Berekley: University of California's Press, 1971) pp. 242-248.

${ }^{4}$ Federal Water Pollution Control Act Amendments of 1972 , Title II, Grants for Construction of Treatment Works, sec. 208, Areawide Waste Treatment Management.

${ }^{5}$ Ron Davis, "208 Report", Practicing Planner, vol.6, no. 4 (Sept. 1976): 38-40.

${ }^{6}$ For a discussion of the planner's role in educating the public about energy and shaping the public's values and attiudes see, Comer L. Taylor Jr., "Planning and Energy Conservation", Practicing Planner, vol. 8, no. 2, (June 1978), pp. 6-7.

7 Morris Hill, "Goals-Achievement Matrix", Journal of the American Institute of Planners, vol. 35, no. 1 (January 1968): $19-28$.

8 Ibid.

9"Comprehensive Community Energy Planning", draft prepared for the U.S. Dept. of Energy, Division of Building and Community Systems by Hittman Associates, 1978.

${ }^{10}$ Alfred J. Kahn, Theory and Practice of Social Planning, (New York: Russe11 Sage Foundation, 1969), 60-95: William Ferguson, "Model for the Interface of Social and Environmental Planning", (typewritten paper prepared for graduate school planning course), November, 1975.

${ }^{11}$ North Providence, Rhode Island, Comprehensive Community Plan, prepared by the Dept. of Community Affairs, Planning Division, 1968. 


\section{CHAPTER ' I I I}

\section{ENERGY USE IN BUILDING AND BUILDINGS}

\section{Introduction}

The planner's ability to serve a useful function relative to community based energy planning is largely dependent upon two things. They are:

1. his ability to assemble meaningful and valid information,

2. his ability to apply this information to plan development and implementation.

Chapter III focuses on energy consumed in three areas. These areas are the manufacture of products, in construction, and in the operation of buildings. This chapter addresses structures as individual entities taken out of the context of the community as a whole. Because it addresses structures it will encompass the industrial, commercial, residential, and government buildings end use sectors. The information presented has meaning for both new and existing buildings as well as for physical maintenance of the community. Chapter IV takes more of a holistic approach by looking at energy in the context of the overall physical makeup of the community.

In recent years, much headway has been made in the monumental task of understanding how energy is used in the three aforementioned areas of Chapter III. However, most of this information lays idle in reports and is yet to be applied for practical purposes and in the solving of actual problems. This will be part of the job of Chapter III. Chapter III will present this data, demonstrate how it can be applied by the planner, and identify and discuss methodologies which were used in 
its collection. Much of the data presented in Chapter II is generic data. Sources of, and methods for, gathering and utilizing community specific data will be presented as well. However, because community energy data collection is such an enormous task the application of generic data to specific community circumstances may be the most feasible approach to energy planning research.

When assembling data the planner must understand the distinction between primary or original data and secondary data. Primary data is the data which the planner or researcher collects for himself. Secondary data is data which has already been compiled by other agencies or individuals. When deciding whether to undertake primary data collection or to rely on secondary data the planner/researcher must be cognizant of several considerations.

The collection of primary data is costly and time consuming. An accurate assessment of costs and time requirements for undertaking primary data collection must be made prior to undertaking the task. A decision must be made as to whether the planning process can accomodate these factors without disrupting its timeliness or creating a project cost imbalance. On the other hand collection of primary data may be required due to a complete data gap or due to serious questions of validity about existing data. Primary data collection can sometimes provide an educational function that may be useful to the community and the planner by exposing people to issues and aspects of their community that they have never had to think about. Providing for timely public release of the results of the data 
collection process can further focus public attention on the subject matter and issues of the study.

Secondary data has the advantage of being readily available and inexpensive to collect. However secondary data may be inaccurate because it is outdated or not accurately transferable from one situation to another. Also, the accuracy and bias of its collector mus be a consideration. When utilizing secondary data some of the educational advantages, attributed to primary data collection, are lost.

Some combination of primary data and secondary data is usually the best approach in conducting planning research. Whatever the planner decides, he should always be careful to fully consider the implications and documenting his reasons for selecting a particular approach. During the data collection process the planner should also document methodologies, data sources, and assumptions which were made during the process of data collection and analysis. ${ }^{1}$

\section{DEFINING TERMINOLOGY}

Energy consumed can be defined under two categories. The terminology which applies to these categories is "indirect" or "embodied" energy consumption and "direct" energy consumption. The concepts which these terms encompass are fundamental to this chapter.

The term embodied energy refers to the quantity of energy input to production of a particular good or material. Embodied energy is comprised of energy consumed in the processing, assembling, packaging, and transportation of goods and materials. Every good produced has an investment of energy embodied in it 
although, as an end product, it may or may not consume energy in their operation. This type of energy consumption is termed direct energy consumption. Other end products, such as insulation, do not consume energy but are a factor in the level of energy consumed directly. Whereas indirect energy is a measure of energy consumed per production output, direct energy is a measure of specific energy input.

As has been previously stated, this chapter focuses on energy consumed in the manufacture of products, in construction, and in the operation of buildings. Manufacture of products implies the concept of embodied energy. Under the category of embodied energy this chapter will be addressing energy consumption in industry and for the production of building materials. Under the category of direct energy consumption this chapter will address energy consumed in construction and by buildings.

\section{EMBODIED ENERGY}

Embodied energy is commonly expressed in terms of energy intensity. Energy intensity is often expressed as the number of BTU's consumed per dollar of manufacturing or the percent of value manufacturing for energy. Energy intensity can be applied to individual products or to whole industry groups to produce a meaningful statistic for use in understanding the relative level of energy use in the manufacture of goods.

Table III-l lists the energy intensity of selected end products. Table III-2 illustrates the energy intensity of New England industries by SIC. (A more complete list is included in Appendix C.)

Knowing the energy intensity, embodied energy, of products 
Table IIII-I

ENERGY INTEITSITY OF SELECTED FRODUCTS

(in thousands of Btus per \$)

\begin{tabular}{|c|c|c|c|}
\hline Eroduct & $\begin{array}{l}\text { Energy } \\
\text { Intensity }\end{array}$ & Product & $\begin{array}{l}\text { Ey } \\
\text { Esity }\end{array}$ \\
\hline liedicil, Health Services & 110 & irisc Business Services & 25 \\
\hline Tires . & 85 & Drugs & 41 \\
\hline Chemicals & 206 & Public Bldg. Furniture & 55 \\
\hline $\begin{array}{c}\text { Apparel (from purchesed } \\
\text { material) }\end{array}$ & 43 & Fertilizer & 197 \\
\hline Glass Products & 92 & Envelopes & 68 \\
\hline Refrig. Miachinery & 58 & Electric Lamps & 39 \\
\hline Sanitary Paper & 79 & Radios and TVs & 28 \\
\hline Plastics & 86 & Athletic Equipment & 52 \\
\hline Ceinned Fruit & 68 & Bakery Products & 43 \\
\hline Hend Tools & 58 & Fens and Pencils. & 48 \\
\hline Frozen Food, Vegetables & 67 & Iusicel Instmuments & 47 \\
\hline Ice Cream & 56 & Coffee & 29 \\
\hline Poultry, eggs & 68 & Wiood Househod Furni. & 40 \\
\hline lietsl Cutting Toosl & 35 & Electronic Components & 44 \\
\hline Soft Drinks & 54 & liattresses & 52 \\
\hline Pickles & 65 & Sugar & 107 \\
\hline Silverw:re & 40 & Hardware & 65 \\
\hline Footware (except mubber) & 35 & Phono Records & 49 \\
\hline Fottery Products & 80 & Witches, Clocks & 38 \\
\hline
\end{tabular}

Source: R.A. Herendeen and C.Fif. Bullard, "Energy Costs of Goods and'Services", (University of Illinois), November 1974 .

BTU CONTENT OF SELECTED FUELS

$\begin{array}{ll}\text { Distillate l gallon }=125,800 \\ \text { Residul } & \text { I gallon }=125,880 \\ \text { iatural Gas } 1 \text { cubic ft }= & 1,025 \\ \text { Electricity l krh }=3,412\end{array}$


TrbIe III-2

TOTAI PURCH: SE EIEYSY COSRS AS A

PERCEHT CF VI.ZEE ADDED

\begin{tabular}{|c|c|c|c|c|c|c|c|c|}
\hline sic & sector & ㅁ. .s. & $\underline{C I}$ & $\underline{I E}$ & 证 & IE & $\underline{\mathrm{RI}}$ & $\underline{V I}$ \\
\hline 20 & Food and rindred Frdts & 4.3 & 3.6 & 11.2 & 3.4 & 4.7 & 3.9 & 4.1 \\
\hline 205 & Bakery Products & 1.9 & 3.0 & - & 2.8 & -- & - & - \\
\hline 22 & Textile Rill Prdts & 5.2 & 8.0 & 7.0 & 6.8 & 5.7 & 8.1 & - \\
\hline 225 & Enitting itills & 3.7 & - & - & 3.2 & 2.8 & 8.2 & -- \\
\hline 23 & Apparel & 1.1 & 1.7 & 1.0 & 1.2 & 0.9 & 1.5 & -- \\
\hline 24 & Iumber and Tood Prdts & 4.2 & 6.0 & 6.3 & 4.1 & 4.0 & - & 6.4 \\
\hline 25 & Furniture and Fixtures & 1.8 & 1.9 & 2.8 & 2.7 & 2.9 & - & 5.2 \\
\hline 26 & Paper and Allied Prats & 10.0 & 13.3 & 21.8 & 12.7 & 17.5 & 10.3 & 10.4 \\
\hline 27 & Printing and Publishing & 1.0 & 1.2 & 1.3 & 1.3 & 2.2 & 1.1 & 1.2 \\
\hline 28 & Chemicals & 7.7 & 6.1 & -- & 5.7 & 7.7 & 5.3 & - \\
\hline 30. & Rubber and Plastics & 3.6 & 6.1 & 5.8 & 6.3 & 4.0 & 3.6 & 5.8 \\
\hline 31 & Leather Goods & 2.5 & - & 2.8 & 2.5 & 3.6 & - & - \\
\hline 314 & Footware (ex rubber) & 1.1 & - & 1.4 & 1.1 & 1.2 & - & - \\
\hline 32 & Stone, Cley, Glass & 10.7 & 6.4 & 17.9 & 5.8 & 9.1 & 17.2 & 4.8 \\
\hline 33 & Primery liet $1 \mathrm{~s}$ & 11.2 & 8.8 & - & 5.3 & - & 6.4 & - \\
\hline 34 & Fabricited Letsis & 2.3 & 3.0 & 5.5 & 3.5 & 2.3 & 3.6 . & - \\
\hline 35 & Won Electricel kiuch. & 1.5 & 2.5 & 2.9 & 1.5 & 1.6 & 2.2 & .2 .3 \\
\hline 36 & Electrlcel Equipment & 1.6 & 1.8 & $1: 3$ & 2.1 & 1.4 & 2.0 & - \\
\hline 37 & Transportation Equipment & 1.8 & 2.1 & - & 3.5 & 3.8 & 1.8 & - \\
\hline 38 & Scientific Instruments & 1.2 & 1.8 & - & 1.5 & 1.4 & 2.6 & - \\
\hline 391 & Jewelry. & 1.4 & - & - & 1.1 & - & - & - \\
\hline
\end{tabular}

source: Susan K Raskin, "The Hanuficturing Industrles' Energy Requirements in New England and the United Stateg" Technicr. I Report No. hitT-IVEMIS-77-008TR, (Boston:

Bew Englana Regionel Comission, 1577), Táble 1. 
and industries is important in two ways. First, it provides a presentation of data on energy consumed for the manufacture of construction materials used in the community. Second, it provides generic data on the energy consumed by the industries in the community.

Data on embodied energy of construction material gives the planner information he needs to assess the marginal costs and benefits of alternative construction projects in the community. It also gives the builder additional information when choosing amongst alternative materials and designs for construction projects. Information on embodied energy becomes increasingly important as the cost of energy rises. Fature construction or capital improvements that are being considered in the community by building committees or in master plans would best serve the community through their cognizance of embodied energy in construction.

Data on embodied energy is also important when evaluating community based industries from an energy stand point. In lieu of energy information for specific plants in the community, embodied energy data for industry groups and products provides a good indication of the relative importance of energy to various firms in the community and to the industrial sector of the community as a whole. This generic information can be derived by state for industries from the U.S. Bureau of Census and Bureau of Mines. ${ }^{2}$ This information can be used to target programs or further study. Industries which are energy intensive have a higher investment in energy and therefore can be expected to be more concerned about managing energy use in an 
effort to maintain their profitability and their stability in the community.

Information compiled by the Rhode Island Governor's Energy office verifies the significance of energy intensity data as an indicator of the importance of energy management to industry groups. ${ }^{3}$ In a survey of the nine most energy intensive industries in the state eighty percent of the firms responding indicated that coping with the cost of energy was important to the success of their business.

\section{EMBODIED ENERGY AND INDUSTRY}

Although embodied energy data is being touted as the fundamental information for analyzing industry and planning conservation programs for industry, the groundwork of establishing a detailed inventory of manufacturing firms in the community must be undertaken as the first step. There are several sources that the planner can turn to for this information. They are local or regional industrial development agencies, Chambers of Commerce, the local taxation office, and the state taxation department. In the state of Rhode Island the Department of Economic Development has established and maintained a directory of manufacturers. ${ }^{4}$ This directory 1 ists all manufacturing firms in the state by town and by SIC. Similar directories may be available in other states and regions.

Once the inventory is completed, the firms should be 1isted by two digit SIC. Energy intensity data, expressed in percent value added ${ }^{5}$ can be obtained from, U.S. Bureau of Census, Annual Survey of Manufacturers. This information is available by area by SIC. This energy data should then be 
matched with the inventory by SIC to establish the relative energy intensity of each industry group. Table III-2 lists total U.S. and New England energy intensity data by industry group. ${ }^{6}$ This U.S. data can be used to compare with area specific data to obtain a better perspective of the significance of the $10 \mathrm{cal}$ data.

At this point the planner has to make a decision as to one of three options. They are: (1) begin program development based on the data obtained, (2) undertake primary data collection, (3) present embodied energy data to the chief executive governing body and recommend a direction and resources necessary to persue that direction. In most cases the planner"will want to undertake option (3) at this stage in order to gain support and build a coalition for options (1) or (2). The decision as to whether to opt for (1) or (2) largely depends on how conclusive information collected during the first phase of energy research was (energy intensity information), how well targeted programs have to be in order to be effective, the financial resources available, and the support existant within the community. At this point the pros and cons of primary data collection should be carefully considered.

In many cases a decision should be made to persue the collection of primary data. A needs assessment survey of firms in the community can accomplish several things. First, it can help to accurately target informational needs. Secondly, it can help to reveal whether firms share common needs and concerns that can be addressed simultaneously in one program or help to bring firms together to solve their problems jointly. Third, 
it can provide the educational function of getting firms to think about the issues and problems that face them. Fourth, it can contribute towards developing a positive attitude on the part of the industrial community toward the local government which could conceivably serve as a factor in keeping firms in the community to remain as part of its economic base.

then undertaking a needs analysis or attitudinal survey it is important to have a good mail-out questionnaire. There are several characteristics that comprise a good questionnaire. A questionnaire should be as brief as possible, present questions clearly, put as little burden as possible on the respondent without leading him, should posess questions which have a specific purpose, should be careful to include all questions that need to be asked. Although this list is not exhaustive these are good guidelines that work in practice. Having some ideas about what types of programs potentially could be implemented prior to the development of a questionnaire is recommended where possible. In this way the need for specific programs can be tested. Use of return envelopes and postage will contribute towards a high response rate. Use of a cover letter which carefully explains the purpose of the survey, which promises disclosure of the results of the survey, which emphasizes that programs for the client group will result from it, and which stresses the importance of responding will also contribute towards a high return. Appendix C contains a needs assessment and program evaluation questionnaire which was utilized by the Rhode Island Governor's Energy Office in the development and evaluation of programs conducted in the state. Also included in Ap- 
pendix $C$ is the results of the questionnaire.

There are a number of possibilities for energy programs which could be conducted for industry. There are also many organizations which are eager to assist in the development and sponsoring of energy programs for industry. These organizations include the State Energy Office, Chambers of Commerce, Small Business Administration-Senior Core of Retired Executives, energy utilities, professional societies (engineers in particular) and others. Possible programs include technical seminars, forums for plant engineers, information dissemination, and tax incentive programs.

\section{ENERGY AND CONSTRUCTION}

The traditional job of the planner is managing physical growth and the social, environmental and economic implications of that growth. The level of construction in the community represents that growth. How significant is construction in the overall energy scheme? Overall, the construction industry consumed about 6000 trillion BTU's, or about ten percent of the total U.S. energy requirement in $1967 .^{8}$ This represents energy embodied in material and energy consumed directly at the construction site. It also represents a significant amount of energy consumption. Energy used in construction, rather than energy used by buildings, is the topic of this section. Energy consumed by buildings is the topic of the next section. Much of the information presented in this section comes from a study done by the Center for Advanced Computation, University of Illinois at Urbana. Although the study was only recently completed in 1977, the base year used for the study was 1967. As 
- a result most of the information presented in this section will be for that base year. 9

This section points out the major areas in which energy is consumed in construction. By doing so, it is hoped that decisions made in the community and by the planner will better be able to account for the energy implications. The information should serve as a guide for decision making about construction in the community. The information presented can be used to formulate specific policies and regulations about methods and materials used for private and/or public construction in the community or could be applied during review procedures when considering new construction proposals.

of all the energy used in construction less than twenty percent is consumed at the job site (direct energy). The remaining eighty percent is accounted for by embodied energy. 10 Figure III-1 illustrates that of all the energy for construction 57.4 percent is for building construction where 42.6 percent is for non-building construction. This figure also illustrates that 81.8 percent of all energy consumed for construction goes to new construction with 18.2 percent going to maintenance and repair. Figure III-2 presents this same information as a percentage of all energy consumption in the U.S. The most significant areas of energy consumption in construction are highways, new single family residential buildings, industrial buildings, and educational buildings as portrayed in Table III-3. Note also that new residential alterations and additions and highway maintenance account for significant energy consumption. Table II-4 lists the ten most energy intensive construction sectors, 


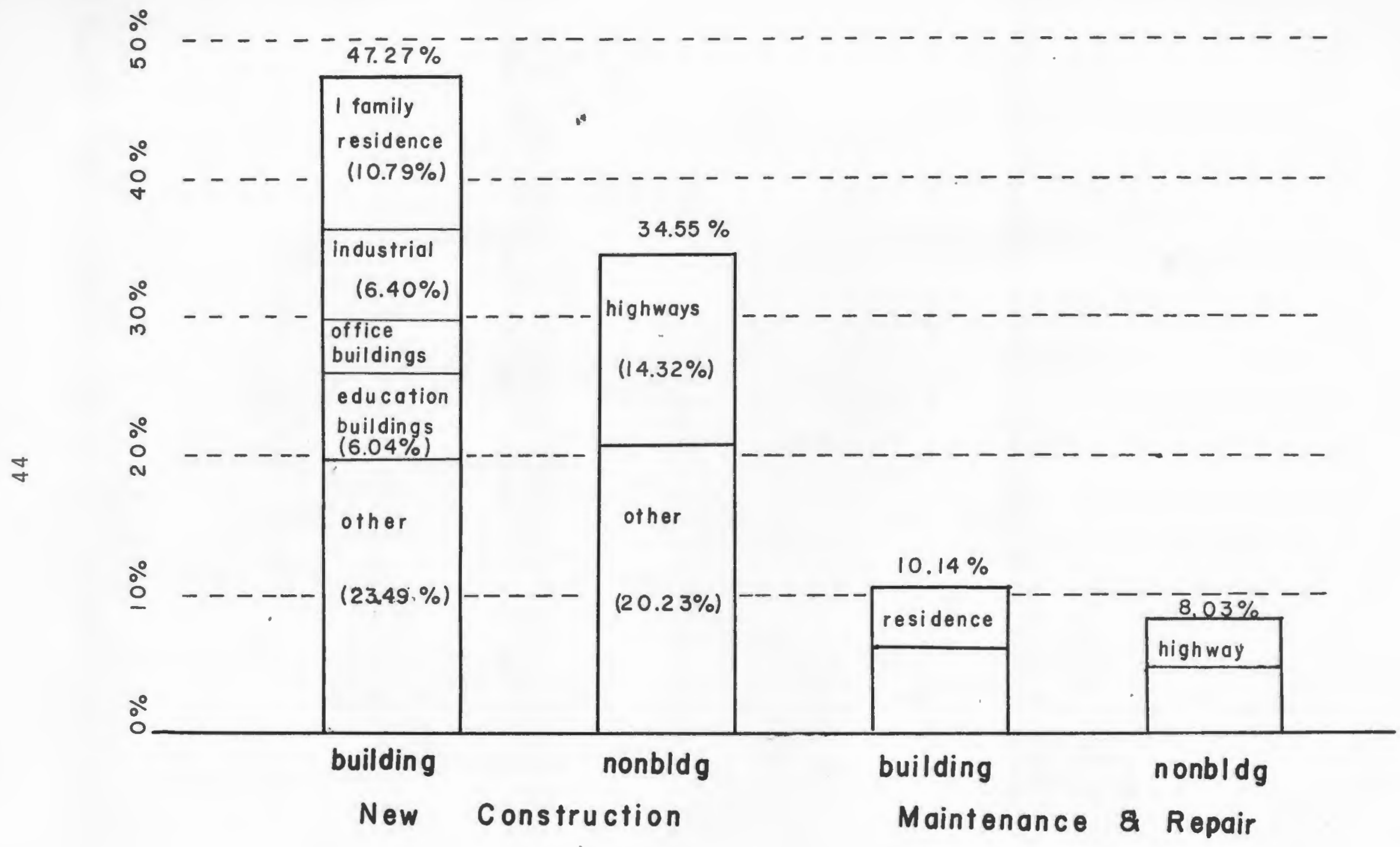

FIgure III-1 \% TOTAL CONSTRUCTION INDUSTRY ENERGY USE BY MAJOR SECTOR 


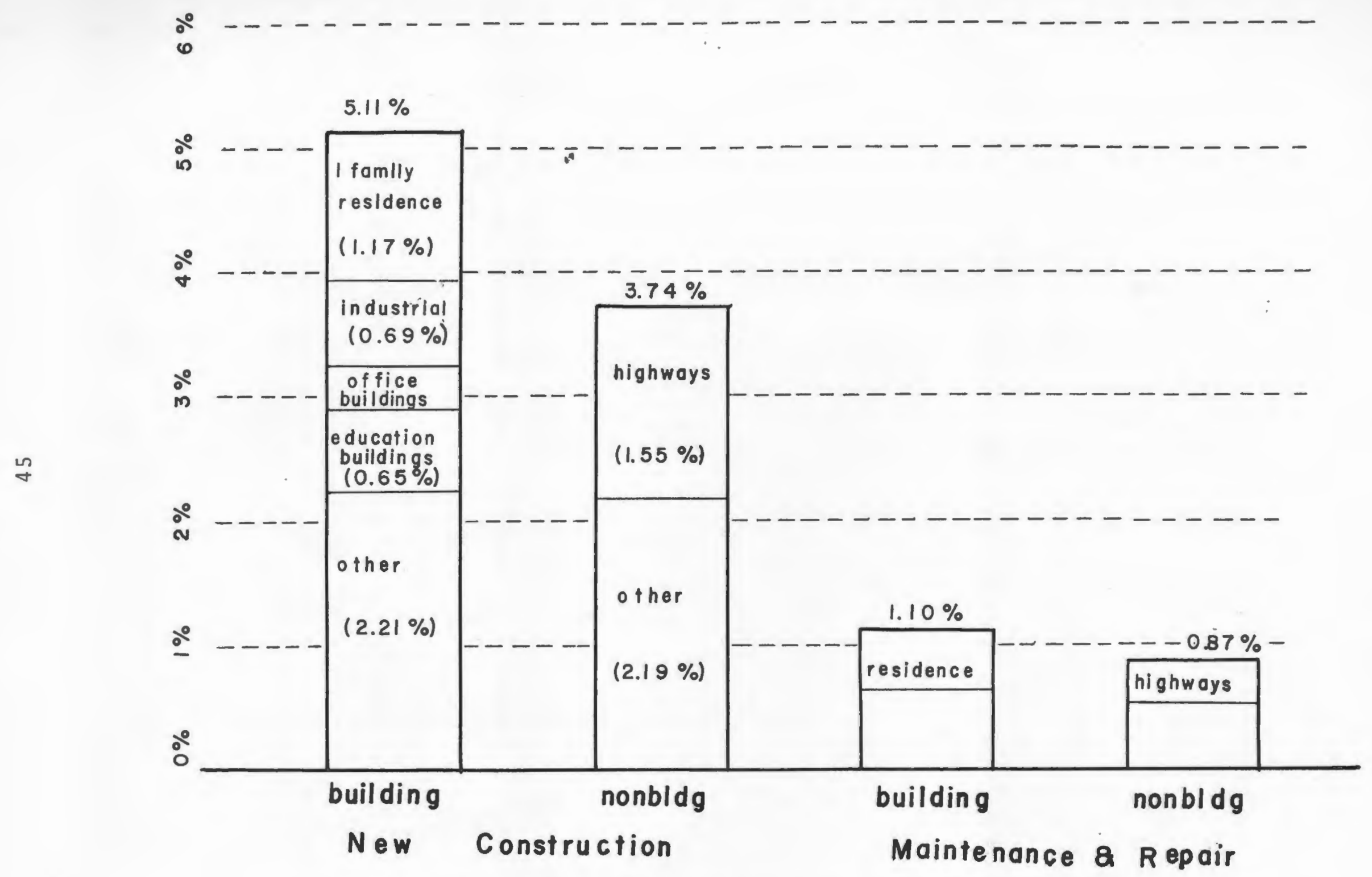

FIgure III-2 CONSTRUCTION INDUSTRY AS \% OF TOTAL U.S. ENERGY USE 
Table III-3

TEN CONSTRUCTION SECTORS REQUIPING TFE MOST

TOTAL EIERGY TO FISAI DEMAYD II: 1967.

\begin{tabular}{|c|c|c|c|}
\hline SECIOS WITH INDEX & $\begin{array}{l}\text { TOTAL EIFRGY } \\
\text { TO FRIAI DEMANT } \\
\text { (TRIILION BTU) }\end{array}$ & FERCENT & DIRFCI \\
\hline liew* Highways & 1035.87 & 39.60 & \\
\hline New Residential l-Femily & 780.98 & 9.94 & \\
\hline New Industriel Buildings & 463.38 & 8.23 & \\
\hline Iew Educetion Buildings & 437.36 & 15.48 & \\
\hline Iiew Electric Utilities & 303.94 & 12.69 & 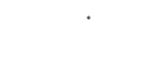 \\
\hline $\begin{array}{l}\text { New Residential Alteretions } \\
\text { \& Additions }\end{array}$ & 261.85 & 2.87 & \\
\hline Now Office Buildings & 258.66 & 17.80 & \\
\hline liew Oil \& Crs hells & 235.54 & 30.56 & \\
\hline Wew Other Non-Ferm Builciings & 231.07 & 17.50 & \\
\hline Meintenence**- Highweys & 220.00 & 43.57 & \\
\hline All Construction Sectors & $6301.04 * * *$ & 19.52 & \\
\hline
\end{tabular}

*Stends for "New Construction."

* Stands for "Meintenence \& Repair Construction."

***Pepresented $9.42 \%$ of total U.S. energy reguirement in 1967.

source:Hannon, Segal, Stein, Serber, Energy Use for Building construction, (Urbana-Chempaign, Ill.: Energy Research Group, center' for idvanced Comput:tion, University of IIIinois, Februery I977) p. II. 
TABLE 3. MEI NOST ENERGY MNTEISTYE CONSTRUCTION SECTOPS IN 1067

SECTOR

KTTE IXDEX

43. New* Petroleum Pipelines

42. New Ges Utilities

47. New Eighreys

63. Maintenance**- Petroleum Pipelines

50. Tew 011 \& Ges Vells

70. Neintenence - Oil \& Ges Wells

58. Neintenence - Ferm Service

68. Meintenence - Conservetion \& Development

51. New O11 \& Ges Exploration

54. New Other Non-Euilaing
TOTAI PRTMATY ENERGY INTERISTTY (Btu/\$)

147,197

140,038

123,745

117,158

116,895

100,103

96,288

92,963

02,941

89,466

\section{AVERAGES:}

All New Construction (32 sectors)

74,122

All Meintenence Construction ( 17 sectors)

56,182

* Stands for "Ner Construction."

* Stends for "Maintenence and Repeir Construction."

source:Hannon, Segal, Stein, Serber, Energy Use for Building Construction, (Urbana-Champaign, Ill.:Energy Research Group, Center for Advanced Computation, University of Illinois, Feb. 1977) P. 10. 
note that new highway construction ranks third. These sectors are of particular significance to the community in that they are the most familiar and predominant aspects of its physical growth. A more detailed understanding of their energy composition reveals alternatives for obtaining energy reductions. Table III-5 presents the percentage energy embodiment attributed to the various, components of construction sectors mentioned above. (note that direct energy is also included in Table III-5) This table reveals predominant energy components in each construction sector. Direct energy and stone and clay are predominant in the one family home sector while educational buildings and industrial buildings focus on a heavy énergy embodiment for fabricated metals. Energy for highway construction is heavily oriented toward direct energy consumption.

Analyzing this information in light of what we know about the energy intensity of materials from Table III-6 provides a better understanding of the energy implications of information presented in Table III-5. It also provides a basis of information from which to derive alternatives for design and construction material selection in each building sector. Table III-6 illustrates that from the perspective of embodied energy it would be desirable to avoid the use of fabricated metals in construction. Within the stone/clay products category, the use of concrete blocks is the most desirable alternative when possible. Within wood products, plywood is a reasonable alternative. Glass products present a wide range of energy intensities, with specialty glass products (for use as structural components to buildings etc.) being very intensively consumptive 


$$
\text { Table III- } 5
$$

EEP CEIT ENERGY EIBCDINEIIT FOR COHPONENTS

TO CONSTRUCTICTH SECTCRS

\begin{tabular}{|c|c|c|c|c|c|}
\hline EEterisI & $\begin{array}{l}\text { one family } \\
\text { buildings }\end{array}$ & $\begin{array}{l}\text { industry } \\
\text { builaings }\end{array}$ & $\begin{array}{l}\text { eduction } \\
\text { buildinss }\end{array}$ & $\begin{array}{c}\text { new } \\
\text { hishways }\end{array}$ & $\begin{array}{l}\text { weter } \\
\text { survar }\end{array}$ \\
\hline mood & 16.4 & 1.3 & 2.5 & 0.7 & 1.4 \\
\hline $\begin{array}{l}\text { paint } \\
\text { aspigit }\end{array}$ & 3.1 & 3.9 & 4.7 & 13.8 & 0.2 \\
\hline $\begin{array}{l}\text { stone/ } \\
\text { cley }\end{array}$ & 23.4 & 25.8 & 21.9 & 23.2 & 15.7 \\
\hline $\begin{array}{l}\text { fabricatea } \\
\text { metals }\end{array}$ & 10.6 & 29.7 & 19.0 & 7.6 & 14.4 \\
\hline $\begin{array}{l}\text { trinsprota- } \\
\text { tion }\end{array}$ & 3.4 & 2.4 & 2.1 & 2.8 & 1.6 \\
\hline$t r \approx d e$ & 7.5 & 3.4 & 4.3 & 1.9 & 2.8 \\
\hline $\begin{array}{l}\text { profession- } \\
\text { EI services }\end{array}$ & 2.2 & 1.4 & 2.4 & 0.4 & 1.0 \\
\hline àrect * & 12.2 & 12.1 & 18.9 & 47.6 & 21.4 \\
\hline otiner & 21.2 & 20.0 & 24.2 & 2.0 & $41.5 * *$ \\
\hline totel & $100 \%$ & $100 \%$ & $100 \%$ & $100 \%$ & $100 \%$ \\
\hline
\end{tabular}

source: The data used in this table was extr.cted from, Hannon, Segal, Stein, Serber, Energy Use for Building Constmuction, (Urbana-Champaign, III: Center for favanced Computation, Universtty of Ilinois). Feb. 1977, fígures AG, A7, AIO.

* Direct enerey is energy consumed on the job site. Included are coal, crude petroleum, refined petroleum, electricity, and natural gas. Products'such as gasoline diesel fuel no. 6 oil, asphalt, road oil, and propane áre considered to be refined petroleum products.

* Cf this category 31.3 percent is attributed to steel products, foundry products, and pipe. 


\begin{tabular}{|c|c|c|c|c|c|c|}
\hline \multirow[b]{2}{*}{ Ecter:ze? } & \multirow[b]{2}{*}{$\underline{u}= \pm t$} & \multicolumn{4}{|c|}{ 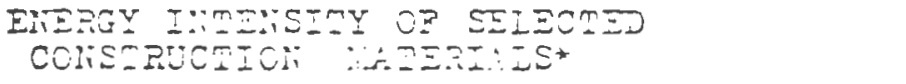 } & \multirow[b]{2}{*}{$\begin{array}{l}\text { Total at } \\
\text { Job site } \\
\text { Btu/unit }\end{array}$} \\
\hline & & $\begin{array}{l}\text { Befcre } \\
\text { Etu/s }\end{array}$ & $\begin{array}{l}\text { Delive:= } \\
\text { Etu/Li: }\end{array}$ & $\begin{array}{l}\text { Trade } \hat{\alpha} \\
\text { Btu/s }\end{array}$ & $\begin{array}{l}\text { Dezivez } \\
\underline{3 t u / u=i t}\end{array}$ & \\
\hline $\begin{array}{l}\text { standerd } \\
\text { boerd }\end{array}$ & bd $f t$ & 65,000 & 6,000 & 30,000 & 2,800 & 8,800 \\
\hline pIyंwood & sq Pt & 68,000 & 5,100 & 21,300 & 1,600 & 6,700 \\
\hline $\begin{array}{l}\text { bardwood } \\
\text { boarć }\end{array}$ & $b a ̀ ~ f t$ & 56,000 & 9,000 & 30,000 & 5,000 & 14,000 \\
\hline Eises & $8 q 1 t$ & 102,800 & $\begin{array}{l}11,800 \\
\text { to } \\
185,000\end{array}$ & 15,200 & $\begin{array}{c}1,700 \\
\frac{1}{4} \\
27,400\end{array}$ & $\begin{array}{c}13,500 \\
t 0 \\
212,400\end{array}$ \\
\hline \multirow[t]{2}{*}{$\begin{array}{l}\text { brick \& } \\
\text { structur } \\
\text { al tile }\end{array}$} & brick & 340,290 & $23, \overline{000}$ & 17,800 & $3, \overline{600}$ & $26, \overline{600}$ \\
\hline & tile & " & 32,400 & $n$ & 2,400 & 34,800 \\
\hline $\begin{array}{c}\text { odzcrete } \\
\text { block } \\
\ldots\end{array}$ & block & 141,600 & 29,000 & 13,700 & 2,800 & 31,800 \\
\hline $\begin{array}{l}\text { ready mix } \\
\text { concrete }\end{array}$ & cu $\bar{y}$ & 180,100 & $\begin{array}{l}2.6 \text { mil- } \\
\text { ilon }\end{array}$ & 655 & 9,400 & 2.6 mil- \\
\hline oement & $280^{b b l} 108$ & 479,600 & $\begin{array}{l}\text { I. } 5 \text { mil- } \\
\text { Iion }\end{array}$ & 17,500 & 55,600 & $\begin{array}{l}1.6 \text { mil- } \\
\text { Iion }\end{array}$ \\
\hline $\begin{array}{l}\text { ateel/iron } \\
\text { producto } \\
\text { bers, she } \\
\text { wire, shee } \\
\text { pipes) }\end{array}$ & $\begin{array}{l}\text { Ib } \\
\text { pes } \\
\text { ts }\end{array}$ & 267,000 & 30,400 & 13,900 & 1,600 & 32,000 \\
\hline $\begin{array}{l}\text { luminum } \\
\text { products } \\
\text { gheets, } \\
\text { bers, stap }\end{array}$ & $\begin{array}{r}16 \\
008 \\
.09\end{array}$ & 244,200 & 99,800 & 3,479 & 1,400 & 101,200 \\
\hline
\end{tabular}

Mource:Date was derived Irom, Hacan, Segl. Stein, Serber, Enerar Ilse fo- Euildin- Conctinuction; (Urbana-Cherpaiga, Ill: Center for Advanced Computation, Un. of Illinois), Feb. 1977, Pp. 4I-59. 
of energy.

Embodied energy cannot be the only factor in material selection. Material cost, performance, esthetics and other considerations must go into material selection as well. However, when these other factors are equal energy intensity of materials can provide the margin upon which a decision about building materials and designs are made. Within the buildings sector various approaches can be taken to reduce embodied energy content to building construction. Switching to less energy intense materials within a products category, substituting for traditional products with new products, decreasing the size of structures, reducing dependency on designs that mandate predominant use of certain materials, such as brick and glass in schools, can all contribute to the reduction of energy consumed in construction. Appendix C contains more complete and detailed information on the energy intensity of various building materials for reference and use in evaluating construction proposals as has been presented in this section. Included in Appendix $C$ is information on material which can be factored into decisions.

In the information for one family dwellings, which is presented in Table III-5, the large wood contribution to construction would possibly lead one to the conclusion that this sector must be the least energy intensive of all building sectors (in view of wood's comparatively low energy intensity). This is not the case however, as Table III- 7 shows that two to four family and garden apartment structures are even lower in BTU's/ ft. 2 This table also points to laboratories, hospitals, librar- 
1967 ENERGY EMBODIHENT PEA SQ FT OF BUILOING TYPE

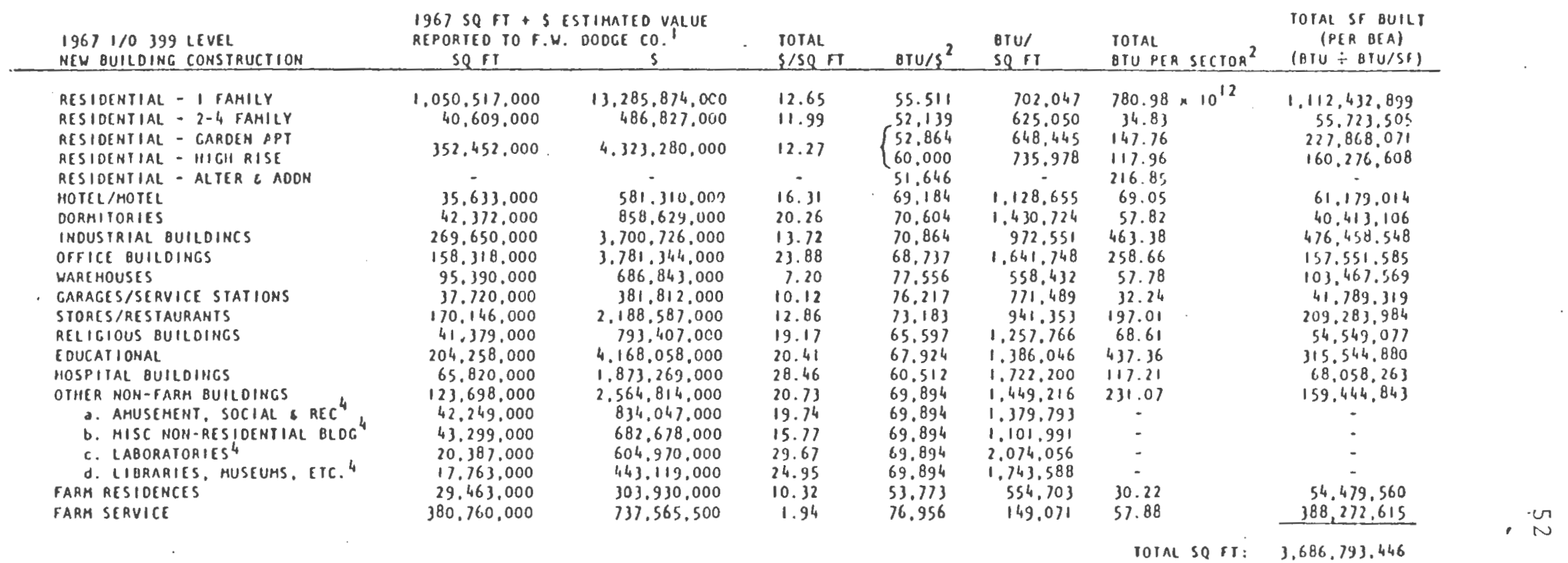

NoTES:

1. SOURCE: F.M. DODGE CO., DODCE CONSTRUCTION STATISTICS 1967 (BASED ON CONTRACTORS' BIO PRICES)

2. SOURCE: TROM CENTER FOR AOVANCED COMPUTATION

3. SOURCE: 1969 CENSUS OF ACRICULTURE. VOL. V. SPECIAL REPORTS, FARH FINANCE

4. INCLUDEO IN TOTAL FOR 38

Table III-7

source: liable tiken from, In:non, Segal, Stein, serber Energy lise

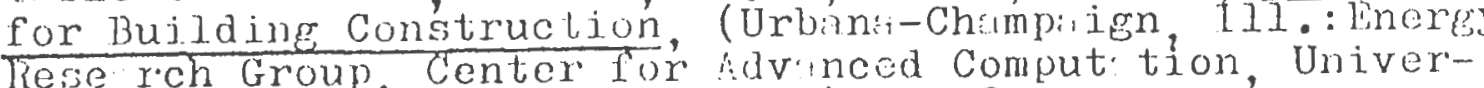

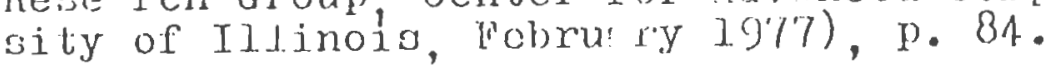


Table III-8

E:BUDIED EITPSY IOR A TYPIC:L

HULUSIIIG UIIT

( 3 bearoom seri deteched, $100 \mathrm{~m}^{2}$ )* enersy intensity

$=\operatorname{teri} I$ Biu/unit

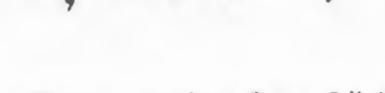

brick
steel
gless
concrete
cenent
plaster
tinber
paint

(n)

16,000
bricks
3,000
$1 b s$
300
$1 t^{2}$
20,000
$10 s$
$14 \cdot 3$
$b b l$
6,000
$1 b s$
1,400
$b d t$
12
$6 a l$

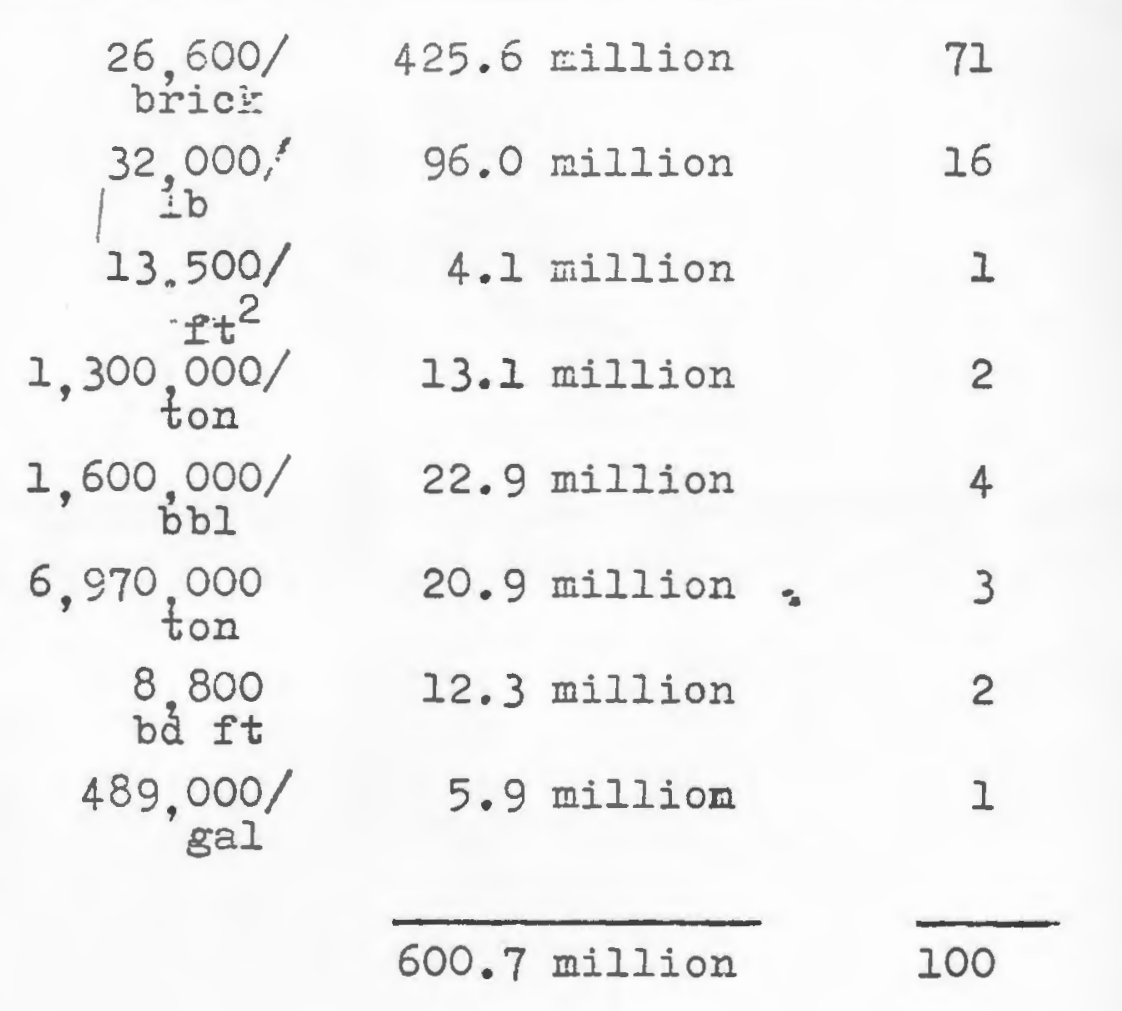

QONVERSION FECTORS

concrete:
$1 \mathrm{ft}^{3}=150 \mathrm{Ibs}$
$1 \mathrm{yd}^{3}=27 \mathrm{ft}^{3}$
$I \mathrm{yd}^{3}=4050 \mathrm{Ibs}$

board fout:

$$
\begin{aligned}
& I \times I 2 \times 12=I \text { bd ft } \\
& \frac{1 \times w \times h}{144}=b d f t
\end{aligned}
$$

* source: Data for typical house taken from, Tom Bender, "Living Iightly: Energy Conservation in Housinz", October, 1973, p. 19.

**olumn 2 (quantity) x column 3 (energy intensity) = Btu embodiment. 
ies and museums as the most energy intensive.

Application of the methodology to specific building construction projects in the community is easily accomplished. The procedure is as follows:

1. List the materials to be used in the construction project.

2. List the quantities of each material.

3. Refer to Table III-6 (or Appendix C for more detail) and determine the BTU/unit value for the materials listed.

4. Multiply the quantity of the material by BTU/unit value in Table III-6.

5. Total the figures that were determined in number four, above, and determine the percentage of energy ambodiment for each material component."

Table III-8 presents an example of how this is done for a typical one family housing unit. The predominance of brick in this particular structure is apparent. Table III-6 portrays brick as a very energy intensive building material Reduction in the amount of brick used in this structure would result in considerable energy savings. Replacing the brick with wood construction would require 1,876 board feet to cover the same surface area. The comparative BTU embodiment would be 425.6 million for the brick and 16.5 million for use of the wood substitution.

Referring again to Table III-5, opportunities for savings in the non buildings sector can be identified. Two predominant components of the community infrastructure are the water supply system and highways. Table III-5 points out that a considerable protion of the energy embodied in the water system is for steel, with pipe being one of the predominant steel products (see foot- 
note). Table III-9 illustrates the energy advantages inherent in the use of plastic pipe, with steel pipe consuming about 2.7 times the amount of energy to produce an equal amount of plastic pipe.

A viable and more energy conscious alternative exists with regard to material components to highway construction and maintenance. Table III-5, shows the high direct energy component to new highway construction. Highway maintenance construction exceeds this fugure of 47.6 percent direct energy for new highways with a direct energy requirement of over 52 percent. ${ }^{12}$ This high direct energy contribution in highway construction is due to the heavy use of asphalt which is considered a refined petroleum product. The use of bituminous emulsions as an alternative to liquid asphalts and asphalt cements can reveal energy savings because emulsions utilize less petroleum product as an ingredient and can be prepared for application with little or no heating. Since 1974 the FHWA has been encouraging the use of emulsified asphalts to save energy. The FHWA estimated that in 1972309 million gallons of petroleum product could have been saved in the U.S. through use of emulsions rather than traditional cut back asphalt products. ${ }^{13}$ Table III-10 shows why this is so.

Energy savings can be obtained in three ways with regard to asphalt applications. 14

1. Substitution of plant mixed emulsified asphalt at ambient temperature for hot plant-mixes using ashphalt cement. The primary energy saving here is elimination of the fuel required to heat and dry the aggregate. 
COPPARISON OF STEEL PIPE \& PIASTIC PIPE

(USIT: LIIEAI FOOT)

PIASTIC PIPE (PVC)

$\begin{array}{llc}\text { Diemeter } & \text { Ib/I1 } & \text { Total Btu/unit } \\ 3^{\prime \prime} & 1.53 & 71,344 \\ 4^{\prime \prime} & 2.16 & 100,821 \\ 6 " & 3.76 & 175,329 \\ 8^{\prime \prime} & 5.80 & 270,454\end{array}$

STEET PIPE

$\begin{array}{lrl}\text { Digmeter } & \text { Ib/I1 } & \text { Total Btu/unit } \\ 3^{\prime \prime} & 7.58 & 195,663 \\ 4^{\prime \prime} & 10.79 & 278,522 \\ 6^{\prime \prime} & 18.97 & 489,673 \\ 8^{\prime \prime} & 28.55 & 736,961\end{array}$

source:Hennon, Stein Segil, Diebert, Buckley, Nathan, Energy Use Ior Builaing Corstructich. Supplement, (UrbanaChitpeign, Il1.: Energy kese rch Group, Center for Advinced Computation, University of Illinais, October 1:77), p.II. 


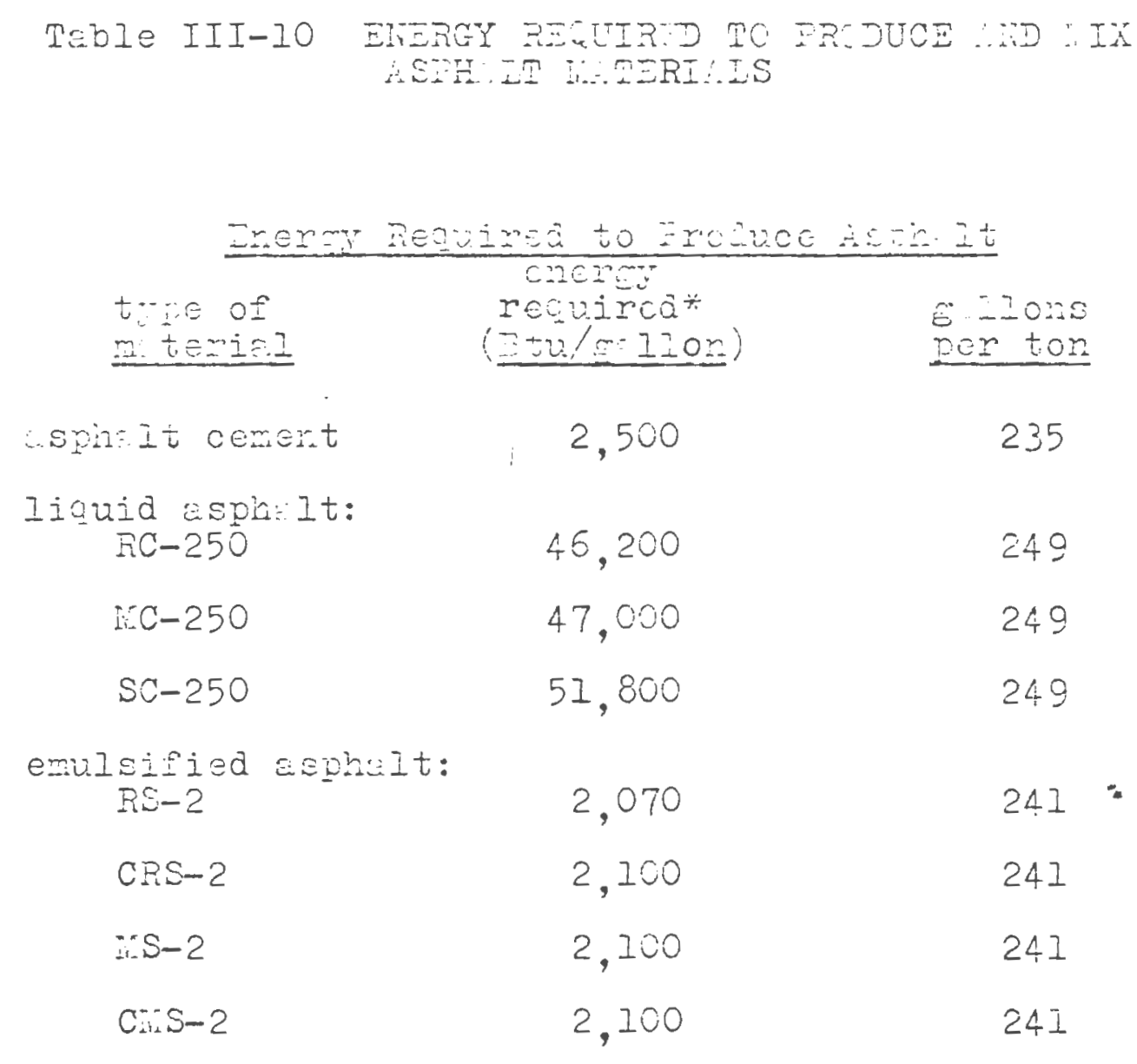

\begin{tabular}{|c|c|}
\hline $\begin{array}{c}\text { type of } \\
\text { mix } \\
\end{array}$ & $\begin{array}{l}\text { Btu/ } / \mathrm{Ja}^{2} \\
\mathrm{inch} \text { thick }\end{array}$ \\
\hline $\begin{array}{l}\text { Hot Plint-irix Asphelt } \\
\text { Concrete }\end{array}$ & 27,800 \\
\hline $\begin{array}{l}\text { Emul sified tsphalt } \\
\text { PI nt-Lix }\end{array}$ & 15,600 \\
\hline
\end{tabular}

* Does not include energy potentirl of b se espir It. *A one irch loyer of Each mix m not be structurally equivalent.

source:Transportation Resecrch Boerd, Bituminous Emulsions for Highvay Evements, (Woshington, D.C.: Trneintcitin Reserreh 5o:rd, IE75) p.5. 
2. The use of emulsified hot-plant-mixes. Energy is saved here through the reduction of temperatures for the production of mixes to 220 to $260 \mathrm{~F} .15$

3. Improved efficiency in the production of hot plant mixes could result in a savings of 22 percent according to the National Asphalt Paving Association.16

The capability of emulsified asphalts for some applications is not yet fully agreed upon within the industry however, and caution should be taken to determine this for specific applications. Table III-11 lists the various applications of emulsified asphalts which have been made in a number of states. U.S. DOT advises that engineers and technicians should receive special training in the use of emulsions to take advantage of maximum application and to ensure proper application:" Table III-12 illustrates the amount of asphalt products used in building construction sectors. Emulsions and other alternatives presented in Table III-13 may be substituted here as well.

\section{ENERGY CONSUMPTION: BY BUILDINGS}

This section addresses energy consumed by new and existing residential and commercial buildings. Table III-14 illustrates that the sectors consume a considerable amount of energy nationally. In the New England region, where the economy has matured and become oriented towards services, the contributions by these sectors is even more pronounced. Nost of the energy consumed by these sectors is for space conditioning, heating and cooling, and as a result this section will focus primarily on the thermal efficiency of construction. Space conditioning accounts for approximately 75 percent of the energy consumed in the residential sector and for about 50 percent in the commercial sector. 
TCBIE III-II STRE UEE UT EULEITAE

$\therefore$ - Stcte ues of Eulsions by ciess nd fyce

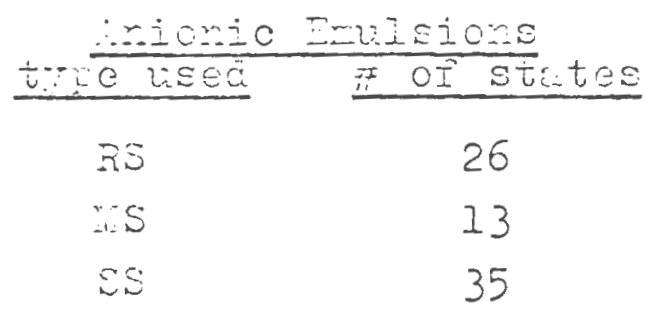

$\frac{\text { Cetionic Emusions }}{\text { tye usea }}$

CRS 35

Cis 26

CSS 20

D- St:te Use of Emulaions by Constmotion Item Irensport tion Fese rch Zo rd Survey

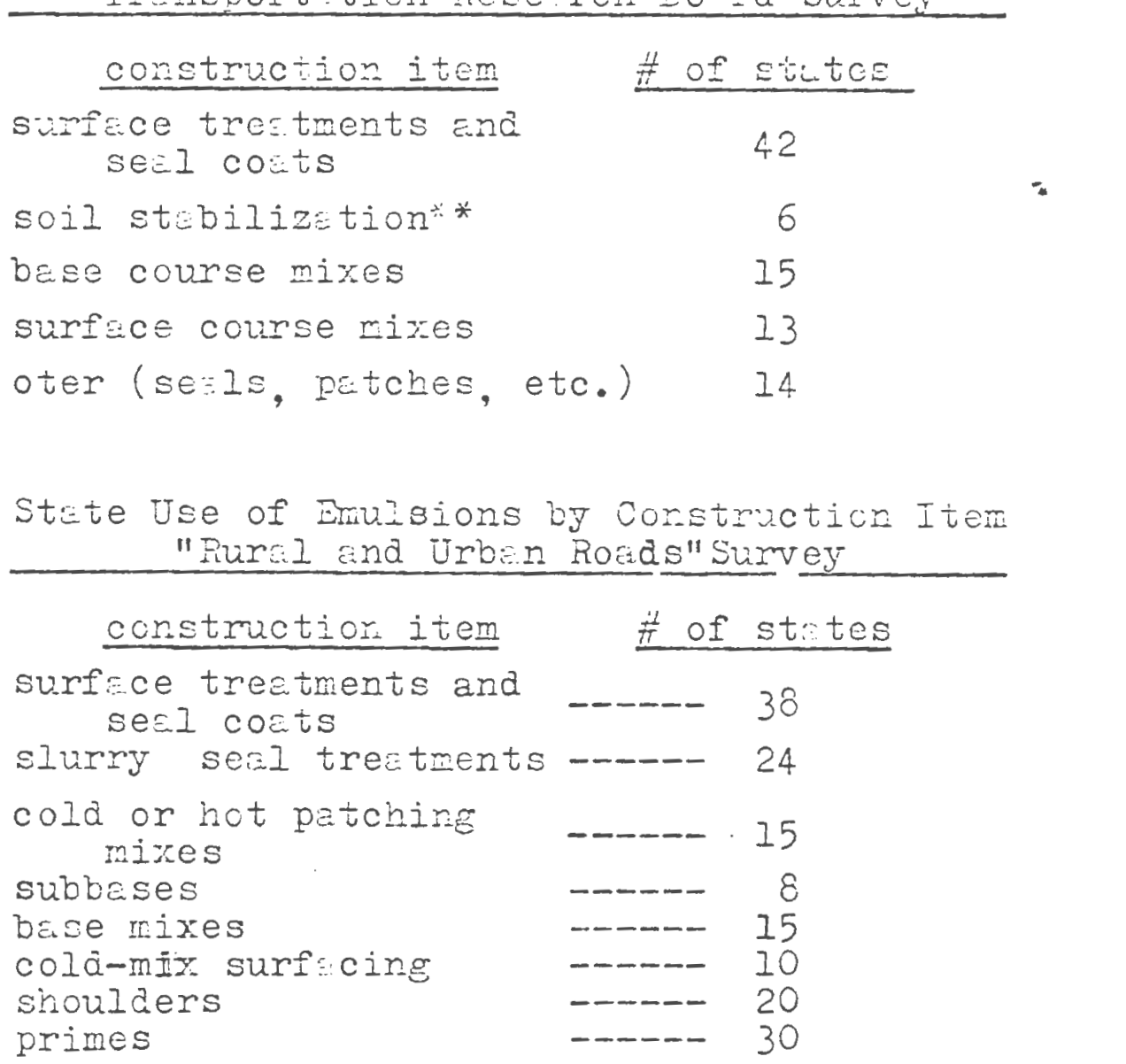

* Inform tion used in tebles $\therefore$ nd $B$ ias compilea in 1974 survey or the Trinsprot tion Reserrch bo ra cntitled "Sinvey of Enulsion Use by Stete Highway !Eencies". Inform tion in table C is found in, "How States are Using Emulsions", Rural ená Urian Roeds (seb. 1972) pp. 40-44.

* Emulsions are better for this ty Le of use then petroleum besed asphalts because they are more compatibie iith plrsts. 


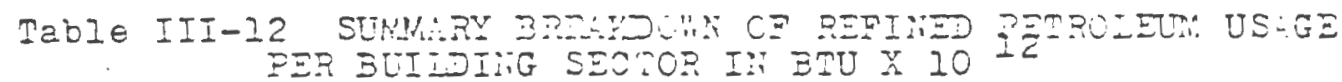

BUIDING TYPE

\begin{tabular}{|c|}
\hline 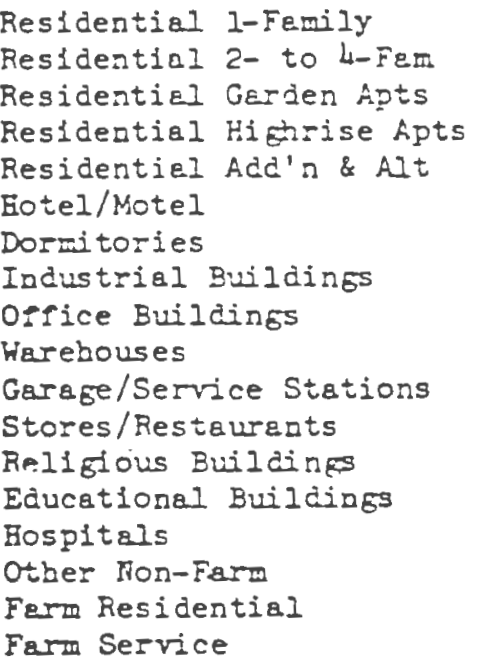 \\
\hline
\end{tabular}

Sub-Total New Builaing

Fercentages New Building

$M+R$ Residential

$M+R$ Fon-Residential

$M+R$ Farm Residential

$M+R$ Farro Service

Sub-Total $M+R$

Fercentages $M+R$

TOTAL

PERCENTAGES

\begin{tabular}{|c|c|c|c|c|c|c|}
\hline \multicolumn{4}{|l|}{ ASPHALT } & \multicolumn{3}{|l|}{ IIQ } \\
\hline$\&$ & GASOLI & ES & FUEL & PETROL & LUB & \\
\hline ROAD OII & . Gis & DIESEL & OIL & GASES & OIIS & TOTAL \\
\hline 55.38 & 31.41 & - & 1.82 & - & 0.05 & 88.66 \\
\hline 3.52 & 0.54 & 1.27 & - & - & - & 5.33 \\
\hline 17.28 & 2.01 & 5.19 & 0.53 & - & 0.02 & 25.03 \\
\hline 13.92 & $\hat{\varepsilon .29}$ & 6.12 & 0.28 & - & 0.02 & 22.63 \\
\hline 5.09 & 2.17 & - & 1.42 & - & 0.02. & 8.70 \\
\hline 8.72 & 1.46 & 3.78 & - & - & 0.02 & 13.98 \\
\hline 7.50 & 1.28 & 3.45 & 0.27 & $-i$ & 0.02 & 12.52 \\
\hline 20.44 & 3.17 & 14.47 & 5.68 & 0.93 & 0.13 & 44.82 \\
\hline 31.68 & 5.38 & 14.41 & 0.85 & 0.97 & 0.08 & 53.37 \\
\hline 4.09 & 0.50 & 2.22 & 0.75 & - & 0.02 & 7.58 \\
\hline 3.48 & 0.65 & 1.54 & 0.27 & - & - & 5.94 \\
\hline 25.04 & 4.88 & 11.58 & 1.66 & - & 0.08 & 43.24 \\
\hline $7 \cdot 31$ & 0.70 & $4: 52$ & 0.57 & - & 0.02 & 13.12 \\
\hline 46.59 & 4.10 & 26.46 & 1.13 & - & 0.08 & 78.35 \\
\hline 14.03 & 0.74 & 7.63 & - & - & - & 22.40 \\
\hline 26.93 & 4.90 & 13.04 & 1.98 & - & 0.08 & 46.93 \\
\hline 0.84 & 0.49 & - & 0.25 & - & - & 1.58 \\
\hline 1.14 & 1.17 & - & 0.83 & - & 0.02 & 3.16 \\
\hline 292.98 & 67.84 & 115.68 & 18.29 & 1.90 & 0.66 & 497.35 \\
\hline $58.9 \%$ & $13.6 \%$ & $23.3 \%$ & $3.7 \%$ & $0.4 \%$ & $0.1 \%$ & 100.00 \\
\hline 15.78 & 9.42 & - & - & 0.72 & - & 25.92 \\
\hline 15.94 & 19.08 & 1.29 & 7.26 & & 0.17 & 43.74 \\
\hline 1.37 & 0.85 & - & - & - & - & 2.22 \\
\hline 1.38 & 0.24 & - & 0.60 & - & - & 2.22 \\
\hline 34.47 & 29.59 & 1.29 & 7.86 & 0.72 & 0.17 & 74.10 \\
\hline $46.6 \%$ & $39.9 \%$ & $1.7 \%$ & $10.6 \%$ & $1.0 \%$ & $0.2 \%$ & 100.00 \\
\hline 327.45 & 97.43 & 116.97 & 26.15 & 2.62 & 0.83 & 571.45 \\
\hline $57.3 \%$ & $17.0 \%$ & $20.5 \%$ & $4.6 \%$ & $0.5 \%$ & $0.5 \%$ & 200.00 \\
\hline
\end{tabular}

Bource:Hannon, atein, ses-l, Diebert, Euckley, Nicth:n, Enonol Use for Building Construciin, Supilement, (Urb:naChampaign, I11.: Enersy Fiesc. Ich Group, Center for idvinced cozputition, University of Illinois, October 1977), p.52. Datu for bise gear 1967. 
TabIE III-13 ALTERNATIES FOR TYFIASL RE EDENTIAL DRIVEVAY (10' vide $x 45$ ' long)

Material

Asphalt (I)

Concrete (2)

Concrete strips

Brick

(3) \begin{tabular}{l} 
Energy \\
$\left(\right.$ Btu $\left.\times 10^{6}\right)$ \\
\hline
\end{tabular}

$24 \cdot 3$

20.3

(2)

6.1

69.1
Labor Cost

(man hours) (1977\$)

34

27

8

60
$\$ 420$

930

280

1,280

Notes:

(1) Asphart

Material - Mix by weight: $6 \%$ asphalt, $94 \%$ aggregate

(Civil Engineering Handbook); 1 ton of asphalt = 235

gallons (Asphalt Institute); $1 \mathrm{CF}$ of asphaltic concrete $=$

145 lbs (Asphalt Institute); 1 gallon of asphalt =

158,100 Btu (EBC Supplement, Table 5).

Therefore, 1 Ib of asphalt $=18,577$ Btu and 1 CY of

asphalt concrete $=4,363,740$ Btu.

$4 "$ thick driveway $=5.56 \mathrm{CY}$.

Labor and cost - Applied in two layers (1977 Dodge Manual)

top course, $1 \frac{1}{2} "=0.27$ man hours/SY \& $\$ 5.00 / \mathrm{SY}$

base course, $2^{1} \frac{1}{2}=0.40$ man hours $/$ SY \& $\$ 3.37 /$ SY

Total, $\quad 4^{\prime \prime}=0.67 \mathrm{man}$ hours/SY \& $\$ 8.37 / \mathrm{SY}$

(2) Concrete Material - I CY ready mix concrete $=2,594,338 \mathrm{Btu} / \mathrm{CY}$

(EBC p. 50); 1 lb welded wire mesh $=24,187$ Btu (EBC p. 55);

$6 \times 6 \times 10 / 10 \mathrm{mesh}=21 \mathrm{Ib} / \mathrm{CSF}$ (conc. Reinf. Stl. Institute

Design Handbook); 5 " thick conc. driveway $=6.94 \mathrm{CY}$ of conc.

and $94.5 \mathrm{lb}$ of mesh; 2 - 18" strips $5 "$ thick $=2.08 \mathrm{CY}$

of conc. and $28.35 \mathrm{lb}$ of mesh.

Labor and cost $-5^{\prime \prime}$ thick reinf. conc. paving $=0.54$ man hours/SY and $\$ 18.63 /$ SY (1977 Dodge Manual).

(3) Brick Material - Brick on edge $=6$ bricks $/ \mathrm{SF}$; ea brick $=$ 25,582 Btu (EBC p. 49).

Labor and cost - Brick set in sand $=1.20$ man hours $/ \mathrm{SY}$ and 25.65/SY (1977 Dodge Manual).

source:Hannon, Stcin, Diebert, Buckley, Nethan, Energy Use for Builaing Construction, Suplement, (Urbine-Ch: mpaign, IlI.: Energy Reserch Group, Center for Ajvanced Comput.tion, University of Illinois, October 1977), p.63. 


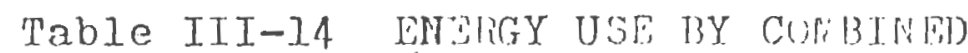

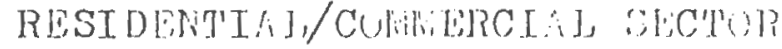

$$
\left(10^{l 2} 131: 1 x\right)
$$

\begin{tabular}{|c|c|c|c|}
\hline ye:ir & $\begin{array}{l}\text { totol moimeiry } \\
\text { energy use } \\
\end{array}$ & $\begin{array}{l}\text { total enorry urse } \\
\text { (point of use) } \\
\end{array}$ & $\begin{array}{l}\text { of by rosiscutial/conm. } \\
\text { of } 1] 1 \text { U.s. oncr.y use }\end{array}$ \\
\hline 1960 & 34,132 & $1.1,436$ & 29.9 \\
\hline 1965 & 17,759 & 13,778 & 30.4 \\
\hline 1970 & 23,227 & 16,988 & 30.4 \\
\hline 1975 & 24,848 & 17,584 & 31.2 \\
\hline
\end{tabular}

source:Table derived from, Jicpins, Smith, Rose, Hoyirood, Building Energy Uae Data Book, (Oik Ridre Tennosine: Oak Ridge Nition l. Jiboratory, april 1978) pp.18,19. 
Other significant areas of energy consumption are for lighting and water heating.

As was previously stated, the largest area of energy consumption in the residential/commercial buildings sector is space heating. This energy consumption comes as a result of the need to establish and maintain a steady state environment for man. Steady state refers to the temperature, humidity, and even light levels that occur in buildings for man's comfort and convencience. We have already discussed the energy which is consumed to create the structure within which this mini environment is contained but, the other aspect is the energy consumed in maintaining the internal environment. Climate, of course, is a big factor in the level of energy which is consumed within structures. The greater the difference between the outside conditions and the desired inside conditions the more energy will be required to create a steady state internal environment. Climatic considerations will be discussed in the next chapter.

The performance of materials was presented in the previous section as an important consideration in the selection of materials for construction. In addition to structural performance and other considerations, the thermal performance of materials should be a consideration. In many states this is already the case. As of January 197939 states have adopted statewide building codes containing thermal efficiency provisions. These codes are minimum standards and are left up to the local community to enforce. It would be advisable for communities to strive to exceed these standards by adopting more stringent code provisions or adopting review procedures 
which encourage more energy efficient construction, at least with regard to public building construction. Taking measures to weatherize existing structures by modifying buildings with materials having good thermal properties is also recommended.

Table III-15 lists the $U$ value and $R$ value of various building materials. The $U$ value represents the rate of heat transmission through a material expressed in BTU/ft ${ }^{2} /{ }^{\circ} \mathrm{F} / \mathrm{hr}$. The $R$ value is its reciprocal. U values and $R$ values are used to rate materials for their thermal efficiency. The lower the $U$ the more energy efficient the material. The higher the $R$ the more energy efficient the material.

In the previous section the embodied energy of "the construction material was the point of focus. However, no decision about the selection of a material for energy conservation purposes should be made without considering whether it is important in terms of the thermal efficiency of the structure, and if so, what the thermal performance of the material is. Any material which makes up the outside shell of a building should be assessed for its thermal performance.

Figure III-3 and Table III-16 illustrate the implications of building material selection on energy consumption in buildings. A square foot of the wood frame wall with insulation has a total $R$ value of 13.79 as compared the brick on wood frame wall with an $R$ value of 14.01 . This extra $R$ value was achieved at a cost of an extra 94,140 BTU per square foot embodied in construction. The long term comparison of these options is presented in Table III-16 where the energy consumed over a twenty year period in the brick construction is 324,206 


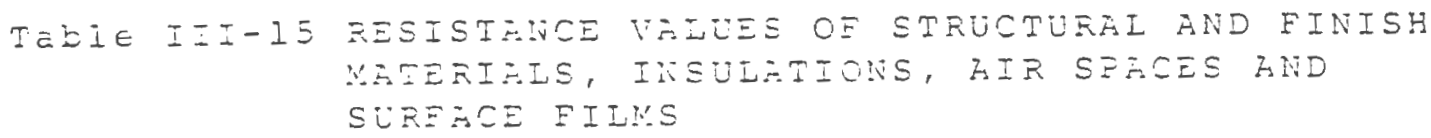

Hood beve! sidins, 1/2 $\times 8$, lazped

kood sicing stirgles, $16^{\prime \prime}, 712^{\prime \prime}$ exposure

Ascestockemen: shingles

Stucec, perinch

Building paper

1/2" riaji-bze insull. bozd shezthing

$1 / 2$ " insui, bcard sheatining, regular censity

$35,32 "$ insul. board sheathing. regular censity

$1 / 4^{\prime \prime}$ piywood

$3 / 8$ " plywood

$1 / 2$ " plywood

5/8" plywood

$1 / 4 "$ hardboard

Softwood, per inch

Softwood board, 3/4" thick

Concrete blocks, three oval cores

Cinder zesregete, 4" thick

Cinder aggregate, 12" thick

Cinder aggregate, 8 " wick

Sand and gravel agcregate, 8" thick

Lightweighi agze ezule (expanded clay, shale, slas, purrice, etc.), \&" thick

Concrete blocks, iwo rectangular cores

Sand and gravel aggregz te, 8 " thick

Lightweight aggregale, 8 " thick

Common brick, per inch

Face brick, per inch

Sand-and-gavel concrete, per inch

Sand-and-gravel concrete, $\delta$ inches thick

$1 / 2$ " Bypsumboard

5/8" gypsumboard.

$1 / 2$ " lightweight-2gğregate gypsum plaster

25/32" hardwood finish flooring

Asphzit, linoleum, vinyl, or rubber floor wile

Carpet and fibrous pad

Cappet and foam rubber pad

Asphalt roof shingies

Wood roof shingles

$3 / 8^{\prime \prime}$ built-up roof

Glass

$\begin{array}{ll}\text { Single glass (winter) } & U=1.13 \\ \text { Single glass (summer) } & U=1.05 \\ \text { insulating glass (double) } & \\ 1 / 4 " \text { air space (winter) } & U=0.65 \\ 1 / 4 " \text { air space (summer) } & U=0.61 \\ 1 / 2 " \text { air space (winter) } & U=0.58 \\ 1 / 2 " \text { air space (summer) } & U=0.56 \\ \text { Storm windows } & \\ \text { 1" to 4" air space (winter) } & U=0.56 \\ \text { 1" to 4" air space (summer) } & U=0.54\end{array}$

Insulation

$2^{\prime \prime}-2 \%^{m}$ thick

$3^{\prime \prime}-4^{\prime \prime}$ thick

$5^{\prime \prime}-7$ " thick
$R=0.81$

$R-0.87$

$R-0.03$

$R-0.20$

$R=0.05$

R.1.14

$R-1.32$

$R \cdot 2.04$

$R-0.31$

$R=0.47$

$R=0.62$

$R-0.78$

$R-0.18$

$R-1.25$

$R=0.94$

R.1.i1

R.9.89

$R-1.72$

$R \cdot 1.11$

R.200

R. 1.04

R.218

$R-0.20$

$R=0.11$

$R-0.08$

$R-0.64$

$R-0.45$

$R-0.56$

$R-0.32$

$R-0.68$

$R-0.05$

$R \cdot 2.08$

$R-1.23$

$R-0.44$

R-0.94

$R-0.33$

$=1.13$

$=0.61$

$=0.58$

$U=0.56$

$U=0.54$

$R-7.00$

R. 11.00 R-19.00

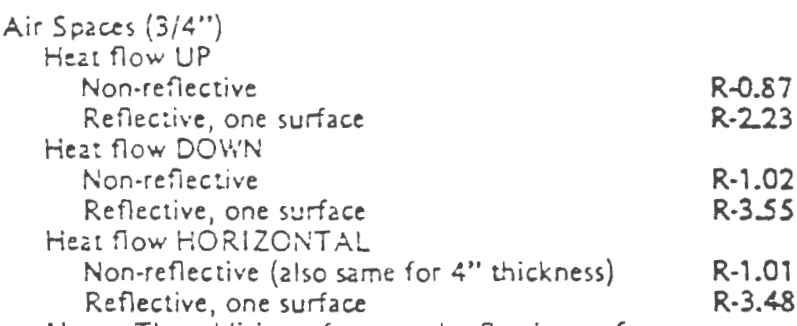

$R-0.17$

$R-0.25$

Exampie calculations

(to determine the $U$ value of an exterior wall)

$R-0.67$

$R-1.32$

$R-0.92$

24.55

Uninsulated

Wall Consruction

Wal

Hial

Outside surface (film), 15 mph wind

Resistance

Resisance

Hood bevel siding, lapped

0.17

0.17

${ }^{\prime}{ }^{\prime \prime}$ ins. bd. sheathing, reg density

0.81

0.81

3 '.

R-11 insulation

Ke" gypsumboard

Inside surface (film)

Totals $\quad \ldots \quad$\begin{tabular}{l}
0.45 \\
\hline 4.68 \\
\hline 4.44
\end{tabular}

11.00

0.45

0.68

14.43

For uninsulated wall, $U=\frac{1}{R}=\frac{1}{4.44}=U=0.22$

Therefore, heat loss for the above uninsulated wall section $2 ! 2+10^{\circ} \mathrm{F}$. outside design temperature is equal to $0.22 \times 60$ (or 70-10) equals 13.2 Biuh per sq. fl. of wail section

For insulated wall, $U=\frac{1}{R}=\frac{1}{14.43}=U=0.07$

Therefore, heat loss for the above insulated wall section $2 t$ $a+10^{\circ} \mathrm{F}$. outside design temperature is equal $100.07 \times 60$ (or 70-10) equals 4.2 Btuth per sQ. ft of wall section.

- Additional resistance values can be obtained from ASHRAE Handbook of Fundamenuls published by the Ameriean Society of Heating Refrigeraung and Air Conditioning Engineer.

Bource: Insulation liezual, (ñockgille, fid.:Nationel Assoc1stion of Hone Builders Kesearch Founcation, Sept I971) p.22. 
BRICK ON WOOD FRAME WALLS

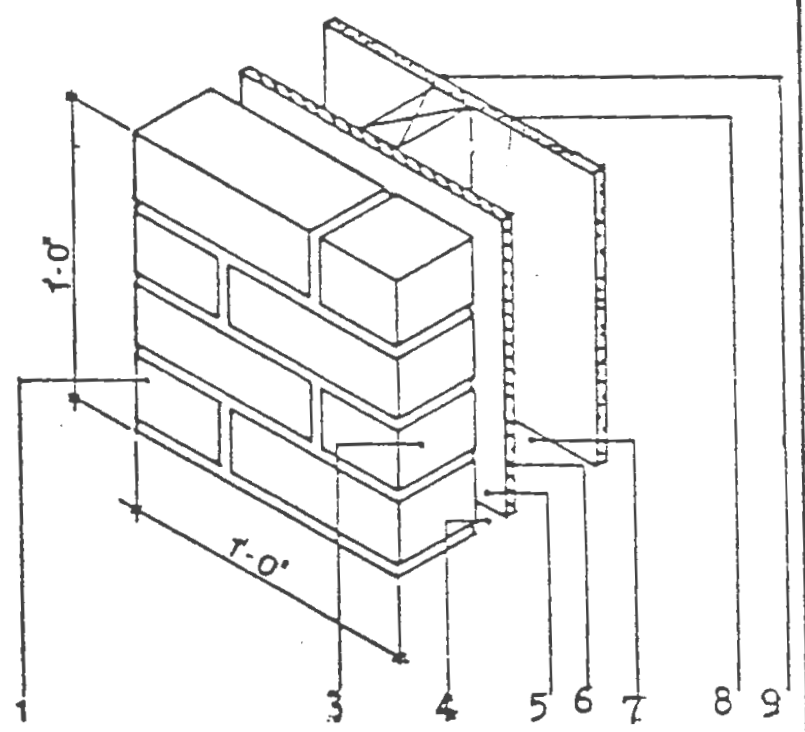

WOOD FRAME WALLS

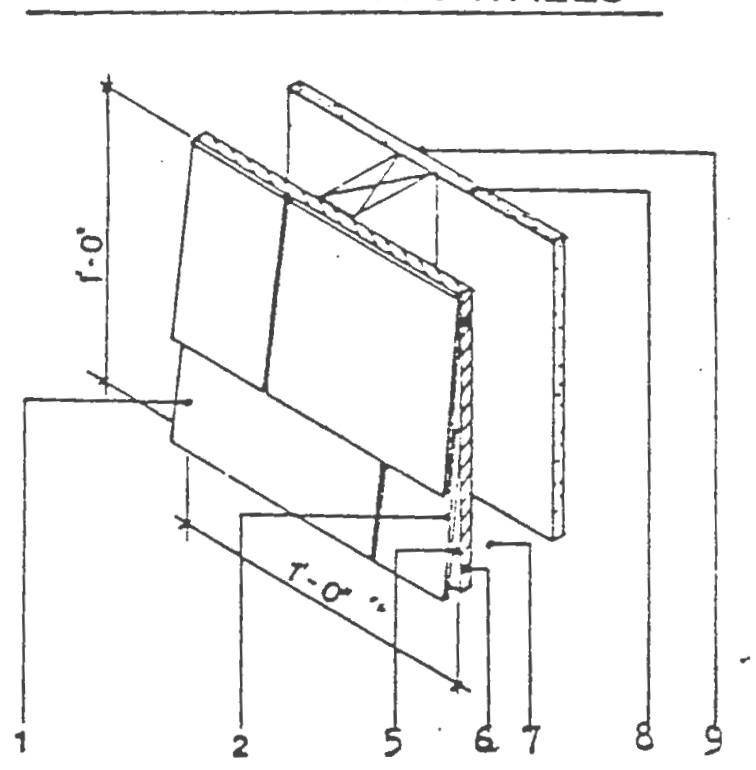

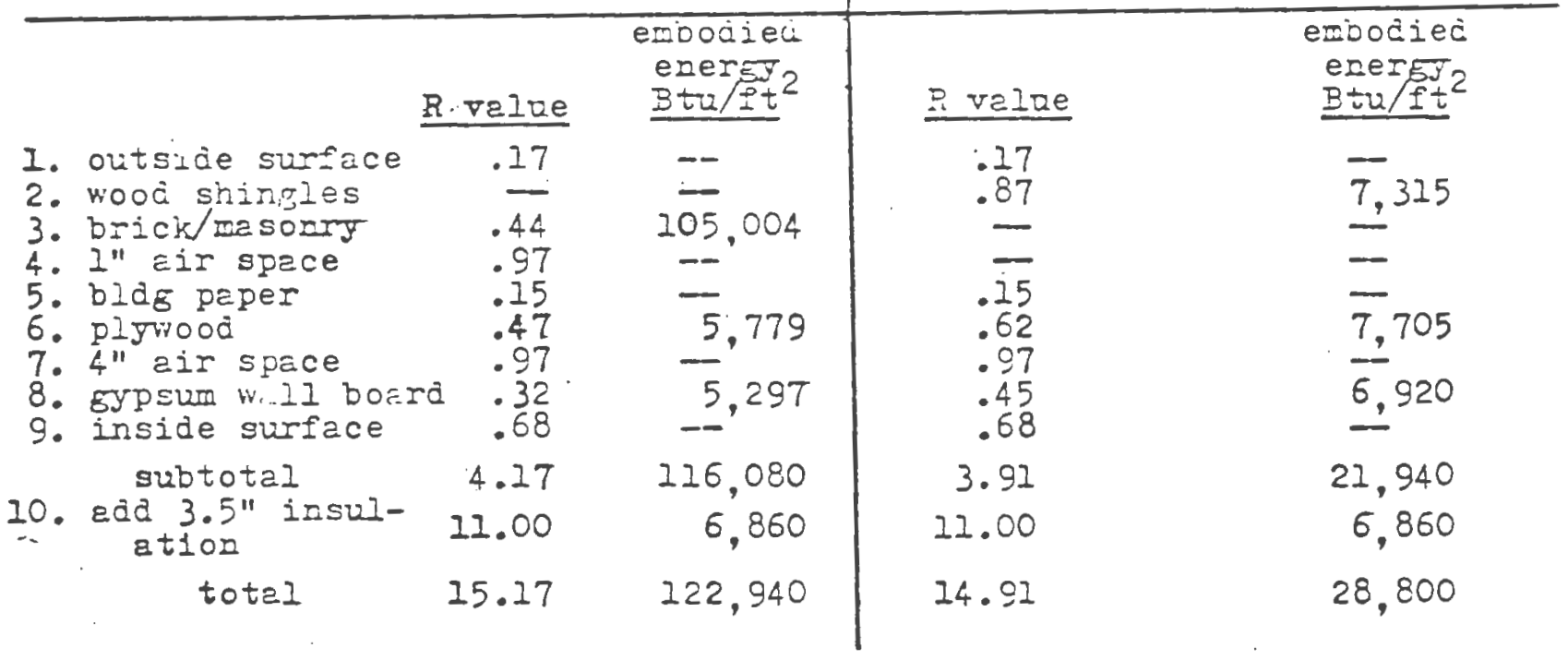

note: Difference in figures for plywood and gypsum wall board due to thichess of material required for the two types of construction.

Bource:Table derived fron, Hannon Segal, Stein. Serber, Enerzy Use for Buildire Constructicn, (Urbane-Chimpaign, Ill.: Dater researca Grolip, venter for favanced Computation, University of Illinois, ?ebruary 1977) pp. 96,97. 


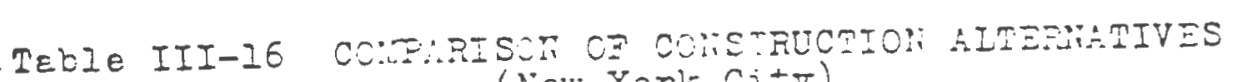

(

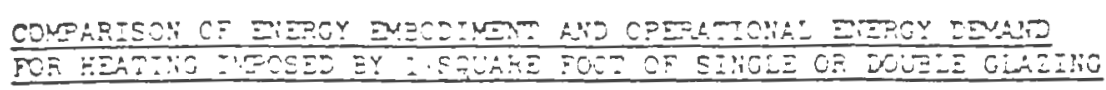

\begin{tabular}{|c|c|c|c|c|c|}
\hline \multirow{4}{*}{ Cless: } & & & $\begin{array}{c}\text { I SF Ebod: } \\
\text { Et } 4\end{array}$ & UfFetor & 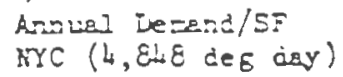 \\
\hline & a) & Sinale aless & 15,430 & 1.23 & $131,4778: 8$ \\
\hline & b) & Double with + & 30,860 & .65 & $75,528=4$ \\
\hline & c) & Double vith sp & 30.860 & .58 & 67,484 Btu \\
\hline
\end{tabular}

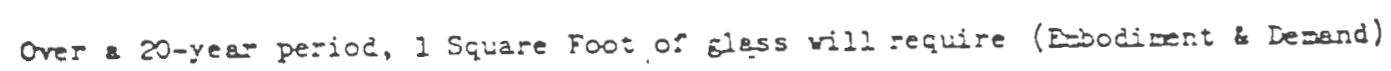

no. 6 ruel 0 il

Equivalent (Eal)
a) Single gless:
2.64 million Btu
27.6
b) Double vith :" sp
2.54 miL1100
10.3
c) Double with is" sp
$1.38=51100$
9.2

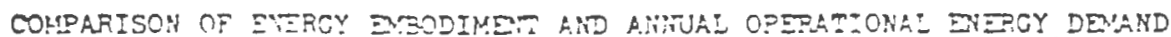

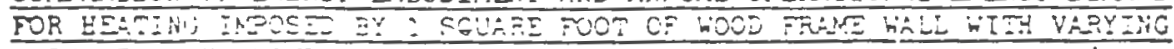

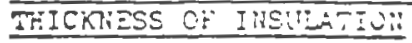

\begin{tabular}{|c|c|c|c|c|c|c|c|}
\hline $\begin{array}{l}\text { Mominal } \\
\text { Hell } \\
\text { Thickness }\end{array}$ & $\begin{array}{l}\text { Type } \\
\text { or } \\
\text { Framine }\end{array}$ & Insul. & UfFactor & $\begin{array}{l}\text { Eabodied } \\
\text { BerEy } \\
(\Xi \pm u)\end{array}$ & $\begin{array}{l}\text { Annuel } \\
\text { Demand } \\
\text { (Btu) }\end{array}$ & $\begin{array}{l}\text { Total Eneray } \\
\text { Consuned Over } \\
20 \text { Years (Etu) }\end{array}$ & $\begin{array}{l}\text { no. } 6 \text { ruel } \\
\text {. Oil. } \\
\text { Equivalent } \\
\text { (Cal) }\end{array}$ \\
\hline
\end{tabular}

Brick Veneer Walls

$\begin{array}{llllllll}20^{n} & 2 \times 4 \mathrm{e} 16^{n} & 0 & .24 & 219,566 & 27,924 & 678,046 & 4.52 \\ 10^{\circ} & 2 \times 4 \mathrm{e} 16^{n} & 32^{\prime \prime} & .085 & 126,4.26 & 9,889 & 324,206 & 2.16\end{array}$

Solagled Kells

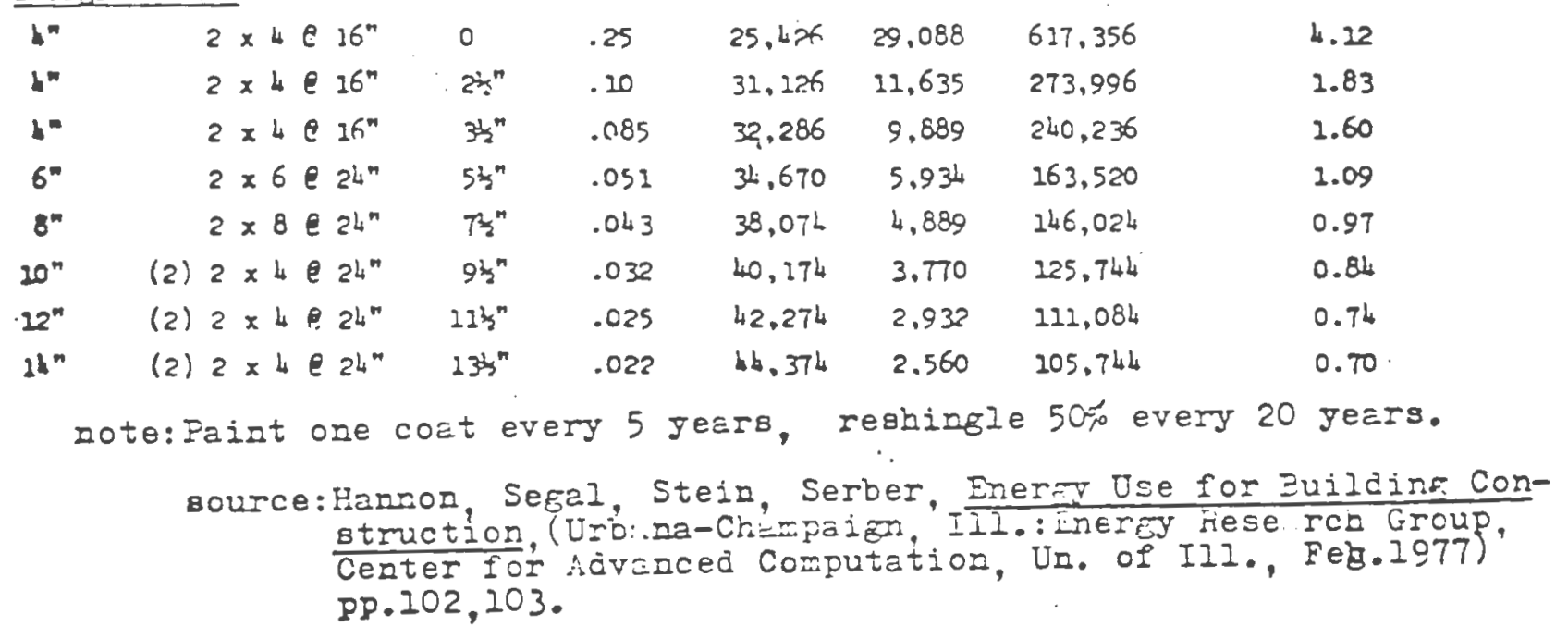




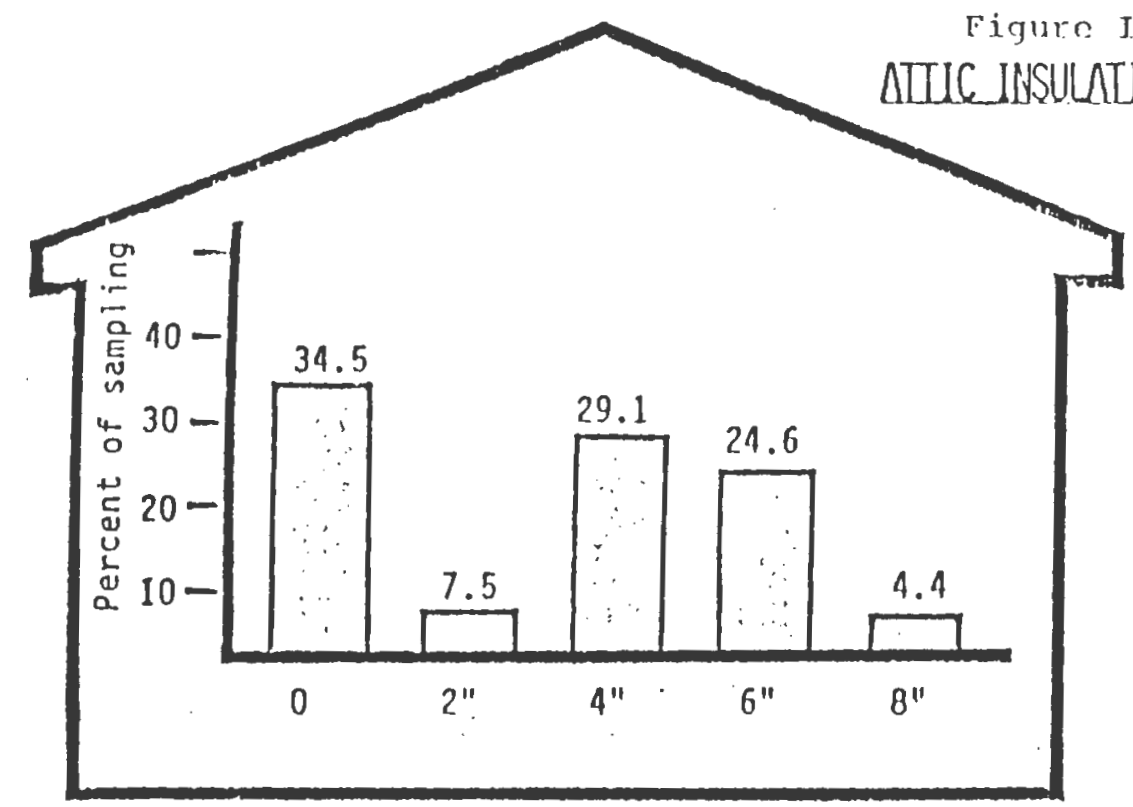

IOMES BUILT BEFORE 1920
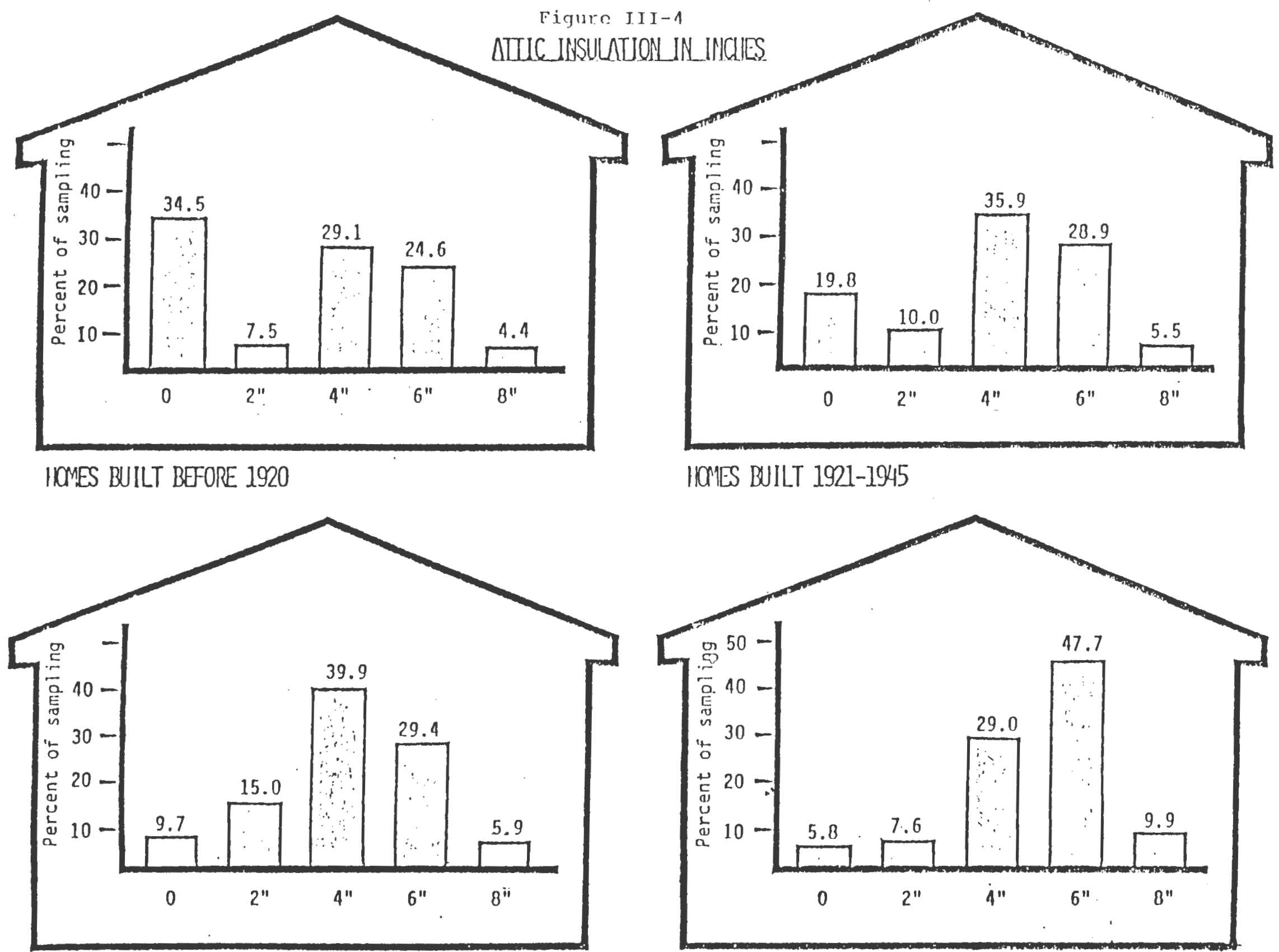

HOMES BUILT 1946-1965

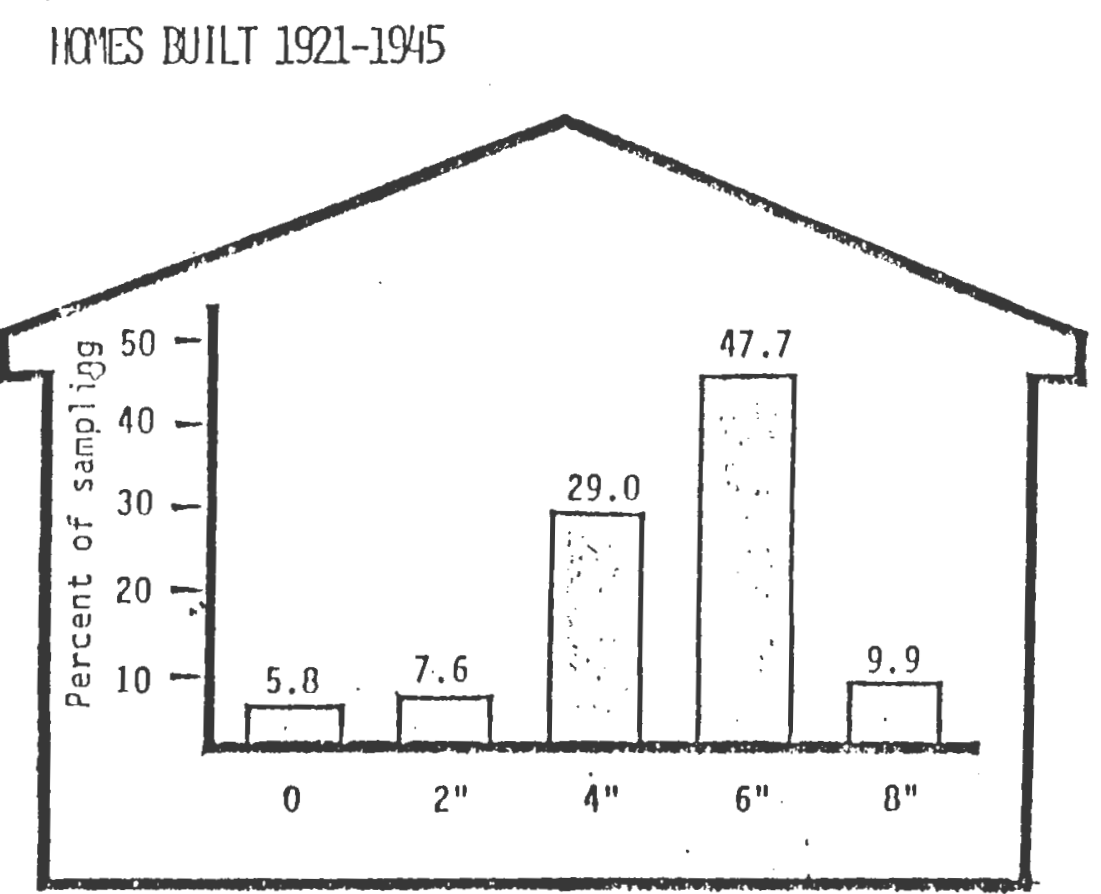


TabIe III-I7 ENERGY USE IN EISTIM NEW YORK ONICE BUIDIIGS

\begin{tabular}{|c|c|c|c|c|c|}
\hline Dates & $\begin{array}{l}\text { No. of } \\
\text { Bldgs. }\end{array}$ & $\begin{array}{l}8 \text { of } \\
\text { Bldgs. }\end{array}$ & $\begin{array}{l}\text { of } \\
\text { Area } \\
\end{array}$ & $\begin{array}{l}\text { Energy } \\
\text { Consumption } \\
\left.\text { (Btu } \times 10^{3}\right)\end{array}$ & $\begin{array}{l}\text { Average } \\
\text { Consumption }\end{array}$ \\
\hline $\begin{array}{c}\text { Before } \\
1900\end{array}$ & 3 & 6.8 & 1.1 & . $83-115$ & 95 \\
\hline $\begin{array}{l}1901 \\
1919\end{array}$ & 8 & 18.2 & 12.8 & $76-135$ & 105 \\
\hline $\begin{array}{l}1920 \\
1940\end{array}$ & 18 & 40.9 & 28.3 & $68-223$ & 109 \\
\hline $\begin{array}{l}1941 \\
1962\end{array}$ & 12 & $: 27.3$ & 36.2 & $66-198$ & 126 \\
\hline $\begin{array}{c}1962 \\
1970\end{array}-$ & 3 & 6.8 & 21.6 & $78-163$ & 115 \\
\hline
\end{tabular}

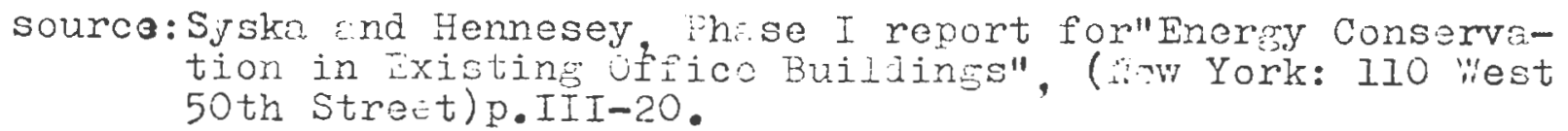


per $f t^{2}$ as compared to $240,256^{\circ}$ in the wood frame construction. The option of reducing glass area, which was considered to be an energy efficient alternative in the previous section on energy embodiment, also is shown to be the wise alternative from the point fo view of thermal performance of materials as is shown in Table III-6.

The most likely targets for energy conservation programs in existing buildings are those which have walls that are constructed with materials possessing poor thermal performance. Many commercial buildings, particularly supermarkets, chain stores, and public buildings are constructed with thermally inefficient brick, cinder block, etc. Figure III-4 illastrates that older homes are typically underinsulated. Conversely, Table III-17 shows that in office buildings older structures are more energy efficient.

Street surveys of structures in conjunction with mailout survey results is a method which can be used to assess the energy reduction opportunities in the residential/commercial building sector of the community. A sample questionnaire for conducting mail-out or phone surveys to determine insulation levels and general thermal efficiency of residences by age, size, location and other characteristics is included in the appendix. A sample structure street-survey questionnaire is included in the appendix as wel1. The street survey would be used in the field to inventory the condition of building stock. These surveys are typically done by housing authorities, redevelopment agencies, and community development agencies to establish base data for improvements to be undertaken in pro- 
grams. Including additional information regarding the age of structure and the construction materials used in the shell would take very little extra time and would provide valuable information for the formulation of energy conservation programs. Matching the street-survey inventory of structures with the results of a survey of a sample of buildings in each building category will provide information to help in targeting programs.

\section{CONCLUSION}

Chapter three has dealt with energy savings available through conscientious and informed selection of materials for use in construction. The performance of building materials as well as the energy embodied in materials have implications for the most efficient use of energy resources. Through the application of tables and figures enclosed in this chapter and its corresponding appendix the energy implications of specific decisions about the physical growth of the community can be determined. Also, through other information which has been presented in this chapter, a more generalized picture of the implications for energy and approaches to community energy planning have been conveyed. Finally, planning and research tools have been presented that can help give the planner insight to the energy situation, both in terms of its use and the attitudes related to it in the community, and guide him toward an appropriate response in plans, programs, and recommendations to decision makers. Whereas this chapter has primarily examined the buildings sector and approaches to analyzing it, the next chapter will look at the overall community and the linkages among it and portray energy implications in a less quantifiable manner. 


\section{CHAPTER III}

\section{Footnotes}

It would be inappropriate for this study to dwell upon research methods. However, for further information see, Readings in Evaluation Research, ed. Francis G. Caro, New York: Russel Sage Foundation, 1975): The Language of Social Research, ed. Paul F. Lazarsfeld and Norris Rosenberg, (New Fork: The Free Press).

${ }^{2}$ The most appropriate document to this discussion is, U.S. Department of Commerce, Bureau of the Census, Annual Survey of Manufacturers. For a listing of other energy data compiled by the Bureau of the Census see Appendix $C$.

${ }^{3}$ In a survey of the nine most energy consumptive/energy intensive industries in Rhode Island which was conducted by the Governor's Energy Office in the summer of 1978,78 percent of the firms responding considered coping with energy costs to be important to the success of their business, "Industrial Sector Energy Conservation Survey", Governor's Energy Office, July 1978 .

${ }^{4}$ Rhode Island Director of Manufacturers, Rhode Island Department of Economic Development, 1978.

${ }^{5}$ The U.S. Bureau of Census defines value added as follows: "This measure of manufacturing activity is derived by subtracting the cost of materials, supplies, containers, fuels, purchased electricity, and contract work from the value of shipments for products manufactured plus receipts for services rendered. The result of this calculation is then adjusted by the addition of value added by merchandising operations (that is the difference between the sales value and cost of merchandise sold without further manufacture, processing, or assembly) plus the net change in finished goods and work in progress inventories between the beginning and end of the year." See Appendix C for a complete list of industries energy consumption by percent value added for New England States and the overall U.S.

6 The average cost of a million BTU's of energy in New England is $\$ 3.94$. This figure can be applied to the data in this table to determine the part of the dollar which goes to energy in New England industry groups.

7 Note that by following these guidelines the Governor's Energy Office questionnaire to industry had a 27.6 percent response rate.

${ }^{8}$ Hannon, Segal, Stein, Serber, Energy Use for Building Construction, (Urbana-Champaign, Il1. : Energy Research Group, Center for Advanced Computation, University of I11inois, February 1977), abstract. 
9 Ibid.

10 Ibid.

${ }^{11}$ See Appendix $C$ for more information regarding the energy intensity of glass and other building materials.

12 Hannon, Segal, Stein, Serber, Energy Use for Building Construction, (Urbana-Champaign, I11.: Energy Research Group, Center for Advanced Computation, University of Illinois, February 1977) p. 11.

${ }^{13}$ Transportation Research Board, Bituminous Emulsions for Highway Pavements, (Washington, D.C.: Transportation Research Board, 1975) p. 5 .

${ }^{14}$ These three points are addressed in, Ibid.

${ }^{15}$ American Society for Testing and Materials Standard Specification for Hot-Mixed Hot-Laid Emulsified Asphalt Paving Mixtures specifies this temperature range.

${ }^{16}$ The National Asphalt Paving Association has prepared a report on fuel conservation. 


\section{CHAPTER IV \\ ENERGY AND URBAN FORM \\ Introduction}

As was presented in the introduction to Chapter III, the planner's ability to serve a useful function relative to community based energy planning is largely dependent upon two things. They are:

1. his ability to assemble meaningful and valid information

2. his ability to apply this information to plan development and implementation

This chapter, Chapter IV, will continue to address these considerations by picking up where Chapter III left off. While Chapter III focused on energy consumed in the manufacture of products, in construction, and in the operation of buildings as if they were isolated entities, Chapter IV will address community energy consumption holistically. This chapter addresses energy in the context of the overall physical development of the community. It examines land use and its implications for community energy consumption. The chapter examines site design, land use densịty, building juxaposition, and the situation of land use types. It also explores various design components and considerations, primarily related to transportation, which have implications for community energy consumption.

Chapter IV will be less oriented toward facts and primary data than Chapter III. Although many facts and data have been collected with regard to subjects presented in Chapter III, there has been little such activity with relation to subjects 
in Chapter IV. Information in this chapter is primarily useful as a qualatative guide rather than as a basis for a specific quantitative analysis.

Space and form are the key concepts examined in the chapter. Space is important because the manner in which the space is used has direct bearing on the amounts of energy which will be used in communication across that space. The efficient consolidation of space will result in the most efficient use of energy. Form refers to the urban landscape and natural relief, which combined, compose the topography of the community. Form is an inportant consideration from an energy standpoint because natural terrain affords opportunities for energy conscientious community growth that can be realized through proper design of the man made form. In this chapter the concept of space primarily applies to transportation and infrastructure within the community and the concept of form primarily refers to building and site design.

\section{SPATIAL CONSIDERATIONS}

\section{Overview}

The energy for communication ${ }^{1}$ is one of the most fundamental aspects of community energy use and can be understood intuitively, yet quantitative data regarding the specific energy use for different land use patters is scarce. Intuitively, one understands that time and energy are required to transport something between two points in space. One can also readily accept the fact that the greater the space between two points the greater the costs for communication between them. An entire body of economic theory is constructed 
with this principal as its central tenet. Location theory ${ }^{2}$ maintains that the space between two points comprise the "friction of distance" and the costs of overcoming the friction of distance is central in determining the location of points in space and the manner in which they relate to one another. Access to needed commodities becomes the controlling factor in the make up of our urban landscape, according to location theory. Access to raw materials and to markets becomes the controlling factor to industry. Access to markets becomes the controlling factor to commercial establishments. And access to goods and services is the controlling factor to households. Overcoming the friction of distance has costs attributed to it. The friction of distance can be diminished in one of two ways. It can be diminished by increasing our ability to overcome distances or by decreasing the distance. In our modern society technology has allowed us to greatly reduce the friction of distance by increasing our ability to overcome it. Transport and communication advancements of the past two centuries, and the twentieth century in particular, have allowed us to greatly decrease the friction of distance. This factor is reflected in the nature of our urban landscape since the turn of the twentieth century. The advent of streetcars in the late nineteenth century gave rise to suburbs and facilitated the economic prosperity of all of society. ${ }^{3}$ The advent of the automobile resulted in the further decentralization of our cities and the creation of urban sprawl patterns of development. The costs of overcoming the friction of distance were decreasing thanks to technology. 
The technology which enabled society to reduce the friction of distance required markedly different inputs than did previous modes of transportation. The new means of communication and transport require substantial amounts of fuel and energy in their operation and manufacture. Table IV-1 illustrates the increase in energy consumption within the transportation sector which has occured in the United States, with transportation currently accounting for 25 percent of all energy use. The modern transportation technologies have permitted us to overcome greater distances at less costs than previous transportation modes. However, it has also created a landscape which is highly consumptive of energy and greatly dependent upon a minimal friction of distance. Increased costs of energy will have the effect of increasing the friction of distance and leave us with a fixed pattern of land use which is inappropriate, in view of the increased costs of overcoming the friction of distance.

In taking this discussion out of the realm of the $a b-$ stract, the subject matter relates to modes of transport for freight, people, power, water, and anything that must be moved. On the macro scale, nationally and internationally, the modes of transportation that come to mind are shipping, air transport, pipelines, long haul trucking, and rail. Table IV-2 portrays some of the characteristics of these modes of transportation. Note that under the costs column, fixed cost for rail and pipelines are high. This is in large part due to the high energy embodiment of these transportation modes. For example, it has been calculated that the Bay Area Rapid Transit 
Taよle IV-2 COYPAEATIVE CHERATERISTICS OE UODAL SYSTENS

(

\begin{tabular}{|c|c|c|c|c|c|c|c|}
\hline Aiose & $\cos 15$ & $\begin{array}{l}\text { Unit Cosi }(r .4 i t e) \\
\left\{R_{a i} \mid-9.0\right)\end{array}$ & Distance & Fites & $\begin{array}{l}\text { Choracieristic } \\
\text { Good: }\end{array}$ & Disineiton & Drembecks \\
\hline Faitroad & 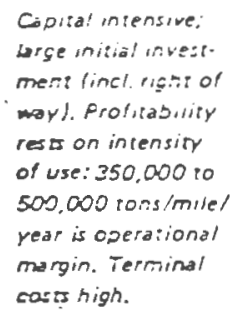 & 1.0 & $\begin{array}{l}\text { Inereasing } \\
\text { effec:ivenez } \\
\text { wirh dength of } \\
\text { houl. Large } \\
\text { shipments } \\
\text { cheaper oy } \\
\text { tong or short } \\
\text { houl. }\end{array}$ & 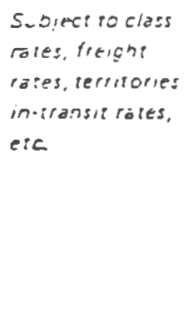 & $\begin{array}{l}\text { thineráts: un. } \\
\text { processed } \\
\text { ag"ie. prosuct:. } \\
\text { building mais. } \\
\text { chemicals. } \\
\text { fassira minor. }\end{array}$ & $\begin{array}{l}\text { Large volumes } \\
\text { ef buir goses } \\
\text { in comparailvely } \\
\text { short sime at } \\
\text { low costs. }\end{array}$ & 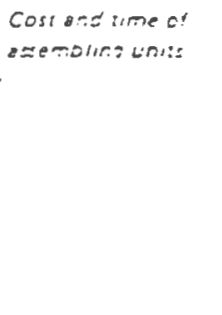 \\
\hline wrtenways & $\begin{array}{l}\text { Investment low, } \\
\text { especially where } \\
\text { natural waterways } \\
\text { utilized. } \\
\text { Terminal and hand. } \\
\text { ling costs several } \\
\text { times line haul costs }\end{array}$ & 0.29 & $\begin{array}{l}\text { increasing } \\
\text { effecriveness } \\
\text { wirh lengeh } \\
\text { of haul. }\end{array}$ & & $\begin{array}{l}\text { Marine: semi- } \\
\text { finished and } \\
\text { finished prod. } \\
\text { uets. Inland: } \\
\text { bulk row goods- } \\
\text { coke, cool, oil. } \\
\text { grain, sand. } \\
\text { groved, cement. } \\
\text { Pass'rs } \\
\text { negligible. }\end{array}$ & $\begin{array}{l}\text { Low freight } \\
\text { rates; slow } \\
\text { speet; spec. of } \\
\text { goods carriage. } \\
=\end{array}$ & Slow speed. \\
\hline Motor Transport & $\begin{array}{l}\text { Fixed costa negli- } \\
\text { gible. Operates on } \\
\text { omall margins - } \\
\text { operating costs } \\
\text { high: rehicle } \\
\text { turnover high. }\end{array}$ & 4.5 & $\begin{array}{l}\text { Short hauls, less } \\
\text { cost/y than ratl. } \\
\text { wide areal } \\
\text { coverage. }\end{array}$ & $\begin{array}{l}\text { Railacis as } \\
\text { price leader. }\end{array}$ & $\begin{array}{l}\text { Peristable } \\
\text { gooos, lumber. } \\
\text { Pass'rs } \\
\text { important. }\end{array}$ & $\begin{array}{l}\text { Lighr loass. } \\
\text { short distances, } \\
\text { short time. } \\
\text { Flexible and } \\
\text { conveniert. } \\
\text { Improved serv. } \\
\text { iec. Minimizes } \\
\text { distribution } \\
\text { costs. }\end{array}$ & 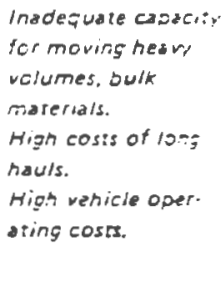 \\
\hline Air Trensport & $\begin{array}{l}\text { Fixed costs low. } \\
\text { Investment in } \\
\text { stock very high. } \\
\text { Terminal, tske-off } \\
\text { corts, high. }\end{array}$ & 16.3 & $\begin{array}{l}\text { Long houls. } \\
\text { economy with } \\
\text { distonce. }\end{array}$ & $\begin{array}{l}\text { Rates set by } \\
\text { national ond } \\
\text { international } \\
\text { regulations }\end{array}$ & $\begin{array}{l}\text { Pass'rs } \\
\text { dominans. } \\
\text { Perishable. } \\
\text { light meight. } \\
\text { high walue } \\
\text { poods. }\end{array}$ & Sored. & Very high costs \\
\hline Pipelines & $\begin{array}{l}\text { Fixed cosss high. } \\
\text { Lorge economies } \\
\text { etrough diometer } \\
\text { of pipe. Corss } \\
\text { incresse a/most } \\
\text { directiy with } \\
\text { distona. Viscosity } \\
\text { addr costs. }\end{array}$ & 0.21 & $\begin{array}{l}\text { Long houl in } \\
\text { ow/k. }\end{array}$ & & $\begin{array}{l}\text { Crude dil and } \\
\text { perroleum } \\
\text { products in } \\
\text { wroe volume. } \\
\text { Notural gas. } \\
\text { Same solids. }\end{array}$ & $\begin{array}{l}\text { Bulk movement } \\
\text { of liquids. }\end{array}$ & $\begin{array}{l}\text { Restricted com. } \\
\text { matity use. } \\
\text { Regular flow and } \\
\text { demend needed. } \\
\text { Lorpe market. }\end{array}$ \\
\hline
\end{tabular}

- In Eurode, passenger revenues usualiy excred freighi revenues.

3. Gass rates. The Interstate Commerce Commission (l.C.C.) authorizes rates applicatle to ilems moving in small quantities. These rates vary for thirty classes. Thus a commodity in class 400 has four firnes the base rate $(100)$. while the rate for cless 13 would be 13 percent of the base rate.

4. Commodity rates. These are specific retes allowed by the I.C.C. for goods moving in large auantities between specific origins and destinoticns. They are the retes commonly used for the great majority of freight.

5. In-tansit rates. These are special privilezes granted by the l.C.C. that aliow goods to truvel at on intial raw freight rate, despite intemiediate processing. Tnus reilrose 
System's construction consumed almost half of what it will need in energy for fifty years of operation. ${ }^{4}$ Table III-4 (Chapter III), Iists petroleum pipelines as the most energy intensive construction sector. Of the top ten energy intensive activities six of them are related to energy production or transportation of energy. Table IV-3 and Figure IV-l chart the transport of energy in the U.S. by various modes including rail, motor carrier, waterway, and pipeline. As these figures bear witness, a large and increasing amount of energy is required to transport energy. Overall, freight has been estimated to account for about nine percent of total U.S. energy consumption, and about one third of total consumption in the transportation sector. 5

Facts bear out that over the years changes in the land use of this country correspond with increased energy use by generating more freight transportation, longer hauls, and by greater use of more energy intensive trucks. Since 1939 all land freight modes have markedly increased their total ton-miles of commodity haulage. The average length of haul for land freight transport has increased between 1963 and 1972 as illustrated in Table IV-4. Shifts in freight modes from rail to truck results in transport which is more energy intensive. Transport of freight by rail requires 714 BTU's per ton mile whereas transport by truck requires 2,280 BTU's per ton mile. 6

Spatial implications of Community Energy Consumption These macro changes are indicative of what is occuring within communities. Within communities the friction of distance refers to the energy costs associated with passenger 
Table IV-3 Tolal Crude Petrolcum and Prtroleum Products Transported in the U.S. by Method of Transportation, $1938 \cdot 1973$

\begin{tabular}{|c|c|c|c|c|c|c|c|c|c|}
\hline \multirow[b]{2}{*}{ Yenr } & \multicolumn{2}{|c|}{ Pinelines } & \multicolumn{2}{|c|}{ Water Canriers } & \multicolumn{2}{|c|}{ 'Trucks' } & \multicolumn{2}{|c|}{ Raj|ronds } & \multirow[b]{2}{*}{$\begin{array}{c}\text { Tolal } \\
\text { Tonk Carried }\end{array}$} \\
\hline & Tons Cnrrted & $\begin{array}{l}\text { Per Cent } \\
\text { of Total }\end{array}$ & Tons Cnrricd. & $\begin{array}{l}\text { Per Cent } \\
\text { of Total }\end{array}$ & Tous Cnrricd & $\begin{array}{l}\text { Per Cent } \\
\text { of Tolel }\end{array}$ & Tons Carricd & $\begin{array}{l}\text { Fer Cent } \\
\text { of Totsl }\end{array}$ & \\
\hline 1973 & $912,209,868$ & 46.67 & $421,205,848$ & 21.50 & $695,767,175$ & 30.11 & 29.730 .210 & 1.51 & $1,958,919,091$ \\
\hline $\begin{array}{l}1971 \\
1970\end{array}$ & $\begin{array}{l}806,671,000 \\
790,211,700\end{array}$ & $\begin{array}{l}16.90 \\
.16 .88\end{array}$ & $\begin{array}{l}116,792,000 \\
102,667,900\end{array}$ & $\begin{array}{l}21.21 \\
23.88\end{array}$ & $\begin{array}{l}170,700,000 \\
160,100,000\end{array}$ & $\begin{array}{l}27.37 \\
27.65\end{array}$ & $26,7,32,200$ & 1.59 & $\begin{array}{l}1,71 ! 1,812,900 \\
1,685,7 \cdot 11,800\end{array}$ \\
\hline 1969 & $\begin{array}{l}790,211,700 \\
769,612,000\end{array}$ & $\begin{array}{l}.16 .88 \\
46.81\end{array}$ & $\begin{array}{l}102,667,300 \\
378,862,700\end{array}$ & 23.88 & $458,000,000$ & 28.22 & $26,299,900$ & 1.62 & $1,622,774,600$ \\
\hline 1968 & $726,113,900$ & 10.17 & $361,002,600$ & 23.09 & $149,700,000$ & 28.76 & $26,25,1,200$ & 1.68 & $1,56.3,397,700$ \\
\hline 1967 & $679,321,600$ & 45.61 & $319,816,800$ & 23.60 & $13.3,600,000$ & 29.13 & $25,712,2,00$ & 1.73 & $1,188,473,600$ \\
\hline 1966 & $629,763,680$ & 41.81 & $332,877,019$ & 23.68 & $117,001,000$ & 29.67 & $25,809,500$ & 1.81 & $1,405,111,229$ \\
\hline 1965 & $687,795.180$ & 11.13 & $323,671,111$ & 21.17 & $385,180,600$ & 29.11 & $25,855,6,500$ & 1.90 & $1,322,804,094$ \\
\hline 1961 & $569,392,037$ & 41.61 & $321,806,229$ & 26.63 & $317,279,800$ & 27.65 & $27,381,079$ & 2.18 & $1,25,5,35,8,145$ \\
\hline 1963 & $621,149,137$ & 43.67 & $335,611,860$ & 28.06 & $312,58,3,106$ & 26.14 & $26,658,686$ & 2.23 & $1,196,002,789$ \\
\hline 1062 & $602,161,600$ & 13.36 & $329,734,368$ & 28.16 & $297,698,100$ & 25.69 & $28,855,082$ & 2.49 & $1,168,752,230$ \\
\hline 1961 & $181,170,056$ & 13.60 & $322,695,627$ & 29.06 & $273,619,6655$ & 21.61 & $29,961,2.33$ & 2.70 & $1,110,150,480$ \\
\hline 1960 & $168,109,682$ & 13.01 & $318,295,651$ & 29.22 . & $27 n, 375,26.3$ & 21.8 .3 & $32,057,110$ & 2.94 & $1,080,1: 17,729$ \\
\hline 1069 & $464,290,969$ & 13.22 & $310,09 n, 031$ & 28.80 & $206,612,261$ & $21, B 2$ & $33,3 \cdot 1,7,787$ & 3.10 & $1,074,375,011$ \\
\hline 1068 & $133,027,666$ & 12.67 & $298,656,025$ & 29.36 & $262,024,74.3$ & 21.78 & $3.3,470,881$ & -3.29 & $1,017,179,215$ \\
\hline 1967 & $111,078,169$ & 13.25 & $299,800,163$ & 29.10 & $212,331,559$ & 2.3 .76 & $36,643,971$ & 3.69 & $1,019,854,162$ \\
\hline 1956 & $111,386,180$ & 43.19 & $297,826,330$ & 29.31 & $2,15,960,622$ & 23.20 & $39,7[, 7,144$ & 3.92 & $1,011,930,276$ \\
\hline 1965 & $112,53.3 .395$ & 12.91 & $281,007,131$ & 29.50 & $222,601,360$ & 23.17 & $41,66,3,602$ & 4.33 & $960,808,391$ \\
\hline 1961 & 373.327 .262 & 12.67 & $268,521,812$ & 30.02 & $192,661,326$ & 21.96 & $42,5,3,4 \pi, 4 \pi$ & $4.86^{\circ}$ & 876.919 .886 \\
\hline 1953 & $369,112,335$ & 11.63 & $273,176,110$ & 31.70 & $181,025,131$ & 21.40 & $15,151,188$ & 6.27 & $862,6915,391$ \\
\hline 1952 & $337,591.210$ & 10.60 & $271,913,612$ & 33.06 & $171,711,5 \cap 88$ & 20.66 & $47,2011,626$ & 5.68 & $0.71,456,995$ \\
\hline 1951 & $321,667,831$ & 10.31 & $207,117,910$ & 33.20 & $16.3,5665,271$ & & $19,812,061$ & fi 19 & $805,194,100$ \\
\hline 1950 & $283,853,383$ & 38.82 & $252,765,749$ & 34.67 & $115,780,986$ & 19.93 & 18,8 B2,196 & 6.0 & 731.282 .311 \\
\hline 1919 & $261,023.767$ & 39.23 & $229,928,6055$ & 34.60 & $126,217,29.1$ & 18.97 & $18,199,099$ & 7.24 & 665,$36 ; 8,815$ \\
\hline 1948 & $262,452,631$ & 38.21 & $2.37,516,329$ & 31.61 & $120,897,800$ & 17.62 & $65,107,170$ & 9.6 .3 & $686,27.3,8.30$ \\
\hline 1917 & $237,879,551$ & 38.42 & $200,087,6600$ & 33.77 & $105,60,3,500$ & 17.05 & $66,6,38,6,69$ & 10.76 & $619,209,392$ \\
\hline $\begin{array}{l}1916 \\
19.45\end{array}$ & $222,266,138$ & 10.76 & $172,613,605$ & 31.61 & $88,852,600$ & & $61,6996,782$ & 11.31 & $645,329,125$ \\
\hline $\begin{array}{l}19.15 \\
1911\end{array}$ & $210.719,192$ & 11.06 & $112,198,332$ & 26.08 & $96,135,6,00$ & 17.60, & $07,003,250$ & 12.26 & $616,386,6,6,3$ \\
\hline $\begin{array}{l}1911 \\
1913\end{array}$ & $211,001,439$ & 15.21 & $117,688,301$ & 21.81 & $09,048,800$ & $18.36^{\circ}$ & $78,975,456$ & 14.63 & $6.39,713,9995$ \\
\hline 1942 & $190,391,113$ & 11.16 & $116,995,125$ & 21.19 & $76,171,600$ & 16.11 & $84,875,255$ & 17.91 & $473,733,623$ \\
\hline 1910 & $\begin{array}{l}1,172 \\
2,082\end{array}$ & & $\begin{array}{l}162,130,791 \\
119,691,153\end{array}$ & $\begin{array}{l}36.20 \\
38.78\end{array}$ & $\begin{array}{l}28,695,020 \\
21,819,000\end{array}$ & 5.67 & $\begin{array}{l}69,323,685 \\
60,797,161\end{array}$ & $\begin{array}{l}16.10 \\
16.70\end{array}$ & $\begin{array}{l}121,133,971 \\
305,742,696\end{array}$ \\
\hline 1839 & $\begin{array}{l}163,602,082 \\
147,631,680\end{array}$ & 39.11 & $118,061,169$ & $\begin{array}{l}38.78 \\
39.25\end{array}$ & $\begin{array}{l}21,819,000 \\
21,657,680\end{array}$ & 6.72 & $60,067,197$ & 15.92 & \\
\hline 1938 & $\begin{array}{l}19,031,080 \\
139,220,802\end{array}$ & 39.28 & $137,728,491$ & $\begin{array}{l}39.26 \\
38.86\end{array}$ & $\begin{array}{l}21,657,680 \\
20,538,060\end{array}$ & 6.80 & $60,833,147$ & 18.00 & $864,120,600$ \\
\hline
\end{tabular}




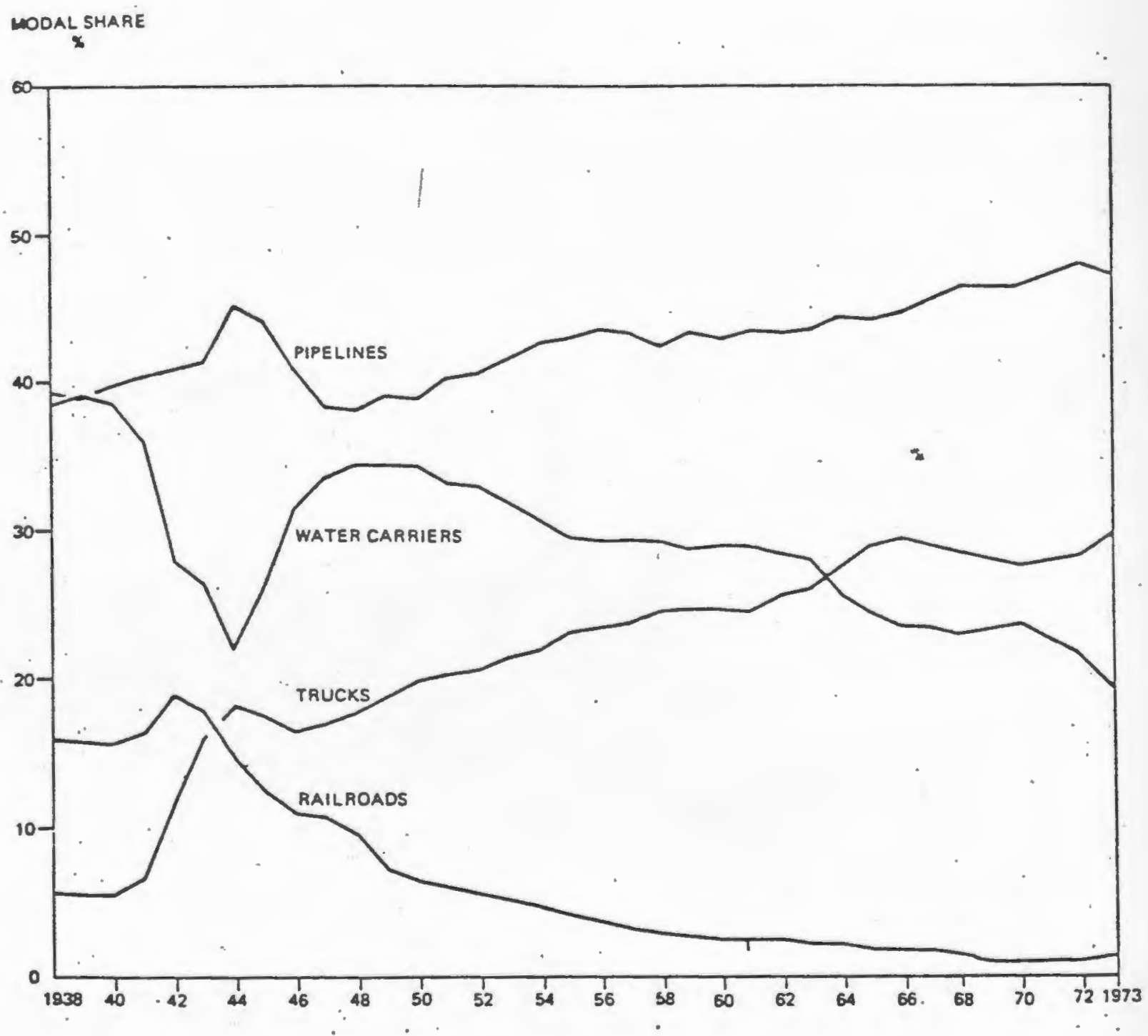

Modal Shares for Total Crude Petroleum and Petroleum Products Transported in the U.S., 1938.1973

source:U.S. Depertment of Iransportation. Enerer Statistice: A Supplement :o the Surrery of Mationi lransortetion Statistics, (U.S. Goverment rrintint Uffice, I975) 
T:bIe IV-4 AVERHGE IEHGGH OF FUL (c.ll com:odities)

mode

motor carriers

unregulated trucks rail
$1963 \quad \underline{1972}$

$273 \quad 306$

$137 \quad 166$

$527 \quad 577$

source:J.S. Burecu of the Census, 1972 Census of:Transporm tetion, T C72C2-8, Comrodity. Tr: nsportstion Survey Area Services. 
transport and utilities. Energy consumed to build and operate systems for transporting people, water, electricity, gas, wastes, and other commodities consumed within households comprise the community infrastructure. Reduction of energy embodied in and consumed in the operation of the infrastructure is a strategy that will reduce community energy dependence and contribute toward overall energy reductions in the macro scale discussed previously.

The facts about the energy savings available through sound community planning and increased density of development are varied but point out both some areas of opportunity and some areas where caution should be taken. The studies that have been done to this point indicate that most of the energy savings that will accrue from planned community development will occur in the transportation sector. In one study of all the savings available through increased density and planned development fifty-two percent of the energy reduction comes from the transportation sector. 7 Table IV-5 portrays the energy reductions that have been estimated in the transportation sector through various studies. Energy reductions of from twenty to fifty percent have been estimated. Increasing density and careful planning of communities reduces transportation energy requirements by decreasing distances of travel and by facilitating alternative modes of transportation to the automobile. Mixed land use provides low order goods ${ }^{8}$ in near proximity to households thus affording shorter trips and the opportunity to travel by foot, bicycle, or some other alternative mode. Careful planning and designing of streets and walkways, clustering of activity centers and services, and pro- 
TabIe IV-5 ESIIFIED TREFSEORT:TION EIVERGY REDUCTIOTS

study title

Capitol Area Flan (Sacramento)

Energy Thrift in Urban Tronsportation

Costs of Sprawl estimated enersy reduction

39 percent

20-35 percent

50 percent

* Estimetes of reàctions in energy consumption due to aensely plennea communities.

source:Fels end I"unson, "Energy Thrift in Urben Tr nsportetion: Options for the Future" in Robert H. WilIisms, The Energy Conservation Lapers, Reports prepered'for the Energy folicy Froject of the Ford Fouriation, (Cambriảge. liass.: Ballinger Publishing Co., 1975) p.7; Dennis Dickmin and Lee Windhiem, "Sacramento Can Do More With A Lot Iess Energy", Planning, vol. 43 no. II (Dec 1977) pp. 24and 25 ; Real Estate Reseurch Corporation, the Costs of Sprawl, prepared for the Council on Environmental Wiality, the Dep rtment of Housing and Urben Development, and the Environmental Protection Agency, $(1974)^{\prime} \mathrm{p} .145$. 
vision of supplementary facilities, such as facilities for securing bicycles, ${ }^{9}$ will contribute toward the overall reduction of the dependency on the use of the automobile. Density is also an important factor in the ability of an area to support transit.

Streets within the community should be designed to accomodate only the type of traffic which is suitable to the landuse of the area. Conflicts between different types of traffic should be eliminated. Pedestrians, bicycles, automobiles, and trucks should not come into conflict with one another. To avoid traffic hold ups and conflicts, through traffic should not mingle with local traffic. Local streets can be designed to discourage through traffic. There are several good references which address street design. Appendix $\mathrm{D}$ includes information from, Urban Planning and Design Criteria, (DeChiara and Koppelman) which defines and addresses specifications for street design including transportation networks for bicycles. Planning urban areas so that the need for conflicting traffic types is not generated is the other end of the design problem. 10

Community planning and design can help make the bicycle a very viable mode. Planners have defined bikeways according to three classes. A Class I bikeway is designed and designated exclusively for bicycles. Class I bikeways are often found in parks where they can serve only a recreational purpose and not as an integral part of the community transportation system. Class II bikeways provide semiexclusive use of a sidewalk or street by marking off a section which occasionally must be utilized by another transit modes such as a car crossing at an intersection. Class III bikeways are a right-of-way which is 
shared by bicyclists and motor vehicles and are generally indicated by roadway bike route signs. Table IV-6 portrays the costs associated with the construction of these facilities. 11

Mass transit requirements should be considered by the planner. In transit studies several factors have been determined to be important to the viabilit! of mass transit. According to a recent study these factors include proximity or distance of neighborhoods to nonresidential areas, the quality and cost of service, and the density of the point of origin (the resident trip end) and the nonresidential point of trip destination. Experts have been able to establish minimum residential densities required to support various types of transit. These densities are presented in Table IV-7 by type of transit. Density requirements will vary as depicted, according to some of the aforementioned factors. Community planners who are seeking to make mass transit part of the community should strive to attain appropriate densities called for by this table. Table IV- 8 portrays some other factors associated with transit modes including energy consumption, operation and maintenance costs, material consumption, and roadway space consumption. The favorability of mass transit over automobile transit is clear. Another study points out that the city bus and rail need only carry three to five times the auto's average occupancy to be competetive in energy consumed". 12 Communities that do not possess the necessary characteristics to support transit should undertake community planning for future development with the objective of attaining these necessary traits.

In areas where alternatives to the auto exist, the develop- 


\section{Table IV-6 BIEEriz COSTS}

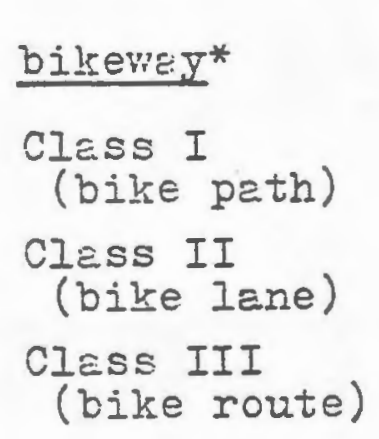

construction costs

(dollars per mile)

$\$ 20,000$ to $\$ 40,000$

$\$ 2,000$ to $\$ 4,000$

$\$ 500$ to $\$ 1,000$

* Sikerey types are defined in the tex-t of the chipter.

source: Carl Berkowitz, "The Bicycle", Frscticing Plenner, vol. 8 no. I (fíarch 1978) p.34. 


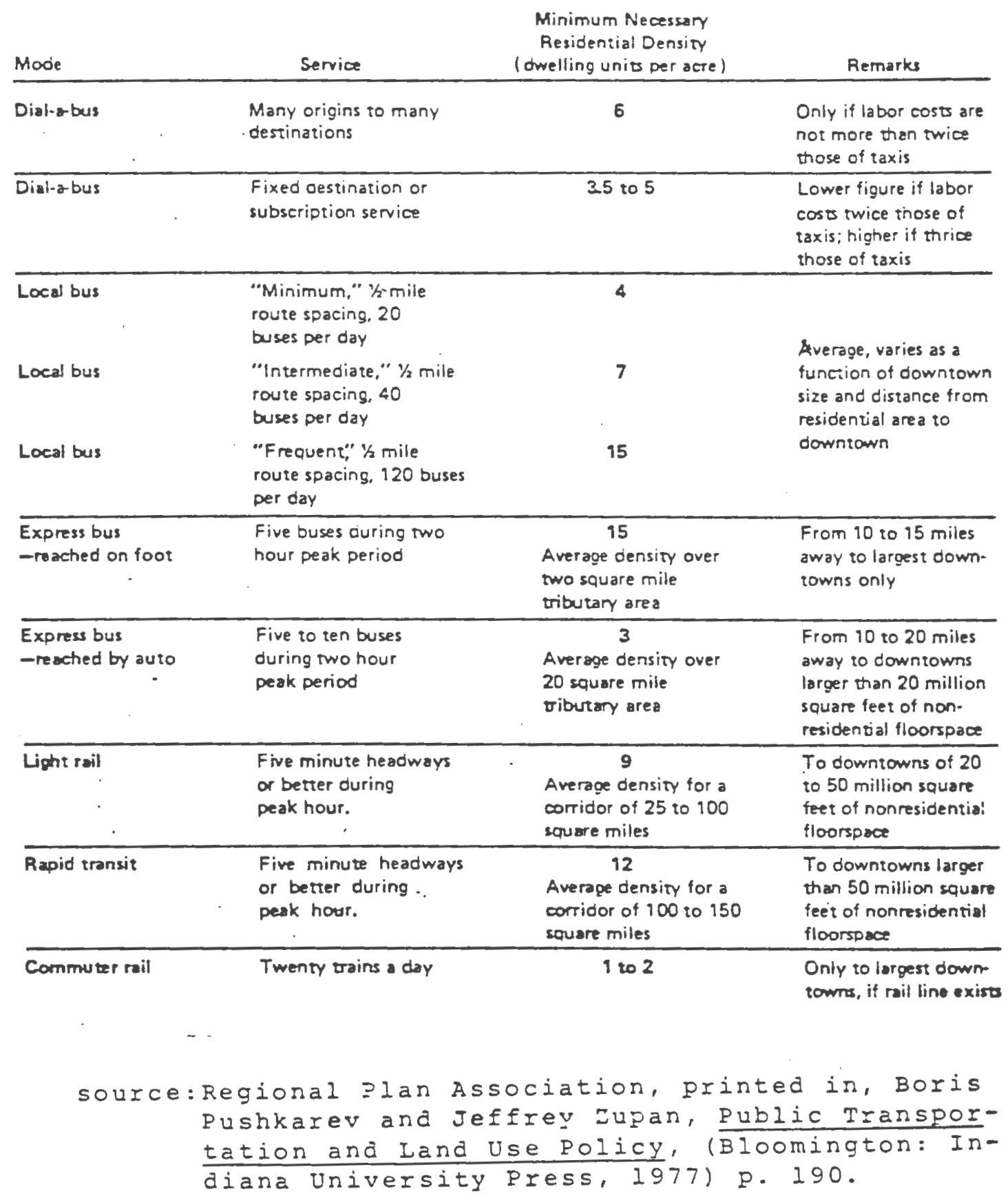


Table IV-8

Resource Use of Iruaportition Systerns

Exhibit woums the following owrog oceupancies (persons per whicle):

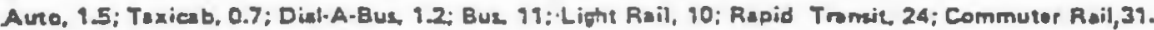
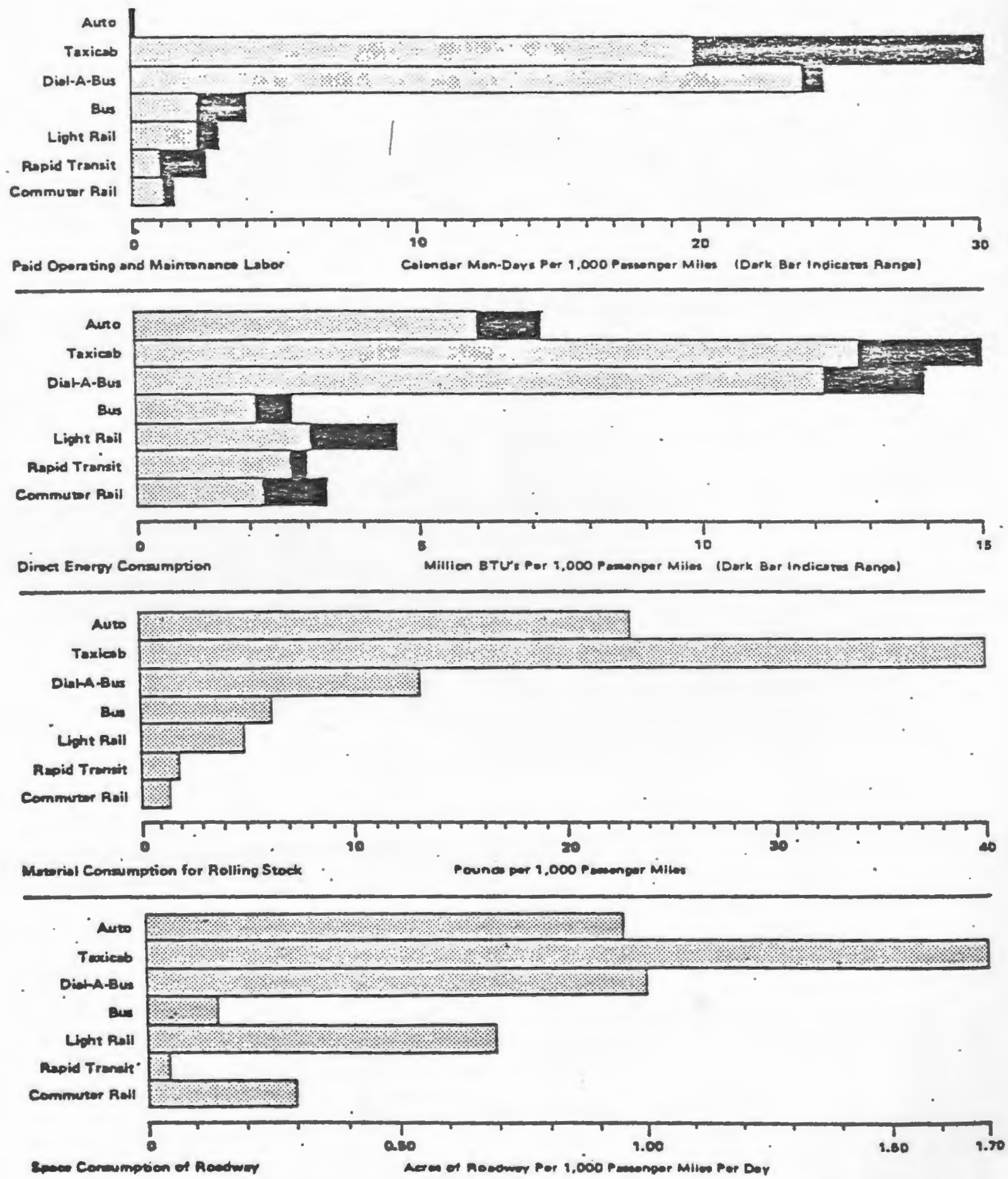

source:Pushkarev and Zupan, Public Transportation and Iand Use, (Bloomington:... On... Of.Indiana Press, 1977) p. 180. 
ment and adoption of an automobile parking management plan will support and reenforce these modes. ${ }^{13}$ Through a well thought out automobile parking management plan reduction in auto dependency can be induced which will serve to attain community objectives for air auality, traffic circulation, dontown commercial viability, and energy conserration. Strategies for parking management are aimed at the regulation of the supply of parking spaces, regulation of the cost of parking, and design of parking facilities. Although arailable data on actual energy reductions due to parking management programs is scarce, the value of increasing the relative attractiveness of modes alternative to auto transport is apparent. Ciaties which have adopted auto parking management plans, such as Boston, Pittsburgh, New York, San Francisco, and Hashington D.C., lay claim to energy conservation as one of its benefits. In Hashington D.C. it was found that a forty-two percent reduction in parking spaces resulted in a thirteen percent reduction in auto commuting. 14 A Council of Governments study determined that a two dollar daily surcharge on long term commercial parking would cause a fifteen percent reduction in vehicle miles traveled, a fourteen percent increase in commuter transit trips, and a daily savings of 23,481 gallons of gasoline. 15

Development of an appropriate and workable traffic management plan requires the community to commit itself to a research and planning process that will provide essential data from which to develop the plan. To gain an effective understanding of the existing parking situation the community should inventory and classify the parking spaces within the effected downtown area 
and identify the groups that have interests in the parking. In inventorying parking spaces, it is important to note the type (off street, on street, garage, lot,), nature and level of the rate (long term or short term), how much it is used when it is used, who uses it, its proximaty to traffic generators, and its proximaty to alternative transportation modes. When investigating groups that have interests in the parking facility it is important to note who owns the parking spaces, who pays for the parking (employer or employee for example), and the direct effect that the availability of parking has on politically strong intorest groups and economic sectors (merchants, powerful land holders). When inventorying parking the planner should develop a $\log$ sheet which addresses all of these factors for each parking facility such as in Figure IV-2.

An effective parking management plan will address all types of parking and will be aimed at the commuter. Realistic parking management programs will insure compensation of $10 t$ owners 16 when parking space reductions are involved and will charge the actual user directly and on a daily basis. This will insure that its adoption is politically feasible and insure that the program is impacting the proper target group for maximum effectiveness. Ensuring that sufficient parking and convenient parking is available to shoppers will keep merchants happy, will assist the downtown economy, and will save energy. Energy will be saved by curtailing or eliminating the need to search for a parking space. Providing convenient short term parking may require imposing before $10 \mathrm{a} . \mathrm{m}$. parking bans in areas or in a percentage of parking spaces, as was done in Boston. This will 


\section{Fisure IV-2 FARKIIG IITEIITGRY LOG SHEET}

TTEE OT P:RKING:

$$
\begin{aligned}
& \text { open lot with Ettendents } \\
& \text { _ gereme } \\
& \text { _ on street } \\
& \text { other(describe) }
\end{aligned}
$$

LCC.TION: (describe; bordering strests, access to which streets)

FroRIMAY TO TRTSIT: (describe, location of stops, type of trensit)

POXIHTY TO CBD: (describe, äistence)

FEES AND RATES:(describe fees and long term rates evailable)

\section{OIIER:}

OPEE:TOR:

\# OA SP.CES, TOT:L:

$\#$ OF SPACES FILIED AT 9:30 A.M.:

\%OF SF $\triangle C E S$ :

\# OI SPACIS FIILED AT 6:00 P.M.:

\% OF SPACES:

USERS:

employees of: (neme firms)

customers of: (nime firms)

PARKIIVG PAID BY:

$\begin{array}{ll}\text { erployer:. 100\% } \\ \text { employer } & 100 \% \\ \text { perker } & \\ \text { other } & \end{array}$


- prohibit commuters from using these spaces, because most commuters arrive at work prior to $10 \mathrm{a} \cdot \mathrm{m}$. , and make them available for short term parking.

The three strategies to parking management are supply, price, and design. Pricing strategies are aimed at making transportation alternatives to the automobile attractive in terms of comparative out of pocket costs. This can be accomplished by establishing rate structures which discourage long term parking or through taxation. Taxation has the advantage of making money available to the community to administer the program. Reducing the supply of parking will indirectly raise prices while also cutting down on the actual number:of spaces. Limiting supply on a temporal basis, such as before 10 a.m., is one approach. Limiting supply within a geographical area is another approach. Limiting parking to areas outside the immediate commercial area and forcing commuters to walk greater distances to their jobs will hamper the convenience of the automobile, one of the most important independent variables in the choice of transportation modes. Supply reduction programs should be oriented to allow parking owners to raise the price of parking to compensate for their loss in revenues. The design of parking facilities also has energy implications. Table IV-9 shows how the physical configuration of a parking facility can impact on the total vehicle miles traveled within the facility to obtain a parking space.

Any parking management plan or mass transit promotion program should take care to inform the intended target group and other affected parties of their alternatives and the benefits 
T: ble IV-G WRIING FACIUITY CONFIGURAIOTS

\section{$\triangle N D$ ETTRGY CUNSUTPTION}

\section{Facility Design}

\begin{tabular}{|c|c|c|c|}
\hline Physical Configuration" & $\begin{array}{l}\text { No. of } \\
\text { Stalls }\end{array}$ & $\begin{array}{c}\text { Sq. Ft } \\
\text { Per Stall }\end{array}$ & $\begin{array}{l}\text { Tatal Vehicle } \\
\text { Miles Per Day }\end{array}$ \\
\hline $\begin{array}{l}\text { 1. Split Level: one outside } \\
\text { bay offeet a half level in } \\
\text { height from the other three } \\
\text { bays. }\end{array}$ & 984 & 317 & 580 \\
\hline $\begin{array}{l}\text { 2. Double Helix: Sloping } \\
\text { floor configuration with a } \\
\text { double helix in the center } \\
\text { two bays for up and down } \\
\text { traffic. }\end{array}$ & 1000 & $\begin{array}{l}320 \\
\cdots \\
:\end{array}$ & 530 \\
\hline $\begin{array}{l}\text { 3. Express Ramp: Flat } \\
\text { floors with a double helical } \\
\text { spiral express ramp system } \\
\text { with an } 80 \text { foot diameter. }\end{array}$ & 990 & 347 & 405 \\
\hline
\end{tabular}

Source: Adapted from Charles M. Boldon, "Environmental Impact on Parking," Parking, January 1975, at 25.28.

a. Assumptions:
(i) Site is $215^{\circ}$ feet $\times 300$ feet.
(ii) Entrance at one corner, exit at another.
(iii) 9 foot stalls, bay width and parking angle determined by parking standards curve.
(iv) No driver recirculates to find empty stall.
(v) Lower level used for 500 short-term patrons (198 stalis $\times 2.58$ turnover rate).
(vi) Upper levels used for all day patrons 11.0 turnover rate).

\begin{tabular}{ccc}
\multicolumn{3}{c}{ Tarling Angle } \\
Angle & Bay Width & $\begin{array}{c}\text { Total Vehicle miles } \\
\text { Per Day }\end{array}$ \\
& & 308 \\
$90^{\circ}$ & $62^{\prime} 0^{\prime \prime b}$ & 498 \\
$70^{\circ}$ & $57^{\prime \prime}$ & 530 \\
$5712^{\circ} \mathrm{C}$ & $53^{\prime \prime}$ & 568 \\
$50^{\circ}$ & $51^{\prime \prime}$ &
\end{tabular}

Source: Adapted from Charles M. Boldon, "Environmental Impact on Parking," Parking, January 1975, at 28.

a. Based on Double Helix configuration. No. 2, Table 1.

b. Bay width of $62^{\prime}$ would require a larger lot than is available under previous assumptions.

c. Parking angle used in Double Helix configuration, No. 2., Table 1.
Stall Width
Confururation (See Table 1)

Split Level Double Helix

Express Ramp
Total Vehicles Miles/Day Savings From With 8 '8" Stall Width 9'0" Stall Widths

$\begin{array}{ll}562 & 18 \\ 516 & 14 \\ 395 & 10\end{array}$

Source: Adapted from Charles M. Boldon, "Environmental Impact on Parking," Parking, January 1975, at 28.

\footnotetext{
source: Printed in, Durwood J Zaelke, Jr., Energy Conservition and Urban irinsportation, (Eivironmentallaw Institutd)
} 
that can accrue to them. Commuters should be aware of alternate transportation modes available to them. Merchants should be aware of the benefits in convenience to shoppers that will accrue to them. Facility owners should be aware of the compensation they will have for reduced parking supply. Employers should be informed of the savings they can attain by not having to provide parking spaces, and may even be convinced to put some of this savings toward subsidizing employee transit trips.

Energy Embodied In Community Infrastructure

In addition to the energy required to move things about the community, energy embodied in these communication systems is also a significant consideration. Energy consumption for construction and embodied in materials was discussed in Chapter IV in detail. Table IV-10 depicts infrastructure requirements for six prototype neighborhoods which were presented by Real Estate Research Corporation in The Costs of Sprawl, a report prepared for the federal government. ${ }^{17}$ The report presents the costs of operation and resource utilization in neighborhoods and in communities composed of various mixtures of those neighborhoods. As Figure IV-3 shows, density sucessively increases in neighborhood types A through E. Neighborhood F is a combination of types A through E. As would be expected, the requirements for community infrastructure are less in the more densely developed neighborhoods. Table IV-11 depicts that the cost of providing infrastructure in the more densely developed neighborhoods is correspondingly less expensive. Table IV-12 illustrates that construction activities involved in providing 
Table IV-10

\section{NEIGHBORHOOD STREET AND UTILITY LENGTHS}

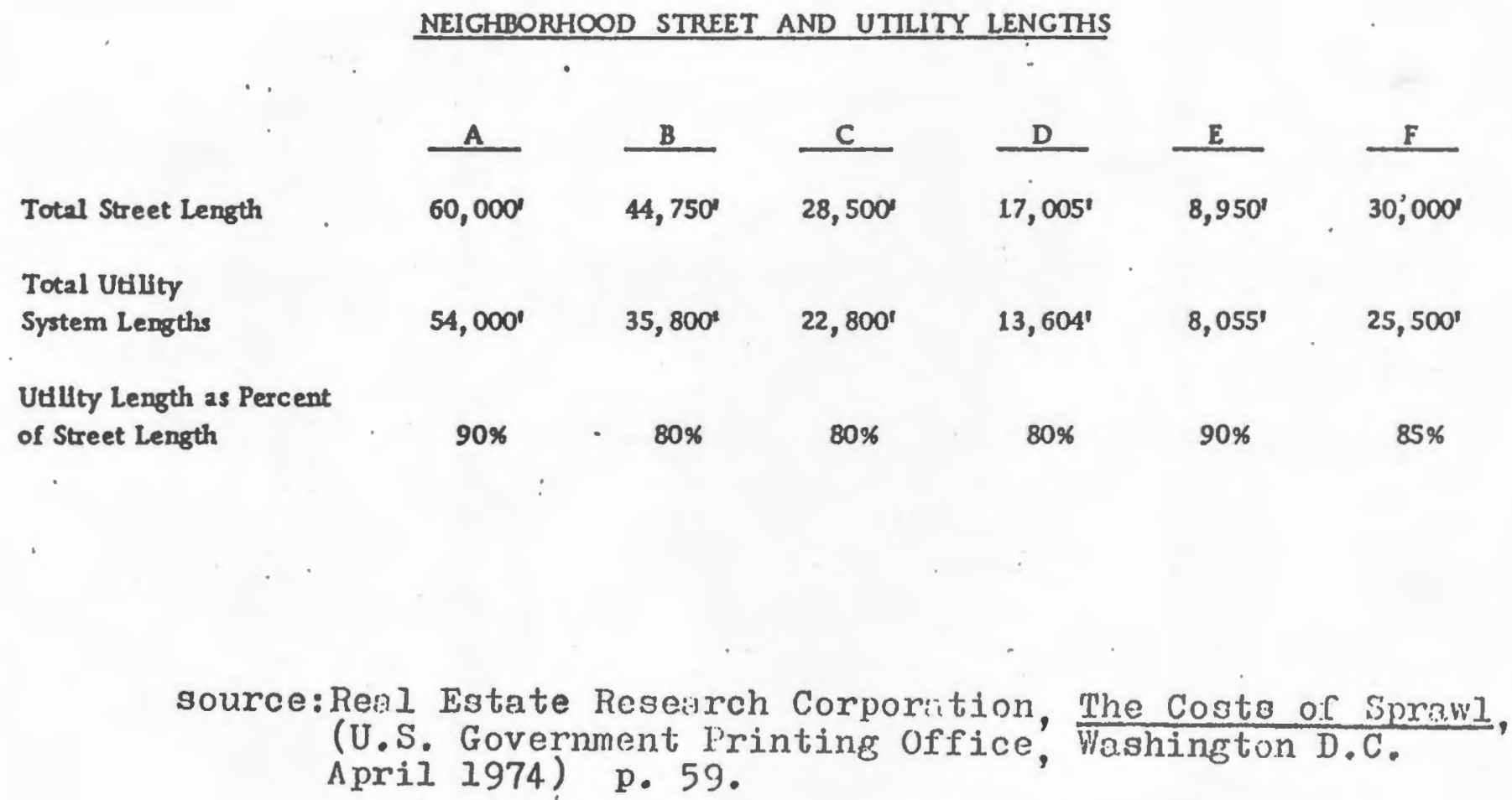


Popalation

Dwellag Unts

Acrenge

Developgerex

Petern

Hoosing Types

Enviroments

Comererdal
"Uhdroforiched" site wth typical eaviromental fearures; nox ine. specifie

Couverience certer, 7,500 square feet of bullitisg are2, 21,780 square Leet of land area.

\section{$\operatorname{Cos}=2$}

Popilation of 33,000, seme for all "commuaities

10,000 for exch cosarisy

6,000 acres for each comarmiry

Plened, sprawh, and cosbintion

(I) $20 \times$ mix; plazsed

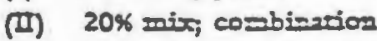

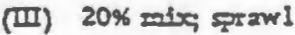

(IV) $75 \%$ siscle-farily corverional; plamed

(v) $75 \times$ single-fzesily coovedional, $25 \times$ single-fzesily chusere d; मаस

(vi) $10 \%$ aisle-family chrered, $20 \%$ rownhouses, 30\% wallk-ups, $40 \times$ hlgh-rise aparaers; planed

Sume as seighbonbood

(2) Sttp commercial developmen, 200,000 square feet of building cres, 1,056,000 square feet of lnod area

(b) Coner comoredal developmer, 240,000 square feet of bullding trea, 740,000 square feet of land are.

source: Real Estate Research Corporation, the Costs of sprawl, (J.S. Government Printing office, washington D.C., April 1974) P. 59. 
Tali le $\mid \mathrm{V}-11$

NEICITONIOCOR COST ANAIYSIS

UTIUTILS-CAFITAL AND DFERTING COST SIMAMIARUIS

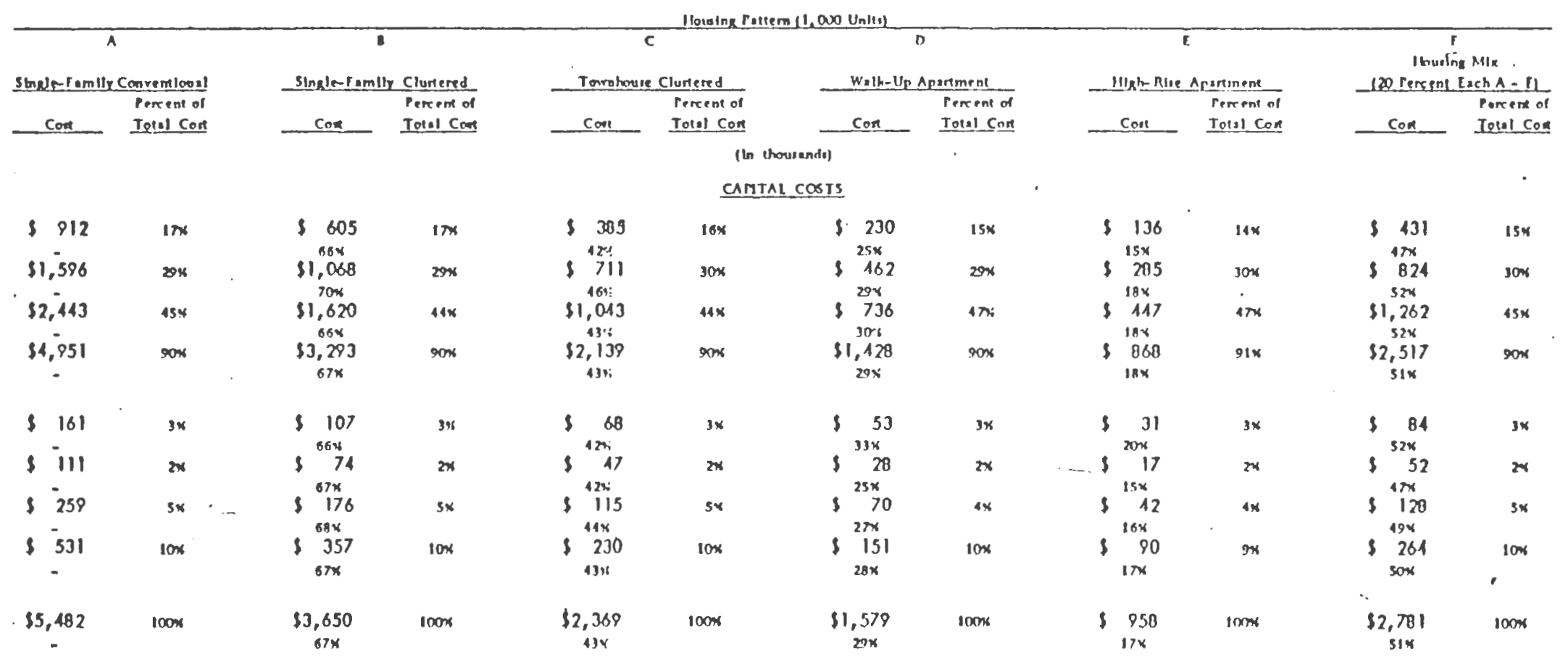

ORERTING AND MIAINTEMUNCE COSTS

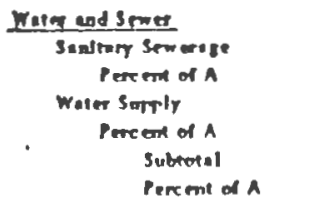

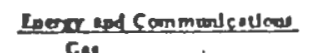

Cacent of A

Unetkit

Parcote of $\hat{A}$

Percent of $A$

Total Operothe and Malmersince

Percere of A

\begin{tabular}{|c|c|c|c|c|}
\hline$\$$ & -32 & $\pi x$ & $\underbrace{31}_{97 \times}$ & ox \\
\hline s & 32 & $7 x$ & ${ }_{100 x}^{32}$ & $\pi x$ \\
\hline$\$$ & -64 & $13 x$ & $\int_{\text {gax }}^{63}$ & $13 x$ \\
\hline 1 & 201 & 12x & $\left\{\begin{array}{c}201 \\
1000\end{array}\right.$ & $12 x$ \\
\hline$\$$ & 219 & $45 x$ & $\begin{array}{l}219 \\
1000 x\end{array}$ & $45 x$ \\
\hline$\$$ & $\begin{array}{l}420 \\
-\end{array}$ & ors & $\begin{array}{c}100 x \\
120\end{array}$ & $B \pi x$ \\
\hline$\$$ & & $100 x$ & $\underbrace{103}_{100 x}$ & $100 x$ \\
\hline
\end{tabular}

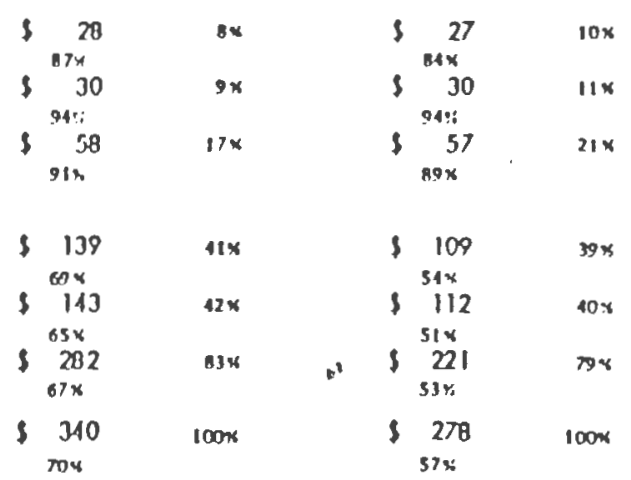

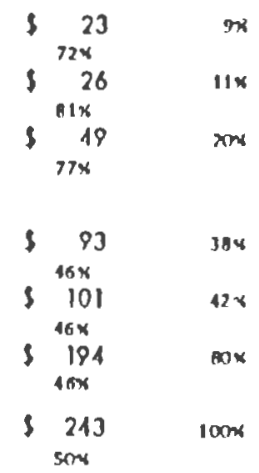

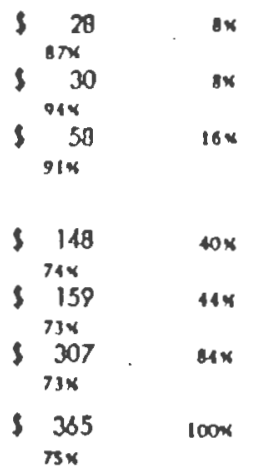

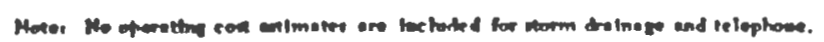

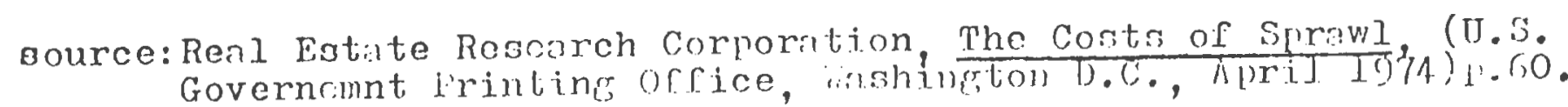




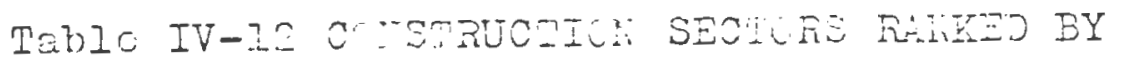
ETERGY ITIETSIMY

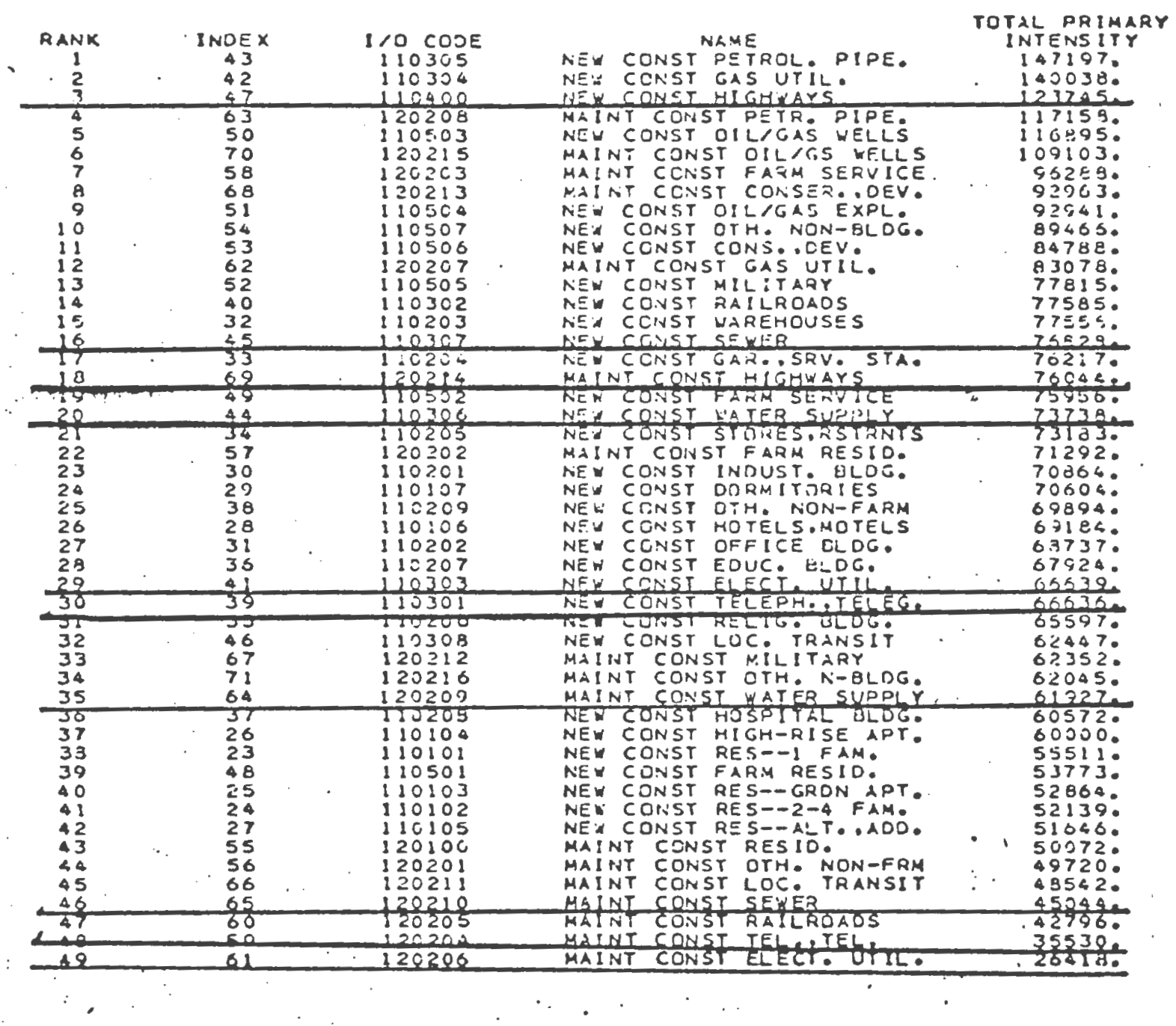

source:Hannon, $8 \epsilon 3 i$, Stein, Serber, Energy Use For Puilding Constmuction, (U_ ana-Champign, III.: Eners Reserch Grovp, Certer for Advinced Comptition, University of Illinois). Feb. 1977, p. 134. 
community infrastructure are among the most energy intensive. Of the forty-nine construction actirities listed, new highray construction, new sewer construction, new water supply construction. and highway maintenance are among the top twenty. New electrical and telephone utilities construction are ranked twenty-ninth and thirtieth respectively.

This information points to the energy savings available through reduction of length of infrastructure and transportation systems. In Davis, California the reduction of right of way widths was determined to be an energy saver, not only in terms of the material reduction, but also in terms of the reduction of asphalt surface available to collect and holit heat and also by increasing the capability of the using of trees to shade a larger percentage of road area from the sun.

\section{Street Lighting}

Streetlighting is another area where substantial energy savings can be attained. Although not primarily related to spatial considerations, streetlighting can provide considerable energy and cost savings through increasing lighting efficiencies. Upgrading traditional incandescent streetlighting systems to the use of mercury vapor luminaires or high pressure sodium luminaires can yield significant energy savings. High pressure sodium lighting is about 2.5 times as efficient as mercury vapor lighting and about 8.5 times efficient as incandescent lighting. In a case study conducted in a Massachusetts community under the auspices of the Department of Community Affairs it was found that the current streetlighting system could be upgraded to result in a 32 percent increase in illumination 
while obtaining a 28 percent decrease in power and 6.6 percent decrease in cost. ${ }^{18}$ Table IV-1j depicts the present and proposed street lighting system for Southbridge, Massachusetts.

In many communities there is substantial opportunities for energy savings in street lighting. It has been determined that in Massachusetts orer $3 j$ percent of the fixtures are of the obsolescent incandescent type. The process that has been recommended for making decisions about the upgrading of street lighting systems is as follows. 19

1. Establish a working committee to formulate recommendations regarding street lighting upgrades. It is suggested that the comittee include an official with budgetary responsibility for street lights, a representative of the policy department (becaluse of his familiarity with crime areas which require good lighting levels), representatives of the businesses and neighborhoods which may be affected, citizens with technical backgrounds, and a lighting expert from the utility.

2. Inventory the existing lighting system. Knowledge of the current installation is the baseline for making decisions about the improvements. The information required includes the number of each type of fixture installed, the location of the fixtures and the approximate spacing. Also obtain the rate the utility is charging for the current system. The utility can provide this information.

3. Find out what alternatives are available from the utility. Obtain information on the cost and availability of more efficient lighting alternatives. obtain information on standards and guidelines for spacing, pole heights, and light intensity which are recommended by the utility (Appendix D).

4. Identify specific opportunities for lighting upgrades by examining each installation in the inventory. Remember the importance of matching the lighting to the task. The intensity of light from high pressure sodium is not always appropriate to certain uses, such as in residential areas. Development density is important when upgrading to higher intensity lighting because the area which one fixture is capable of lighting is much greater, therefore it is more appropriate to higher density developments. Caution 
Table IV-13

\author{
SOUTHBRIDGE \\ MUNICIPAL STREET LIGHTING SYSTEM
}

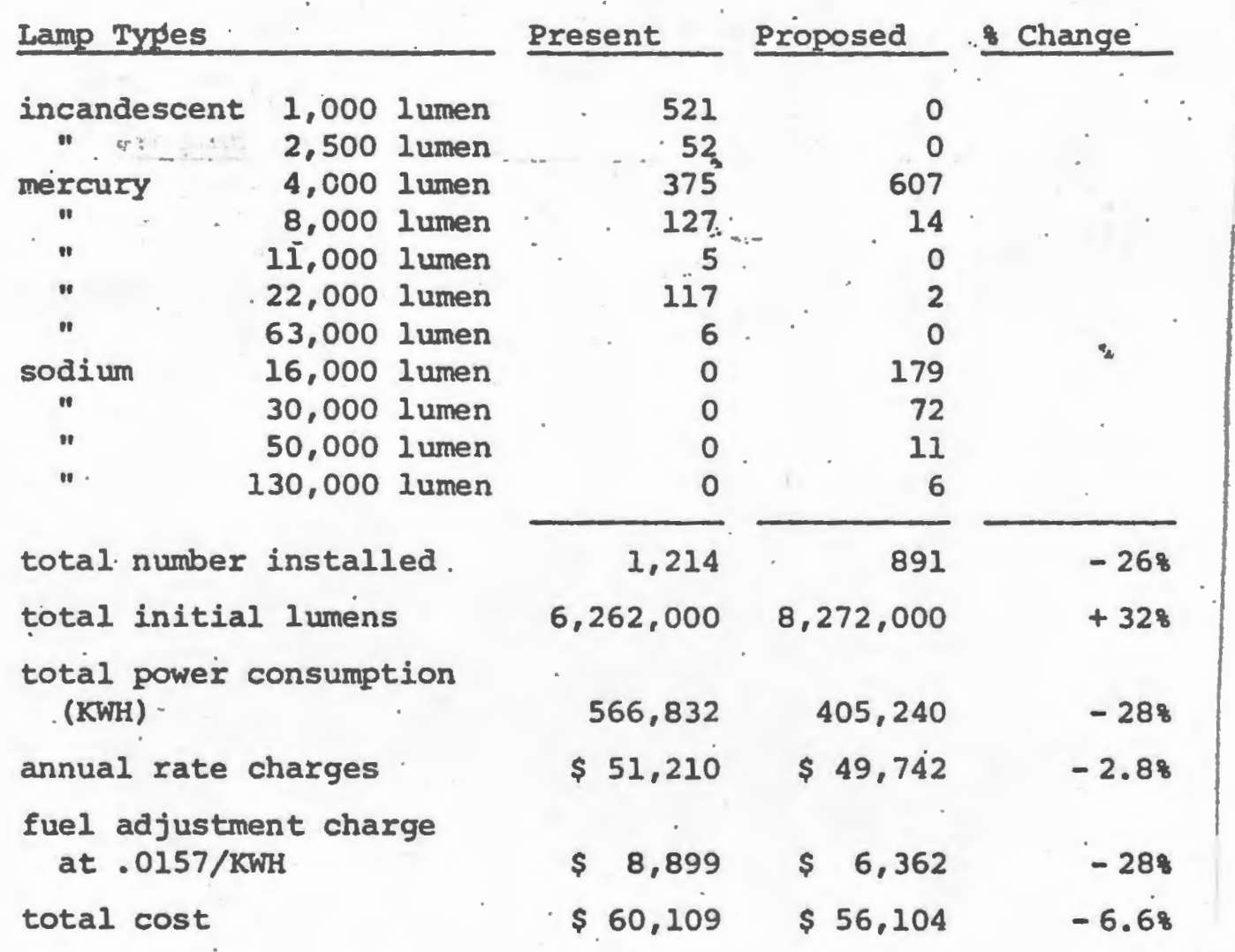

\footnotetext{
source: Massachusetts Department of Community Affairs, "Energy Management in Irunicipal Street Lighting",(March 1977.) p.23.
} 
Table IV-14

COMPARISONS OF COMMONLY USED

STREET LIGHTING LAMPS

\begin{tabular}{|c|c|c|c|c|c|c|c|c|c|c|c|}
\hline Lamp Type & $\begin{array}{l}\text { Watts } \\
{[a]}\end{array}$ & & $\begin{array}{l}\text { Rated } \\
\text { Initial } \\
\text { Lumens } \\
\text { [a] } \\
\end{array}$ & $\begin{array}{l}\text { Maintained } \\
\text { Lumens at } \\
\text { End of } \\
\text { Relamping } \\
\text { Period }\end{array}$ & $\begin{array}{l}\text { Lumens } \\
\text { Per. } \\
\text { Watt } \\
\text { (Ratio) } \\
\end{array}$ & $\begin{array}{l}\text { Average } \\
\text { Utility } \\
\text { Rate (1976) } \\
{[b, c]}\end{array}$ & $\begin{array}{l}\text { Economy } \\
\text { Dollars } \\
1000 \text { Lu } \\
{[\mathrm{b}, \mathrm{c}]}\end{array}$ & $\begin{array}{l}\text { in } \\
\text { Per } \\
\text { imens }\end{array}$ & $\begin{array}{l}\text { Typical } \\
\text { Mount } \\
\text { Helght }\end{array}$ & & $\begin{array}{l}\text { Average } \\
\text { Footcandles } \\
\text { Illumination } \\
\text { Over Area } \\
6000 \text { sq. Et. }\end{array}$ \\
\hline Incandescent & & 103 & 1,200 & 960 & 10.7 & $\$ 34.29$ & $\$$ & 31.17 & & $25^{\circ}$ & negligible \\
\hline Incandescent & & 202 & 2,900 & 2,320 & 12.6 & 56.87 & & 22.30 & & $25^{\prime}$ & negligible \\
\hline Incandescent & & 327 & 4,850 & 4,025 & 12.3 & 70.14 & & 17.43 & & $25^{\circ}$ & .27 \\
\hline Mercury & & 100 & $4,000\{d\}$ & 1,952 [d] & 31.6 & 48.59 & & 15.38 & & $30^{\prime}$ & .21 \\
\hline Mersury & & 175 & $8,150\{a\}$ & $4,824 \quad[d]$ & 40.1 & 64.22 & & 9.16 & & $30^{\prime}$ & .45 \\
\hline Sodium & & 70 & 5,800 & 3,387 & 74.6 & $\mathrm{n} / \mathrm{a} \quad[\mathrm{e}]$ & $n / a \quad e]$ & & & $30^{\prime}$ & .50 \\
\hline Sodium & & 100 & 9,500 & 5,548 & 85.5 & $\mathrm{n} / \mathrm{a} \backslash \mathrm{e}\rfloor$ & $n / a \quad[e]$ & & & $30^{\circ}$ & .81 \\
\hline Sodium & & 150 & 16.000 & 9,344 & 90 & $\mathrm{n} / \mathrm{a}\{\mathrm{e}\}$ & $n / a \quad[e]$ & & & $35^{\prime}$ & 1.08 \\
\hline Sodium & & 250 & 30,000 & 17,520 & 92.8 & 123.84 & & 5.34 & & $35^{\circ}$ & 1.86 \\
\hline Sodi um & & 400 & 50,000 & 29,200 & 112.5 & 176.95 & & $3.9,3$ & & $40^{\circ}$ & 3.32 \\
\hline
\end{tabular}

a wattage and lumen data were taken from lamps manufactured by General electric

b includes fuel charges

C utility rates for this table were derived from the rate schedules of the following companies: Boston Edison, Mass Electric, Western Mass. Electric, Fall River Electric Light

d horizontal burning position

e although lighting companies produce these lamps, they are not widely enough available on utility rate schedules to draw conclusions as to costs

source:lilass: chusetts Depurtment of Community Affairs, "Inergy hanarement in liunicipal Street Lighting", (March 1977), p. 35 . 
should also be taken with regard to conversion to high intensity lighting because the possible need for higher poles may make the economics undesirable.

SITE PLANNING AND BUILDING DESIGN

Structures consume a great deal of energy in keeping their internal environment in a steady state (within a temperature and relative humidity comfort range). Energy is consumed in keeping a structure in the steady state because there exists a situation of disequilibrium between the internal environment and the external environment. The amount of energy needed to keep a structure in the steady state depends upon the stress put on it by the external environment. This external environment of a structure can be diminished by minimizing the conflict between the external environment and the internal environment. This conflict can be minimized by decreasing a building's vulnerability to environmental stress and by increasing its capability for utilizing energy which is available natural1y in the external enviromment.

\section{Climate}

The amount of energy available in the environment is dependent upon global conditions and local conditions. Globally, sun angle varies with latitude and season of the year. The most energy is available to the earth when the sun angle is closest to 90 degrees, perpendicular to the earth. This only happens in the tropics, between 23 degrees north latitude and 23 degrees south latitude. In higher latitudes the sun angle is always less than 90 degrees and less energy is available. In Providence, 42 degrees north latitude, the maximum sun angle during 
the year is about 70 degrees. This occurs on the summer solstice, June 22, of each year. The minimum sun angle in Providence occurs on the winter solstice, December 22 , and is about 25 degrees. This means that only about forty-three percent of the energy available on June 22 is available on December 22. The range of stress which this example portrays is as important a factor in building energy useage as the magnitude of stress. This means that the desired steady state condition of $68^{\circ} \mathrm{F}$ will have to be maintained under external conditions ranging from $-5^{\circ} \mathrm{F}$ to $100^{\circ} \mathrm{F}$ annually. The sun also creates wind currents and ocean currents which prevail over certain sections of the globe. Local conditions serve to modify global climate and create unique climatic conditions which are specific to an area. Natural features and man made aspects of the landscape are both factors in the nature of the local climate. Breezes occur near water bodies and in mountain valleys due to the creation of convection currents as a result of different temperatures in proximate areas. Sea breezes ${ }^{20}$ occur because of the difference in specific heat of water and earth. Water heats up more slowly than earth and retains heat longer. As a result, the heat over the earth during the day time rises and is replaced by the cooler ocean air. At night, the land quickly loses its heat and becomes relatively cooler than the adjacent water body thus creating a wind in the reverse direction. Sea breezes will commonly penetrate from fifteen to fifty miles inland in the middle latitudes and are prominant in the summer.

The same effect occurs in cities. ${ }^{21}$ This is called the urban heat island effect. Concrete, asphalt and other building 
materials which predominate in the city tend to heat up quick1y and hold more heat than the surrounding countryside, thus setting the conditions for the creation of convection currents. Other conditions in the city also effect climate. Pollutants in the atmosphere tend to cause increased rainfall and also serve to create a greenhouse condition which serves to hold heat in the city from radiating into the atmosphere. Wind currents are also created in the city due to large buildings which tend to channel winds and increase their momentum.

Mountain and valley winds 22 are common local occurances which, like sea breezes, may modify the prevailing wind pattern. The thermal up slope wind is created perpendicular to the valley (up and down the slopes). The southern slopes of mountains in the valleys with an east west axis are most effected in the northern hemisphere because of the intense solar radiation received. Imbalances between the temperature of the valley floor and the heated slope cause convection currents which create winds based on the same principle as land/sea breezes. This principle also applies to mountains with a north-south axis. In the early morning east facing slopes will receive the greatest insolation after noon winds develop accordingly. Valley winds are winds that follow the valley axis and are again based on convection currents. As the valley floor heats up the hot air rises up the valley. At night the cold air drains back down into the valley.

These local climatic effects occur diurnally and are predominant in the summer months in the middle latitudes. The summer predominance and diurnal nature are logical because 
these local climate conditions are dependent upon intense insolation to create convection currents. In mountains, at night when the temperature is cool, cold air will drain down to the valley floor making the effects even more extreme than in the case of urban breezes and sea breezes.

The two most important conditions to have information on with regard to climate are wind and insolation. Understanding the dirunal and annual ynamics of these conditions are important when attempting to reduce energy use through site and building design. Local climate interacts with global climate. Diurnal cycles interact with annual cycles. Energy efficient design can be best achieved with site specific data. Data a avilable through local weather stations at colleges, television stations, radio stations, and the U.S. Weather Bureau will be the second best alternative to site specific data. Plotting wind information on a wind rose Figure IV-4 will reveal the net affect of winds in the area. Specific information about the direction and velocity of winds on a seasonal or monthly basis is particularly important to good site design. Awareness of topography and surrounding geography is a prerequisite to understanding local climate and making it a consideration in site planning and building design.

\section{Building Design Considerations}

The amount of energy that can be saved by incorporating energy efficiency into building design is considerable. Some estimates maintain that new buildings explicitly designed to be energy efficient could save as much as eighty percent of the fuel they would consume at present levels. The American In- 
Figure IV-4 WIND ROSE FOR SUMMER AND WINTER NORTHEAST LOCATION

(percent of seasonal winds from each compris direction)
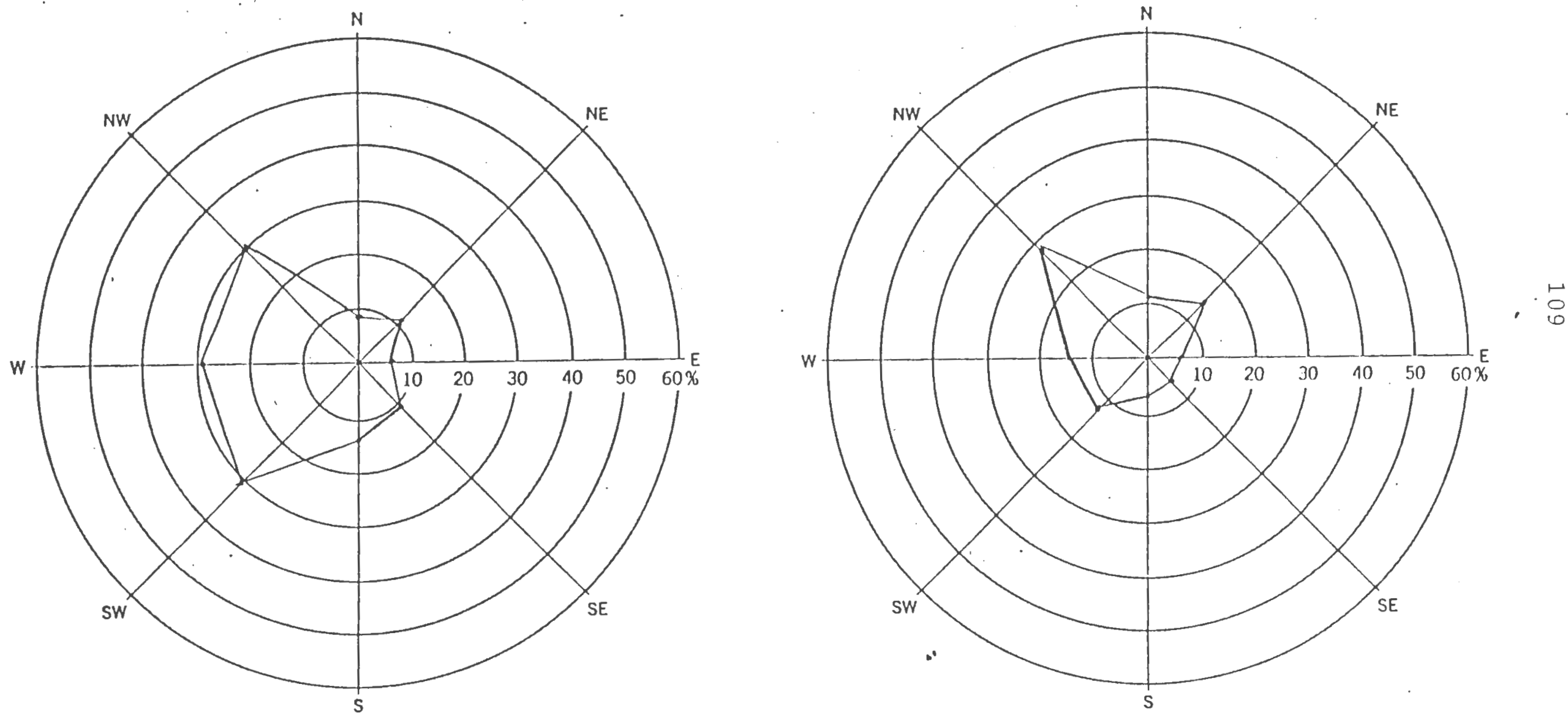
stitute of Architects has determined that with thirty percent energy savings for existing buildings and sixty percent savings for new structures the U.S. would save 12.5 million barrels of oil a day by 1990.23 In Chapter III, energy savings through the selection of and performance of building materials was discussed. In this chapter, energy savings through design performance is discussed. This section will focus on the residential sector but, the same principles can be applied to other building types. 24 when building energy efficient housing there are two general guiding principles that should be followed. They are:

1. Minimize vulnerability to unwanted aspects of the environment.

2. Maximize capability to utilize energy naturally available in the environment.

Both of these principles can be attained through proper site selection, orientation of the building on the site, landscaping, structural design, and materials selection. These points will be addressed briefly relative to locations in the northeast.

Minimizing vulnerability to unwanted aspects of the environment will involve selection of a site that is not a collection basin for cold air drainage in the winter and provides breezes in the summer. If a site is selected that is exposed to unwanted winter winds, for example, it can be sheltered from these winds through the use of coniferous shrubbery and trees as barriers to divert and diffuse the wind. Conversely, elements of the landscape which serve to trap unwanted cold air or divert cooling summer breezes should be avoided or removed. This includes removal of trees which may be blocking desirable winter heat gain in the southern face of housing. Figures IV-5 
$\because$ cerces walls or vegetation can block natumal air flow patienns. care must de TAKEN DURING SITE DESIGN to PROVIDE THE NFCESSARY VISUAL CONTROL WHILE AVOIDING adverse clumatic conoitions. as coolea AIR ILOWS DOWNHIILL IN THE EVENING.

FENCES, WALLS OR PLANIINGS SHOULO NOT UNINIENTIONALLY DAM TIIIS FLOW AND THUS CREATE A COLD AIN POCKET WIIERE IT IS NOT WANTED.

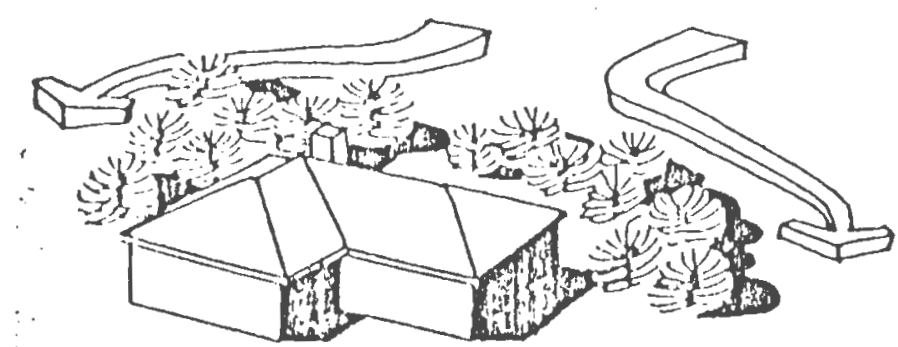

VEGETAIION PROPERLY PLACED CAN DEFLECT RATHEN THAN DAM COLD AIR FLOW

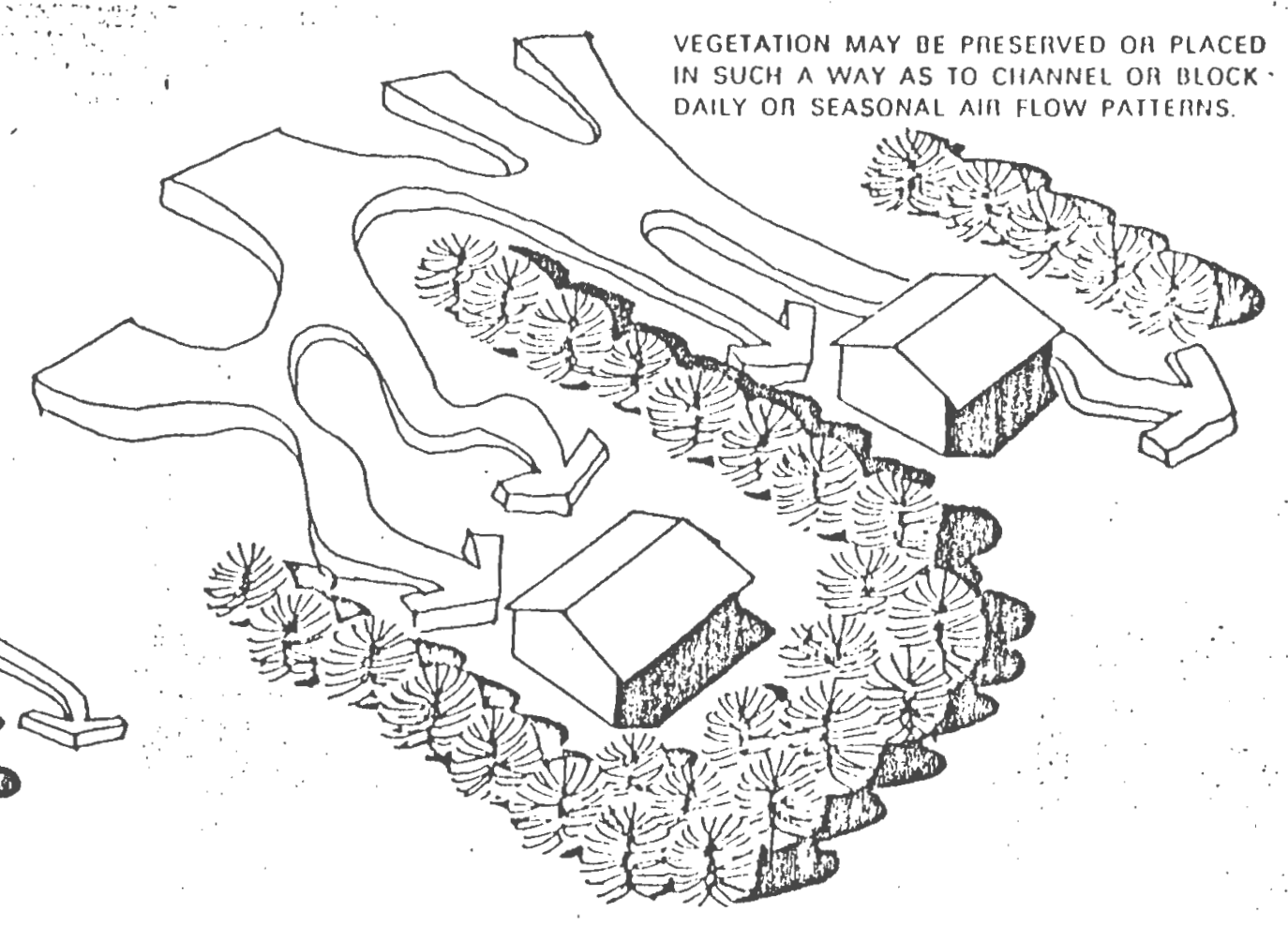

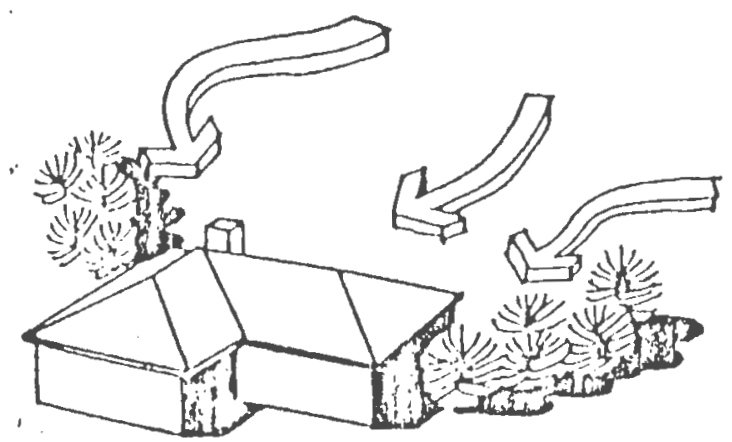

OWELLING UNPAOTECTED FROM COLD AIR riflow

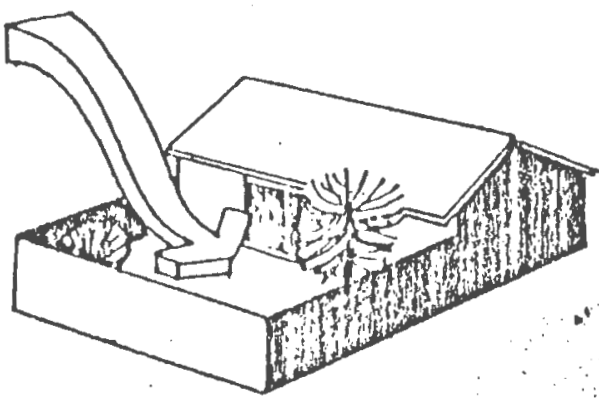

COLD AIR TRAPPED BY FENCE

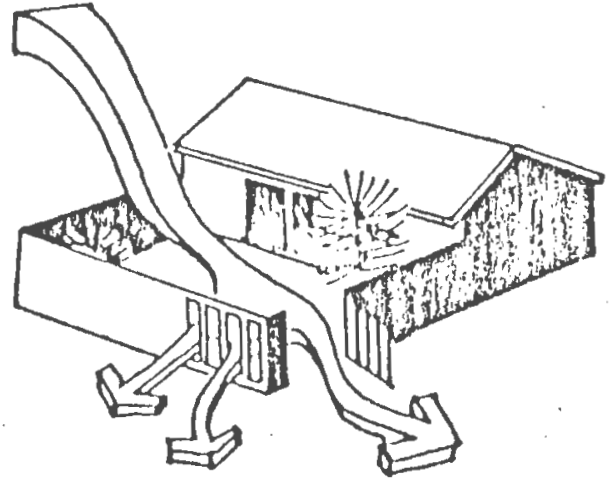

FENCE DESIGN CAN PROVIDE FOR COLD AIR DRAINAGE 
Pigure TV-6

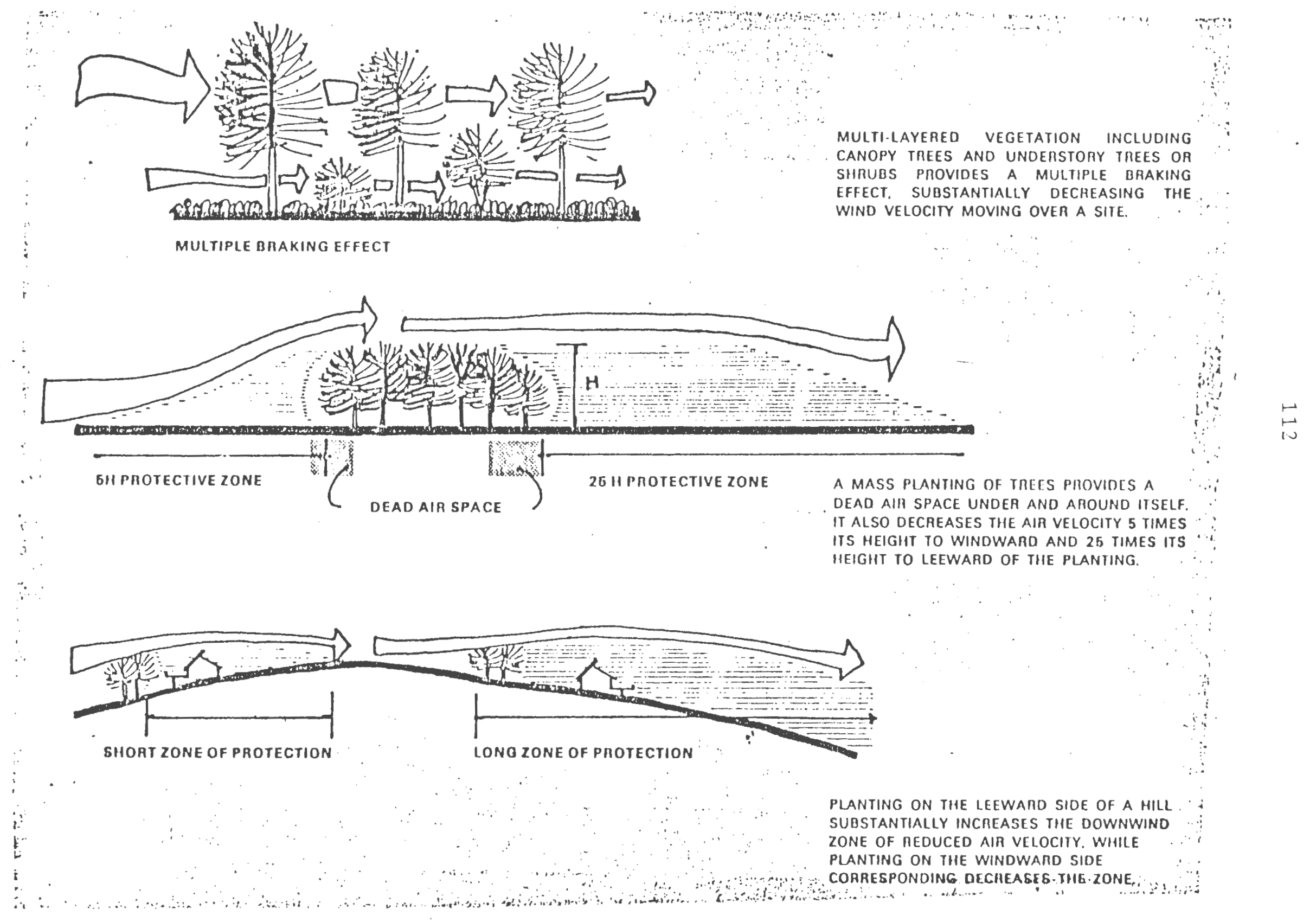


and IV-6 depict some points of hor landscaping can be used in energy efficient design.

Minimizing a structure's vulnerability to the environment also involves some principles of building design and building material performance. In the middle latitudes structures can minimize their vulnerability by decreasing heat loss in the winter and decreasing heat gain in the summer. Winter heat loss can be minimized by reducing susceptibility to winds, which are a factor in heat loss, as described above and by increasing the $R$ value of the wall composition. As discussed in Chapter II, this can be achieved by using materials with good resistance to heat flows and minimizing the use of building materials that do not. Minimizing glass area on the vulnerable north side of structures is a good way to decrease heat loss. Figure IV-7 illustrates how building overhang can be designed to provide for minimal summer heat gain by shading while providing unimpeded insolation during the heating season.

Ralph Knowles, in his book Energy and Form, hypotesizes that the vulnerability of structures to the external environment can bedescribed as a function of the ratio between exposed surface and contained volume. 25 surface to volume ration (S/V) is referred to by knowles as the coefficient of susceptibility. Higher stress environments require lower coefficients of susceptibility, while lower stress environments require higher coefficients of susceptibility. Tro attributes of form that effect the coefficient of susceptibility are size and shape.

Figure IV-8 depicts the correlation between size and shape and surface to volume ration. Figure $I^{r}-8$ a depicts an expand- 


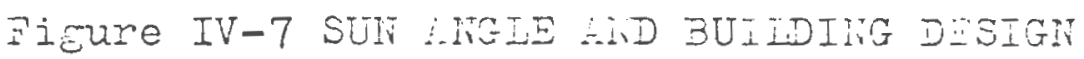

\section{Sun Angles}

Bearing (or azimuth) angle ( $\beta$ ) and altitude angle ( $\alpha$ ) of the sun are given in solar tables." These sun angles, along with the angle of orientiation relative to the north-south axis, can be used to predict shadows for a particular time at a specific latitude. The depth of shade $(d)$ in feet can be found by $d=x($ ran $\alpha / \cos \beta)$ where $x$ is the overhang width in feet. Basic sun angle geometry is given below.

-Sce: pp. 388-92. ASHRAE Handbook of Fundamentais (1972).

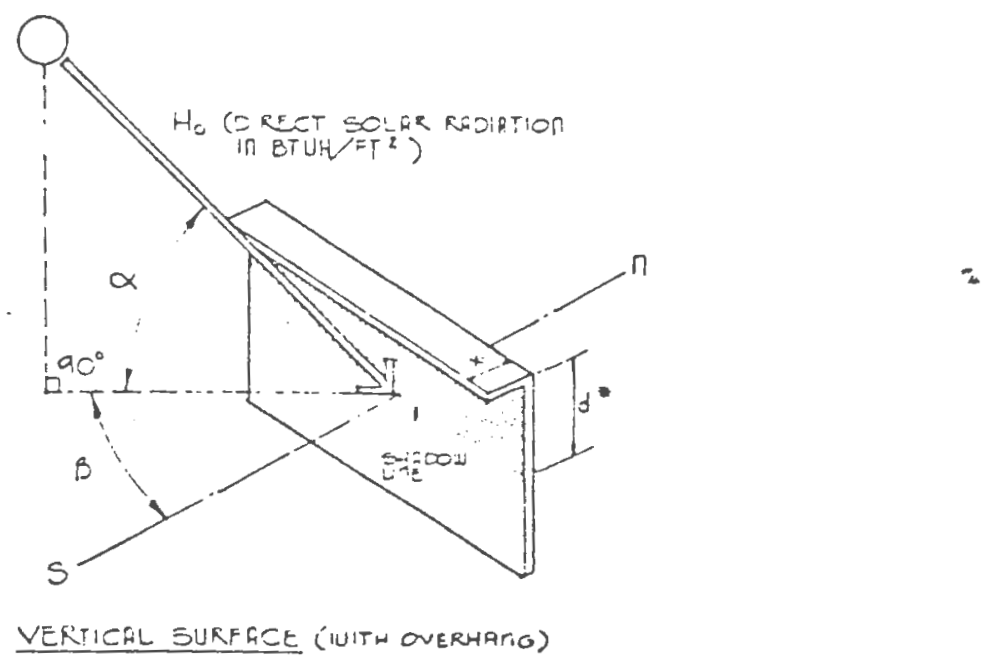

\section{Solar Orbit (at $40^{\circ}$ North Latitude)}

The sun's movement across the sky differs in bearing and altitude angles with the seasons. Exaggerated orbits for summer and winter conditions at $40^{\circ}$ north latitude are shown below. Note that seasonal variations also alter the solar radiation values.
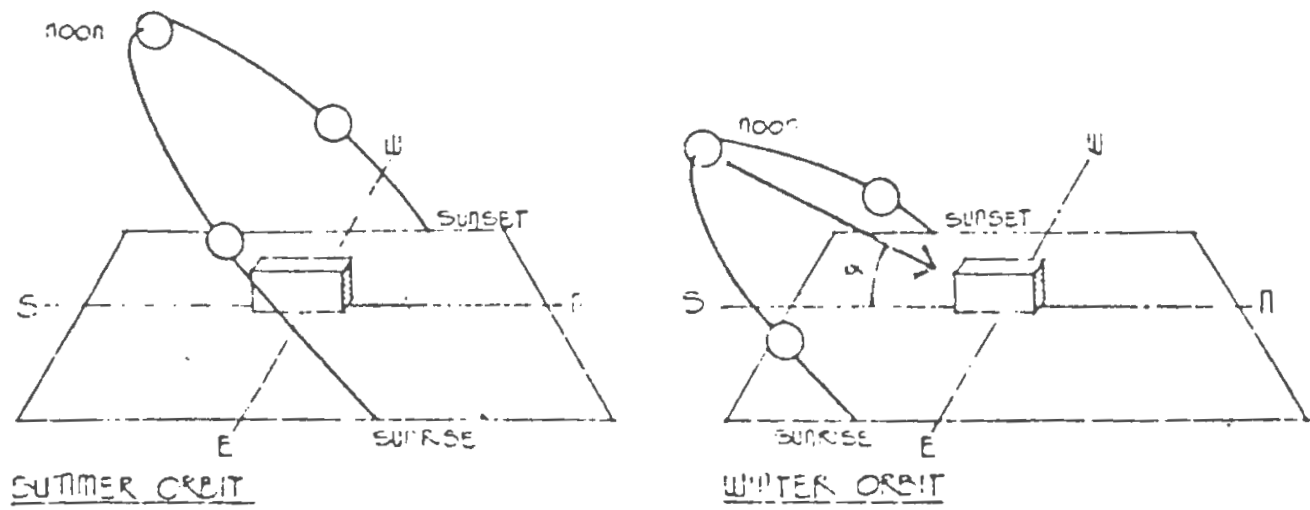

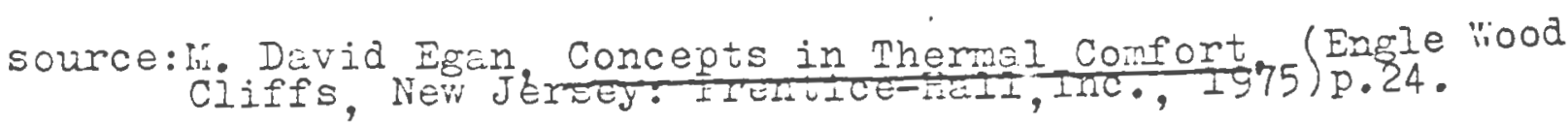



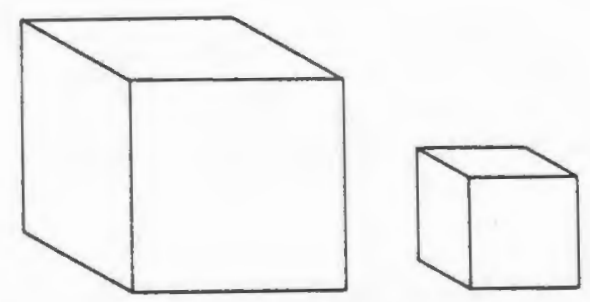

Doubling the dimensions of a cube decreases its surface-to-volume ratio by one half.

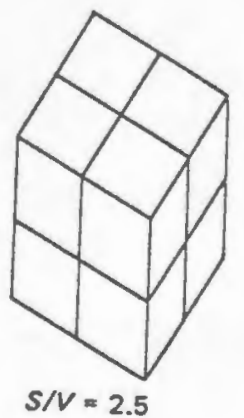

Figure IV-8b Shape

FigureIV-8a

Size

$s / v=2.5$ Figure IV-8 SUREACE TO VOLUUi.E(S/T)
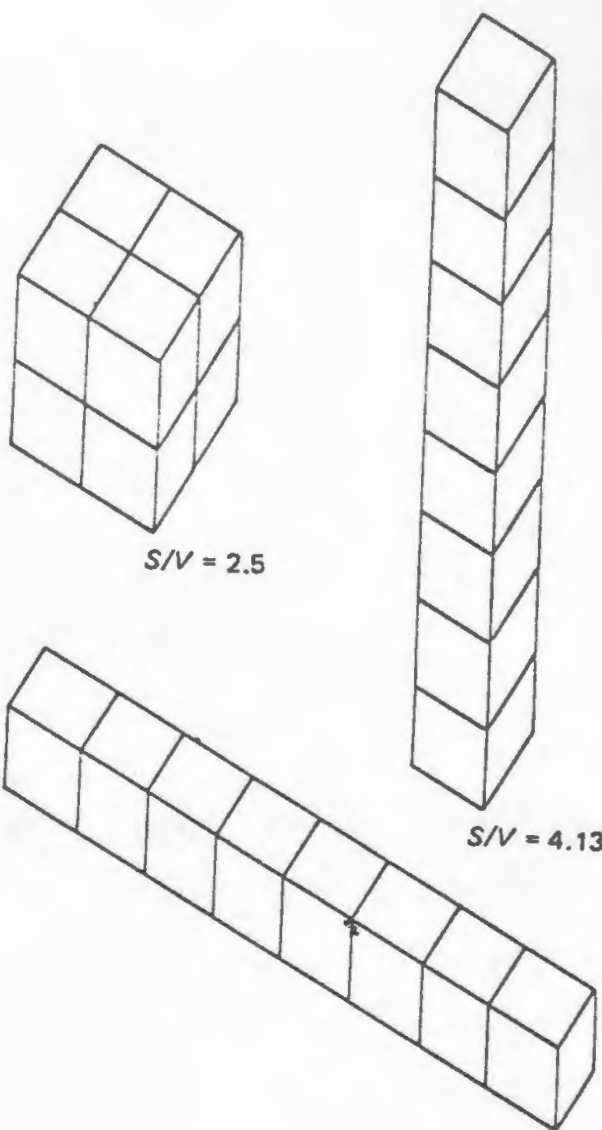

$S / V=3.25$

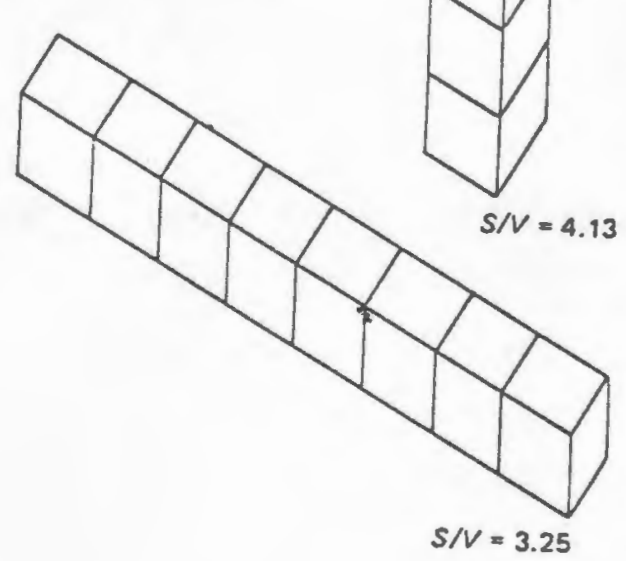

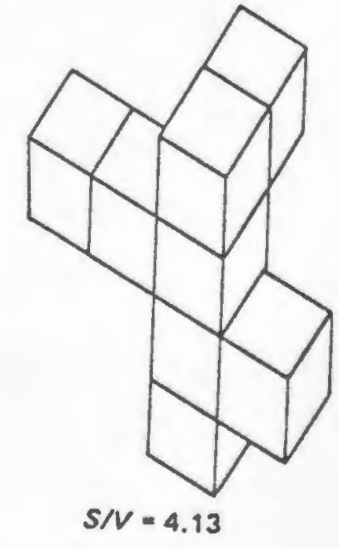

The shape of the form has on effect on its surface-to volume ratio.

Simple shapes generally have a lower surface-tovolume ratio than complex shapes of the same volume.

source: Ralph Enowles, Energy and Form, (Cambridge: liIT Press, 1974) 
ing cube. A unit cube in contact with the ground on one of its faces exposes five unit surfaces while its volume is one, therefore $S / Y=5$. If the edge diminsions of that cube are doubled its surfaces total 20 while volume is eight, therefore $S / T=2.5$, or half of the smaller cube. The small cube then is more vulnerable simply because smaller things have higher surface to rolume ratios. $S / Y$ is to a lesser extent a function of shape and can be illustrated by comparing the same volume in different configurations. Figure IV-Sb takes the larger of the two cubes and rearranges the volume into a stack of eight equal cubes and a row of eight equal cubes. The results are depicted. Estimates of energy consumed in various types of housing in the Baltimore/Washington area that are illustrated in Table IV-I5 show some agreement with this theory. Energy consumption per $f t^{2}$ and per person is shown to decline in the larger structures. Maximizing capability to utilize energy naturally available in the environment will involve selection of a site that has access to the sun during the heating season. A site that also has access to seasonal breezes during the cooling season is most desirable. Proper orientation of the structure on the site to take advantage of available solar insolation is essential. The long axis of a structure should run east to west to take full adrantage of available sunlight. In this way the maximum area of the house is available to collect solar insolation. The average solar insolation outside of the earth's atmosphere when the sun's rays are perpendicular is equal to $428 \mathrm{BTU} / \mathrm{s} / \mathrm{hr} / \mathrm{ft} \mathrm{t}^{2}$. At $42^{\circ}$ north latitude this figure ranges from 398 to 171 BTU's/hr/ft ${ }^{2}$ depending on the season. CIoud 
Table IV-15 COMPARISON OF ESTIMATED ENERGY CONSUMP'TION VALUES FOR CHARACTERISTIC SINGLE-FANILY AND MULTI-FAMULY DWELLINGS

\begin{tabular}{|c|c|c|c|c|c|}
\hline $\begin{array}{l}\text { Type of Dwelling } \\
\text { Unit }\end{array}$ & $\begin{array}{l}\text { Area } \\
\mathrm{Ft}^{2}\end{array}$ & $\begin{array}{l}\text { Persons } \\
\text { Per Unit }\end{array}$ & $\frac{\text { Total Energ }}{\text { Per Unit }}$ & $\begin{array}{c}\text { Consumption, } \\
\text { Per Person }\end{array}$ & $\frac{\text { Therms/ripar }}{\text { Per } \mathrm{Ft}^{2}}$ \\
\hline $\begin{array}{l}\text { Balanced Home, } \\
4 \text { bedroom } \\
\text { (Ref. 20) }\end{array}$ & 1500 & 4 & $28 B 6$ & 721 & 1.92 \\
\hline $\begin{array}{l}\text { Town House } \\
3 \text { bedroom }\end{array}$ & 1300 & 4 & 2363 & 566 & 1.75 \\
\hline $\begin{array}{l}\text { Low Rise } \\
2 \text { bedroom } \\
\text { apartment }\end{array}$ & 1140 & 3 & 1724 & 575 & 1.51 \\
\hline $\begin{array}{l}\text { lligh Rise } \\
1 \text { bedroom } \\
\text { apartment }\end{array}$ & 850 & 2 & 1323 & 662 & $\begin{array}{l}1.56 \\
\vdots\end{array}$ \\
\hline $\begin{array}{l}\text { ligh lise } \\
2 \text { bedroom }\end{array}$ & 950 & 3 & 1482 & 494 & 1.57 \\
\hline
\end{tabular}

iljartment

dis gas consumed in unit plus therms used to generate electric power consumed in unit

source:Hittmin issoci: los, Incorportted, "Residentint Finersy

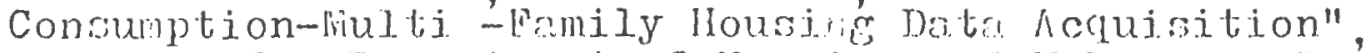
prepred for Depirtment of IJousing and Urbun Jevelopment, october $1972, \mathrm{p} .55$. 
cover, pollution, and other atmospheric conditions further reduce this figure. However, Table IV-16 shows insolation which is available at approximately $42^{\circ}$ north latitude, in Boston. As this table depicts, a verticle glazing ( $90^{\circ}$ slope) facing due south (azimuth 0 ) would receive larger shares of insolation in the heating season, months with mean temperatures below $65^{\circ} \mathrm{F}$, than in the three sumer months. A large south facing window would capture this energy for use in colder months, while an appropriately designed overhang would shade the window from unwanted rays in the heating months. Use of rock, concrete, or other media in the floor of construction or some other aspect of house design will absorb and store excess heat thất may be gained during times of the day when insolation is too intense to be totally consumed in heating the structure. When using flat plate collectors to receive insolation Table IV-16 indicates that approximately a 50 degree tilt (slope) of the panel is most desirable, at this latitude.

This section on site planning and building design presented some very fundamental concepts. Specific building designs can incorporate numerous passive and active solar design features. ${ }^{26}$ The economics of active solar systems have not been established as being cost competitive with conventional fuel sources as of 1979 prices. As prices of fuel go up and costs of solar systems go down, with improved technology, solar likely will become competitive with conventional energy sources. Currently, solar is already competitive with electricity for use in heating domestic hot water. Orienting new structures to take advantage of energy available through passive means will also 
Table IV-16 INSULATION AND WEATHER DATA FOR BUSTON

\begin{tabular}{|c|c|c|c|c|c|c|c|c|c|c|c|c|c|c|}
\hline \multicolumn{2}{|c|}{ BOSTON } & JAN & $\begin{array}{l}42.22 \\
\text { FEB }\end{array}$ & MAR & APR & MAY & JUN & JUL & AUO & SEP & OCT & Nov & OEC & \\
\hline \multirow{3}{*}{\multicolumn{2}{|c|}{$\begin{array}{l}\text { PTOT ZOWTAL RAO. } \\
\text { AVE. TEMP. } \\
\text { OCOREE-DAYS }\end{array}$}} & जा & 729 & 1078 & 1340 & 7738 & TB37 & Te2G & -1565 & 1255 & $-87 \sigma^{-1}$ & 535 & 438 & TВTUIDAY =FT2) \\
\hline & & 30.2 & 30.2 & 35.6 & 46.4 & $57.2^{\circ}$ & 60.2 & 71.0 & 69.0 & 62.6 & 33.6 & $42 . \theta$ & 32.0 & (F) \\
\hline & & 1000 & 972. & 846 & 513. & 200 & 36. & 0 & 9 & 60. & JiG. & 600. & 983. & (F-DAYS) \\
\hline & & & AVERKUE & E DATL & RADTA & TOH ON & TILTEO & SURA ACE & S-TETO & $70 A Y=F$ & & & & \\
\hline SLOPE & AZIMUTH & JAN & FEB & MAR & APR & HAY & JUN & JUL & AUO & SEP & OCT & Nov & OEC & \\
\hline 20 & 0 & 740 & 944 & 1202 & 1418 & 1730 & 1778 & 1709 & 1016 & 1410 & 1106 & 740 & 651 & \\
\hline 30 & 0 & 8307 & 7025 & 7310 & 7414 & 7677 & 7701 & 7722 & 7595 & $1449^{-}$ & 7184 & 8187 & $736^{-}$ & \\
\hline 40 & o & 900 & 1074 & 1303 & 1079 & 1592 & 1595 & 1623 & 1536 & 1450 & 1234 & 070 & 003 & \\
\hline 30 & 0 & 947 & 1101 & 1322 & 1016 & 1477 & 1461 & 1494 & 1448 & 1417 & 1254 & 916 & B50 & \\
\hline 60 & 0 & 970 & 1101 & 1201 & 1226 & 1035 & 1303 & 1340 & $\mid 301$ & 1352 & 1244 & 901 & 875 & \\
\hline 70 & 0 & $969-$ & 7075 & 7211 & Titz & 7172 & 7728 & 7756 & 730 & $7250^{-}$ & 1205 & 923 & 079 & \\
\hline 80 & 0 & 943 & 1024 & 1114 & 978 & 993 & 943 & 979 & 1028 & 1136 & 1130 & 093 & $0 \in 0$ & \\
\hline 90 & 0 & 895 & 950 & 990 & 831 & 810 & 759 & 791 & 057 & 993 & 1044 & 042 & 820 & \\
\hline 20 & -19 & 732 & -930 & -1250 & $-1 \times 17$ & -732 & 1701 & 1792 & $761 \sigma^{\circ}$ & 1412 & 1097 & $7 \mathrm{J2}$ & $64 J^{-}$ & \\
\hline so & 15 & $81 \theta$ & 1009 & 1304 & 1414 & 1081 & 1707 & 1727 & 1395 & 1445 & 1171 & 807 & 724 & - \\
\hline 40 & 19 & 804 & $103 \theta$ & 1322 & 1002 & 1600 & 1604 & 1632 & 15.1 & 1.445 & 1217 & $B G J$ & 700 & \\
\hline 50 & 15 & 928 & 1082 & 1310 & 1022 & 1489 & 1475 & 1507 & 1457 & 1414 & 1204 & 090 & 8ว2 & \\
\hline$-60^{-}$ & $75-$ & 949 & -1000 & -1209 & -1236 & -1352 & ᄀง 22 & 1350 & -1340 & 7352 & -1222 & $911^{-}$ & 056 & \\
\hline 70 & 13 & 940 & 1052 & 1199 & 1127 & 1194 & 1152 & 1190 & 1210 & 1260 & 1100 & 902 & 057 & \\
\hline 00 & 13 & 919 & 1000 & 1103 & 990 & 1021 & 971 & 1000 & 1054 & $11+2$ & 1111 & 071 & 837 & \\
\hline 90 & 15 & $\theta 70$ & 923 & 907 & $B 50$ & 81.4 & 792 & 026 & 809 & 1005 & 1017 & 020 & 791 & \\
\hline 20 & jo & 707 & 913 & 1238 & 1411 & 1735 & 1780 & 1790 & 1014 & 1397 & 1073 & 709 & 620 & \\
\hline Jo & 30 & 781 & 975 & 1200 & 1410 & 1692 & 1720 & 1742 & 1597 & 1927 & 1137 & 774 & C91 & \\
\hline 40 & 30 & 837 & 1016 & 1295 & 1302 & 1621 & 1631 & 1057 & 1551 & 1.127 & 1175 & 021 & 745 & \\
\hline-50 & 30 & 072 & - & -1202 & - & -1522 & -1514 & 1545 & 7476 & -1090 & ר וסE- & 040 & 781 & \\
\hline 60 & 30 & 806 & 1026 & 1242 & 1249 & 1098 & 1375 & 1410 & 1376 & 1039 & 1170 & 054 & 797 & \\
\hline 70 & Jo & 877 & 994 & 1175 & 1149 & 1255 & 1219 & 1257 & 1253 & 1254 & 1127 & 041 & 794 & \\
\hline 80 & jo & 847 & 941 & 1084 & 1001 & 1097 & 1052 & 1090 & 1112 & 1145 & 1058 & 807 & 771 & \\
\hline $90^{-}$ & 30 & 798 & 067 & -975 & $90 J$ & .935 & 805 & 922 & 962 & - & 900 & 755 & 730 & \\
\hline 20 & 45 & 669 & $87 C$ & 1209 & 1399 & 1736 & 1797 & 1003 & 1000 & 1072 & 1006 & 676 & 505 & \\
\hline jo & 45 & 728 & 928 & 1242 & 1096 & 1700 & 1743 & 1750 & $\begin{array}{r}1591 \\
-1\end{array}$ & 1395 & 1007 & 726 & 640 & \\
\hline$-40^{\circ}$ & -45 & 769 & 950 & -1252 & 7378 & 7639 & TGGA & 1084 & $-15 \mathrm{~s}$ & -1393 & 7116 & $781^{-}$ & $600^{\circ}$ & \\
\hline 50 & 45 & 793 & 967 & 1257 & 1022 & 1553 & 1563 & 1500 & 1485 & 1365 & 1120 & 779 & 705 & \\
\hline 60 & 45 & 798 & 955 & 1198 & 1231 & 1444 & 1441 & 1470 & 1096 & 1311 & 1101 & 770 & & \\
\hline 70 & 43 & 784 & 922 & 1135 & 1101 & 1017 & 1002 & 1033 & $\begin{array}{r}1206 \\
\end{array}$ & 1233 & 1057 & 760 & 703 & \\
\hline $80^{-}$ & 49 & 752 & $870^{\circ}$ & -1051 & -1054 & -1175 & 1152 & 1104 & -1159 & 73 & -992 & 725 & 077 & \\
\hline 90 & 45 & 704 & 002 & 952 & 937 & 1020 & 1000 & 1031 & 1024 & 1019 & 910 & 675 & EJG & \\
\hline
\end{tabular}

source:U.S. Depittment of Energy, Introduction to Solir lle ting, Cooling, Desien, arud uizing, $1977, \mathrm{p} .2-26$. 
enable structures to adopt active solar systems if and when they becone economically feasible. There are many books available from which a person who has no experience in building design can obtain an education in passive and active solar design of buildings. One of these is the U.S. Department of Energy, Introduction to Solar Heating - Cooling and Design and Sizing.

This book can give the planner, review boards, and other appropriate officials in the community a more complete education in energy efficient design that can be incorporated into their daily routine and decision making process. A paradox that should be noted is that in order to take maximum advantage of site design concepts for energy efficiency it impliés a relatively low density development. However, many of the principles of site design can be incorporated into higher density development to be used in harmony with other energy efficient design principles previously considered and aimed at attaining higher densities.

\section{CONCLUSION}

This chapter has presented some fundamental concepts and information on the manner in which the effective use of space can contribute towards reductions in energy consumption. As the introductory discussion suggests however, our communities have developed under conditions of cheap energy, when the friction of distance was at its smallest. Thus, the derelopment pattern that exists is entirely inappropriate to the conditions which are expected to exist in the future, expensive energy and increased friction of distance. The job of the planner will be to adapt existing development patterns to accomodate these 
changing circumstances and to plan new physical growth in such a manner that it will not only be efficient unto itself but will support needed modifications to already existing urban forms. The next chapter addresses the mechanisms and resources arailable to the planner to accomplish this task. 
12phylis Myers, "Land Use Policies and Energy Conservation", Conservation Foundation, p. S5.

15 Durwood J. Eaelke, Jr., "Energy Conservation Through Automobile Parking Yanagement", Energy Conservation Project Report, no. 6, (1ay 1976).

$1+$ Ibid., p. - .

15 Ibid., p. 14, Table 6.

${ }^{16}$ In a suit challenging the Clean Air Act Transportation Control Plan for Boston, the U.S. Court of Appeals for the First Circuit rejected an assertion that a regulation mandating that forty percent of the total commercial off-street parking supply remain vacant until $10 \mathrm{a} . \mathrm{m}$., amounted to a taking without just compensation.

17 Real Estate Research Corporation, The Costs of Spraw1, (liashington D.C., U.S. Government Printing Office, April 1974), prepared for HUD, CEQ, EFA.

1S Massachusetts Department of Community Affairs, "Energy Management in Municipal Street Lighting", (March 1977), p. 23.

19 Ibid. pp. 8-10.

20 For more information on sea and land breezes see, Glenn Trewartha, An Introduction to Climate, (New York: McGraw-Hill Company, 1968) pp. 108-110.

${ }^{21}$ For more information see, Arthur N. Strahler, Introduction to Physical Geography, (New York: John Wiley G Sons, Inc., 1973), p. 75: and for a discussion of winds in cities see Nathan Cobb "High Rise in Windy Boston", in New England Magazine, Boston Sunday Globe, October 10, 1976.

22 For more information see Glenn Trewartha, An Introduction

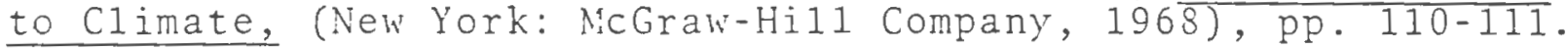

23 American Institute of Architects, Energy and the Built Environment: A Gap in Current Strategies. (Washington D.C., 1974) p. 11.

${ }^{24}$ These principles apply to residential buildings and most commercial buildings. However, commercial buildings and industrial plants which use heat in manufacturing processess or generate heat for other than comfort purposes will operate under different circumstances to be energy efficient. These buildings will want to increase heat loss to be energy efficient for comfort purposes and decrease heat loss in the process. $1974)$.

25 Ralph Knowles, Energy anc Form, (Cambridge: The MIT Press, 
${ }^{26}$ Passire solar energy does not use mechanical porer (e. g.: pumps and fans) but instead uses natural energy flows for transfer of thermal energy into, out of, and through a building. Active systems utilize a mechanical system to transport energy between collectors, storage, and the building. 


\section{CHAPTER. V \\ IMPLEMENTATION RESOURCES AND MECHANISMS}

\section{Introduction}

This final chapter addresses resources and mechanisms that can be used to implement community energy programs. Programs that result from comprehensive planning can only be effective within the Iimitations of resources and mechanisms that are arailable to implement them. When developing programs it is not only necessary to know the community's needs and goals, as determined in the planning process, but it is also important to foresee implementation resources and mechanisms which are required for successful implementation and see that they can be made available.

Implementation mechanisms, as discussed in this chapter, are those authorities, controls, regulations, and laws which the community government can apply to promulgate, initiate and enforce a program. In this chapter, implementation mechanisms refer primarily to the police powers of the community (i.e. zoning, building codes, etc.). Powers that exist or can be established within community governments with regard to these implementation mechanisms are essential to the implementation of some community energy program measures and to the implementation of a comprehensive energy program.

Resources refers primarily to funding. This chapter will address itself to resources that may be available through the federal government through various programs which have been established through federal legislation. Some of these programs may have expired or may not have received appropriations 
from Congress so it would be rise for planners to investigate before proceeding very far along in the program planning and development process. Even programs for wich authorizations have been made may have received reduced appropriations or no appropriations. Some programs are offered on a voluntary basis, that is, all targeted entities are invited to participate. Others are on a competitive basis whereby applications outlining programs must be submitted to the appropriate federal agency and grants are made to those applicants that best meet evaluation criteria. Unsolicited proposals and requests for funding to appropriate federal agencies sometimes meet with success. The best source of information on federal eunding which is available on a competitive basis is the Commerce Business Daily. This is a publication of the federal government in which all federal agencies must place advertisements for bids and proposals for all contracts they want to issue. This publication is issued daily.

\section{IMPLEMENTATION RESOURCES}

Most of the programs which can potentially provide resources to local governments to undertake energy programs are administered by four federal agencies: U.S. Department of Housing and Urban Development, U.S. Economic Development Administration, U.S. Department of Energy, and the U.S. Department of Transportation. Resources available under these programs are in the form of outright grants (some with matching requirements), loans, loan guarantees, below market interest rates, and manpower. Many of the resoruces which will be addressed were not made available specifically for energy program purposes. This parti- 
cularly applies to programs where resources are available for rehabilitation but not explicitly for building retrofits. With the passage of the National Energy Conservation Policy Act of 1978, this situation has begun to change. NECPA has amended various sections of housing legislation to specifically provide for energy considerations. With the growing national concern about our energy situation this adjustment of existing programs may continue. In the meantime, the following listing contains programs which explicitly or implicitly provide funding and/or resources for local energy programs. Local planners should be alertly looking for new Eederal:sources of energy program funding. This will be followed by a discussion of methods for financing weatherization projects and then the second section of this chapter which addresses implementation mechanisms. Resources will be addressed under the following headings:

A. Loans (including guarantees and below market interest rates)

B. Grants

C. Other

A. Loans $^{1}$

Twenty five federal loan programs are listed in this section. Many of them apply specifically to the undertaking of conservation measures. The remainder of the programs are directed towards property rehabilitation. The extent to which property rehabilitation includes energy retrofit work is only implied in program regulations. Loan programs are targeted toward certain geographic areas and certain clientele, for the most part. Loan 
programs which are listed herein include programs which provide outright loans or loan guarantees. In some cases the programs provide lower than market interest rates. In some cases the interest rates are at market levels but the loan making criteria is made less stringent in order to free up money for various retrofit and rehabilitation projects that the money market might not otherwise serve. Most of the loan programs which are listed have loans being made through FHA approved lenders, rather than through federal agencies. Community planners should check with lending institutions which serve their area to see which banks provide these programs. With very few exceptions community energy programs will not be able to rely on the federal loan programs listed herein to make them successful. In most cases these programs should be used to supplement other implementation resources and mechanisms rather than as the core of a program.

1. Section 241 of the National Energy Conservation Policy Act (NECPA) amends Title I of the National Housing Act to provide loan insurance explicitly for purchasing and installing energy conservation improvements and solar energy systems.

2. Section 242 of NECPA amends section 314 of the Federal National Mortagage Association Charter Act to allow GNMA (Government National Mortgage Association) to purchase loans to be used by low and moderated income families for the purpose of installing energy conserving improvements in one to four family units subject to the following provisions: 
-payment of loan must occur within 15 years of date of issue

- interest rates will be at or below maximum interest rates available for such loans

-the loan may not exceed 2,500 dollars

-priority must be given to $10 \mathrm{w}$ and moderate income families (those whose income does not exceed 100 percent of the median income of the area).

3. Section 243 of NECPA amends section 315 of the Federal National Mortagage Association Charter Act to provide the Secretary of the Department of Housing and Urban Development the standby authority to direct GNMA to purchase loans for purchasing and installing energy conservation improvements. These loans would:be available to owners of one to four family dwellings insured under Title $I$ and section 241 of the National Housing Act at interest rates which are established by the secretary of HUD.

4. Section 244 of NECPA amends section 316 of the Federal National Mortagate Association Charter Act to allow GNMA to purchase loans to be made to owners of one to four family houses, and insured under Title I of the National Housing Act, and which are made for the purpose of installing solar energy systems. These loans are subject to the following provisions:

-the amount of the loan does not exceed 8,000 dollars - the period of repayment does not exceed 15 years -at interest rates to be established by the secretary 5. Section 245 of NECPA amends section 302 (h) of the Federal Home Loan Mortgage Corporation Act to permit secondary 
financing by the Federai Home Loan Mortgate Corporation of solar energy and energy conserving improvements for those residential mortgages insured under Title I of the National Housing Act and for such loans to borrower's whose credit worthiness is based primarily on forecasts of income and lacking other security or such loan insurance mentioned above.

6. Section 246 of NECPA amends section 302 (b) of the Federal National Mortgage Association Charter Act to permit secondary financing by the Federal National Mortgage Association of solar energy and energy conserving improvment loans.

7. Section 247 of NECPA amends section 241 of the National Housing Act to provide loan insurance for the purchase and installation of energy conserving improvements, solar energy systems and utility meters in multi family housing whether or not the project is covered by a mortgate under the act. Loans insured under this program are insured subject to the following provisions:

-must bear interest rates which the Secretary determines to be necessary to meet market demands

- cover 90 percent of any loss incurred except for in the case of projects receiving assistance under section 236 or 221 (d) (3) where 100 percent of loss is insured.

8. Section 248 of NECPA makes amendments to various estab-

lished programs to provide increases in mortgage limits

to cover the costs of solar energy systems.

- Section 203 (b) (2) of the National Housing Act is amended to increase the amount of loan permitted to be insured by twenty percent to cover the costs of solar 
energy systems in multí family housing

- Section 501 of the Housing Act of 1949 is amended to give the Farmers Home Administration the authority to increase the amount on any loan which is made, insured or guaranteed under Title $\mathrm{V}$ by twenty percent to account for the increased cost of the purchase of a divelling due to the installation of a solar energy system.

9. Title II of the Economic Development Act of 1965 authorizes loans for the rehabilitation of locally owned structures. This program is administered by the Economic Development Administration. Funding for energy conserving improvements has been made available explicitly under programs administered by EDA.

10. The U.S. Small Business Administration administers a loan program which is aimed at providing a means for small business firms to enter, continue, or expand in the fields of manufacturing, selling, installing, servicing, and developing specific energy measures. This program is provided for by section 7 (1) of the Small Business Act. 11. Section 312 of the Housing Act of 1964 provides low interest long term loans to undertake rehabilitation projects in residential, non-residential, or mixed use properties within approved program areas. Approved program areas include: Neighborhood development projects, urban renewal areas, Section 117 code envorcement areas, and areas approved under the Fair Access to Insurance Requirements Plan. Loans are also available for participants in the Section 810 Urban Homesteading Program. These loans are available at a three percent interest rate to bring properties into conformance with codes and re- 
habilitation standards. "In certain instances they also may be used to bring property above code standards, but the amount of the loan corering general improvements cannot exceed 40 percent of the total loan. There are no income limits on the program although priority is given to low and moderate income families. It is unclear as to the extent that this program can be used for funding weatherization projects.

12. Section 203 (k) one to four family mortgage insurance for home improvement loans outside urban renewal areas. This program is currently inactive due to the ceiling interest rate of 8.5 which was set by 1 aw.

13. Section 235 Mortgage Insurance and Assistance payments for home ownership and project rehabilitation. This program insures loans and prorides payments to lenders to reduce interest rates. This program is aimed at those families which make no greater than 95 percent of the area's median income.

14. Section 221 (d) (2) provides loan insurance for home ownership and rehabilitation of one to four family housing. The program is aimed at low and moderate income families having incomes which are no higher than 95 percent of the area median income.

15. Section 220 (h) provides mortgage and major home improvement loan insurance for urban renewal areas. This program is not very active due to the phase out of urban renewal.

16. Section 225 (e) provides loan insurance for housing in 
declining neighborhoods: Through this program FHA requirements for insurance on housing in older, declining, but still viable urban areas are relaxed.

17. Section 207 provides insurance for loans to public or private developers to construct or rehabilitate multi family rental housing. Frojects must contain at least eight rental units and be located in areas where market conditions indicate a need for such housing.

18. Section 221 (d) (3) and (4) provides insurance for multi family rental housing for low and moderate income families. This insurance program can be used to construct or rehabilitate rental or cooperative housing. Detached, semidetached, row, walk-up, and elevator structures of five or more units are eligible. Section 221 (d) (3) insures mortgages up to 100 percent of the project value for cooperative nonprofit organizations, and up to 90 percent for 1 imited-dividend groups. Section 221 (d) (4) insures mortgages up to 90 percent for limited-dividend groups.

19. Section 236 provides mortgage insurance, interest reductions, operating subsidies to nonprofit or limited profit sponsors for long term ( 40 years) low interest rate mortgages for rehabilitating multifamily housing for lower-income families. Tenants must contribute more than 25 percent of adjusted income to rent.

20. Section 223 (f) can be used to refinance existing indebtedness in projects undergoing moderate renovation. The property owner, through refinancing, can extend 
the terms of the mortgage and increase the principal amount without increasing the debt service thereby providing a margin of capital for renovation.

21. Section 213 provides mortgage insurance for nonprofit corporations, trusts organized to construct homes for a trust member, or trusts to finance the rehabilitation of cooperative housing projects with five or more dwelling units.

22. Section 234 insures mortgages for profit-motivated or nonprofit project sponsors to finance rehabilitation of detached, semidetached, row, walk-up or elevator structures containing at least four dwelling units projects may include nonresidential units, but must be predominantly residential. After rehabilitation, the units in such projects are released from the blanket mortgage, sold to individual owners, and financed seperately.

23. Section 502 provides financing to $10 \mathrm{w}$ and moderate income rural families to repair their owner-occupied single family dwellings.

24. Section 504 provides loans to low income rural households to repair their owner-occupied, single family dwelling.

25. Veterans Administration loan guaranty programs make funding available to eligible veteran homeowners for repairs and improvements to their homes including energy conservation improvements.

\section{B. Grants ${ }^{2}$}

This section lists 21 grants programs which make funding available for undertaking energy conservation projects or re- 
lated projects. As in the federal loan programs all the programs are not directed specifically toward energy conserration projects explicitly. Some of the grants programs listed may be defunct, particularly programs administered by the EDA. The DOT, HUD and DOE programs however, are for the most part funded and in operation. The grants programs, like the loans programs, are targeted towards specific areas and clientele. Funding available through these grants program; particularly the Community Derelopment, Urban Development Action Grants, and the DOE Retrofit grants programs, could form the core of a community energy program.

1. Section 701 of the Housing Act of 1954 provides grants to states and regional planning councils to prepare comprehensive plans. These plans must address themsleves to strategies for growth management and include studies, criteria, and implementing procedures necessary for guiding that growth. Recent language in 701 regulations specifically address the neeed to consider energy conservation. This is a HUD administered program.

2. Section412 of the Energy Conservation and Production Act (ECPA) provides 100 percent grants of up to 800 dollars to weatherize $10 w$ income households, with priority given to elderly and handicapped. Funding is available to families which are within 125 percent of the federal proverty guidelines. The program is administered by the U.S. DOE and run on the local level by Community Action Agency Offices. (Labor is provided by the CAA's and does not figure into the $\$ 800$ project 
cost). Funding is available to owned or rented units. 200 million dollars are authorized each year for FY 79 and 80 .

3. Section 504 of the Housing Act of 1949 provides grants up to $\$ 800$ per dwelling unit for $10 w$ income owners and tenants. Priority is given to low income elderly and handicapped househoids. The program is administered by the Farmers Home Administration. The legislation sets a minimum appropriation of 25 million dollars. Low income families and eligible expenditures are the same as defined under section 412 of the ECPA, and the legislation provides for coordination among weatherization programs run by various federal agencies.

4. Section 222 (a) (12) of the Economic Opportunity Act of 1964 provides a weatherization program which is subject to the same provisions for project costs, eligible expenditures and eligible recipients as the DOE and FHA weatherization programs. This program is administered by the U.S. Community Services Administration and is run locally by the Community Action Agencies (CAA's).

5. Section 251 of NECPA amends section 5 (c) of the U.S. Housing Act of 1937 to provide up to $\$ 10$ million per year for grants to pay for the purchase and installation of energy conserving improvements in existing low income housing. Eligible for grants are those projects which are financed with loans under secgion 202 of the Housing Act of 1959 or which are subject to mortgages insured under section 221 (d) (j) or section 236 of the National 
Housing Act. Projects assisted under section 8 are excluded. Grants will go to those projects which are most in need, as determined by the Secretary of HUD.

6. Title III of the Older Americans Act provides weatherization assistance to the elderly. These monies must come out of the state agency for the elderly grant allocation which is provided with a ten percent match requirement. The elderly agency must include it in their plan to be eligible.

7. The Community Development Act of 1974 provides funding to eligible communities to be used by the community for a number of broad purposes related to community development and maintenance. Among other things, this funding can be used by the community to rehabilitate housing, public buildings, and private buildings through various approaches including provision of low interest loans, grants, refunds or other approaches to be determined by the community. Funding must be spent to meet objectives included in the community Development application. Funding is generally available to those cities with a population of 50,000 or greater. This program is administered by HUD.

8. The section 8 program provides assistance to tenants of leased housing by subsidizing rents. Under this program the owner enters into a contract with HUD whereby HUD agrees to pay that portion of the rent which exceeds 15 to 25 percent of the tenents income. This program can be used for housing requiring severe rehabilitation 
thereby insuring that the owner gets fair market value prices for his investment in rehabilitation projects. This program is administered by HUD.

9. Ten east coast states were selected by to participate in a solar domestic hot water demonstration program. Each state was allocated a number of $\$ 400$ grants to be applied towards the purchase of a domestic water heating solar system. As of this writing each of the states still has a number of grants available. The grants are available to single family homeowners who are willing to purchase a solar system to compliment their conventional system. The program is administered by HUD and run by the state energy office. States that have received funding for the program include all the New England states except Maine.

10. The Solar Demonstration Act of 1974 provides funding for demonstration projects. Funding has been provided for residential and nonresidential projects and has been aimedboth at design and construction. Funding has been made available to architects, developers, builders, and owners under this grants program. Periodically announcements are made of the eligibility in the Commerce Business Daily. Funding is available on a competitive basis and submission of applications is required. The most recent call for applications was April 26, 1979. The program is administered and run by the HUD national office.

11. Crisis Intervention funding is available to be distributed by local CAA's in a program which is administered on 
the federal level by the U.S. Community Services Administration. This funding is available to pick up costs for heating fuels of low income families who are unable to afford it on their budget.

12. Title III of NECPA provides funding, on an equal match basis, for energy audits and the purchase and installation of energy conservation measures in schools and hospitals. It also provides funding to provide energy audits of local government buildings and public care institutions. (Energy audits are an analysis of buildings to determine their energy efficiency.) This program is expected to be funded through FY 1982 for schools and hospitals and through FY 1980 for local government buildings and public care institutions. Funding is available on a limited basis to those applicants which display the greatest need for the funding. Applicantions are made to the state energy office who administers the program on the state level. The program is run on the federal level by U.S. DOE.

13. The proposed Energy Management and Participation Act is currentiy before the Congress. This act would extend many existing programs which are provided under previous energy acts and would provide for comprehensive energy management planning at the state level. This proposed legislation also marks the first time that funding has been proposed for comprehensive energy planning at the local level (other than funding made available to plan and prepare for the impacts caused by specific energy 
related projects through the Coastal Zone Management Act). This act will proride an estimated 5 to 25 million dollars annually through 1984 to selected communities to undertake community energy planning. EMPA is expected to be approved by Congress in calendar year 1979. 14. Title I of the Public Works and Economic Development Act PWEDA of 1965 provides for various public works improvement and development projects including land aquisition, construction, and building rehabilitation. Priority is given to areas which suffer from low imcome and unemployment. Projects which are proposed for grants must create immediate construction job opportunities for the unemployed in the area. This program is administered nationally by the U.S. Economic Development Administration and is run by state agencies.

15. The Urban Development Action Grant (UDGA) program was provided for by the Community Development Act of 1977. This program basically supersedes the Title I Public Works program as it is aimed at similar objectives and is run in a similar manner. The program provides funding to projects which create jobs in older economically stagnating urban areas. The main difference between UDAG and EDA programs is that UDAG requires the stimulation of, or inclusion of, local private investment in proposed projects where PWEDA provided 100 percent funding with no provisions for additional investment. The program is administered by HUD and applications must be submitted to HUD area offices. Large and small cities 
which meet criteria for age and economic hardship are eligible.

16. Section 5 of the National Nass Transportation Assistance Act provides transportation subsidies for capital construction and operations.

17. Section 5 of the Emergency Highway Energy Conservation Act of 1974 pays up to 90 percent of the cost of carpool demonstration projects. Eligible for funding are: systems for matching riders in carpools or vanpools, signing to provide preferential parking for carpools, costs of purchasing vanpool vehicles, costs to promote the program. Carpool programs can be originated by a local government but must have the concurrance of the metropolitan planning organization. Applications must be submitted by the state highway agency to the FHli Division Administrator for that state. No project can be funded for more than one million dollars. More than one project may be funded in a state or urban area.

18. The Federal Highway Act of 1973 authorized funding for construction of bikeways under a formula which provides for a 70 to 90 percent federal share depending on the nature of the project. Pathways that are constructed in conjunction with interstate projects are eligible for higher funding. No more than $2.5 \mathrm{million}$ is allowed to each state per year. Projects must be included in the Transportation Systems Management program wich is prepared by the metropolitan planning organization (MPO) to be eligible for funding as part of an areawide trans- 
$1+2$

portation improvements program. The MPO is the local contact for this program.

19. Section 119 of the Federal Aid to Highway Act of 1974 authorized funding for bikeway demonstration projects whereby the federal government pays up to 80 percent of costs. This program must also be included in the TSM to be eligible for funding (see above). The MPo should be contacted to persue this locally.

20. The Land and Viater Conservation Fund Act of 1965 pays 50 percent of the cost related to aquisition and construction of bikeways for recreational purposes. The U.S. Bureau of Outdoor Recreation administers this program.

21. The Public Works Impact Program, Title I of the Public Works and Economic Development Act of 1965 provides grants that can be used for bikeway construction as can Community Development grants and UDAG grants (see Grants $\# 7,14,15$ in this section).

\section{C. other ${ }^{3}$}

There are three federal programs of note that can potentially be of benefit to the community planner in formulating and implementing community energy prograns. The resources available through these programs are described below.

1. Section 233 of NECPA provides a directive to the secretary of the Department of Labor to provide labor to the maximum extent feasible in support of weatherization programs which are mentioned in "Grants" items \#2,3,4 of this chapter. CETA prime sponsors at the local level 
are responsible to allocate positions for this program. The state labor agency can be consulted to determine who the prime sponsor is for a particular agency.

2. Title II, Part 1 of NECPA provides for a residential conservation program to be run by utilities. This program must be run in accordance with a plan submitted by the state which has been developed consistent to regulations published by the Secretary of DOE. Under the law all large regulated utilities are required to participate in accordance with the state plan. Non-regulated utilities are required to participate either according to state plan or a plan approved by the Secretary of DOE, at the Governor's discretion. The Governor may also submit a plan to address home heating oil suppliers, at his discretion. Services provided under this program include provision of information to residential customers on energy and cost savings arailable through installation of various measures, lists of suppliers and contractors who provide conservation measures, lists of banks which offer loans for conservation measures, on site inspection of residences and suggestions for energy conserving improvements, arranging for contractors to perform work and loans to undertake work, and provisions for repayment of expenses as part of utility bills. This program is due to be in place by January of 1980. The state energy office, governor's office, or division of public utilities will be responsible for administering this program. 3. Section 361 of the Energy Policy and Conservation Act 
of 1975 invites each state to develop a State Energy Conserration Plan. In order to be eligible for funding to implement this plan the state must include eight mandatory measures and prove that it can achieve a reduction of at least 5 percent in the energy consumption projected for 1980. Included among the required programs are some measures that have, direct impact on local governments. These are: statewide mandatory thermal efficiency standards for al1 new construction, mandatory standards governing lighting levels in all buildings which the public has access to, a program to provide for qualified energy auditors of residential buildings and other building types, a program to strive for coordination between all levels of government on energy matters within the state, and a program which is aimed at creating public awareness of the energy conserving measures that can be undertaken. State energy offices have developed considerably through the SECP program and are a good source of technical assistance and information on energy conservation to assist planners in developing community energy plans.

\section{Methods for Applying Resources}

There are several methods which can be employed to apply the previously mentioned resources with other local resources to formulate an effective implementation program. Before devising methods however, it will be necessary to check on the availability of the federal resources and to make some overtures to obtain non federal funding, whether it be public funding or 
- private funding. When investigating the availability of the federal funds it will be necessary to check on the availability of the loan programs which are listed by checking with FHA, HUD, and lending institutions which serve the locality. The availability of grant funding should be checked through the field office or regional office of the administering federal agency. All programs which are listed, and where funding is not explicitly mentioned as being available for weatherization and other energy retro-fit projects, should be investigated because regulations may prohibit such expenditures in some cases.

The various methods for utilizing public and/or private funds for financing the cost of energy conservation improvements come under the headings of loan pooling, revolving loan funds, loan guarantees, interest reduction, deferred payment loans, and interest rate subsidies. ${ }^{4}$ of these approaches, loan pooling usually refers to private funds; revolving loan funds, interest reduction and deferred payment loans usually refers to public funds; and loan guarantees and interest rate subsidies usually refers to combining public and private funds.

Loan pooling involves contributions from lenders to obtain the necessary capital. It is usually aimed at servicing sectors of the population who would not normally be eligible for loans or for financing projects which are not conventional. Participations in the returns on loans would be divided among the contributors according to prearranged formulas. Loan pooling is an approach which allows contributors to share risk and to provide financing for purposes they would not otherwise do individually because of competitive disadvantages it may create. 
Loan pools can be used in combination with public funds as well. Revolving loan funds are usualy set up with public finding, and sometimes with private monies. Revolving loan funds are simply funds which replenish themselves as returns are provided. It is a fund which is dedicated to a particular funding purpose. Loan pools could be established as revolving funds rather than as one time loan funds.

Through the use of public funds, primarily, below market interest rate programs can be established. This simply involves providing a lower interest rate than that which is prevailing on the market so as to encourage potential borrowers, the targeted sector, to take the initiative and obtain a róan. Below market interest rate, or interest reduction, programs are often used with revolving loan programs. Lowered interest rate programs are doubly effective with regard to conservation measures because of the payback which results due to the installation of the measure itself.

Deferred payment loans a re loans which are usually made with public funds. These loan programs allow for loan repayments in a lump sum at some future time, particularly when the property for which the loan was granted is sold. It is usually used in conjunction with large rehabilitation projects and would probably not be a sensible method when funding only conservation projects. This method depends on the future value of property.

Loan guarantees are a method for making private funds availaatle by bringing public funds to bear. In local loan guarantee programs the town will deposit funds with the lender to cover 
- the cost of outstanding guarantees on loans made by the lender. The interest on these deposited funds can be used to make more loans arailable or to reduce the interest rate on loans. To establish this type of program it will be necessary to develop an agreement with the lender to establish loan making criteria and the portion of the loan covered by the guarantee.

Interest rate subsidy is a method of applying public funds with private funds to lower the effective interest rate the borrower pays on a loan. In this type of program a subsidy is used to make up the difference between the actual market interest rate charged by the private lender and the interest rate the borrower pays. The interest rates may be reduced by providing periodic interest subsidies to either the borrower or lender, grants to the borrower to reduce the amount of principal that must be covered by a loan, or through a prepayment to the lender of a percent of the interest due over the term of the loan.

The source of the resources to which these methods can be applied are up to the local planner and the community to produce. Community Development (CD) grants have been a major source of funding to which some of these methods of financing have been applied. Many cities recieving CD funding have developed revolving funds and interest reduction programs (with interest rates as low as 3 percent). The local government can also budget funds or sell bonds in order to finance the programs in addition to utilizing the federal sources which were presented previously. Raising private funds is possible and feasible when programs for which funding is being used has the support 
and strong commitment of community leaders.

\section{IMPLEMENTATION MECHANISMS}

As was stated previously, implementation mechanisms are those authorities and powers that the local government possesses which can be used to implement community energy programs. The purpose in applying these implementation mechanisms rould be to achieve the energy efficiencies which can be obtained through concentrating physical growth, providing proximaty between different land use types, proper site design, and increased energy efficiency of structures.

This section of Chapter $V$ prorides general descriptions of several implementation mechanisms and approaches for their application. All of these implementation mechanisms relate to zoning and/or the police power of the state (and the community) which permits the enactment of legislation to protect the public health, safety, morals and general welfare of citizens. A history of liberal interpretation by the courts has allowed zoning related mechanisms which are discussed below to be adopted as being within the realm of the state's/community's police powers. However, unless the state has enabling legislation which explicitly permits some of the various approaches listed below it may be subject to court challenge. Community planners should investigate the state's enabling legislation (unless it has home rule) to determine whether the authority exists for adopting any implementation mechanisms which will be presented herein.

This section provides a general description of each implementation mechanism. Horever, a reference from which 
further information can be obtäined has been provided with each mechanism and is contained in a footnote. Implementation mechanisms can be of a mandatory nature whereby compliance is required or they can provide inducements to follow energy conserving practices. This section addresses both.

\section{a. The Daris Approach}

The City of Davis California has established specific prorisions relating to energy efficiency considerations in subdivisions. These provisions involve standards for street, widths, street orientation, set backs, fence heights, site landscaping and tree shading. Through these provisions the city of Daris is encouraging energy efficiency in new construction by making sure that streets are oriented east-west, so that solar insolation is available; allowing zero lot lines so that buildings on adjacent properties can share outside walls, thereby minimizing heatloss; providing shading from trees that will be beneficial in the cooling season; eliminating shadows from south facing windows which are collecting heat during the heating season; and reducing street widths to minimize the use of asphalt in construction and to minimize the area which will be absorbing and storing heat. 4

\section{b. Energy Efficiency Checklists}

Checklists can be used by the planning board when reriewing plans of a developer who is requesting permission to subdivide and develop property. This checklist can include the energy efficiency items which were mentioned in the Davis case, above, and also include items such as those listed in figure 
Figure V-1 Energy Conservation Checklist

A. Efficiency of Site Design

1. Most efficient road, water and sower, and electric utility layout

2. Cluster developinent

3. Use of party walls

4. Centralized heating for development

5. Alternative energy source for development

B. Orientution of Developament

1. Land is gently sloping and faces southeast to soutliwest

2. Building(s) fuce southeast to southwest

3. Building(s) positioned in most favorable togographic situstion allowed by existing Iand form (midway up slopes is best)

4. Building(s) in wooded or otherwise shel tered sites rather than open sites

C. Wind Protection for Developments

1. Shelterbults "used or existing

2. Must effective possible shelterbet

3. Most of development within 10-20 times the averaye height of slielterbelt

4. Shelterbelis serve more than one purpose

D. Wind Protection for Individual Quildings

1. Wind screen " $"$ used for each building

2. Wusd scruen opsimal distance from building Inot fut ther than $5 \times$ height or closer than $1 / 2 x$ spresul)

3. Buildiany oriented between $45^{\circ}$ and $90^{\circ}$ prevsiling wind

4. Nunleased fuilding spaces on windward
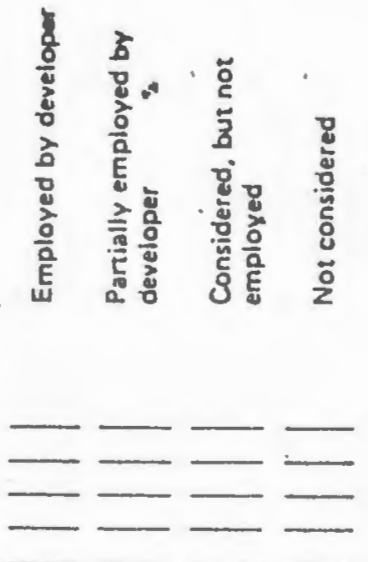

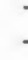
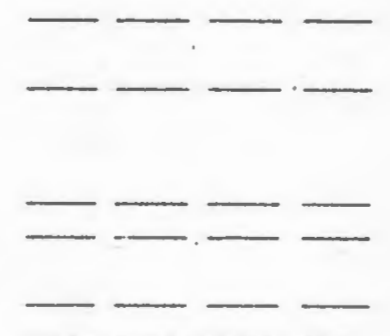

5. Maximum pitched roof areas and minlmum wall areas on windward side of building

6. Optimal wind protection to three sides of building

7. Use of wind barriers that direct cold winter winds away from buildings and direct cooling summer breezes into it

B. Use of snow or other devices lor wind protection

\section{E. Natural Ventilation}

1. Plants or delached structural elements used for directing air flow for natural ventilation

2. Mechanical air conditioning eliminated by using physical devices to manipulate air

F. Shading

1. Outside shading devices used to shade major window areas from 10 A.M. 10 5 P.M. during summer months

2. Deciduous shade trees used for shading placed in optimal location for summer shade

3. Vines used on sunny brick, stone, or concrete walls

4. Grass or other plant materials used against buildings rather than paving

Source: "Slate ol Vernont Enetgy Conservation Guidelinot Service Board and the Ageney of Environmental Conservation (Montpelier, April 1974).

- A thellerbelt is a mass of vee plantings used to reduce wind valocily.

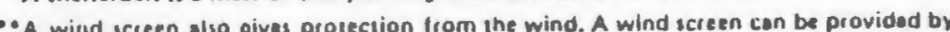
- A wirld screen also givas protection from the wind. A wind seresn can be provided by - building plants or eny combination shereol. 
$v-1$. Energy efficiency checklists can serve to heighten the aliareness of the developer, the community, and the planning board itself with regard to energy efficiency in construction. Such a checklist can also be used as a way of testing the feasibility and reaction to the adoption of similar provisions as mandatory requirements in zoning or subdivision ordinances. ${ }^{5}$

\section{c. Energy Impact Statements}

Energy Impact Statement could be required for submission to the planning board as part of the procedure for subdivision approval. Private developers would be required to address the points such as those contained on the energy checklist, and would be required to explain, in writing or at hearings, why measures were not included in development plans and designs. The developer would be required to present figures on life cycle costs and life cycle energy consumption relating to certain alternatives such as increased insulation levels, use of alternative energy sources, and shading. Preparation of these statements would help the builder/developer to better assess the assets of the aforementioned alternatives and would also provide the consumer with some information about the property's potential for energy reductions through retrofits. These energy impact statements could also be required with the submission of budgets by departments of local government to assess such things as: life-cycle cost and energy efficiency of alternative vehicle purchases; the use of emulsified asphalts and plastic pipe by public works departments; the potential for cost and energy savings by budgeting properly for preven- 
tive maintenance and improved operations procedures in public buildings. 6

\section{d. Density Bonuses}

This is an approach whereby increases in density are allowed in exchange for public benefits from the private developer. It is not a system that encourages increased density of development but allows it to happen where there is growth pressure. Traditionally the public benefits are items such as common spaces, recreational facilities, park areas, and other such facilities. As these items are provided by the developer he begins to accrue points which can be used in exchange for increased density of development. This approach could be used with regard to energy conservation by permitting increased density, mixed uses, and other exceptions to the subdivision ordinance in exchange for more energy efficient design of buildings and site including provision of bikepaths, buffering, shading, and incorporation of solar design concepts. This concept can be applied to various scales of development including a few blocks, such was done in the Greenwhich Street development district in New York City, or projects which contain many acres, such as the new town project of the Levitt Company in Prince George's County, Maryland. In either case criteria of exchange of public benefits for ordinance exceptions should be carefully considered and carefully spelled out. Energy Impact Statements which assess the various alternatives should be required from the developer. ${ }^{7}$ 


\section{e. Performance Zoning}

Performance zoning is a method of zoning which provides flexibility which is not otherwise available in conventional zoning by district area. Performance zoning is a move in the direction of eliminating the lines from the zoning map and the prescribed standards from the ordinance which apply universally to areas without regard for unique circumstances of the area. It is a useful approach from the standpoint of energy conservation because its purpose is to allow for development within the natural carrying capacity of the site. It permits mixed uses and provides some freedom for site and architectural design. This is an appropriate approach because it alrows for energy efficient design. However, it could be improved to require architectural design. This could be accomplished by establishing standards for site design and building design with regard to energy conservation which are similar to those for carrying capacity of the land. Standards regarding carrying capacity refer to erosion, air quality, traffic generation, percolation, height, bulk, and other aspects of site. Energy conscious development would be concerned with use of available insolation, proximaty to services, and concentrations of development. Standards which are acceptable to the community can be established with respect to these considerations as they have been with respect to the aforementioned considerations. Phased development approaches, such as employed in Ramapo N.Y., ${ }^{8}$ is a form of performance zoning only it is dependent on the carrying capacity of the municipal infrastructure rather than the carrying capacity of the land. The Ramapo ap- 
proach involved phasing growth to concide with the arailability of infrastructure. 9

\section{f. Transfer Development Rights (TDR)}

This is a situation whereby the ownership of the land and the right to derelop it are seperate. By seperating these aspects it is possible to direct development to contained areas and reduce development in other areas where it is not desired. TDR works by dividing the community into preservation districts (or sending zones) and receiption districts (or receiving zones). By establishing these districts owners of areas that are to be preserved can sell their development rights (usually to the government) and use the money to support the land while it is maintained in a lower use type. Receiption zones become more dense in development as development rights are purchased. This al1ows land that is best kept in a lower use to be able to afford to stay in that use. It also requires that the receiving areas are true growth areas and provides a check to see that this is truly the market condition. The use of transfer development rights should only be made when the desire for preservation of an area is high. It should also be used in conjunction with a program of preferred taxation in the case of land preservation. Preservation of lands for uses such as localized recreation, agriculture, and wildlife are desirable from the standpoint of energy as well as environment and other considerations. 10

g. Transfer Fee Plan (TFP)

The transfer fee plan is another form of incentive, as is TDR, which seeks to allow preservation of areas as well as 
direct growth to areas of concentration. The TD! differs from the TDR in that it is directec towards private capital paying the fee for development rights whereas in TDR it is the local goverment that usuali: Furchases the development rights from the land owner and attempts to seli them to private developers. TFP provisions charge the purchaser of the land for the right to buy in preserve areas. The fee is then placed in a fund which is split among all those land owners participating in the preserve to help them afford to maintain the land in a lower use. Land that is sold without the permission of the preserve members gets charged an additional fee. This program, as in the case of IDR is only effective where the desire to preserve land in a lower use is predominant. 11

\section{h. Mixed Uses and Clustering}

Most of the aforementioned mechanisms have been aimed at mixed uses and clustering of land uses through incentives. However, the planning philosophy and the philolophy of many individual life styles have exerted pressure to allow for mixed uses and clustering on its own. In many places this pressure has sought an outlet from conventional zoning practices. Planned Unit Development and Clustering are two planning approaches which have sought the same means as energy efficient development for different purposes. These types of development have as their central tenet the desire to achieve efficient use of land through mixing uses, increasing the density of uses, and making open spaces available for use by the nearby, adjacent, public. In this type of development the average density for a parcel of land is usually kept the same as in conventional 
zoning conditions which occur in the zoning ordinance. However, uses are grouped to make more efficient use of the land available. Where HUD usually implies mixed uses, clustering usually refers only to residential uses. 12

\section{i. Building Codes}

The use of thermäl efficiency standards in building codes has become predominant since the passage of the Energy Policy and Conservation Act (EPCA) of 1975. This Act called for the establishment of mandatory termal efficiency standards on a statewide basis in all 50 states. As of this writing the majority of states have complied with this voluntary program with the help of funding which was made arailable through EPCA. This legislation was passed subsequent to the issuance of contracts to the major model building code groups accross the nation and an engineering organization which established the standards. The code provisions call for buildings to meet either prescribed standards for insulation levels in new construction or performance standards for overall $U$ values of building components. A new standard is being developed under the auspices of U.S. DOE and HUD which will increase the stringency of the EPCA required standard and provide more flexibility in compliance by making it a standard based totally on building performance. This standard is being developed under ECPA, Title III and is called BEPS (Building Energy Performance Standards). If Congress exercises its sanction no HUD funding will be made available within states which do not adhere to BEPS. 
These are some of the resources and mechanisms available for implementation of the programs that might be developed as a result of the planning pursuec and the policies established through employing tools used in Chapters I-IV. Much information has been presented within the Chapter $V$ and within the overall document. However, there are many more details that will have to be addressed when attempting to undertake a comminty energy program. Undertaking such a program requires much commitment and many resources, when done in a comprehensive manner. However, it may be the best first step towards drawing the attention of government officials and the people of the community to the role of the community and the benefits of undertaking energy efficient planning. 


\section{CHAPTER T}

Footnotes

Myjor references which provided infornation on loan prograns and used in this chapter are: National Energy Conservation Policy Act, Title II, Part 3, PUBLIC LAI 95-619-Nov. 9. 197s; The Bureau of National Affairs, Inc., "Housing Rehabilitation and Neighborhood Conservation", Housing \& Development Reporter, HDR RF-95 (October 10, 1977): 14: 0011.

2Major references which provided information on grant programs and used in this chapter are: National Energy Conservation Policy Act, Title II Part 2 and Title III, PUBLIC LAW 95-619-Nol. 9. 1978; Curtiss Priest and Maria R. Eigerman, principal authors, "The Energy lista; Policy Perspectives on Energy Conservation Through Land Use Management", (report prepared for FEA and ERDA byT and E of Cambridge, MA, June 1976): 141-194; Federal Regional Council of New England, "Guide to Federal Consumer Energy Assistance in New England", Feb. 1979; Federal Highway Administration, "Federal Aid Highway. Program Manual", June 1976; Carl Berkowitz and Halter Kraft," "The Bicycle", Practicing Planner, 8 (Narch 1978) 30-35.

3 Energy Policy and Conservation Act, Title III, PUBLIC LAW 94-163-Dec. 1975; National Energy Conservation Policy Act, Title II, Part 1 .

${ }^{4}$ Gloria Shepard McGregor, "Davis California Implements Energy Code", Practicing Planner 6 (Feb. 1976) 24-27; Ordinance No. 784, Ordinance No. 787, Resolution No. 1833 enacted by the City Council of the City of Davis.

${ }^{5}$ Corbin Crews Harkood, Using Land to Save Energy, Environmental Law Institute State and Local Energy Conservation Project, (Cambridge, MA: Ballinger Publishing Company, 1977) 100.

6 Ibid. pp. 193-202.

${ }^{7}$ Dan Yurman, "Can Density Bonuses Pay Off?", Practicing Planner, 6, (April 1976) 14-21; Marvin Markus and John Pettit, "Urban Design Through Zoning" Planners Notebook, 2 (Oct. 1972).

${ }^{8}$ Charles L. Crangle, "The Ramapo (Rockland County, NY) Experience", printed in Northeast Regional Center for Rural Development, The Proceedings of the Conference on Rural LandUse Policy in the Northeast (October 1974) 206-210.

${ }^{9}$ Kevin Lynch, Philiip D. Herr "Performance Zoning", Planners Notebook, 3 (oct. 1973); Lane Kendig, "Performance Zoning: An Update on Euclid", Planning, 32 (Nov. 1977) 18-21; Charles Reiss and Michael Kwartler, "Housing Quality Program Puts Human Scale Into Residential Zoning", Planners Notebook, 4 (Dec. 1974). 


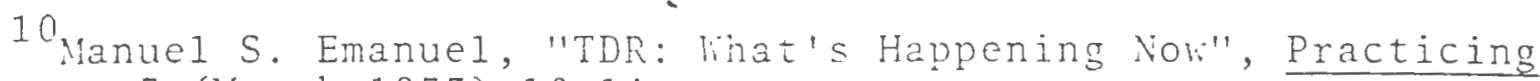
Planner, 7 (Narch 1977) 10-14.

${ }^{11}$ Robert $W$. Burchell, Planned Unit Develonment, (New Jersey: Center for Urban Policy Research, 1973); Jan. 2. Krasnowiecki, Legal Aspects of Planned Unit Residential Development, (liashington: Urban Land Institute, 1965.

${ }^{12}$ Grant P. Thompson, "Design Features, Shading, and Orientation for Energy Conservation", ECP Report, 7 (Sept. 1976); Arthur D. Little Inc. Energy Conservation in New Building Design: An Impact Assessment of ASHRAE $\subseteq 0-75$, prepared for the Federal Energy Administration; Arthur D. Little, An Energy and Economic Assessment of HUD's Minimum Property Standards, prepared for the Federal Energy Administration, October 1976: City of Chamaign, Illinois, "An Ordinance Adopting the Campaign Code for Energy Conservation in New Building Construction", Council Bil1 No. $78-92$. 


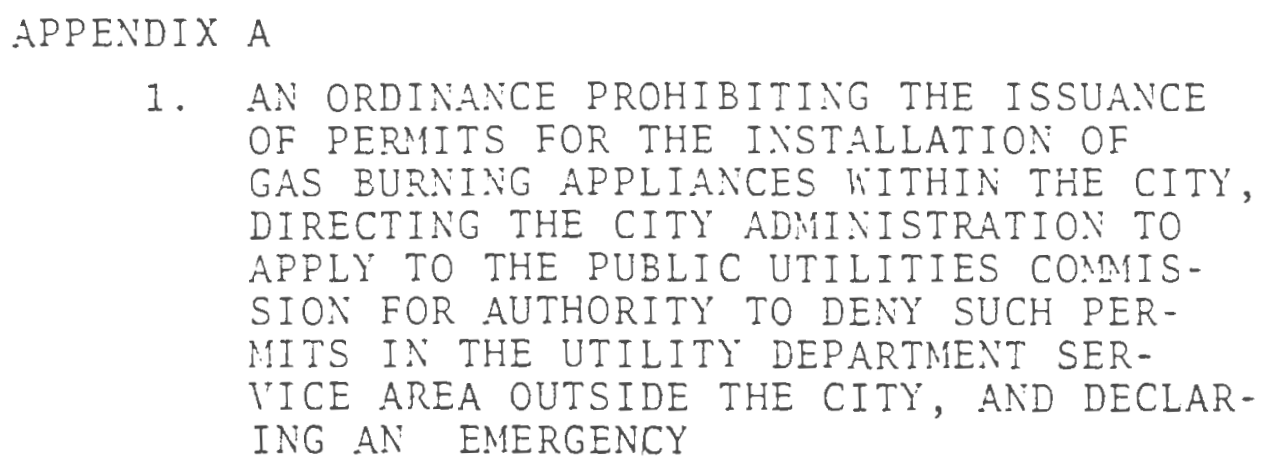


AN ORDINANCE PROHIBITING TIIE ISSUANCE OF PERMITS FOR THE INSTALIATION OF GAS-BURNING APPLIANCES WITHIN THE CITY, DIRECTING THE CITY ADMINISTRATION TO APPLY TO THE PUBLIC UTILITIES COMMISSION FOR AUTHORITY TO DENY SUCH PERMITS IN THE UTILITY DEPARTMENT SERVICE AREA OUTSIDE THE CITY, AND DECLARING AN EMERGENCY.

WHEREAS, the Utilities Department of the City of Colorado Springs has been notified by its supplier of natural gas, Colorado Interstate Corporation, that the available supply of gas for the fiscal year of 1973-1974 is severely limited. The Utilities Department has calculated that the available supply will be barely enough to serve existing firm customers and committed volumes for the coming fiscal year 1.97-1974; and

WHEREAS, new building construction is proceeding at a tremendous rate, almost all of which plans to use natural gas for space heating. If such new construction continues unabated and gas appliances are permitted therein, the available supply of natural gas will be insufficient to serve their needs as well as existing customers.

NOW, THEREFORE, BE IT ORDAINED BY THE CITY COUNCIL OF THE CITY OF COLORADO SPRINGS:

Section 1. The issuance of permits for natural-gas-burning appliances in new construction is hereby prohibited in the City of Colorado Springs until further notice. Permits for the replacement of existing appliances shall be issued, provided such new or replacement appliance is of no greater capacity than the old or replaced appliance.

$-1-\quad 6 / 27 / 73 \quad 2 d$


Section 2. The City Administration is directed to immediately proceed with all necessary applications to the Public Utilities Commission of the State of Colorado requesting permission to deny the issuance of further natural gas appliance permits in the area served by the City of Colorado Springs Public Utilities Department, Gas Division.

Section 3. Because of the natural shortage of natural gas and the inability of the City's supplier to supply more than a limited supply of natural gas for the fiscal year of 1973-1974, the Council hereby finds, determines and declares that a public emergency exists with reference to this ordinance and that this ordinance is necessary for the immediate preservation of the public peace, health and safety and accordingly the same is hereby passed as an emergency ordinance to be effective forthwith upon its passage, as provided by the Charter.

Introduced, read, finally passed as an emergency ordinance, adopted and approved this 28th day of June_ Ju_ , 1973.

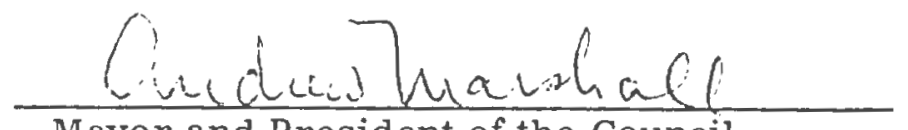

Mayor and President of the Council

ATTEST:

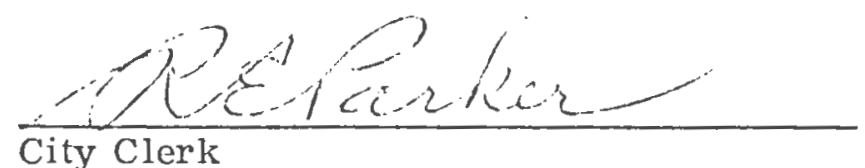


I HEREBY CERTIFY, that the foregoing ordinance entitled "AN ORDINANCE PROHIBITING THE ISSUANCE OF PERMITS FOR THE INSTALLATION OF GAS-BURNING APPLIANCES WITHIN THE CITY, DIRECTING THE CITY ADMINISTRATION TO APPLY TO THE PUBLIC UTILITIES COMMISSION FOR AUTHORITY TO DENY SUCH PERMITS IN THE UTILITY DEPARTMENT SERVICE AREA OUTSIDE THE CITY, AND DECLARING AN EMERGENCY" was introduced, read, finally passed, adopted and approved as an emergency ordinance and ordered published at a regular meeting of the City Council of the City of Colorado Springs, held on the 28 th day of June, 1973, and that the same was published in full in the Colorado Springs Sun, a newspaper published and of general circulation in sald City on June 29, 1973. IN WITNESS WHEREOF, I have hereunto set my hand and affixed the seal of the City this $28 \mathrm{th}$ day of June, 1973.

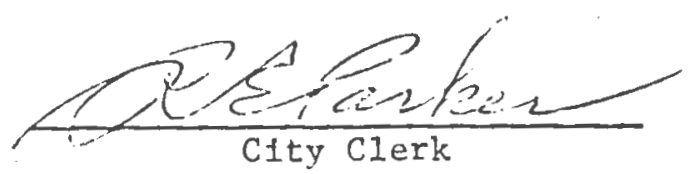


APPENDIX C

1. ENERGY INTENSITY (EI) IN STATE AND LOCAL PROCUREMENT FROM INDUSTRY ESTIMATED FOR 1980

2. 1975 ENERGY USE PER DOLLAR OF VALUE ADDED

3. 1975 PURCHASED ENERGY COSTS AS PERCENT OF VALUE ADDED

4. Outline of Census Bureau Energy Related Statistics

5. Industrial energy Assessment Survey

6. ENERGY EMBODIMENT PER UNIT OF MLATERIAL

7. Energy Assessment Survey: Residential

8. Building Condition Survey 


\begin{tabular}{|c|c|}
\hline Incustry & $E[$ \\
\hline New Const., liighwatys & $(110)$ \\
\hline New Const., Nonres;icluntial. & (63). \\
\hline New Const., Pub. Urilit les & $(75)$ \\
\hline Mant. Const., Other & $(54)$ \\
\hline New Const., Other & (81) \\
\hline New Const., Residential & $(52)$ \\
\hline Notor velicles \& l'arts & $(58)$ \\
\hline llospitals & $(48)$ \\
\hline Wholesille Trade & $(3 i)$ \\
\hline Med., llealth Services & $(44)$ \\
\hline Air Transport & $(180)$ \\
\hline Hisc: Business Services & $(2.5)$ \\
\hline llighway Passngr. Trans. & $(63)$ \\
\hline Sook publishing & $(39)$ \\
\hline Drugs & (41) \\
\hline Office supplies & (67) \\
\hline Paper Nills & $(155)$ \\
\hline c]eaning p'reparations & $(73)$ \\
\hline Reul Estate & $(22)$ \\
\hline Meat Products & $(62)$ \\
\hline Notor Freight Transport & (43) \\
\hline -Inorganic-0rganic Chem. & $(206)$ \\
\hline Tublic lildg. Furniture & $(55)$ \\
\hline Commercial Printing & (61) \\
\hline Misc. P'rofessional Services & $(24)$ \\
\hline Post office & (35) \\
\hline rommuniditions & $(16)$ \\
\hline Fertilizer & $(122)$ \\
\hline Educational Service & $(54)$ \\
\hline Auto Repair & $(46)$ \\
\hline Tires & (85) \\
\hline Inctors, Dentists & (14) \\
\hline Apparel from Purcliased Mat. & (43) \\
\hline Machine Shop Products & $(47)$ \\
\hline Misc. Rubber Products & $(82)$ \\
\hline Metal office Furniture & $(60)$ \\
\hline Chem. \& Fert. Mineral Mining & $(187)$ \\
\hline Photographic Equip. & $(40)$ \\
\hline Glass Products & $(92)$ \\
\hline Insur. Carriers & (20) \\
\hline Railroad & (73) \\
\hline Service Industry Machines & $(56)$ \\
\hline Water Transu. & $(230)$ \\
\hline Const. Machinery & $(58)$ \\
\hline Trnvelopes & $(68)$ \\
\hline Asiciculeural Clienicals & $(122)$ \\
\hline Mefrig. Machinery & $(58)$ \\
\hline Hotors, Generators & (54) \\
\hline llomprofit org. & $(55)$ \\
\hline H11, MjLk & (55) \\
\hline Wriectric Linns & (39) \\
\hline 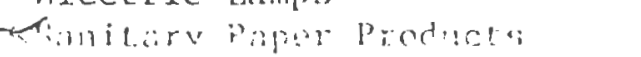 & $(79)$ \\
\hline
\end{tabular}

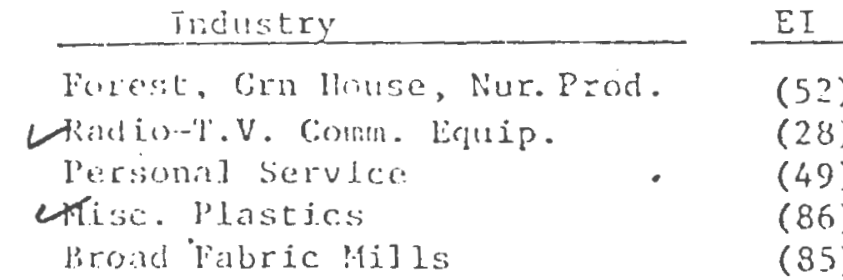

(80) 
Table [II-A, jage: 2

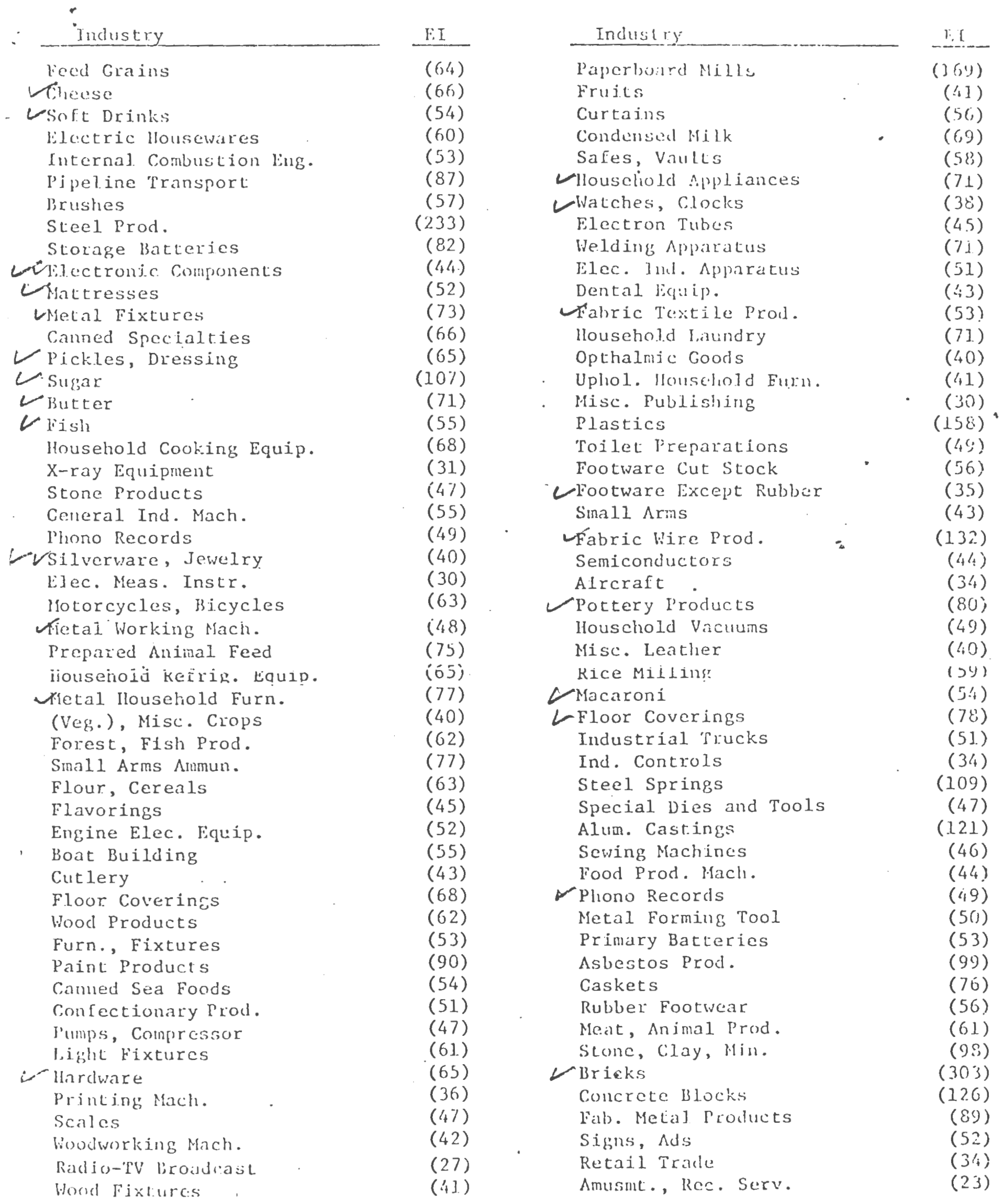

Oarce: SLI, Op.cil. Pp.43-47. J950 calculations based on SPt formula and data frco...

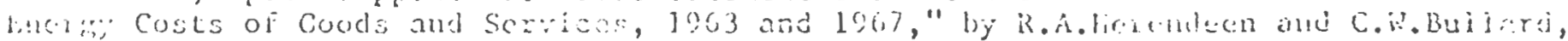
Ir, liniversity of Illinois (Yovember 1.9?4). 
TABLE 4.

1975 ENERGY USE PER DOLLAR OF VALUE ADOED

( $10^{3}$ titus/\$ Value Added)

STATE

SIC

CODE

CT

MA

NH

RI

VT

20

21

22

23

24

25

26

27

28

29

30

31

32

33

34

35

36

37

38

39

TOTAL

\begin{tabular}{|c|c|c|c|c|c|c|}
\hline & & & & & & \\
\hline 9.10 & 15.03 & 23.05 & 1.52 & .26 .61 & 47.39 & 10.05 \\
\hline - & $=$ & & - & - & - & 5.04 \\
\hline 29.10 & 27.08 & 27.76 & 20.68 & 31.47 & - & $2 \vdots .36$ \\
\hline 4.88 & 2.72 & - & - & - & - & $\therefore .18$ \\
\hline 47.72 & 10.43 & 18.69 & 12.07 & - & 18.75 & 21.93 \\
\hline 5.66 & 10.50 & - & 15.87 & - & 15.16 & $\bar{i} .35$ \\
\hline 36.43 & 35.08 & 119.71 & 83.96 & 38.99 & 38.18 & 67.29 \\
\hline 4.17 & 2.96 & 7.62 & 5.09 & 3.32 & 4.67 & 3.55 \\
\hline 14.48 & 21.76 & - & 22.08 & 20.43 & - & 61.51 \\
\hline - & - & - & - & - & - & $13: 52$ \\
\hline 10.60 & 12.18 & 19.88 & 9.25 & 8.57 & 12.83 & 16.59 \\
\hline- & 8.34 & 8.45 & 11.64 & - & & 7.07 \\
\hline 30.18 & 21.35 & $8 E .02$ & 39.22 & 57.71 & 21.64 & $75.5 y$ \\
\hline 31.92 & 13.41 & - & - & 13.03 & & 73.13 \\
\hline 8.02 & 10.78 & 7.45 & 4.15 & 8.24 & 4.00 & 11.77 \\
\hline 6.17 & 3.87 & 5.47 & 4.67 & 6.02 & 4.64 & 0.42 \\
\hline 4.31 & 4.81 & - & 2.78 & 5.11 & - & 6.54 \\
\hline 4.93 & 8.71 & - & 11.01 & 8.53 & - & 7.70 \\
\hline 3.82 & 4.38 & - & 2.84 & 6.75 & - & 4.93 \\
\hline 9.14 & 6.02 & - & - & 2.14 & - & 5.81 \\
\hline 9.70 & 10.11 & 47.35 & 16.15 & 10.98 & 13.53 & 27.25 \\
\hline
\end{tabular}

Source: U.S. Department of Comnerce, Bureau of the Census, Annual Survev of Manufactures 1975.

NOTE: (-) indicates data not available. 
TABLE 5 .

1975 PURCHASED ENERGY COSTS AS PERCENT OF VALUE ADDED

STATE

SIC

CODE

20

21

22

23

24

25

26

27

28

29

30

31

32

33

34

35

36

37

38

39

TOTAL
CT

$M A$

ME

NH

0.5

$-$

6.2

1.5

3.9

4.2

18.7

2.4

5.8

4.0

3.6

11.5

$-$

1.9

2.1

1.4

4.8

1.9

1.8

4.6

$\overline{10} .6$

$\begin{array}{ll}3.3 & 2.3 \\ 3.4 & 3.4\end{array}$
2.8

-

$-$

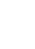


A major element of the Census Bureau's statistical program consists of censuses conducted every 5 years which provide benchmark statistics for agriculture, manufacturing, mining, wholesale and retail trade and selected services, sectors of the transportation industry, and State and local governments. These statistics are used to study the economy in depth and permit a detailed examination of specific industries. The censuses generally provide the framework for intercensal monthly, quarterly, and annual programs which provide important information for selected sectors of the economy. In response to data user needs, the Census Bureau attempts to meet many requests for special tabulations and the development of statistical data on a one-time basis.

In the canvass of the quinquennial economic censuses, intercensal surveys, and special survey and tabulation requests, the Bureau does collect and have available information related to energy and is currently involved in developing several new programs in this area. The kinds of data developed are summarized in the attached outline, "Census Bureau Energy-Related Statistics:" Highlights of the programs involving energy-related data are summarized below:

1. The Census of Mineral Industries, part of the quinquennial economic censuses, has been published at regular intervals since 1840 and provides detailed information on coal mining and oil and gas operations including expenditures and drilling statistics. The final report for $0 i 1$ and Gas Field Operations from the 1972 census includes data on number of wells operated by geographic area; drilling statistics for oil, gas and gas condensate, dry and service wells as reported by operators; and drilling statistics for exploratory and developmental wells as reported by operators, by type of well, geographic area, and depth range.

2. An Annual Survey of $0 i 1$ and Gas Expenditures provides estimates of expenditures separately for the exploration and development of crude petroleum and the exploration and development of natural gas. Originally requested by the Senate Commerce Committee in 1972 in order to determine the impact of the natural gas price ceiling on natural gas exploration and development, these data are now provided annually.

3. In the industrial sector, the Census of Manufactures provides information on petroleum refining and related industries. In addition to general statistics, detailed information on quantity and value of products and materials consumed are provided. Many of the 450 industries include data on consumption of petroleum products or derivatives of petroleum products as raw materials consumed in the manufacturing process. 
4. The Annual Survey of Manufactures provides selected information on petroleum and related industries as well as cost of purchased fuels and electric energy used by industry groups.

5. A special report on fuels and electric energy containing information on fuels consumed in 1971 by type of fuel by consuming industry and by geographic area was published as part of the 1972 Census of Manufactures. A similar report is being developed as part of the 1974 Annual Survey of Manufactures. Availability of selected information is expected by the end of the year.

6. The Current Industrial Reports program includes a bi-annual survey on Sales of Lubricating and Industrial $0 i 1 s$ and Greases and an annual survey on Asphalt and Tar Roofing and Siding Products. Other monthly, quarterly, and annual surveys in this series provide information related to energy consumption (i.e., plastics products, supply and distribution of snythetic rubber and synthetic fibers).

7. The statistics on construction activities include an annual survey of characteristics of new one-family homes which provides information on major types of heating fuel used in new one-family houses. Similar data were collected in the 1970 census for all of the Nation's housing stock. Information on types of heating fuel used for new multi-family buildings started in 1974 has been published. Collection of these data will be continued. By the end of the year, we plan to publish data on types of fuel used to heat and air-condition privately owned nonresidential building projects in the report "Value of New Construction Put in Place." We are collecting similar information for State and local government building projects and will start publishing information for this sector by mid-1976.

8. In the foreign trade program, export and import data are published for commodities such as petroleum products, coal, natural gas, and nuclear materials as well as machinery and equipment which can be used in mining, drilling, refining and production of energy-related products. These statistics are published on a monthly and cumulative basis at various levels of commodity detail by country of origin for imports and country of destination for exports. The data are based on official import and export documents required to be filed with the U.S. Customs Service.

9: Data on the retail and wholesale distribution of fuels--such as the number of gallons of gasoline sold by service stations--are being published based on the 1972 Economic Censuses. Information is also being developed on distribution outlets for petroleum products. A survey of gasoline service stations is being conducted for the Federal Energy Administration to determine the gallonage sold each month, categorized by sales by dealers of branded and unbranded gasoline. 
10. Statistics on transportation activities include a Truck Inventory and Use Survey that includes information by type of truck, type of fuel used and miles driven. Additionally, the 1972 National Travel Survey provides estimates of nonlocal travel by type of destination.

11. The census of agriculture includes farm expenditures for gasoline and other petroleum products.

12. An important feature of our program in State and local government statistics is information on tax revenues by energy type, intergovernmental revenues from energy source, and expenditures for utilities.

13. In addition, the Bureau's demographic and social data collection activities, including both the 1970 Decennial Census program and the monthly Current Population Survey, provide statistics on the general population that have a direct relationship to the current energy crisis. For example, the 1970 Decennial Census data provide information on the geographic distribution of the population and the density of population settlement. Information from the cénsus on the current residence of the population, on their place of work, and on their means of transportation to work will be of great value in determining gasoline use and allocation. Commuting data are available for counties and cities showing the number of persons driving their own cars to work, riding in carpools, and using public transportation. The Annual Housing Survey, both at the national level and in 21 selected SMSA's, contains even more extensive commuting data (e.g., including distance and time from work) on a current basis. The 1970 census also provided a wide variety of information on how America is housed--number of rooms, type of heating equipment, and the presence of energy-using kitchen and laundry equipment to mention only a few. Current national data concerning labor market participation, the occupation and industry of the employed, and personal and family income are also collected by the Bureau. These data could provide indirect measures of some of the effects of the current energy situation.

To put into proper perspective the description of energy-related data compiled by the Census Bureau, brief reference should be made to general areas of information needed in respect to energy problems that are not characteristically compiled by the Census Bureau. Historically, the Bureau has not engaged in regular data collection on subjects such as prices or profits which are covered by other administrative or regulatory agencies, or for which technical or engineering knowledge is required such as in determining oil and other mineral reserves. 
The following describes the Census Bureau's economic data program in the areas of production, distribution, and consumption.

I. Manufacturing and Mining

A. 5-Year Economic Censuses (General economic statistical program covering all the individual industries in manufacturing, mining, retail, wholesale, selected services, and construction.) $\frac{\text { Mandatory }}{(13 \text { USC }}$

---Consumption of electricity in manufacturing and mining.

---Consumption of fuels (quantity and cost) for heat and power in manufacturing (1971) and mining (1972).

---Consumption or use of fuels (quantity and cost) in the industrial process.

Crude oil in Refineries (SIC 2911)

Fuel Products (Benzol, Propane, etc.) used by major consuming industries

---Shipments (quantity and value) of specific products of mineral industries and manufacturing

Coal

Crude oil

Refined petroleum products (gasoline, kerosene, etc.)

Petroleum based chemical products

---Development and exploration expenditures in mining for - petroleum and natural gas industry. 
---Special types of data (crude petroleum and natural gas industries only)

Royalty payments (collected in kind)

Disposition of natural gas production

Number of wells operated

Lease tanks and stocks

Drilling statistics

Number of wells drilled by type (oil, gas, dry, service) and depth range

Depth of wells drilled (by types and depth ranges)

Costs of wells drilled (by types and depth ranges)

Sources of funds for drilling

Special sample survey data on a net working interest

basis covering exploration expenditures and assets

B. Annual Survey of Manufactures

General economic information for all industries and for industry groups by area including refining (SIC 2911) and major chemical industries producing processed fuel products.

---Shipments (value only) classes of products, e.g.

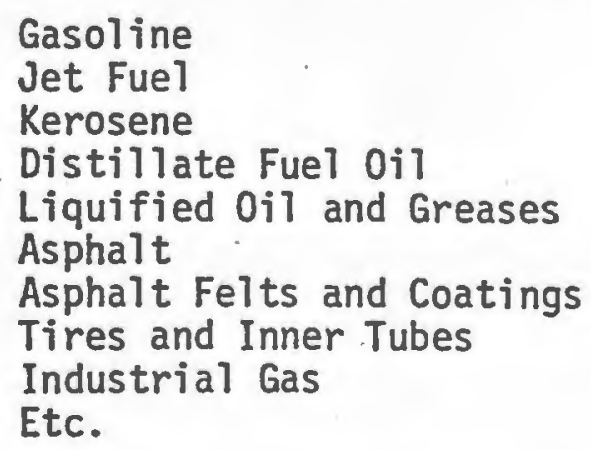

---Cost of fuels used by Industry

---Quantity and cost of electric energy used by Industry

--Consumption of fuels (quantity and cost) for heat and power in manufactures 
C. Annual 0 il and Gas Survey

A survey of the domestic crude petroleum and natural gas extraction industry. Statistics are cross-classified by type of producing property (oil, gas, or combination) and by degree of owner operation. Separate statistics are provided for offshore areas and Alaska.

---Expenditures

\section{Exploration \\ Development \\ Production}

---Revenues

---Sales Volumes

---Assets

D. Other Survey Data Related to Energy

1. Annual Current Industrial Reports (energy-related)

*MA-29C (biennial) Sales of Lubricating and Industrial 0ils and Greases

MA-30D Shipments of Selected Plastics Products

MA-33L Insulated Wire and Cable

MA-22F Textured and Spun Yarn Production

$\triangle M A-34 N$

Selected Heating Equipment

$M A-22 G$

Narrow Fabrics

$M A-35 M$

Air-Conditioning and Refrigeration Equipment

$M A-36 A$

Switchgear, Switchboard Apparatus, Relays, and Industrial Controls

$M A-36 E$

Electric Housewares and Fans

$M A-36 F$

Major Household Appliances

$M A-36 L$

Electric Lighting Fixtures

$M A-29 A$

Asphalt and Tar Roofing and Siding Products

$M A-36 N$ Selected Electronic and Associated Products

$M A-30 E$ Plastic Bottles

2. Quarterly Current Industrial Reports (energy related) Voluntary

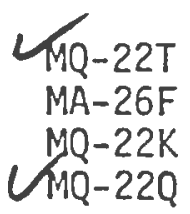

Textile Fabrics

Converted Flexible Packaging Products

Production of Knit Cloth

Carpet and Rugs

*Voluntary 
3. Monthly Current Industrial Reports (energy-related)

Products or by-products of the petroleum industry as reported in the following:

M28A Inorganic Chemicals

M28B Inorganic Fertilizer Materials and Related Acids

M28F Paint, Varnish, and Lacquer

M30A Rubber: Supply and Distribution for the United States

$4122 A$

Woven Fabrics: Production, Inventories, and Unfilled Orders

M22P

Cotton, Manmade Fiber Staple, and Linters

Shipments of Thermoplastics, Pipe, Tube and Fittings

II. Retail and Wholesale Trade

Except where otherwise indicated below, the data described are collected as part of the quinquennial economic censuses. The last such census was published covering 1972. Comparable data will be collected in the 1977 census.

\section{A. Gasoline Service Stations}

1. Number of s.tations, number of gallons of gasoline sold and number of pumps; by state and selected counties and selected SMSA's.

2. Number of gallons of fuel sold (other than gasoline) and number of stations selling such fuel; by State and selected counties and selected SMSA's.

B. LP Gas Dealers

1. Number of establishments, LP gas bulk storage capacity, gallon sales of LP gas; by Divisions and States. (Planned for 1977.)

2. Number of establishments selling bottled LP gas, by selected States. (Same as B1 above.)

C. Fuel 0il Dealers--number of establishments, gallon sales of LP gas, light fuel oil and heavy fuel oil, other types of fuel oil; by selected States. 
H. General statistics (number of establishments, total value of sales (and of inventory for wholesale), payroll, employment) for individual kinds of retail, wholesale, and selected service industries are compiled by State, SMSA, county, and city, with less kind-of-business detail for the smaller areas. Kind-of-business categories included are those involved in the distribution or use of fuel products, e.g. -

7. Retail Trade: gasoline service stations, motor vehicle dealers, mobile home dealers, tire, battery and accessory dealers, boat dealers, and utility : trailer dealers, motorcycle dealers, fuel oil dealers; LP gas dealers, other fuel and ice dealers;

2. Wholesale Trade: petroleum bulk stations and terminals, other petroleum products wholesalers, motor vehicles, parts and supplies metal service centers, coal and other mineral and ores, chemicals and other allied products; and

3. Service industries: automotive rental and leasing, automobile parking, automotive repair and services, camps and trailering parks, equipment rental and leasing services, hotels and motels, and travel agencies.

(Data presently available for both 1967 and 1972.)

I. Special reports based on the quinquennial censuses are developed for individual industries. (1972 data scheduled for release in early 1976.)

7. Automobile and truck rental and leasing without drivers; source of receipts, types of vehicles on short-term rental vs. leasing (except finance), and number of vehicles in fleet; by selected SMSA.

2. Automobile parking lots and structures: parking facilities; by selected SMSA.

3. Automotive repair establishments; source of receipts: U.S. 
D. Petroleum Bulk Stations and Terminals (Wholesale Trade)

1. Number and total dollar sales by type of bulk station (cooperative, independent, comission, and salary) (Information for SFAR available for 1972 only.)

2. Storage capacity and type of fuel (aviation gasoline, motor gasoline, special naphthas, jet fuels, kerosene, distillate fuel oils, residual fuel oils); by county and State. (SFAR by storage capacity size for 1972 only.)

3. Number of gallons sold by type of fuel; county and State. (Same as Di above.)

4. Number of establishments by primary method of receiving all liquid products (tank truck, tank car, pipeline, barge, or tanker); and gallons of lubricating oils and greases blended by State. (Same as DI above.)

5. Dollars sales of petroleum products by type. : (Planned for 1977.)

E. Retail Establishments--Dollar value of sales of gasoline, other automotive fuels, motor oils and greases, LP gas and other household fuels (for selected kinds of business with detail varying by kind of business); by State and SMSA.

F. Monthly sales of gasoline by gasoline service stations. This survey of gasoline service stations has been conducted on a monthly basi-s since October 1974. It determines the gallonage sold, the dollar volume gasoline sold, and the number of retail outlets, categorized by (refinery) branded gasoline sales, by independent dealers and all other sales, Effective with data for November 1975, price per gallon was collected. The Census Bureau is serving as the collecting agent for the Federal Energy Administration.

G. Monthiy sales and inventories of merchant wholesalers of Petroleum and Petroleum Products (excluding bulk stations). 
4. Travel agencies: statistics by size and type of services, source of receipts; by selected SHSA.

J. Sample surveys provide monthly national estimates on total dollar volume of sales of establishments classified by kind of business, including gasoline service stations and the larger kind of business among those listed above; limited kind-of-business detail is provided by geographic division.

III. Export and Import Statistics

Export and import statistics as published on energy-related commodities such as petroleum and products, coal, natural gas, and nuclear materials, as well as machinery and equipment which can be used in mining, drilling, refining, and production of energy. Statistics on electric energy are not compiled by Census but are available from the Federal Power Commission.

The statistics are released at various levels of commodity detail in a variety of arrangements (e.g., commodity by country, comodity by Customs District, etc.). Details on the various arrangements are presented in the Bureau's Guide to Foreign Trade Statistics.

The foreign trade statistics are compiled in accordance with the classifications in schedule B, Statistical Classification of Domestic and Foreign Commodities Exported From the United States for exports and the Tariff Schedules of the United States Annotated (TSUSA) for imports. Publication of the statistics is on a monthly and cumulative basis in terms of both Schedule B and TSUSA. Additionally, in some reports the TSUSA data are presented in terms of a rearranged commodity classification system--Schedule A, Statistical Classification of Commodities Imported Into the United States. Both Schedule $B$ and Schedule $A$ are based on the Standard International Trade Classification (SITC).

IV. Construction Activity

U. New Residential One-Family Houses

Major types of heating fuel used for new one-family houses are published in the Annual C25, "Characteristics of New One-Family Homes." (Note: With modifications to the existing program, we can probably produce these data on a quarterly basis.)

A special tabulation was prepared showing the major types of heating fuel used in new one-family houses completed in 1971, 1972, and January through June 1973 for 29 SMSA's. (Note: This could probably be expanded to cover more SMSA's and provide semiannual data). 
NOTE: Modifications to the program could produce statistics on square feet of floor space completed and heated by the various types of fuel for new one-family houses.

New Residential Multi-Family Buildings

Major types of heating fuel used for new multi-family buildings in January 1973.

NOTE: The Bureau could provide major type of heating fuel data by number of units and by square feet of floor space for all types of residential structures at any or all of the stages of construction: starts, under construction, or completions.

C. New Nonresidential Buildings (excludes Private Utilities and Federally Constructed Buildings)

Information on major types of heating fuel used in privately owned nonresidential building projects, excluding public atilities, and for new State and local government building projects is being collected starting January 1974. The survey will provide for the tabulation of information on the square feet of floor space heated and air-conditioned by different types of fuel by major type of construction, e.g., schools, hospitals, etc., for new projects started, under construction, or completed. The Bureau should obtain a fairly comprehensive picture of fuel consumed for heating and cooling purposes. We do not have any publication plans as yet, but we hope to publish as soon as the data are considered "publishable" in the C30 Report, "Value of New Construction Put In Place."

D. Survey of Residential Alterations and Repairs - SORAR

Information on heating and air-conditioning expenditures relating to household alterations and repairs.

NOTE: This information could be expanded to obtain data on conversions from coal to oil, oil to gas, etc. However, the sample for this survey was recently reduced by about 50 percent so that expenditures must be fairly large before reliable data are obtained. Also, supplementary questions could easily be introduced to obtain other household type data.

V. Transportation Activity

A. A final hardbound Volume II has been published containing data from previously published reports for each of the 50 States, the District of Columbia and a U.S. Summary report from the 1972 Truck Inventory and Use Survey. The greatest detait is available in the public use tape. A published description of tape content is available. 
For each type of truck; data items related to characteristics of the vehicle and its use are available, particularly, annual and lifetime miles driven and type of fuel used can be tabulated by any of the other characteristics of the vehicle, its use, and location. Vehicles owned by Federal, State, and local governments are excluded.

B. The National Travel Survey data has been published in the final hardbound Volume I containing data previously published in a Spring Report (January-May 1972), Summer Report (June-September 1972) and for the full year in the report entitled "Travel During 1972." A public use tape has been prepared and a manual describing the content of the tape is available. Data items obtained in the survey and included in the record for each trip reported are identified in a published description of the computer tape program.

Estimates of amounts of non-local travel for-trips defined as "each time a person goes to a place at least 100 miles

Distribution of travel (as defined) by means of transport; distance travelled; destination of travel; person-miles of travel; and seasonality of travel.

C. Data from the 1972 Commodity Transportation Survey is published in three series of reports dealing with the movement of commodities from manufacturing establishments. The report series are Commodity Reports presenting data for about 80 3-digit commodity groups; Area Reports presenting data for each of 27 production areas and selected States and a U.S. Summary report; and Special Reports on Printing, Publishing and Allied Industries (except Newspapers and Periodicals), Traffic Patterns of Small Manufacturing Plants, and Shipper Groups.

Data is available on the intercity flow of commodities from manufacturing establishments at various commodity classification levels showing tons and ton-miles of shipments by means of transport, length of haul, weight of shipment, origin and destination. Of particular interest would be distribution of products from refineries by weight of shipment, distance shipped, and means of transport for the Petroleum Refining and Related Industries. Total movement by means of transport of commodities shipped from establishments representing the Nation's industrial universe is also shown. A computer tape for public use is being prepared. 
VI. Enterprise Statistics

A. Company level data will be compiled in the Enterprise Statistics

files for all firms engaged in minerals production, contract construction, manufacturing, wholesale and retail trades, and miscellaneous business and personal services. The information is presently being compiled for the 1972 Economic Censuses with comparable data available from the 1967 Censuses.

Data for all companies on: Number of companies and establishments, employment, payroll, and sales.

Data for Census covered companies of over 500 employees

- on capital expenditures, fixed assets, depreciation, rental payments, and total assets.

Physical location down to Census Tract level for establishments and legal form of parent company.

B. Annual data on employment and quarterly payrolls for employer firms is available from the County Business Patterns at specific economic activity (SIC) within county.

VII. Special Survey of Scientists and Engineers

A survey is being undertaken for the National Science Foundation covering scientists and engineers working on energy-related activities. Information to be collected includes the number of employees by energy source (coal, oil shale, nuclear, etc.) and by activity (extraction, conversion, etc.). Information classifying scientists and engineers by occupation and energy source will also be covered.

VIII. Agricultural Activity

The following data are available from the 1969 Census of Agriculture. Similar data will be collected in the upcoming 1974 Census.

A. Number of automobiles, trucks, tractors, and other specific farm equipment located on farms at the end of calendar year 1969.

B. Farm expenditures during calendar year 1969 for gasoline and other petroleum products in the following categories:

- Gasoline

- Diesel Fuel

- LP, Propane, and Butane Gas

- $0 i 1 s$, greases, and other petroleum products 
'IX. Government Activity

A. Quarterly

1. Summary of State and Local Tax Revenue Motor fuel sales tax revenues.

2. Construction Expenditure of State and Local Governments

a. Highways

b. Electric power systems

B. Annual

1. State Tax Collections
a. Motor fuel sales tax revenue
b. Motor vehicle registration license revenue
c. Severance tax revenue
d. Public utilities sales and gross receipts tax revenue

2. City Government Finances--national estimates based on sample and data for individual cities of over 50,000 population
a. Revenue, expenditure, and indebtedness of city- operated utilities--water supply, electric power, transit and gas supply
b. Public utility sales and gross receipts tax revenue

3. Governmental Finances--presents U.S. totals and State-byState estimates based on finance data for all States and a sample of local governments

a. Motor fuel sales and gross receipts tax revenue

b. Public utilities sales and gross receipts taxes

c. Local government-operated utility revenue, expenditure, and indebtedness--water supply, electric power, transit, and gas supply utilities

d. Highway maintenance and construction expenditures

4. Public Employment--number of employees and October payrolls for utilities operated by local governments--water supply, electric power, transit and gas supply.

C. Census of Governments--quinquennial in years ending in "2" and "7." Reports for the 1972 Census have been completed and issued. These censuses started in 1957. Each census presents data comparable to the above-mentioned finance and employment statistics for all State and local governments. 


\section{Industrial Energy Assessment Survey}

1. What are your major sources of information on energy conservation?

In house staff

Outside consultants

Trade journals (specify)

Government publications

Government:

- Federal

- State

Other (specify)

2. Is your firm a member of any trade organization which is concerned with energy conservation?

${ }_{\text {Specify }}$ Yes $\ldots$ No

3. Is someone in your plant responsible for energy conservation?

Yes No No

Name (optional)

Title

Please indicate any formal technical training this person may have

a) Degree in a technical field

b) Licensed in a technical field

c) Certificate program completion

d) Other (explain)

If "No" who would be best suited to fill this role?

Name (optional)

Title

please indicate any formal technical training this person may have?

a) Degree in a technical field 
b) Licensed in a technical field

c) Certificate program completion

d) Other (explain)

4. What is your firm currently engaged in making?

5. How many people does your firm employ?

6. Have you implemented any energy conservation programs since January of 1976 ?

Yes No

If "Yes", What types of measures were taken?

(check appropriate responses)

House Keeping

a) Room temperature adjustment

b) Lighting adjustment

c) Insulation of pipes

d) Increased maintenance of steam lines and traps

e) Weather stripping

f) Insulation (walls or roof)

g) Elimination of steam leaks

h) Other (please specify) 
Process Modification
a) Waste heat recovery
b) Flash condensate to lower pressure
c) Return steam condensate
d) Demand control
e) Replace burners
f) Control modification to reduce energy (explain)

g) Other (specify)

What: reduction in energy use do you estimate you have achieved by implementing these programs?

Was energy awareness for employees a part of your conservation program?

Yes ${ }^{\cdot} \cdot$
No

7. Have you had an energy audit conducted at your building? Yes No

If "Yes" have you implemented any energy saving measures as a result of that audit? Yes _ No (please specify what these measures are)

Winat firm conducted the encrgy audit? (optional)

8. How important do you believe coping with the cost of energy is to the success of your business?
a) No importance
b) Little importance
c) Somewhat important
d) Viery important 
9. Would you be interested in sending a representative to attend a workshop in energy conservation measures for industry?

Yes No

If "Yes" whom do we contact?

Name

Position

Office Phone No.

What energy conservation topics do you feel should be addressed in a workshop/seminar?

(specify)

$-$ 


\section{Energy Assessment Survey: Residential}

1. Number of families presently living in structure?

Number of units in structure?

Age of structure?

2. What energy conservation measures, if any, have you undertaken in your home since January of 1976 ?

(check appropriate responses)

a) Lowered thermostat in winter Y Yes 는 No

If "Yes." by how many degrees?

b) Raised thermostat for air conditioning or cooling unit in summer? Yes No

If "yes" by how many degrees?

c) Caulking and weatherstripping? Yes No

If "No" was this done prior to 1976? Yes No

d) Attic insulation? Yes No

I. If "Yes" how many inches were added?

II. What type of insulation was used?

1) cellulose 2) glass

3) foam

4) other (specify)

III. Did you install insulation yourself? Yes No

IV. How many inches of attic insulation did you have prior to January of 1976 ?

e) Wall insulation?

Yes

No

I. If yes how many inches were added?

II. What type of insulation was used?

1) cellulose

2) glass

3) foam

4) Other (specify)

III. Did you install insulation yourself? 
IV. How many inches of wall insulation did you have prior to January of 1976 ?

3. Have you utilized any alternate energy sources in your home since January of 1976 ?

Yes N No

(specify which types)

4. Has your home or building ever received an energy audit? Yes _ No

If "Yes" have you implemented any energy saving measures as a result of that audit?

Y Yes N No

(Please specify what these measures are)

Who conducted the audit?

Yourself Auditing firm (specify)

Contractor (specify)

Other (specify)

5. Would you consider weatherizing your home if reliable information about products, contractors, and instructions on installation were made available to you?

Yes $\quad$ No

6. Where do you receive most of your information about energy conservation?
a) Expo/Home shows
b) Newspaper
c) $\mathrm{T}, \mathrm{V}$.
d) Radio
e) Other (specify) 


\section{STRUCTURAL CLASSIFICATION}

STANDARD

Requires at most only normal maintenance. This category is comprised of buildings which have no defects or only surface defects in structural and/or non-structural elements.

\section{STRUCTURE REQUIRING REHABILITATION}

Does not meet criteria for being substandard.

But...has major and minor defects in primary and secondary elements that need to be corrected.

\section{STRUCTURALLY SUBSTANDARD}

1. Two (2) critical defects in primary components.

or

2. One (1) critical defect in a primary component and two major (2) defects in primary of three (3) major defects in a secondary component.

or

3. Two (2) critical defects in a secondary component and three (3) major defects in a primary or secondary $\overline{\mathrm{com}}-$ ponent.

or

4. Five (5) major defects in primary or secondary components. 
Date

Inspector

Block Parcel

Address

Construction

\section{PRIMARY COMPONENTS}

1. Foundation

Rated HI Sound and solid, fully capable of supporting the super-

(Sound) structure and containing no cracies, holes or open spaces.

Raiec \#2

(Ninor)

Basically sounc ard solid, but has cracks, small holes or open spaces correctabie by minor repair work such as tuckpoiating.

Rated \#3 Deteriorated to the degree that partial replacement of

(Najor)

materiais is necessary, and tie part to be replaced is not an integral part of the structure.

Rated $\# S$. Deteriorated to the degree that total replacement is necessary. (Critical)

Rating.

Comments

\section{Exiterior Wall Stiucture}

Rated \#1

Walls are sounả, plumb anả do not require any repair.

(Sound)

Rated \#2

Walls are basicaliy sound and plumb and require minor

(Ninor) repair but no replacement.

Rated \#3 Walls are out of plumb but otherwise sound and capable of (Major) being reinforced.

Rated \#4

(Critical)

Wails are bowed, sagging, or deteriorated to such a degïee that complete replacenent is necessary.

Rating

Comments 
- 3. Roofing Stioncture

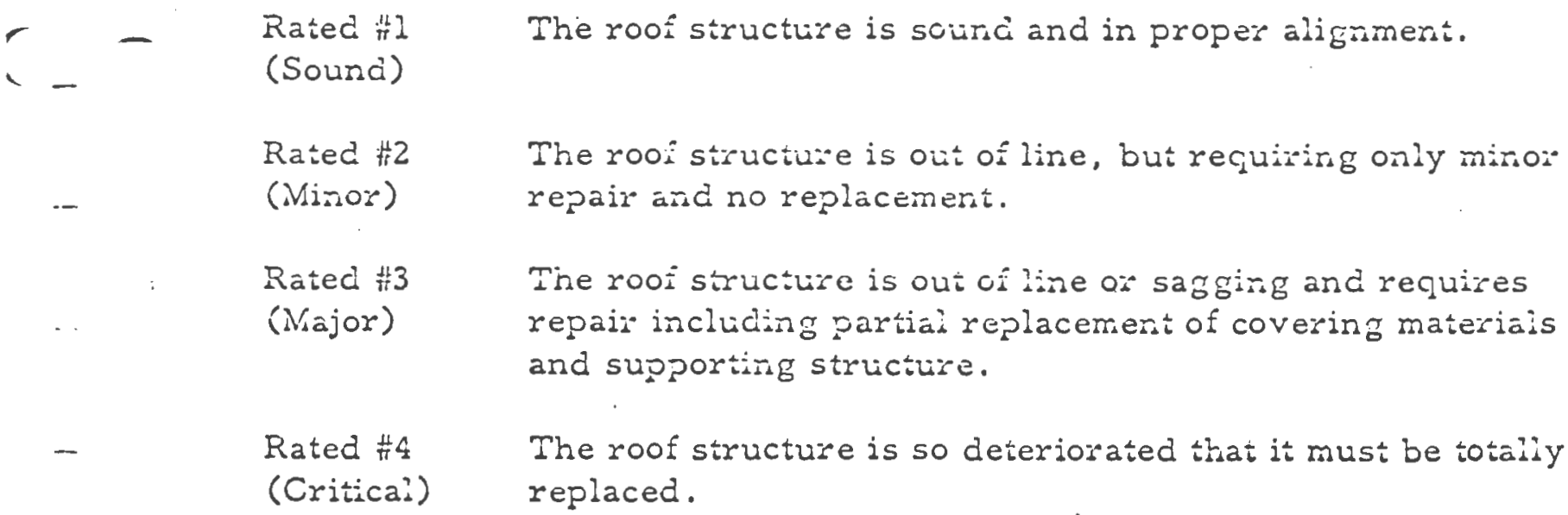

Rating

- Comments

\section{SECONDARY CONPONENTS}

4. Sicing Material

Rated \#1 The siding materials are properly applied and in a reason(Sound) ably sound condition so as to provide full protection of the occupants from the elements.

Rated \#2 The siding material is begrinring to require normal mainte(Minor) nance in order to retirrs it to its originai condition.

Rated \#3 The sidirag materials are deteriorated to the degree that ie(Major) placement of a portion is necessary to return it to its origita: condition.

Rated \#4 (Critical)

The siding rraterials have deter:iorated to the cegree that complete replacement is necessary.

Rating 


\section{Roolinis Maturial}

-ed thl The roofing materials are jroperly applied and in a reasoniwund) ably sound concition so is to provice full protection of the occupants from the elements.

Rated $\frac{11}{\pi 2}$ Ninor)

Rated $\$ 3$ (Viajor)

Rated \#4 (Critical)
The roofing material is begizring to require nowmal maintenance in order to return it to its original condition such as replacement of a few shirigies.

The roofing materials are deteriorated to the degree that replacement of a sizable porition is necessary to return it to its original condition.

The roofing materiais have deteriorated to the degree that complete replacement is necessary.

Rating

rents

6. Yard Conditions

1) trash and debris in yard

2) fences in disrepair and/or sidewalks in disrepair

3) popch sagging and having broken floor boards

4) steps and rallways unsafe and in disrepair

Rated \#1 yard is in a suitable condition

(Sound)

Rated \#2

(sipor)

yard contains 1 or 2 of the above defects

Rated \# 3

(Minor)

yard contains 3 of the above defects

Rated \#4

(Critical)

yard contains 4 of the above defects

Rating 
7. Windows and Doois

Rated thl They are solid, weathertight, and workable, and require ro (Sound) repair.

Rated ${ }^{H} 2$ They are solid, weathertight, and workable, but recuire minor (Ninor) repair suci as replacing missing putty.

Rated ${ }_{\pi} 3$ They are sagging, not completely workable or weathertigtat and (Major) require some replacement of broken panes, frames, sills, and sastes.

Rated \#ts They have deteriorated to such a degree tisat total replacement (Critical) is necessary.

-Rating

Comments

8. Outstructure (garage, shed, etc.)

Rated \#1 structure is plumb, roof adequate, exterior (Sound) has adequate siding, etc.

Rated \#2 structure has minor defects in roof, siding (minor) foundation.

Rated \#3 structure has major defects in roof, siding (Major) and foundation.

Rated \#4 structure has critical defects in roof, si(Critical) ding, and foundation

Rating

Comments 
Building or Lots Having an Acverse Effect on Surrounding Area

$\because \quad$ Inacequate street layout

$\therefore$ Incompatible uses or land use relationships

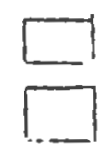

$$
\text { Explain }
$$

$\therefore \quad$ Overcrowding of buildings on land

Explain

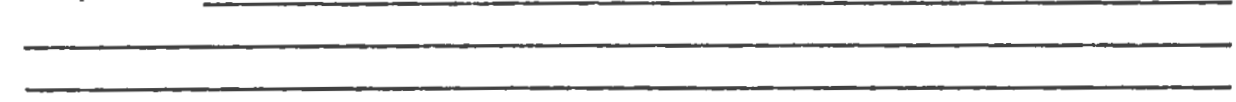

4. Ixcessive dwelling unit censity

$$
\text { Txpiain }
$$

5. josolete buildings not suitable for improvement or conversion

$$
\text { Txplain }
$$

2. Zther hazards to hoalth, saiety, and Eeneral weIl being of the community

a. Building or Iot containing trash and debris

b. Lack of maintenance; unsighty appearance

c. other

7. Other 
TXTERTYT STISTEY

CTISTS

DERARE COMPOINITES

i. Founcation

Lating

Cominents

2. Fxterior thale Dtructure

Comments

Rating

2. Eoofine Etructure

Rating

Comments

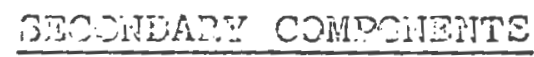

4. Sicine Material

Comments

Iating

5. Poofing llaterial

- Comments

Rating.

6. Yarc Condition

Comments

nating

7. Mincous and Doors

Conments

Fating

3. cutstructure

Tiating

Comments

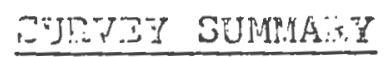

f. vimary Components

Seconcary Components

Minor Ijefects

Majo: Sefects

Minor Defects

Critical Defects

ilajor iefects

Critical Defects

3. Tetjing:

(i) [ Structura 1 y substanciars to a degree warraning clearaice

(?) I Jesicient

(3) [ Ltanciard recuiring normal maintenance 


\section{ATTITUCE SURVEI}

Age

Kenter Owror Occupant

Farily siza

A. NEICHBOLIIOOD TRENDS

1. Vl:ere is your neighborhood (Draw on map)?

2. Why do you live here?

3. Do you like your house or apartment?

4. How long have yo's Iiv iُ here?

5. Where "ra!s your last residence?

6. What chringes have occirred in the neifiborhoods since jou rave been hera?

a. Housing?

b. Crime or Law Eniorcement?

c. Ethnic Composition

d. other

3. SFHV ICES

1. Where cio you go sliopping?

2. Where do your childran play?

how are the facilities?

3. Whore do your clilidren go to school? 
IICW io $j$ iu find tile ejlicational servicais?

4. How often is your garbage piclsed up?

5. What social scivice crganizations serve jou? (YMCA, hétl.ta center, farily counseling)?

Do you socialize inside or outside tro aren? Where?

Are frou a meiber cî any groups or erganization: in the area?

\section{EIVIRTNMELT}

1. Do you reel safe on tha streat?

2. Are the poIice visible?

Do trey do a gosd job?

3. How many frierds do ysu have in the neirhbo:isod?

4. Is tlits a good naightorhood to raise a family? Why or wiig not?

5. What is the hest feature of your neightorloos?

6. Whri is the woret reaturs of the neightorhocd?

D. NEEDS

If you were given ove million dollars to improve your neigianalood, pihat would you do with it? 


\section{ATTITUC: SURVE?}

Age

Renter

Owror Occupant

Far:ily Siza

A. NEICHBOIJOOD TRENDS

1. Mliare is your neighborhood (Draw on map)?

2. Why do you live here?

3. Do you like your house or apartment?

4. How long have yo"d iiv si here?

5. Where wa: your last restdence?

6. What chr.nges have occlirred in the neigiborhoods since $5=4$ have been hora?

a. Housing?

b. Crime or Law Eniorcement?

c. Ethnic Composition

d. other

3. SERV ICES

1. Where io you go sliopring?

2. Where do your children play?

How ane the facilities?

3. Where do yoir clijldren go to schoo?? 
IIciv lo jou find tie ejlicational servicai?

4. How often is your sarbare piclsed up?

5. What social scivice crganfzatious serve you? (Milis, healta center, farily counselling)?

Do you socialize inside or outside the area? Where?

Are you a menber of uny groups or regranizations in the area?

C. EIVIRONMENT

1. Do you feel safe on the streai?

2. Are the poitice visible?

Do they do a gosd job?

3. Fow many frierds do you have in the reichbozisod?

4. Is tliis a good reightorlood to raise a family? Why or wirity not?

5. What is the hest feature of your notghrur!sosd?

6. Whric is the woist isaturs of the lleightorhocd?

D. NEEDS

I $\hat{i}$ you were given ove million dollars to improve your neigitarliood, pinat rould you do with it? 
APPETDIX D

1. "GENERAI HIGHWIAY AND STREET STANDARDS"

2. "HIGHYAY CLASDIFICATION"

3. "Neighborhood Concept

4. "Costs of Sprawl" Rppresentative Devleopment Patterns 


\begin{tabular}{|c|c|c|c|c|c|c|c|}
\hline Type of Facility & $\begin{array}{c}\text { Function and } \\
\text { Design Features }\end{array}$ & Spacing & R.o.w. & $\begin{array}{l}\text { Widths } \\
\text { Pavement }\end{array}$ & $\begin{array}{c}\text { Desirable } \\
\text { Maximum } \\
\text { Grades }\end{array}$ & Speed & Other Features \\
\hline Freeways & $\begin{array}{l}\text { Provide regional and metropolitan } \\
\text { continuity and unity. Limited ac- } \\
\text { cess; no grade crossings; no traffic } \\
\text { stops. }\end{array}$ & $\begin{array}{l}\text { Variable; related to } \\
\text { regional pattern of } \\
\text { population and } \\
\text { industrial centers }\end{array}$ & $200-300^{\prime}$ & $\begin{array}{l}\text { Varies; } 12^{\prime} \text { per lane; } \\
8-10^{\prime} \text { shoulders } \\
\text { both sides of each } \\
\text { roadway; } 8 \text { ' }-60^{\prime} \\
\text { median strip. }\end{array}$ & $3 \%$ & $60 \mathrm{mph}$ & $\begin{array}{l}\text { Depressed, at grade, or elevated. } \\
\text { Preferably depressed, through ur. } \\
\text { ban areas. Require intensive land- } \\
\text { scaping, service roads, or adequate } \\
\text { rear lot building set-back lines } \\
\left(75^{\prime}\right) \text { where service roads are not } \\
\text { provided. }\end{array}$ \\
\hline $\begin{array}{l}\text { Major Roads } \\
\text { (Major Arterials) }\end{array}$ & $\begin{array}{l}\text { Provide unity throughout contigu- } \\
\text { ous urban area. Usually form } \\
\text { boundaries for neighborhoods. } \\
\text { Minor access control; channelized } \\
\text { intersections; parking generally } \\
\text { prohibited. }\end{array}$ & $11 / 2$ to 2 miles & $120-150^{\prime}$ & $\begin{array}{l}84^{\prime} \text { maximum } \\
\text { for } 4 \text { lanes, } \\
\text { parking and } \\
\text { median strip. }\end{array}$ & $4 \%$ & $35-45 \mathrm{mph}$ & $\begin{array}{l}\text { Require } 5^{\prime} \text { wide detached side- } \\
\text { walks in urban areas, planting } \\
\text { strips }\left(5^{\prime}-10^{\prime} \text { wide or more) and }\right. \\
\text { adequate building set-back lines } \\
\left(30^{\prime}\right) \text { for buildings fronting on } \\
\text { street; } 60^{\prime} \text { for buildings backing } \\
\text { on street. }\end{array}$ \\
\hline $\begin{array}{l}\text { Secondary Roads } \\
\text { (Minor Arterials) }\end{array}$ & $\begin{array}{l}\text { Main feeder streets. Signals where } \\
\text { needed; stop signs on side streets. } \\
\text { Occasionally form boundaries for } \\
\text { neighborhoods. }\end{array}$ & $3 / 4$ to 1 mile & $80^{\prime}$ & $60^{\circ}$ & $5 \%$ & $35-40 \mathrm{mph}$ & $\begin{array}{l}\text { Require } 5^{\prime} \text { wide detached side- } \\
\text { walks, planting strips between side- } \\
\text { walks and curb } 5^{\prime} \text { to } 10^{\prime} \text { or more, } \\
\text { and adequate building set-back } \\
\text { lines }\left(30^{\circ}\right) \text {. }\end{array}$ \\
\hline Collector Streets & $\begin{array}{l}\text { Main interior streets. Stop signs on } \\
\text { side streets. }\end{array}$ & $1 / 4$ to $1 / 2$ mile & $64^{\prime}$ & $\begin{array}{l}44^{\prime}\left(2-12^{\prime} \text { traffic }\right. \\
\text { lanes; } 2-10^{\prime} \\
\text { parking lanes })\end{array}$ & $5 \%$ & $30 \mathrm{mph}$ & $\begin{array}{l}\text { Require at least } 4^{\prime} \text { wide detached } \\
\text { sidewalks; vertical curbs; planting } \\
\text { strips are desirable; building set- } \\
\text { back lines } 30^{\prime} \text { from right of way. }\end{array}$ \\
\hline Local Streets & $\begin{array}{l}\text { Local service streets. Non-con- } \\
\text { ducive to through traffic. }\end{array}$ & at blocks & $50^{\prime}$ & $\begin{array}{l}36^{\prime} \text { where street } \\
\text { parking is } \\
\text { permitted. }\end{array}$ & $6 \%$ & $25 \mathrm{mph}$ & $\begin{array}{l}\text { Sidewalks at least } 4^{\prime} \text { in width for } \\
\text { densities greater than } 1 \text { d.u./acre, } \\
\text { and curbs and gutters. }\end{array}$ \\
\hline Cul-de-sac & $\begin{array}{l}\text { Street open at only one end, with } \\
\text { provision for a turn-around at the } \\
\text { other. }\end{array}$ & only wherever practical & $\begin{array}{c}50^{\prime} \\
\quad\left(90^{\prime} \text { dia. }\right. \\
\text { turn-around) }\end{array}$ & $\begin{array}{l}30^{\prime}-36^{\prime}\left(75^{\prime}\right. \\
\text { turn-around) }\end{array}$ & $5 \%$ & & $\begin{array}{l}\text { Should not have a length greater } \\
\text { than } 500 \text { feet. }\end{array}$ \\
\hline
\end{tabular}




\section{HIGHWAY CI SIFICATION}

Highway systems are grouped into a number of different classifications for administrative, planning, and design purposes. The Federal Aid financing system, state-county-city's administrative systems, and commercialindustrial-residential-recreational systems are examples of the variety of highway classifications.

In the most basic classification system for design work, highways and streets are grouped into: (1) interstate, primary (excluding interstate), secondary, and tertiary road classes in rural areas, and (2) expressway, arterial, collector, and local road classes in urban areas. These classifications usually carry with them a set of suggested minimum design standards which are in keeping with the importance of the system and are governed by the specific transportation services the system is to perform. The principal consideration for designating roads into systems are the travel desires of the public, land-access requirements based on existing and future land use, and continuity of the system. Four basic purposes of urban street systems have been suggested:

1. Expressway system (including freeways and parkways) - providing for expeditious movement of large volumes of through traffic between areas and across the city, and not intended to provide land-access service.

2. Major arterial system-providing for the through traffic movement between areas and across the city, and direct access to abutting property; subject to necessary control of entrances, exists, and curb use.

3. Collect or street system-providing for traffic movement between major arterials and local streets, and direct access to abutting property.

4. Local street system-providing for direct access to abutting land, and for local traffic movements.

These basic purposes of city street systems are similar to those of rural interstate, primary, secondary, and tertiary highways, respectively, so far as the various degrees of accommodation of through traffic and land access is concerned. However, regional as well as national highway transportation requirements must be met by rural highways. The Tables compare the overall criteria of urban street and rural highway classifications.

The principles and elements of geometric design for both urban and rural facilities are generally the same. However, to meet urban and rural traffic demands, design details are often varied because speeds, traffic composition, lengths and purposes of trips, etc., are not the same.

SOURCE: Standards for Street Faritilies and Services, Procedure Munual 7A. National Commistee on Urban Tronsporiation, Public Auminisiration Service. Chicago, 1958. p. 11

\section{URBAN STREET CLASSIFICATION CRITERIA}

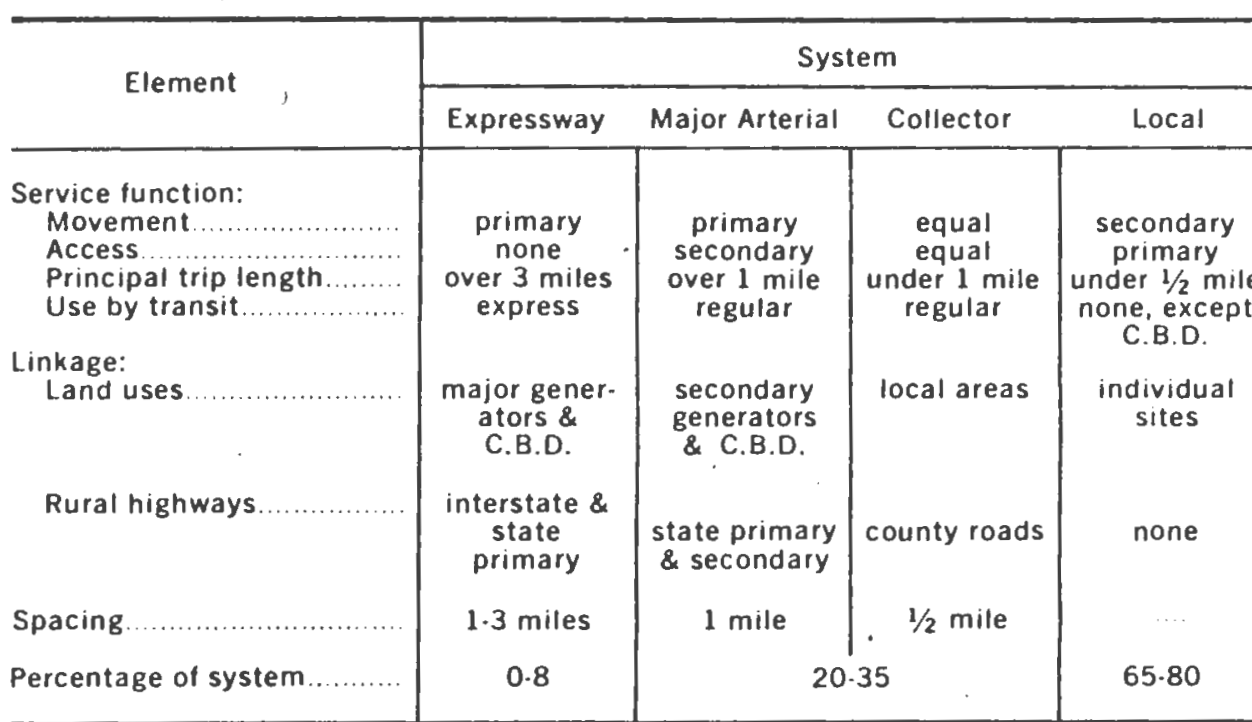

\section{RURAL ROAD CLASSIFICATION CRITERIA*}

\begin{tabular}{|c|c|c|c|c|}
\hline \multirow{2}{*}{ Element } & \multicolumn{4}{|c|}{ System } \\
\hline & interstate & Primary & Secondary & Tertiary \\
\hline $\begin{array}{l}\text { Service function: } \\
\text { Movement......... } \\
\text { Access................ }\end{array}$ & $\begin{array}{c}\text { primary. } \\
\text { controlled }\end{array}$ & $\begin{array}{l}\text { primary } \\
\text { secondary }\end{array}$ & $\begin{array}{l}\text { equal } \\
\text { equal }\end{array}$ & $\begin{array}{c}\text { secondary } \\
\text { primary }\end{array}$ \\
\hline $\begin{array}{l}\text { Linkage to: } \\
\text { Geographic..... }\end{array}$ & major cities & smaller cities & $\begin{array}{c}\text { smaller cities } \\
\& \text { regions }\end{array}$ & $\begin{array}{l}\text { farm-to- } \\
\text { market }\end{array}$ \\
\hline Urban streets.. & expressways & $\begin{array}{c}\text { expressways \& } \\
\text { major } \\
\text { arterials }\end{array}$ & $\begin{array}{c}\text { major arteriais } \\
\& \text { collectors }\end{array}$ & $\begin{array}{l}\text { collectors } \\
\text { \& local }\end{array}$ \\
\hline Percentage of system.......... & 2 & 17 & 10 & 71 \\
\hline
\end{tabular}

*Includes surfaced roads only. 
In terms of the minimum desirable number of lanes, a single lane on a Class 1 bikeway is not particularly effective since it doesn't allow passing without leaving the bikeway. As a recommended minimum on Class I bikeways, two lanes should thus be provided to allow a passing lane capability.

On Class II bikeways the minimum number of lanes that should be provided depends upon where on the street the bikeway is incorporated.

In Class II bikeways additional clearance should be allowed for "dynamic" obstructions. The most obvious example of this is when the bikeway is located adjacent to a parking lane. Since opening doors constitute a dynamic hazard to cyclists, an additional clearance for the car door should be allowed if adequate clearance is not provided in the parking lane and high parking density and turnover exist. Similarly the proximity of the bikeway to traffic lanes (and the speed, volume and mix of passing traffic) may require additional clearance if barriers are not provided and if the traffic lane is not wide enough to provide the necessary spatial separation.

TABLE 1 Minimum Effective Width for Class I and Class II Bikeways as a Function of Number of Bikeway Lanes

\begin{tabular}{|c||c|c|}
\hline \multicolumn{1}{|c||}{$\begin{array}{c}\text { Mumber } \\
\text { of } \\
\text { Lanes } \\
\text { (One Way) }\end{array}$} & German Specifications & $\begin{array}{l}\text { Modified German Specifications } \\
\text { Based upon a Comfortable } \\
\text { Maneuvering Allowance at a } \\
10 \text { mph Design Speed }\end{array}$ \\
\hline 1 & $3.3(1 \mathrm{~m})$ & 3.3 \\
2 & $5.3(1.6 \mathrm{~m})$ & 6.4 \\
3 & $8.5(2.6 \mathrm{~m})$ & 10.9 \\
$11.8(3.6 \mathrm{~m})$ & 15.3 \\
\hline
\end{tabular}

\section{GRADE}

Cyclist characteristics (age, weight, conditioning, oxygen uptake, etc.), bicycle characteristics (gear ratios, type of cycle, tires, weight, etc.), wind velocity, air resistance, and road surface are major determinants of maximum acceptable bikeway grades and the length such grades should be in effect.

Source (1) recommends a $4-5 \%$ grade for one-speed cycles with a $9-10 \%$ maximum on "short" runs.

\section{VOLUME CRITERIA FOR SEPARATED BIKEWAYS}

Internationally, separated bikeways (Class I, II) have generally been recommended where:

1. Significant regular bicycle traffic exists, and/or

2. Significant future bicycle traffic is forecast, and/or

3. Significant motor vehicle traffic is present on the roadway. 


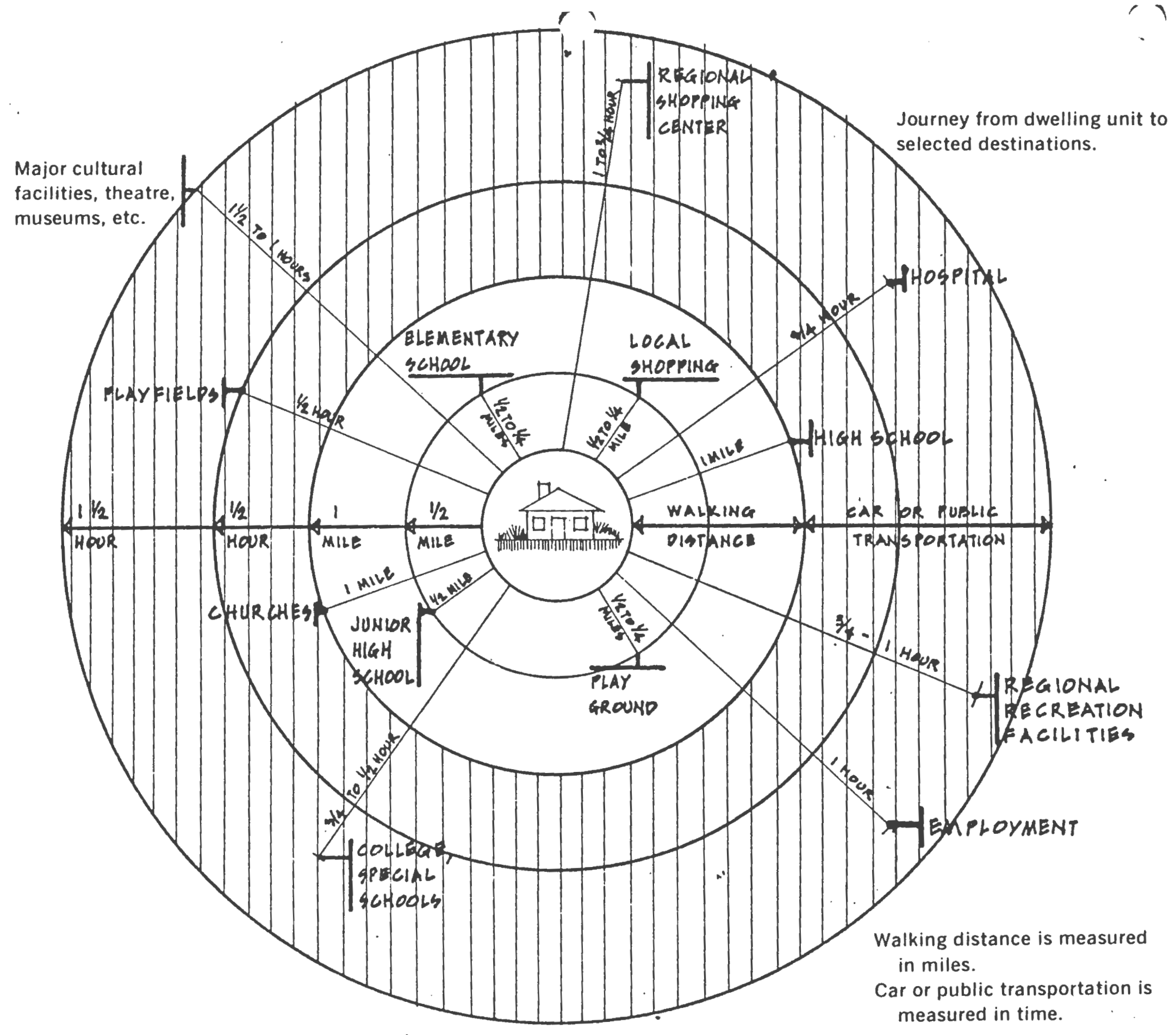


FIGURE A

REPRESENTATIYE DEVELOPMENT PATTERNS

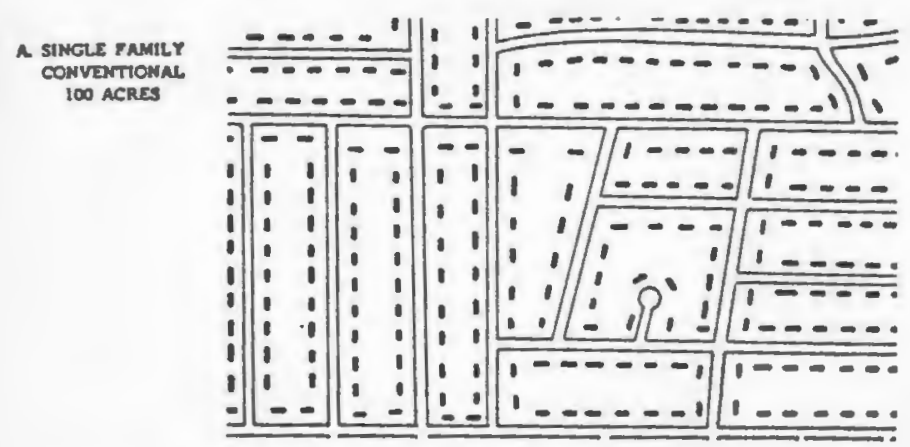

- sange ranar CUSTERED 100 MCRES

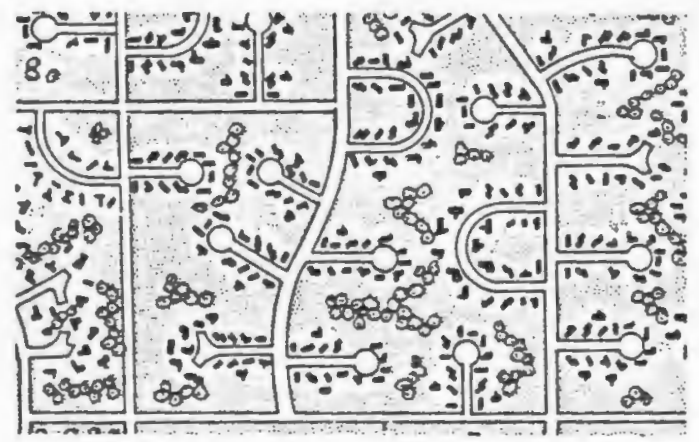

C TOWNHOUSEs 100 ACRES

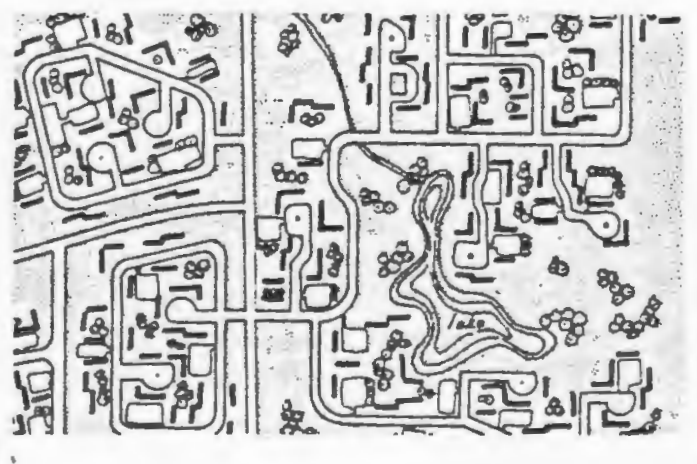

D. WALK-US APARTMEMTS 100 ACRES

- HICH RUSE PARTMENTS 100 ACRES
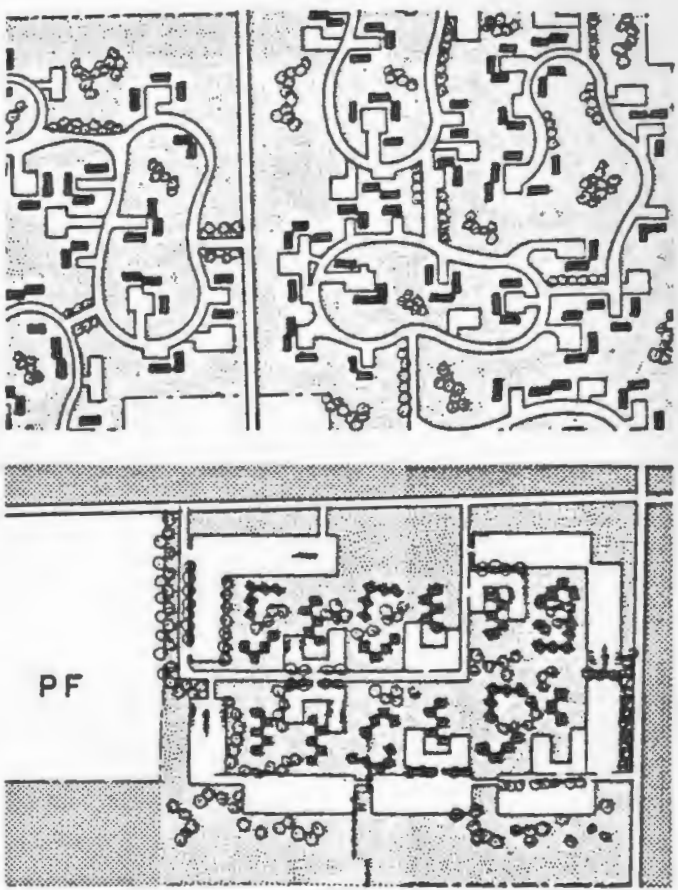

HOUSTNC MaX 20\% EACH A-E) 100 ACRES

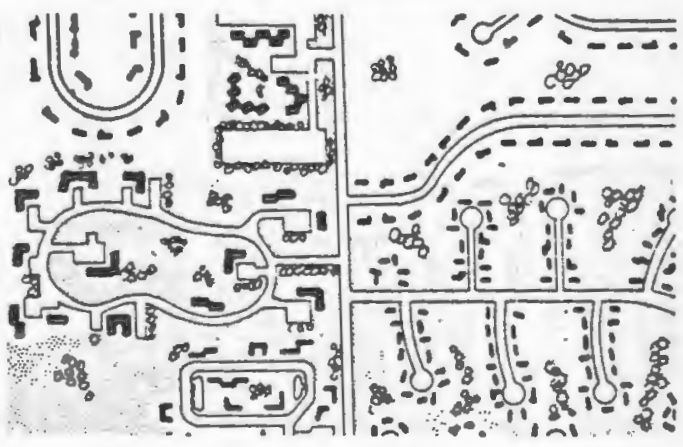

MEICHEORHOOD PROTOTYPES - LECDND

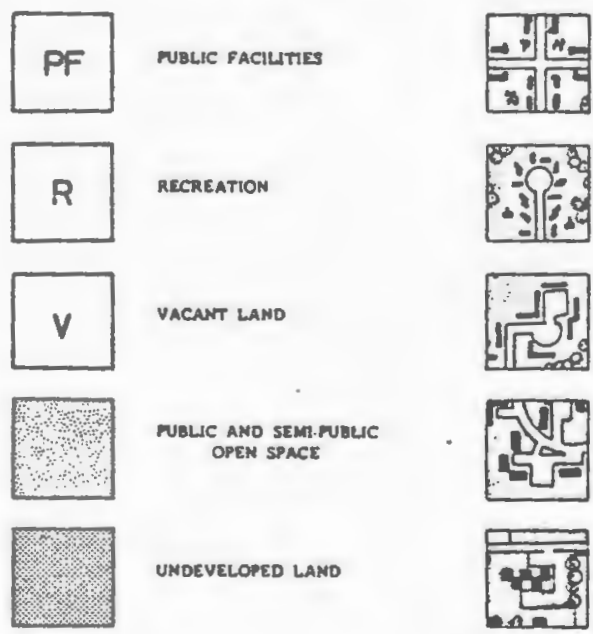

SINGLE PAMILY CONVENTIONAL.

SINCLE FAMILY CLUSTERED

TOWHHOUSES CLUSTERED

WALK-UP APARTMEMTS

MICH RISE ADARTMENTS 